\title{
LEGITIMIDADE E CRISE DO SERVIÇO SOCIAL \\ Um Ensaio de Interpretação Sociológica da Profissão.
}

Marilda Villela Jamamoto

Orientador: Prof. ${ }^{\circ}$ Dr. ORIOWALDO QUEDA

Dissertação apresentada à Escola Superior de Agricultura "Luiz de Queiroz", da Universidade de São Paulo, para obtenção do título de Mestre em Sociologia Rural.

PIRACICABA

Estado de São Paulo - Brasil

Abril, 1982 
Aos meus pais, Moysés e Hilda, Ao companheiro Jorge, Ao pequenino André Toshio, dedico este trabalho.

A vocês, com carinho, o meu reconhecimento. 


\section{AGRADEC IMENTOS}

Gostaria de registrar meus agradecimentos à pessoas e entidades que colaboraram para a realização deste trabalho:

- ao Prof. Dr. Oriowaldo Queda, amigo e orien tador, pelo inestimävel apoio intelectual, pela disponibilida de, estimulos e confiança demonstrados nesses anos de cönvi vência;

- ao economista Raul de Carvalho, colega de pesquisa, que numa demonstração de verdadeira amizade, partí lhou comigo de toda a trajetória desta dissertação;

- à direção do Centro Latino-Americano de Tra balho Social - CELATS -, na pessoa de Leila Lima Santos, pelo apoio e compreensão proporcionados;

: - à Diretoria da Faculdade de Serviço Social da PUC-SP, atravês da Prof. Maria Carmelita Yasbeck e aos co legas do Departamento de Fundamentos do Serviço Social, repre sentados pela Prof. Raquel Raichelis, que propiciaram condições para que esta dissertação fosse concluída;

- ao Prof. Dr. Octävio Ianni, pelos incentivos e pelo apoio efetivo;

- ao amigo e Prof. Dr. José de Souza Martins, a quem devo importante etapa de minha formação profissional;

- ao amigo e Prof. Josê Albertino Rosārio Rodrigues pela contribuição decisiva em minha formação sociológica;

- à sociöloga e amiga Maria Berenice Lacroix pelo acompanhamento das discussões e pela leitura parcial dos originais;

- ao colega José Paulo Netto pelas sugestões apresentadas; 
- aos professores e colegas do curso de Socio logia Rural da ESALQ/USP, que contribuiram para a minha forma ção intelectual;

- aos alunos da Faculdade de Serviço Social da PUC-SP que representam um desafio permanente para o repensar da profissão;

- aos pesquisadores Manuel Manrique Castro e Alejandrino Maguiña Larco pelas calorosas discussões, amizade e companheirismo;

- à Fundação Ford e ao Prof. Joaquim Josë de Camargo Engler, que viabilizaram um apoio financeiro durante um período do curso de pós-graduação;

- ao Jorge Iamamoto, pelo apoio permanente, pe 10 respeito e incentivos constantes ao meu desempenho profissional, dividindo as alegrias e dificuldades na realização deste trabalho;

- às colegas Yara Spadini Vicini, Maria Bereni ce Godinho Delgado, Luzia Fătima Baierl Lippi, Rosalina de Santa Cruz Leite, Sandra Amêndola Barbosa Lima e Rachel Rai chelis pela colaboração na revisão final dos originais desta dissertação;

- à Arlene Ghiraldelli Forli que realizou os serviços datilogräficos;

Finalmente, deve ser afirmado que as pessoas e entidades supra-citadas não têm qualquer responsabilidade so bre as opiniões emitidas e possíveis falhas deste ensaio.

Piracicaba, abril de 1982 . 
INDICE

Pägina

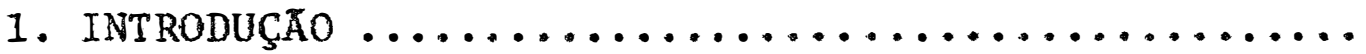

2. UMA CONCEPÇAOO TEORICA DA REPRODUÇATO DAS RELAÇOES SO

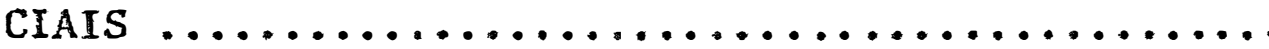

2.1. A Produção Capitalista é Produção e Reprodução das Relações Sociais .................. 11

2.2. 0 Capital como Relação Social ............. 14

2.2.1. O Capital e a Forma Mercadoria ....... 14

2.2.2. A Transformação da Mercadoria em Capí

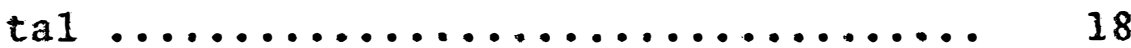

2.3. As Relações Mistificadas e o Ciclo do Capital. 30

2.4. A Reprodução do Capital e a Totalidade da Vida

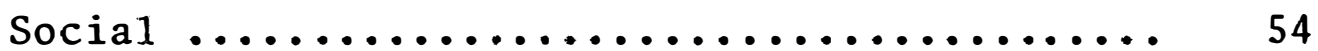

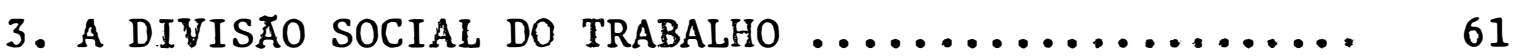

3.1. Fundamentos da Divisão Social do Trabalho .... 63

3.2. A Divisão Manufatureira do Trabalho ......... 69

3.3. A Divisão do Trabalho na Grande Indústria.... 77

4. O SERVIÇO SOCIAL NO PROCESSO DE REPRODUÇAOO DAS RELA ÇOES SOCIAIS ....................... 89

4.1. Perspectiva de Anälise ................ 89

4.2. A Intervenção do Agente Profissional nas Rela ções Sociais ..................... 96

4.3. O Significado dos Serviços Sociais ......... 111

4.4. Relações Sociais e Serviço Social .......... 116

4.4.1. Serviço Social e Reprodução da Força de Trabatho .................... 121

4.4.2. Serviço Social e Reprodução do Controle e da Ideologia Dominante ........... 130

5. LEGITIMAÇÃO E CRISE DO SERVIÇO SOCIAL ........... 150

5.1. Problematização do Tema ................... 150

5.2. A "Questão Social" no Capitalismo Monopolista. 158 
Päginà

5.3. Assistente Social: O Profissional da Coerção e

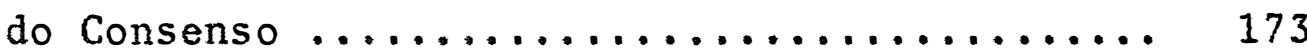

5.4. O Serviço Social Face à "Questão Social" no Cą pitalismo Monopolista .................. 192

5.4.1. A Herança Conservadora do Serviço So cial e Sua Atualização ............. 194

5.4.2. A Ruptura com a Herança Conservadora .. 217

LITERATURA CITADA

224 


$$
\begin{array}{llllll}
R & E & S & U & M & 0
\end{array}
$$

LEGITIMIDADE E CRISE DO SERVIÇO SOCIAL. Um Ensaio de Interpretação Sociolögica da Profissäo.

Marilda Villela Iamamoto

Orientador: Prof. Dr. Oriowaldo Queda

A presente dissertação apresenta uma anālise sociolögica da profissão de Serviço Social frente às relações sociais, referenciada ao contexto de aprofundamento do capita lismo na sociedade brasileira. Objetiva explicitar o significado social dessa instituição e das práticas desenvolvidas em seu âmbito por agentes especialmente qualificados: os Assis tentes Sociais.

Consiste em um ensaio teärico, fruto de pesqui sa bibliogräfica. Expõe os fundamentos analíticos do processo de reprodução das relações sociais e da divisão do trabalho na sociedade e no interior da produção, a partir de textos clâssicos marxistas. Situa o Serviço Social nesse processo, como uma atividade auxiliar e subsidiäria no exercício do con trole social e da difusão da ideologia dominante junto à clas se trabalhadora. Através da prestação dos serviços sociais, que concretizam politicas sociais do Estado, contribui, tam bém, para a reprodução da força de trabalho, participando, ainda, da reprodução das contradições básicas que caracter zam a organização social vigente. Finalmente, problematiza a legitimação e crise do Serviço Social na sociedade brasileira, nas três ültimas décadas, tendo por pano de fundo o signi ficado da questão social no capitalismo monopolista. Expõe as respostas dadas pela categoria profissional às novas características da demanda: a atualização da herança conservadora do Serviço Social e a busca de ruptura com a mesma. 
vii

S U M M A R Y

LEGITIMACY AND CRISIS OF SOCIAL WORK.

A Sociological Interpretation Essay of the Profession.

Marilda Villela Iamamoto

Guidance: Prof. Dr. Oriowaldo Queda

The actual dissertation is a sociological

analysis of the Social Work as a professional area and social relations, based on the development of the capitalism in the Brazilian Society. It pretends to reveal the social meaning of this institution and the practice developed by specially qualified agents: the Social Workers.

It consists in a theoretical study, resulting of a bibliografical research. It exposes the analitc bases of the reproduction process of social relations and the workdivision in society and inside the production, based on marxist classic texts. It places the Social Work in this process, as an auxiliary and subsidiary activity that exercises the social control and the diffusion of dominant ideology, over the working classes. By renderind social services, that realize the social politics of the State, it also contributes to the working-power and the reproduction of basic contraditions which characterize the actual social organization.

At last, it puts in doubt the legitimacy and crisis of Social Work in Brazilian Society, in the last three decades, having as background the meaning of social matter in monopolist capitalism. It exposes the answers of the professional category to the new characteristics of the discussion: to bring up-to-date the conservative inheritance of Social Work and to break out with it. 
1. INTRODUÇÃO

A presente dissertação não é apenas um ensaio teórico descompromissado e alheio à vida da autora. Encontrase enraizado em sua trajetória profissional, constituindo uma anâlise teórica sobre uma vivência prâtica da profissão, acumulada durante vărios anos, seja atravës de atividades de cam po, de docência e pesquisa. Neste trabalho sujeito e objeto de pesquisa se confundem num só agente com os riscos e potencialidades dai derivados.

Este ensaio não se configura, portanto, como um trabalho meramente acadêmico, cujas indagações e cujos fins se circunscrevam nos limites da Universidade. Passa por ela, como uma oportunidade de sistematização e de um distan ciamento crítico do jă vivido no cotidiano da vida profissional. Essa passagem, acoplada a uma reflexão sobre o Serviço Social, deu-se na busca de um suporte científico a nível das Ciências Sociais na tarefa de desvendar e compreender uma dimensão de vida: a prätica profissional dos Assistentes Sociais na sociedade capitalista.

Assim é que na seleção do tema da dissertação passou-se do Cooperativismo ao Serviço Social, priorizando, em detrimento de uma reflexão sobre a sociedade agrâria, uma interpretação sociolôgica desse exercîcio profissional em 
suas conexões com a produção e reprodução das relações sociais na formação social vigente na sociedade brasileira.

Este texto, de cunho teörico, tem por suporte além da vivência profissional, um trabalho sistemático de pes quisa documental, levado a efeito sob os auspicios do Centro Latino-Americano de Trabalho Social - CELATS, durante 0 ano de 1978, como parte de um projeto mais amplo sobre a "História do Serviço Social na América Latina". (1)

Preliminarmente, impõem-se algumas considerações sobre a perspectiva de anälise que orientou a abordagem do objeto de estudo: o Serviço Social como profissão referen ciada ao contexto de aprofundamento do capitalismo na socieda de brasileira. Através desse estudo procurou-se desvendar o significado social dessa instituição e das prāticas desenvol vidas em seu âmbito, por agentes especialmente qualificados: os Assistentes Sociais. A anālise sociológica hessa perspectí va implicou o esforço de inserir a profissão no processo de reprodução das relações sociais.

Afirmar que a instituição Serviço Social é pro duto ou "reflexo" da realidade social mais abrangente, expres sa apenas um ângulo da questão, se considerado isoladamente. Por outro lado, reduzir a ancilise dos elementos constitutivos "internos" -- que, supostamente, peculiarizam à profissão um perfil especifico: seu objeto, objetivos, procedimentos e têc

(1) O projetó dessa pesquisa foi, parcialmente, publicado. Ver: M. V. Iamanoto e M.C. Manrique. "Hacia el Es tudio de la História del Trabajo Social en Ia Amörica Latina". In: Acciön Critica n 5, abr. de 1979, Celats-Alaets, Lima, p. 53-73. A pesquisa sobre a histöria do Serviço So cial no Brasil foi coordenada pela autora e efetuada conjuntamente com Raul de Carvalho. Ver, M.V. Iamamoto e R. de Carvalho. 'Relatório Final da Pesquisa sobre a His tōria do Serviço Social no Brasil". São Paulo, 1979 (não publicado). Outros resultados parciais daquele projeto mais am plo são o livro de autoria de A.L.Maguiña. Desarrollo Capitalista y Trabā jo Social. Peru 1896-1979. Lima, Celats, 1979 e o artígo de R. de Carva1ho. "Modernos Agentes da Justiça e da Caridade". In: Serviço Social e Soetiedade $\pi^{0} 2$, ano I, mar. 1980. São Paulo, Cortez Ed., p. 43-71. 
nicas de atuação, etc. -- significa extrair, artificialmente, - Serviço Social das condições e relações sociais que the dão inteligibilidade e nas quais se torna possível e necessärio. Significa privilegiar a visão focalista e a histórica que per meia muitas das análises institucionais. A tentativa de superação dessas orientações metodológicas implicou considerar que a apreensâo do significado histórico da profissão só é desven dada em sua inserção na sociedade, pois ela se afirma como instituição peculiar na e a partir da divisão social do traba 1ho. Como a profissão sổ existe em condições e relações sociais historicamente determinadas, $\vec{e}$ a partir da compreensão destas determinações histōricas que se poderā alcançar o significado social desse tipo de especialização do trabalho cole tivo (social), mais alêm da aparência em que se apresenta em seu próprio discurso, e, ao mesmo tempo, procurar detectar co mo vem contribuindo, de maneira peculiar, para a continuidade contraditória das relações sociais, ou seja, do conjunto da sociedade. ( $\underline{2})$

Não se tem pretensão de, atravês deste trabalho, chegar a uma demonstração cabal de como o Serviço Social vem contribuindo, em sua evolução, para a reprodução das rela ções sociais. O que se supõe viável é explicitar as ferramen tas teóricas que possibilitam trabalhar sob esta ótica de ana lise e situä-10 nesse processo.

(2) "Mostrar que una instituição "reflete". ou expressa uma realidade mais profunda e elevada, guer dizer, ${ }_{2}$ inconsciente ou a histôria, a sociedade ou o Estado burgues, o economico ou o social, é uma coisa: mostrar como ela contribui nara a nroducão e renroducão das relacões sociais è outra coisa." H. Lefebvre. "Es trutura social: A Reproduçāo das Re laçoes Sociais". In: M.M. Foracchi e J.S. Martins. Sociologia e sociedade (Leituras de introdução à Sociologia). Rio de Janeiro, Livros Técni cos e Cientificos, 1977. p. 288-9. Grifos nossos. 
Esta $\hat{e}$ uma linha de anâlise que não encontra suporte na bibliografia especializada do Serviço Social, implicando, portanto, a necessidade de recuperar a teoria e o método de anâlise de autores clässicos. Nesse sentido procu ra-se, no decorrer do estudo, explicitar o desenvolvimento da lógica que preside a concepção relativa à reprodução das rela ções sociais. Mais do que uma exposição, em forma didática, de categorias fundamentais da anâlise marxista, representa um esforço de sistematização de uma leitura dos clássicos : que busca recuperar a dimensão da totalidade dessa teoria e método, vistos de forma indissociâvel. Acentua-se, como diretriz da própria elaboração do texto, o empenho em explicitar a articulação bâsica e contraditória entre a essência das relações sociais e sua manifestação através de formas mistificado ras, mas necessârias à expressão dos fenômenos sociais: ambas criadas e recriadas no próprio processo da vida social. Cabe situar que o uso intenso de citações -- particularmente nos dois capítulos subsequentes -- teve por objetivo garantir rigor conceitual, funcionando, assim, como um roteiro de leitura das fontes utilizadas. A exposição do processo de reprodução das relações sociais e as considerações sobre a divisão do trabalho apresentam, necessariamente, maior nível de abstração, sendo, porêm, indispensáveis dentro da estratêgia teó rico-metodológica adotada para uma reflexão do Serviço Social face às relações sociais vigentes.

Essas reflexões aparecem como bâsicas para a apresentação de elementos que dinamizem um debate, reforcem a procura de novos caminhos para o repensar da profissão, o que só serâ frutificado mediante um esforço coletivo. Esses novos rumos, acreditamos, têm que partir da consideração do passado vivido pela profissão, o qual, submetido a uma crítica à base do conhecimento científico, resgate seus elementos substanciais. Esta é uma condição indispensâvel à formulação de novas estratégias para a ação dos agentes profissionais que se 
propõem a atuar a serviço dos interesses dos trabalhadores. Estratêgias que deverão apoiar-se na anâlise rigorosa da rea lidade, superando o mero voluntarismo dos agentes individuais. Nesse sentido, o indagar-se sobre a legitimidade social da de manda do Assistente Social traz à superfície um elemento essencial para a superação de um tipo de prätica profissional controladora dos setores populares; procura ultrapassar a mera revisão de formas de atuar numa linha de modernização do aparato teôrico-prâtico da instituição Serviço Social, para situâ-1a a partir das relações de força entre as classes fundamentais da sociedade.

Importa ressaltar, ainda, algumas condições que cercaram a elaboração deste trabalho. Como todo texto, expressa a trajetória de quem o elaborou. Assim, manifesta a busca de cobrir deficiências de formação teórica, inerentes ao ensino universitärio e particularmente, à graduação em Ser viço Social. Implicou, portanto, em um esforço sistemático de superar lacunas da formação profissional de origem e incorporar estudos efetuados a nível do curso de pôs-graduação, alia dos a uma reflexão crítica sobre a prätica vivenciada.

0 fato de ser um campo praticamente novo de pesquisa e elaboração analítica trouxe dificuldades complemen tares ao trabalho, à medida que se defrontou com a quase inexistência de estudos sociológicos sobre o tema, especialmente na perspectiva analitica aqui assumida.

A parcimoniosa referência à literatura especia lizada de Serviço Social deve-se aos motivos anteriormente re feridos e ao fato de que tornava-se difícil e delicado selecionar a bibliografia incorporada nesses anos de profissão. Acresce-se, tambëm, que as fontes documentais utilizadas na pesquisa sobre a história do Serviço Social no Brasil, que subsidiou este ensaio, não comportavam citação dado o carâter predominantemente teórico desta dissertação. 
O segundo capítulo -- Uma Concepção Teôrica da Reprodução das Relações Sociais -- expressa os fundamentos ana líticos, segundo a concepção marxista, para a compreensão da reprodução das relações sociais, como premissa fundamental pa ra situar o Serviço Social nesse processo. Procura-se apreen der a vida em sociedade em uma perspectiva de totalidade, como produção e reprodução de relações sociais historicamente determinadas e das contradições que as permeiam, evitando-se a reificação de categorias econômicas. Ressaltam-se as expres sões simultaneamente econômico-políticas e ideológicas dos fenômenos sociais. No desenvolvimento do texto existe uma $1 \underline{i}$ nha metodolögica bâsica que permeia toda a exposição: desven dar por que, na sociedade do capital, relações sociais entre pessoas, enquanto personificam interesses de classe, aparecem como relações entre coisas, em que os sujeitos desse processo submergem, para transparecer, na superfície da sociedade, as coisas, isto $\vec{e}$, as mercadorias que possuem, e mediadas pelas quais entram em relação. Trata-se, portanto, de elucidar e ar ticular as relações sociais e as formas sociais por intermé dio das quais necessariamente se expressam, ao mesmo tempo em que encobrem seu caráter mais substancial. O desencadeamen to dessa linha de raciocínio parte da mercadoria simples e de seu fetiche, como forma social bâsica e pressuposto da sociedade capitalista. Acentua-se, a seguir, o processo de trans formação da mercadoria em capital, ressaltando as novas deter minações do processo de trabalho enquanto processo de valorização do capital, de produção de mais-valia. Face à reprodu ção ampliada do capital, são expressas as mistificações que permeiam o ciclo do capital, as relações entre capital e trabalho.

o terceiro capítulo está voltado para um apro fundamento sobre a divisão do trabalho na sociedade e no inte rior da produção, dentro de uma linha que procura apreender a historicidade dessa noção, isto é, compreender as formas es 
pecíficas que assume nos vârios estägios de desenvolvimento do capitalismo. Parte-se da divisão do trabalho na produção mercantil simples, especificando suas peculiaridades na produ ção manufatureira e na grande indüstria capitalista. Destacase ainda, os fundamentos da divisão do trabalho na sociedade, a partir do momento em que a mercadoria torna-se o elemento mediador das relações sociais. Este texto tem em vista subsidiar algumas indicações, feitas nos capitulos subsequentes, so bre a inserção da profissão na divisão capitalista do traba 1ho.

O capítulo quarto -- O Serviço Social no Processo de Reprodução das Relações Sociais -- orienta-se no sen tido de situar a profissão na reprodução das classes sociais fundamentais, recuperando a orientação teórica supramenciona da para apreender essa expressão particular do trabalho coletivo. Representa um intento de compreender o significado social dessa profissão. O texto tem por objetivo bäsico a construção de hipóteses diretrizes de trabalho.

A prâtica institucional do Serviço Social, de mandada pela classe capitalista e por seus representantes no Estado para intervir junto aos trabalhadores, $\vec{e}$ apreendida co mo uma atividade auxiliar e subsidiāria no exercício do controle social e na difusão da ideologia dominante. Atua, ainda, pela mediação dos serviços sociais, na criação de condi ções favorecedoras da reprodução da força de trabalho. Sendo - exercício profissional polarizado pela luta de classes, o Serviço Social tambëm participa do processo social, reprodu zindo as contradições próprias da sociedade capitalista, ao mesmo tempo e pelas mesmas atividades pelas quais é chamado a reforçar as condições de dominação. Se, de um 1ado, o profís sional é solicitado a responder às exigências do capital, de outro, participa, ainda que subordinadamente, de respostas às necessidades legítimas de sobrevivência da classe trabalhado ra. Procura-se, pois, apreender o movimento contraditório da 
prática profissional no jogo das forças sociais presentes na sociedade. Subsidiando o desenvolvimento analitico das hipớte ses, são ressaltadas algumas caracteristicas do agente profis sional nas relações sociais; as fontes de legitimidade de sua demanda, a condição de trabalhador assalariado e de intelec tual, o suporte simbölico que, dominantemente, sustenta a atua ção têcnica, etc. Como o Assistente Social atua na implementa ção de medidas de política social concretizadas atravês dos serviços sociais, procura-se marcar o significado desses serviços na sociedade burguesa, na ótica do capital e do traba1ho.

No ûltimo capitulo, de caráter conclusivo, ca racteriza-se o processo de legitimação e crise do Serviço So cial na sociedade brasileira nas três ủltimas dếcadas. Como o surgimento e desenvolvimento dessa instituição ê vista neste ensaio a partir do prisma da "questão social", isto é, da ex pansão do proletariado com expressão polîtica própria, colo ca-se em relevo as novas peculiaridades da "questão social" no capitalismo monopolista. Numa conjuntura histórica marcada pelo autoritarismo, e pela pauperização crescente da classe trabalhadora, o tratamento dessa questão passa a ser presidido pela articulação entre repressão e assistệncia, subordinan do-a aos preceitos da doutrina de segurança nacional e aos re quisitos da acumulação. E dentro desse panorama que são ressaltadas as respostas dadas pela categoria profissional às no vas características da demanda: a atualização da herança conservadora do Serviço Social e a busca da ruptura com a mesma. Condicionando essas respostas considera-se algumas particularidades do Assistente Social como intelectual. Caracteriza-se - pensamento e a utopia conservadoras incorporados pelo Servi ço Social desde suas origens. A atualização dessa herança se traduz numa modernização da instituição, para atender aos requisitos da acumulação capitalista e como garantia de renova ção de sua legitimidade junto as instâncias mandatárias. Es- 
sas mudanças são vivenciadas por uma expressiva parcela do meio profissional como "crise" profissional, que se resolve no mero aprimoramento técnico-operativo da prâtica de Serviço Social. Por outro lado, segmentos minoritärios de Assistentes Sociais passam a questionar a própria legitimidade da demanda que lhe é apresentada, buscando reorientar sua prätica segundo os interesses sociais daqueles setores que são o alvo de sua intervenção, isto $\vec{e}$, os trabalhadores, na tentativa de ruptura teórico-prática com a herança conservadora do Serviço Social. Aí, a "crise" profissional não se resolve apenas no âmbito estrito da profissão por tratar-se de uma questão eminentemente política, cujos rumos dependem da correlação de forças entre as classes sociais na sociedade e frente às quais cabe ao profissional posicionar-se, somando-se àqueles que lutam por conquistar um novo lugar no cenärio da história. 
2. UMA CONCEPÇAO TEORICA DA RËPRODUÇAO DAS RELAÇסES SOCIAIS

Para situar o significado da profissão de Ser viço Social no processo de reprodução das relações sociais, faz-se necessărio, inicialmente, procurar apreender o movimen to no qual o atravês do qual se engendram e se renovam as relações que peculiarizam a formação social capitalista. Buscar detectar no processo da vida social sua realidade substancial e as formas que reveste é uma tarefa preliminar.

E este referencial teórico que fornecerá os subsídios para análise do objeto de estudo. Trata-se, portanto, de um primeiro nível de reflexão mais geral e de maior ní vel de abstração, para, em seguida, voltar à profissão, captando-a na sua significação histôrica. 
2.1. A Produção Capitalista é Produção e Reprodução das $R$ e lações Sociais de Produção

E na vida em sociedade que ocorre a produção. A produção é uma atividade social. Para produzir e reproduzir os meios de vida e de produção, os homens estabelecem determi nados vínculos e relações mútuas, dentro e por intermédio dos quais exercem uma ação transformadora da natureza, ou seja, realizam a produção. A produção do indivíduo isolado é uma abstração. A relação entre os homens na produção e na troca de suas atividades varia de acordo com o nivel de desenvolvimento dos meios de produção. Tais relações se estabelecem. portanto, em condições históricas determinadas, nas quais os elementos da produção articulam-se de forma especifica. Assim sendo, a produção social é essencialmente histōrica. Aqui, trata-se de uma produção social na sua especificidade: a produção capitalista.

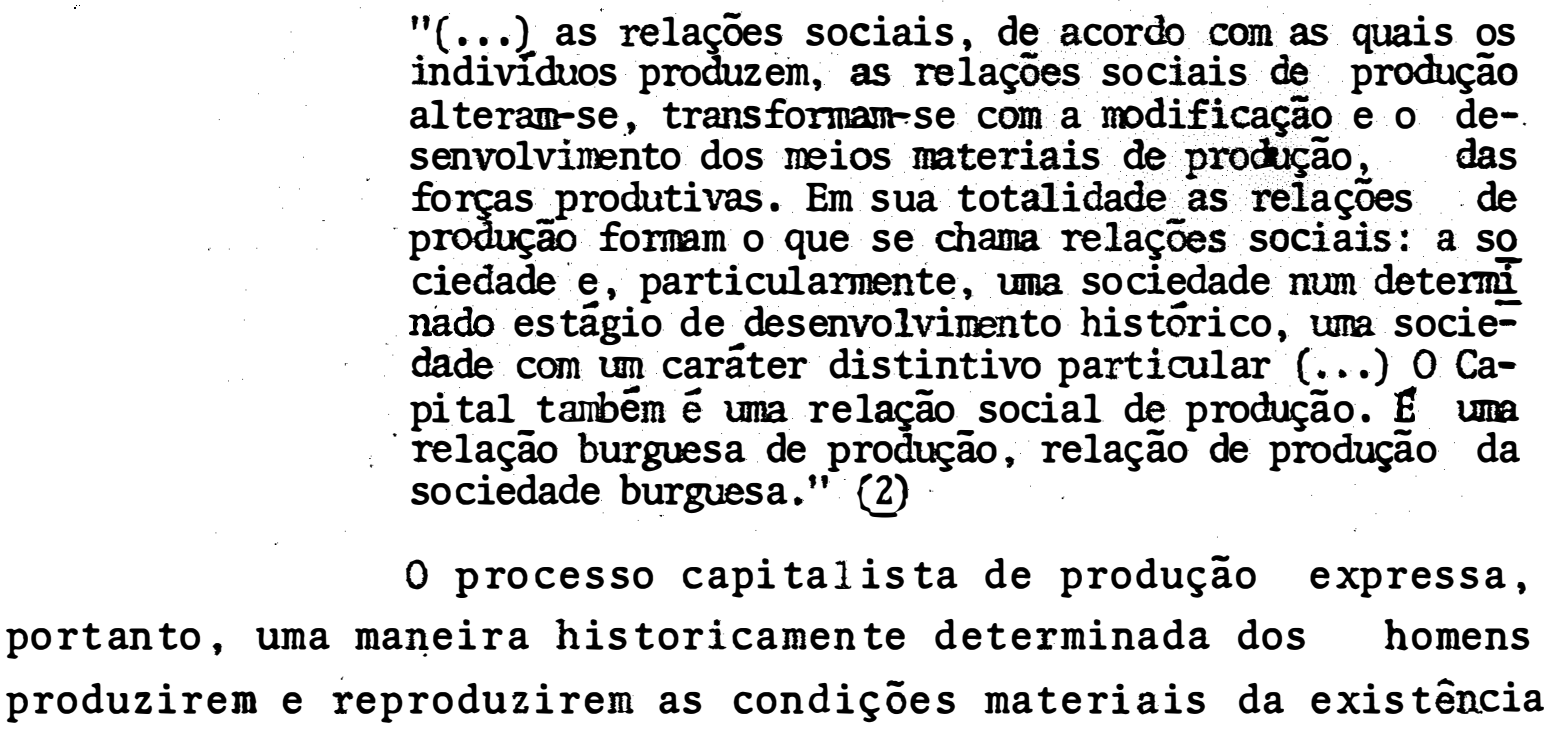

(1) Esta concepção es tá presente no conjunto das obras de Karl Marx. Ver especialmente: K. Marx. El Capital. Crítica de la Economía Política. Mexico, Fondo de Cultura Económica, 2a. ed., 5a. reímpressao. 3 tomos . 1975; El Capital, libro I, Capítulo VI (Inédito). Buenos Aires, Siglo XXI. 3a. ed., 1973; Trabalho assalariado e capital." In: K. Marx e F. Engels. Textos 3. São Paulo, Ed. Sociais, 1977. p. 60-93.

(2) K. Marx. "Trabalho...", op. cit. p. 69. 
humana e as relações sociais atravês das quais levam a efeito a produção. Neste processo se reproduzem, concomitantemente, as idéias e representações que expressam estas relações e as condições materiais em que se produzem, encobrindo 0 antagonismo que as permeia.

Assim, a produção social não trata de produção de objetos materiais, mas de relação social entre pessoas, entre classes sociais que personificam determinadas categorias econômicas. (프)

$\mathrm{Na}$ sociedade de que se trata, o capital é a re lação social determinante que dã a dinâmica e a inteligibilida de de todo o processo da vida social.

Sendo o capital uma relação social, supõe o ou tro termo da relação: o trabalho assalariado, do mesmo modo que este supõe o capital. Capital e trabalho assalariado são uma unidade de diversos; um se expressa no outro, um recria o outro, um nega o outro. 0 capital pressupõe como parte de si mesmo o trabalho assalariado.

"Capital não ê uma coisa material, mas uma determinada relação social de produção, correspondente a uma determinada fómação histórica da sociedade, que toma corpo em una coisa material e the infunde un caräter social específico. O capital é a soma dos meios materiais de produção produzidos. E o conjunto dos meios de produção convertidos em capital, que em si, tem tão pouco de capital como o ouro e a prata, como tais, de dinheiro. E - conjunto dos meios de produção monopolizados por uma determinada parte c'a sociedade, os produtos e as condiçöes de evercício da força de trabalho substantivadas frente $\bar{i}$ foinca de trabalho viva e a que este antagonismo personifica como capital." (4)

(3) "A economia não trata de coisas, mas de relações entre pessoas, e em ultima instância entre classes sociais; embora estas relações estejam sempre ligadas a coisas e apareçam como coisas." F. Engels. "Contribuição à Crítica da Economia Política" de Karl Marx. In: K. Marx e F. Engels. Textos 3. São Paulo, Ed. Sociais. p. 311, 1977.

(4) K. Marx. El Capital. Crítica de la Economia Política, op. cit., t. III, p. 754 . 
A reificação do capital, isto ê, sua identificação com coisas materiais (os meios de produção) é típica daqueles que não conseguem distinguir as formas em que as relações se expressam destas mesmas relações. O capital se expressa através de mercadorias (meios de produção e de vida) e do dinheiro. Estas formas que o representam são necessärias porque criadas e recriadas no movimento mesmo da produção. Tais formas exteriores são aparências necessärias que fazem parte dos pröprios fenômenos, atravês das quais se manifesta a substância real dos mesmos. Ao mesmo tempo que as expressam, as encobrem, pois as relações aparecem invertidas naquilo que realmente são: aparecem como relações entre mercadorias, embora não sejam mais que expressões de relação entre classes so ciais antagônicas.

As relações sociais aparecem, pois, mistificadamente, como relações entre coisas, esvaziadas de sua histori cidade. A reificação do capital è, pois, a forma mistificada em que a relação social do capital aparece na superfície da socie dade. ( $(5)$

Cabe, porëm, a indagação: Por que a produção e reprodução do capital $\bar{e}$ uma relação social historicamente dada que aparece como produçäo e reprodução de coisas?

Para responder a esta questão, vamos partir do capital como mercadoria, tentando desvendar o mistério que acon panha esta forma social tïpica da sociedade burguesa. Em segui da, procuraremos detectar em que condições as mercadorias se

(5) "Os economistas, prisioneiros das representações nas quais se movem os agentes capitalistas de produção, incorrem em um "quid pro quo" dup1o, porem reciprocamente condicionado. Por una parte, transformam o capital, de relação em uma coisa, em um conjunto de mercadorias, as quais, na medida em que servem como condições de novo trabalho, se denominam capital (...) Por outra parte, transformam as coisas em capital, isto $\vec{e}$, consideram a relação social que se representa nelas e através delas como una propriedade que corresponde à coisa enquanto tal, tão logo a mesma ingressa como elemento no processo de trabalho ou no processo tecnológico." K. Marx. El Capital, libro I, cap. VI, op. cit., p. 3, nota 3. 
transformam em capital, desvendando o que ocorre no mercado e no processo de trabalho caracteristicos da sociedade capitalis ta. Finalmente, nos deteremos na reprodução do capital como re produção ampliada das relações de dominação e as mistificações que a acompanham.

A partir deste quadro analítico poderemos levantar algumas hipóteses sobre o Serviço Social e a Reprodução das Relações Sociais.

\subsection{O Capital como Relação Social.}

2.2.1. O Capital e a Forma Mercadoria ( $\underline{6})$

- Capital se expressa sob a forma de mercadorias: meios de produçäo (matérias-primas e auxiliares e instru mentos de trabalho) e meios de vida necessärios à reprodução da Força de Trabalho.

As mercadorias são objetos üteis, produtos de um trabalho de qualidade específica (trabalho ütil concreto), que atendem a necessidades sociais; como objetos úteis, de qua lidades materiais diferenciadas, são valores de uso. 0 valor de uso ê a própria materialidade da mercadoria e se realiza no consumo dos objetos üteis.

(6) "A riqueza das sociedades onde impera o regime capitalista de produção se nos parece como 'un imenso arsenal de mercadorias e a mercadoria cơno sua forma elementar'. Por isso nossa investigação parte da mercadoria." K. Marx. El Capital. Crítica de 1a Economia Política, op. cit., t.I, cap. I, p. 4. Porem e sob a hegemonia do capital industrial que a mercadoria se transforma em forma geral e necessária, não só dos produtos do trabalho, mas também das condições de produção (meios de produção, Força de Trabalho); o mundo da mercadoria atinge a propria Força de Trabalho, que passa a encontrar-se no mercado para ser comprada e vendida, dotada de sua qualidade específica de ser uma mercadoria cujo valor de uso possui a virtude particular de ser fonte de valor, de modo que consumi-la significa realizar trabalho e, portanto, criar valor.

Esta parte do texto está fundamentalmente baseada na obra supra referi da, t. I, cap. I, p. 3-55: partimos da mercadoria simples, porque esta é a premissa básica para que os produtos ingressem no ciclo do capital. 
"Os valores de uso forman o conteñdo material da rique$z a$, qualquer que seja a forma social desta. No tipo de sociedade a que nos propomos a estudar, os valores de uso, são, ademais, o suporte material dos valores de troca." (7)

Mas as mercadorias não são apenas valores de uso; são grandezas ou magnitudes sociais que têm em comum o fa to de serem produto do trabalho humano geral e indiferenciado (trabalho abstrato); são valores enquanto materialização de força humana de trabalho. Enquanto grandezas sociais não se distinguem por sua qualidade, mas pela quantidade de trabalho que têm incorporado. São valores que se medem pelo tempo de trabalho socialmente necessārio, ( $(\underline{8})$ incorporado na sua produção. E esta "substância comum" que viabiliza que objetos üteis de qualidades diversas sejam trocados numa relação equivalente. o valor das mercadorias só se expressa na relação de troca. Na expressão dos valores se distinguem dois pölos: a mercadoria, cujo valor se expressa (forma relativa), e aquela em que se ex pressa este valor (forma equilavente). Assim é que a proporção em que as mercadorias são trocadas se expressa numa relação quantitativa de mercadorias, em que uma classe destas assume a função de equivalente; isto é, representante do valor das demais mercadorias que entram na relação de troca. Historicamente, es te papel de equivalente geral, de forma de expressão do valor das mercadorias, aderiu-se ao ouro que se converteu em mercado ria dinheiro.

(7) K. Marx. El Capital. Crítica de 1a Economia Política, op. cit., t. I, cap. I, p. 4 .

(8) 'Tempo de trabalho socialmente necessärio é aquele que se requer para produzir un valor qualquer, nas condições normais da produção e com o grau médio de destreza e intensidade de trabalho imperantes na sociedade." K. Marx. El Capital. Crítica de la Economi a Política, op. cit., t. I, cap. I, p. $6 \mathrm{e}^{7}$. 
Os produtos assumem, historicamente, a forma de mercadoria porque são produtos de trabalhos privados que ne cessitam ser trocados. (9) São valores de uso para outros, enquanto, para seu possuidor, não têm outra utilidade que a de ser valor de troca e, portanto, meio de troca. Porém, sendo as mercadorias produto de trabalhos privados, têm um carăter social que decorre do fato de que:

a) por um 1ado, sendo produtos de um trabalho ütil, têm que satisfazer uma determinada necessidade social e, portanto, integrar-se no trabalho coletivo da sociedade, dentro da divisão social do trabalho;

b) por outro lado, este trabalho só pode satis fazer uma necessidade de seu produtor à medida que possa ser trocado por outro trabalho ütil, que lhe seja equivalente (já que são não-valores de uso para quem os produz e, sim, para outros). Para que seja possível a troca de produtos de qualida des diferenciadas, fruto de trabalhos de qualidades determinadas, tem-se que abstrair da desigualdade real destes trabalhos materializados nos objetos para que apareça, subjacente aeles, sua igualdade a todos os outros tipos de trabalho, enquanto des gaste de força humana de trabalho -- trabalho humano geral.

(9) "Para que estas coisas se relacionem umas com as outras, $\vec{e}$ necessärio que seus guardiães se relacionem entre si como 'personas' cujas vontades moram naqueles objetos, de tal modo que cada possuidor de uma mercađoría só possa apoderar-se da de outro por vontade deste e desprendendo-se da sua própria; isto é, por meio de um ato de vontade comum a ambos. E necessärio, por conseguinte, que ambas as pessoas se reconheçam como proprie tários privados.

Esta relação jurídica que tem por forma de expressão o contrato, e ache-se ou não legalmente regul arentada, ê uma relação de vontade em que se reflete a relação econômica. O conteủdo desta relação juridica ou de vontade é o da relação econômica mesma. Aqui, as pessoas so exístem umas $\overline{\text { para as }}$ outras como representantes de suas mercadorias, isto $\overline{\mathrm{e}}$, como possuidores de mercadorias." K. Marx. El Capital. Crítica de la Economia Politica, op. cit., t. I, cap. II, p. 48. Grifos do autor 
Este duplo carāter social do trabalho é o que permite aos diversos produtores equipararem seus produtos no ato da troca como valores. O que fazem, ao trocar suas mercado rias, é equiparar seus diversos produtos como modalidades do mesmo trabalho, embora não o saibam. (10).

Nas relações que os homens estabelecem atravês da troca de seus trabalhos equivalentes, materializados em objetos, o caráter social de seus trabalhos aparece como sendo relação entre os produtos de seus trabalhos, entre coisas, independentes de seus produtores. (11)

0 que aparece como relação entre objetos materiais ê uma relação social concreta entre homens oculta por trās das coisas.

Constata-se, pois, um caräter misterioso das mercadorias, mistério esse que faz com que as relações sociais entre pessoas, expressas através de relações materiais entre coisas, apareçam invertidas. Isto ê, apareçam como relações ma teriais entre pessoas e relações sociais entre coisas, alheias de seus produtores. De onde decorre esse carăter misterioso das mercadorias?

(10) K. Marx, El Capital. Crítica de la Economía Política, op. cit., t. I, cap. I, p. 39 .

(11) "A forma mercadoria e a relação de valor dos produtos do trabalho em que esta forma se corporifica, não tem nada a ver com seu carăter físico nem com as relações materiais que deste carāter se derivam. 0 que aqui reveste, aos olhos dos homens, a forma fantasmagórica de uma relação entre objetos materiais não é mais que uma relação social concreta estabelecida entre os mesmos homens. Por isso, se quisermos encontrar uma analogia a es tes fenônenos teremos que remontar às regiões nebulosas do mundo da reli= gião, onde os produtos da mente humana assemelham-se a seres dotados de vi da própria, de existência independente e relacionados entre si e com os hô mens. Assim acontece no mundo das mercadorias com os produtos da mão do ho mem. A isto eu chamo fetichismo, sob o qual se apresentam os produtos do trabalho. Tão logo se criam na forma de mercadorias, e que é inseparävel, consequentemente, deste modo de produção. K. Marx. El Capital. Crítica de la Economía Política, op. cit., t. I, cap. I, p. 38 . 
Ao responder a esta questão, o autor afirma não decorrer nem do valor de uso, nem das determinações de seu valor, mas sim da própria forma mercadoria. Isto porque, na mercadoria,

"a igualdade dos trabalhos humanos fica disfarçada sob a forma de igualdade dos produtos do trabalho como valo res; a medida por meio da duração, de dispêndio da força humana de trabalho, toma a forma de quantidade de valor dos produtos do trabalho; finalmente, as relações entre os produtores, nas quais se afirma o caréter so cial de seus trabalhos, assumem a forma de relação so= cial entre os produtos do trabalho." (12)

Este fetiche da mercadoria simples reaparece sob novas formas e novas determinações na mercadoria produto do capital, dando origem ao que o autor denomina "mistificação do capital".

\subsubsection{A Transformação da Mercadoria em Capital}

O valor capital se expressa em mercadorias: meios de produção e meios de subsistência. Mas nem toda soma de mercadorias $\bar{e}$ capital. (13) 0 capital supõe o monopólio dos meios de produção e de subsistência por uma parte da sociedade -- a classe capitalista -- em confronto com os trabalhadores desprovidos das condições materiais necessárias à materialização de seu trabalho. Supõe, o trabalhador, que, para sobre

(12) Adotou-se aqui a tradução brasileira: O Capital -- Crítica da Econonia Política. Livro I, v. I, 3a. ed. Trad. de Reginaldo Sant'Anna. Río de Janeiro, Civilização Brasileira, 1975. p. 37.

(13) "Como, então una soma de mercadorias, de valores de troca, se trans forma em capita1? Conservando-se, multiplicando-se como forca social independente, isto é, como força de una parte da sociedade, atraves da troca pela força de trabalho imediata, viva. A exístencia de uma classe que possui apenas sua força de trabalho e uma condição preliminar necessāria ao capital. E exclusivamente o dominio do trabalho acumulado, passado, materializado, sobre o trabalho imediato, vivo, que transforma o trabalho acumlado em capital". K.Marx. "Trabalho assalariado e capital", op.cit., p.70. 
viver, só tem a vender a sua força de trabalho. O capital supöe o trabalho assalariado e este, o capital. (14)

0 capital na sua forma elementar de dinheiro ou mercadoria sö ë potencialmente capital; deve se transformar em capital real e efetivo no processo de produção, mediante a in corporação da força de trabalho viva, que conserva os valores das mercadorias que ingressam no processo produtivo e cria novos valores.

Enquanto o dinheiro representa uma soma dada de valores, isto é, tem uma magnitude constante, o capital $\vec{e}$ una soma de valor que tende a crescer. $E$ empregado tendo em vista a sua conservação e o seu engrandecimento. 0 produto da produção capitalista não é apenas um valor de uso, nem um produto que tem valor de troca. "Seu produto é a mais-valia; ou seja, seu produto são mercadorias que possuem mais valor de troca, isto $\vec{e}$, representam mais trabalho que o que foi adianta do para a sua produção sob a forma de mercadoria ou de dinheiro." (15) A função específica do capital é a produção de um sobrevalor ou de um valor maior que aquele adiantado no início do ciclo produtivo. Este sobrevalor ou mais-valia é o fim e o resultado do processo capitalista de produção. Significa substancialmente materialização de tempo de trabalho excedente, trabalho não pago apropriado pela classe capitalista. (16)

(14) E nossa intenção desenvolver conceitualmente esta afirmativa inicial. O desenvolvimento do raciocínio que aqui se segue está baseado principalmente em K. Marx. E1 Capital, libro I, capítulo VI (Inédito), op.cit., p. 4-101. 33.

(15) K. Marx. E1 Capital, libro I, capítulo VI (Inédito), op. cit., p.

(16) "O ünico que distingue uns tipos econômicos de sociedade de outros $\mathrm{e}$ a forma em que este trabalho excedente é arrancado do produtor imediato -- o trabalhador (...)" K. Marx. E1 Capital. Crítica de la Economía Política, op. cit., t. I, cap. VII, p. 164 .

E ainda: "O trabalho excedente não foi inventado pelo capital. onde quer que uma parte da sociedade possua o monopölio dos meios de produção nos encontramos com o fenômeno de que o trabalhador, livre ou escravizado, tem que acrescentar ao termo de trabalho necessärio para poder viver uma 
A transformação do dinheiro em capital decompõe-se em três processos inter-relacionadọs, mas independentes, no tempo e no espaço. O primeiro: a compra e venda dos meios de produção e da força de trabalho que se desenvolve no mercado. O segundo, que se efetiva no processo de produção onde, mediante o consumo produtivo da capacidade de trabalho, os meios de produção transformam-se em produtos, os quais, além de conterem o valor do capital adiantado, contêm, ainda, a mais-valia criada. Tem-se aí a produção e reprodução de capital. E o terceiro processo, que ocorre novamente na órbita da circulação, onde se realiza o valor do capital e da mais-valia, mediante a transformação de mercadoria em dinheiro. (17)

No primeiro processo tem-se a transformação do dinheiro nas mercadorias que contituem os fatores de produção. E um ato de troca de mercadorias, premissa do processo global de produção. O valor capital ingressa no processo de produção sob a forma de mercadorias determinadas, revestindo a dupla for ma de valores de uso e de troca, nas quais intervêm determinações mais complexas que as diferem da mercadoria simples.

Enquanto as mercadorias isoladas devem ter qualquer valor de uso, de modo a atender a uma necessidade so-

quantidade de tempo suplementar, durante o qual trabalha para produzir os meios de vida destinados ao proprietärio dos meios de produção, dando no mesmo que este proprietärio seja (...) ateniense, teocrata, etrusco, o "ci vis romanus", o barão normando, o escravista norte-americano, o boiardo da Valäquia, o proprietärio de terras moderno ou o capitalista. Sem düvida, $\bar{e}$ evidente que naquelas sociedades econômicas em que não predominava o valor da troca, mas o valor do uso do produto, o trabalho excedente se achava circunscrito a un setor mais ou menos amplo de necessidades, sem que do caräter mesmo da produção brote uma fome insaciävel de trabalho exceden-. te." K. Marx. El Capital. Critica de la Economia Politica, op. cit., t. I, cap. VIII, p. 181 .

(17) "E todo es te processo, a transformação do dinheiro em capital, ope ra-se na ôrbita da circulação e não opera nela. Opera-se por meio da circulação, pois está condicionada pela compra de força de trabalho no mercado de mercadorias. Não se opera na circulaçăo, porque este processo não faz mais que iniciar o processo de valorização, cujo centro reside na órbi ta da produção." K. Marx. El Capital. Crítica de 1a Economía Política, opcit., t. I, cap. V, p. 145-6. 
cial, a forma valor de uso do capital é determinada pela natureza do processo de trabalho, devendo constituir-se dos elemen tos do mesmo: objetos e meios de trabalho. Deve constituir-se de meios de produção objetivos (instrumento de produção, matérias-primas e auxiliares) e força de trabalho com uma especialidade determinada. correspondente ao particular valor de uso dos meios de produção, capaz de transformá-los em produtos. Es ta força de trabalho é a condição subjetiva da produção. (18)

A transformação do dinheiro em capital exige, portanto, que os possuidores de dinheiro encontrem no mercado não sô os meios objetivos de produção como mercadorias, mas também uma mercadoria especia1; a força de trabalho, cujo valor de uso tem a qualidade de ser fonte de valor, isto é, cujo consumo é ao mesmo tempo materialização de trabalho e, portanto, criação de valor.

Tal fato supõe que o capitalista encontre no mercado o trabalhador livre, (19) is to é, livre de outros vínculos de dominação extra-econômicos, proprietārio de sua pessoa, a fim de que possa enfrentar-se no mercado com os possuidores do dinheiro, em uma relação entre possuidores juridica mente iguais de mercadorias, através das quais entram em relação (o dinheiro, expressão dos meios de subsistência, e a força de trabalho): o proprietārio da força de trabalho a cede ao comprador para o seu uso durante certo período de tempo. Esta

(18) 'Entendemos por capacidade ou força de trabalho o conjunto de con dições físicas e espirituais que se dão na corporeidade, na personalidade viva de um homem e que este põe em ação ao produzir valores de uso de qual quer classe." K. Marx. El Capital. Crítica de la Economía Política, op-. cit., t. I, cap. IV, p. 121 .

(19) "Para converter o dinheiro em capital, o possuidor do dinheiro tem, pois, que encontrar-se no mercado, entre as mercadorias, com o trabalhador livre; livre em um duplo sentido, pois de um lado teră que poder dispor livremente de sua força de trabaiho como sua própria mercadoria; e de outro lado não deve ter outra mercadori a para vender; deverá encontrarse, portanto, livre de todos os objetos para realizar por conta própria sua força de trabalho." K. Marx. El Capital. Crítica de la Economía Politica, op. cit., t. I, cap. IV, p. 122 . 
è a condição para que se mantenha como proprietário de sua mer cadoria, podendo tornar a vendê-la. A esta condição se alia ou tra, qual seja, o trabalhador (classe trabalhadora) se vê obri gado a vender, para sobreviver, a única mercadoria que possui: sua força de trabalho. Ou seja, vende parte de si mesmo, já que de outro lado se lhe enfrentam como propriedade alheia todos os meios de produção e condições de trabalho necessários à materialização de seu trabalho, assim como os meios necessärios à sua subsistência.

Para sobreviver, o homem precisa produzir os seus meios de subsistência e, para isso, tem que dispor dos meios necessáxios à sua produção. Quando o trabalhador está desprovido dos meios de produção, estâ, tambẻm, desprovido dos meios de subsistência. A medida que estes se contrapõem ao tra balhador, como propriedade alheia monopolizados por uma parte da sociedade - a classe capitalista - não lhe resta outra a 1 ternativa senão vender parte de si mesmo em troca do valor equi valente aos meios necessários para sua subsistência e de sua família, (20) expressos através da forma do salário. A condição histórica para o surgimento do capital e o pressuposto essencial para a transformação do dinheiro em capital é a existência no mercado da força de trabalho como mercadoria.

(20) Segundo Marx, o valor da força de trabalho é determinado como o de qualquer outra mercadoria, isto $\vec{e}$, pelo tempo de trabalho socialmente necessário para sua produção, incluindo a sua reprodução. Como a força de trabalho não existe separada do indivíduo, sua produção corresponde a produção e à. reprodução do trabalhador. Neste sentido, o valor da força de trabalho equivale ao tempo de trabalho necessário para a produção dos meios de subsistência indispensâveis para a satisfação de necessidades básicas do trabalhador e de sua família (alimentação, educação, habitação, etc.). Inclui a reprodução da prole do trabalhador, pois, para que a força de tra balho se renove continuamente no mercado como mercadoria, é necessārio que seu vendedor se perpetue através da procriação. O mínimo vital para atender as necessidades bäsicas e o modo de safístazê-las varia de acordo com o nível de cultura de um país e com os hâbitos, condições e exigências da classe trabalhadora. 0 valor da força de trabalho contém um dado histórico-moral, sendo um fator fixo nuna epoca e país determinados. K. Marx. E1 Capital. Crítica de la Economía Política, op. cit., t. I, cap. IV, p. 1245 (Restono invre). 
$\mathrm{Na}$ esfera da circulação de mercadorias se esta belece uma relação contratual -- de compra e venda -- entre pos suidores juridicamente iguais de mercadorias equivalentes: a força de trabalho e os meios de subsistência sob a forma de di nheiro. Mas o que ocorre na esfera de produção?

0 processo de produção do capital considerado como um processo que, por meio do trabalho útil, cria novos va lores de uso, é um Processo de Trabalho. (21) Mas é um processo de consumo da força de trabalho pelo capitalista. Assim sen do, é um processo de trabalho com características específicas, historicamente diferenciadas, jâ que:

a) As mercadorias compradas pelo capitalista para serem consumidas no processo de produção são sua propriedade; é o seu dinheiro transformado em mercadorias. E um modo de existência de seu capital sob a forma em que realmente pode funcionar como capital. Isto se aplicaria também ao trabalho? A força de trabalho em ação -- isto ê, o trabalho -- è uma fun ção pessoal do trabalhador, enquanto gasto de sua força vital, realização de suas capacidades produtivas. Porém, enquanto cria dor de valores, pertence ao capitalista que comprou a força de trabalho para empregá-1a, produtivamente, durante um certo perỉodo de tempo. A força de trabalho é uma potência que sō se exterioriza em contato com os meios de produção; só sendo consumida, ela cria valor. o consumo da força de trabalho pertence ao capitalista, do mesmo modo que lhe pertencem os meios de produção.

(21) " (...) No processo de trabalho a atividade do homem consegue, va lendo-se do instrumento correspondente, transformar o objeto sobre o quaI versa o trabalho, de acordo con o fim perseguido. Este processo desenboca num produto. Seu produto ê um valor de uso, uma matéria oferecida pela natureza e adaptada às necessidades kumanas mediante uma mudança de forma. 0 trabalho se compenetra e confunde com obje tos. Materializa-se no objeto, ã medida que este $\overline{\mathrm{e}}$ elaborado. E o que no trabalhador era dinamismo $\bar{e}$, agora, plasmado no produto, quietude. O trabalhador $\bar{e}$ o tecedor e o produto, 0 te cido." K. Marx. El Capital. Crítica de la Economía Política, op. cit., t. I, cap. V, p. 133 .

Esta e a característica de qualquer processo de trabalho considerado nos seus elementos gerais. 
Assim é que o trabalhador trabalha sob o controle do capitalista a quem pertence o seu trabalho. A produção capitalista supõe a cooperação em larga escala e a concentração e centralização dos meios de produção com que se defron ta o trabalhador como uma propriedade alheia. Ao capitalista e/ou a seus prepostos cabe, portanto, a função de direção e vi gilância do trabalhador coletivo, seja garantindo o emprego ra cional dos meios de produção para evitar desperdícios, seja ga rantindo a maior intensidade possível de exploração da força de trabalho.

Como as condições de trabalho e o próprio trabalho pertencem ao capitalista, este recebe tambëm, gratuitamente, a força produtiva do trabalho social derivada da cooperação, que se apresenta como força produtiva do capital. (22)

Assim como o trabalho é propriedade do capitalista o é, também, o produto do trabalho.

(22) "Como pessoas independentes, os trabalhadores são indivíduos. que entram na relação com o mesino capital, mas não entre si. Sua cooperação começa no processo de trabalho, isto è, quando jàa deixaram de pertencer a si mesmos. Ao entrar no processo de trabalho são absorvidos pelo capital. Como trabalhadores que cooperam para un resultado, como membros do organis mo trabalhador, não são mais que uma modalidade de existência de capital para o qual trabalham. Por conseguinte, a força produtiva desenvolvida pe lo trabalhador como un trabalhador social (coletivo) é a força produtiva do capital. Esta força produtiva social do trabalho se desenvolve, gratui tamente, tăo logo os trabalhadores se veem sujeitos a determinadas condi ções, a que o capital os submete. E como a força produtiva social do trabalho não custa nada ao capitalista, jā que, ademais, o trabalhador não a desenvolve antes que o seu trabalho pertença ao capitalista, parece, à pri meira vista, como se esta força fosse força produtiva inerente por natureza ao capital, a força produtiva inata a este." K. Marx. El Capita1. Critíca a la Economía Política, op. cit., t. I, cap. XI, p. 268-9 (Grífos do autor).

(23) "(...) 0 processo de trabalho è um processo entre objetos comprados pelo capitalista, entre objetos pertencentes a ele. E o produto deste processo pertence ao capitalista, da mesma forma que the pertence o produto da fermentação do vinho de sua adega." K. Marx. E1 Capita1. Crítica de la Economía Política, op. cit., t. I, cap. V, p. $13 \overline{7}$. 
b) Enquanto os meios de produção entram no processo de produção da mesma forma ütil que revestiam na circula ção, o mesmo não ocorre com a parte variāvel do capital que é trocada pela força de trabalho. O dinheiro, aqui, é uma forma modificada dos meios de subsistência do trabalhador, existente no mercado; esta parte do capital só se transforma em capital variável quando é trocada pelo trabalho, que é a substância criadora de valor. Assim, a forma de valor de uso desta parte do capital na circulação (meios de subsistência) é completamen te diferente da forma de valor de uso com que ingressa na pro dução propriamente dita (como trabalho vivo em ação).

A anālise do processo de produção capitalista como processo de trabalho esclarece o fundamento da mistificação que considera o capital como coisa. Ela decorre da forma útil, de meios de produção, que o valor capital tem, necessariamente, que assumir no processo de trabalho. Considerando-se, simplesmente, o substrato material do valor do capital, subs trato este determinado pela natureza do processo de trabalho, considerando-o, entretanto, isolado das relações sociais e das relações de propriedade que se estabelecem entre a classe capi talista e a classe trabalhadora na produção, considerar o capi tal como coisa é abstrair de sua historicidade.

0 processo de produção capitalista não é apenas um processo de trabalho, de produção de valores de uso mediante o consumo de um trabalho de qualidade especifica (traba lho concreto). E, ao mesmo tempo, um processo de valorização: de criação e conservação de valor. Nesta ótica de anālise, o que interessa è o valor da troca do capital, que se diferencia do valor de troca das mercadorias, que ingressam, como tais, no processo de produção. O importante, para perceber essa dife rença, ê verificar o que ocorre com a parte variảvel do capí tal, ou seja, aquela que é trocada pela força de trabalho. 0 valor de troca da mercadoria força de trabalho, seu custo diārio de conservação, é definido antes mesmo que esta mercadoria in 
gresse na circulação. Ele se expressa no seu preço, ou seja, no salário. Jä o seu valor de uso -- que é o próprio trabalho - só se expressa no seu consumo. A realização deste consumo supõe a existência dos meios de produção, nos quais a capacida de de trabalho se materializa. Porém, ao ser consumida, a força de trabalho jả não pertence mais ao trabalhador e sim ao ca pitalista que a comprou, temporariamente, sendo uma forma de existência de seu capital. O que busca o capitalista é, pois,o valor de uso especifico desta mercadoria que lhe permite ser fonte de valor e, portanto, criar um valor superior ao seu pre ço; mas, para que crie valor, a força de trabalho deve ter um carāter útil, enquanto apta para produzir objetos de qualidades específicas. 0 que se verifica, pois, é que o valor da força de trabalho na circulação é diferente da magnitude de valor que cria na produção. Esta parte do valor adiantado na produção, ao ser transformada em trabalho vivo em ação, adquire uma magnịtude variável; aí, tem-se não mais um valor, mas a valorização enquanto processo. 0 trabalho vivo não só conserva os valo res dos meios de produção (trabalho acumulado), mas reproduz o valor do capital variảvel e gera um incremento de valor: a mais-valia. Trata-se da força de trabalho em ação que se apresenta em processo de realização. O trabalho, como formador de valor, é aqui abstraído de seu valor de uso particular (trabatho concreto) e considerado como trabalho socialmente necessărio, indiferenciável na sua qualidade, mas diferenciável na sua quantidade; trabalho que agrega valor proporcionalmente à sua duração. Trata-se do tempo de trabalho socialmente neces sário (24) que alcança sua expressão autónoma no dinheiro, no

(24) "A fim de que o tempo de trabalho do trabalhador gere valor propor cional à sua duração, deve ser tempo de trabalho socialmente necessário. Is to é, o trabalhador deve executar, em um termo determinado, o"quantum" socialmente normal de trabalho útil, e para isto o capitalista obriga ao traba lhador que seu trabalho alcance, no mínimo, o grau medio de intensidade con̄ forme a norma social. Procurară aumentá-1o acima deste mínimo e extrair do trabalhador, emum tempo dado, o maior trabalho possível, jả que toda intensificação do trabalho superior ao grau médio the oferece mais-valia: Tra 
preço da mercadoria força de trabalho. Por isso, interessa ao capitalista aumentar a duração e intensidade do trabalho, seja prolongando a sua jornada (mais-valia absoluta), seja potenciando o trabalho acima do grau médio (mais-valia relativa),pa ra que obtenha um tempo de trabalho superior àquele necessário à reposição do salärio.

Deve-se ter claro, entretanto, que esta segmentação entre trabalho concreto e socialmente necessärio, tendo fundamento na realidade e em termos analíticos, não deve ser encarada como uma dualidade, de modo dicotômico. Trata-se de uma unidade de contrários, em que um trabalho se expressa atra vës de outro. O mesmo trabalho $\vec{e}$, ao mesmo tempo, concreto e abstrato; o tempo de trabalho socialmente necessar̂io só se expressa atravês de trabalhos üteis determinados.

0 fato de o trabalhador ser forçado a produzir um trabalho excedente determina mudanças na forma de valor de uso com que o capital se apresenta no processo produtivo. Em primeiro lugar, os meios de produção devem estar disponíveis em uma quantidade suficiente para absorver o trabalho necessário e o sobretrabalho. Em segundo lugar, a duração e a intens dade do processo de trabalho se modificam. Finalmente, as relações entre o trabalhador e os meios de produção se alteram, substancialmente. Se do ponto de vista do processo de trabalho, é o trabalhador quem emprega os meios de produção, como instru mento para a realização de seu trabalho, transformando-os em produto, no processo de valorização a relação se inverte. Aqui, o trabalho vivo é mero meio de valorização dos valores existentes expressos nos meios de produção. (25)

tará ademais, de prolongar o mais possível o processo de trabalho, mais além dos limites em que è necessário trabalhar para repor o capital variável, o salärio." K. Marx. El Capital, libro I, cap. I (Inédito), op. cit., p. 16 .

(25) "O capital não consiste em que o trabalho acumulado sirva de meio de trabalho vivo para nova produção. Consiste em que o trabalho vivo sirva de meio ao trabalho acumulado, para manter e aumentar o valor de troca des te ültimo." K. Marx. "Trabalho assalariado e capital", op. cit., p. 70. 
Estes valores sỏ se conservam e se acrescentam mediante a absorção do trabalho vivo, que se torna meio de valorização de todo o capital. Trata-se do domínio do trabalho objetivado nos meios de produção, nas coisas, sobre o trabalho vivo, ou seja, sobre o trabalhador. (26) Aí o capitalista só funciona como personificação do capital e o trabalhador como personificação do trabalho. (27)

No decorrer da presente reflexão, destacamos o processo de produção do capital como processo de trabalho e de valorização; não se trata de dois processos independentes, mas de duas dimensões do mesmo processo. Não se trabalha duas vezes para produzir um produto ütil e para criar valor e mais-va lia. O que cria o valor é o trabalho real que, tendo uma dada intensidade, materializa-se no produto em determinadas quantidades; que transforme os meios de produção em produtos de qualidades específicas. Ou seja, o processo imediato de produção é unidade do processo de trabalho e de valorização, assim como a mercadoria é unidade de valor de uso e valor de troca. Porém, na formação social capitalista, o processo de trabalho $\vec{e}$ meio do processo de valorização, jā que o objetivo primordial ' da

"A absorção pelo trabalho objetivado, passado, do trabalho vivo consti. tui o processo de autovalorização, sua transformação em capital". K. Marx.' E1 Capital, libro I, capitulo VI (Inédito), op. cit., p. 24.

(26) 'No processo de trabalho efetivo, o trabalhador consome os meios de trabalho como veículo de seu trabalho e o objeto de trabalho como matéria na qual se expressa o seu trabalho. Precisamente por isto, transforma os meios de produção na forma adequada a um fim; do produto. Do ponto de vista do processo de valorização, as coisas, porém, se apresentan diferentemente. Não é o trabalhador quem enprega os meios de produção, são os meios de produção que empregam o trabalhador (...) é o trabalho material que se conserva e se acrescenta mediante sucção de trabalho vivo, graças ao qual se converte em valor que se valoriza, em capital, e funciona como tal". K. Marx. El Capital, libro I, capítulo VI (Inédito), op. cit., p. 17.

(27) "As funçóes que exerce o capitalista näo säo outra coisa que as funçoes do capital mesmo, exercidas com consciência e vontade. 0 capitalis ta só funciona enquanto capital personificado, é o capital enquanto pessoa: do mesmo modo que o trabalhador funciona unicamente enquanto trabalho personificado, que a ele pertence enquanto suplício, porém que pertence ao capitalista como substânci a criadora e acrescentadora de riqueza". K.Marx. El Capital, libro I, capítulo VI (Inédito), op: cit., p. 19 . 
produção não é a satisfação de necessidades sociais, mas a pro dução de mais-valia, a valorização do pröprio capital.

No processo de produção do capital, os meios de produção, por meio de trabalho vivo, se transformam em produtos que são mercadorias, mas são mercadorias produto do capi tal que contêm novas determinações que as diferenciam da merca doria individual, premissa da produção capitalista, visto que:

a) Contêm trabalho pago e não pago; parte do trabalho nela objetivado equivale ao salärio, enquanto a outra $\vec{e}$ trabalho excedente, mais-valia.

b) Cada mercadoria se apresenta como parte integrante da massa total de mercadorias, como parte alíquota do produto total do capital que pode ser considerado como uma ún ca mercadoria, que contêm o valor do capital adiantado e maisvalia.

c) Para que se realize o valor do capital e da mais-valia, o volume de mercadorias vendido $\vec{e}$, aqui, essencial. (료)

A medida que o valor capital se expressa sob forma de mercadorias, tem que cumprir as funções destas: têm que ser vendidas, convertidas em dinheiro, para que o valor passe a circular, e reiniciar o ciclo produtivo, sob novas for mas. Opera-se aí uma mudança na forma do valor: este, que exis tia sob a forma de produtos, existe agora sob a forma de dinheiro, mas de capital -- dinheiro que expressa o valor dos meios de produção invertidos no produto da força de trabalho e o sobrevalor criado no processo produtivo.

(28) Sobre a mercadoria produto do capital, ver K.Marx. El Capital, 1ibro I, capítulo VI (Inédito), op: cit., cap. III. "Las Mercancias como pro duto del capita1", p. 109-37; e, tambëm E1 Capital. Crítica de la Economía Política, op. cit., t: II, seção I. "Las Metamorfosis del capital y su cic10", p. 27-135, especialmente o ciclo do capital dinheiro e do capital mercadoria. 
Esta metamorfose do valor da forma mercadoria na forma dinheiro, que ê, ao mesmo tempo, a realização do valor criado no processo produtivo, ocorre na esfera da circulação.

No "modo de produção especificamente capitalis ta", tem-se a generalização da mercadoria, que se torna a forma geral de toda a riqueza, e a alienação do produto, a forma necessāria para a sua apropriação. A própria substância da prọ dução torna-se mercadoria (e não só o excedente produzido) e as condições da produção se mercantilizam, inclusive a força de trabalho.

\subsection{Relações Sociais Mistificadas e o Ciclo do Capital}

o processo que acabamos de apresentar, de transformação do dinheiro em capital, não é algo mecânico, de simples mudanças de formas do valor capital. As metamorfoses do capital são uma condição indispensâvel para que o valor capital se movimente, se crie e se acrescente e reinicie o seu ciclo. Partimos do valor capital na sua forma dinheiro monopolizado pelo capitalista, que, no mercado e através da compra e venda das condições de produção, transforma-o em mercadorias; esta forma mercadoria do valor capital é condição indispensável para que o processo de produção se realize, jã que este é um processo de trabalho que supõe instrumentos de produção, ma tërias-primas e auxiliares e a força viva de trabalho, atravês da qual não só estes meios de produção se transformam em produ tos, mas em produtos de um valor maior que o do capital adiantado no início do processo. E no ciclo do capital produtivo que ocorre a verdadeira transformação do dinheiro em capital, isto $\hat{e}$, em valor que se valoriza, em valor que gera valor. Aí a mudança de forma é acompanhada de uma transformação real do valor. Finalmente, as mercadorias produzidas têm que se transformar novamente em dinheiro, nesta expressão substantivada do valor jâ valorizado, pois é sob esta forma que o ciclo pode se 
reiniciar. O capitalista poderä, então, transformar o valor do capital inicial e a mais-valia capitalizada em novas condições de produção, ampliando a sua escala. E nesta ültima metamorfose da mercadoria produto do capital em dinheiro (venda) que o valor do capital valorizado se realiza. (29)

0 que nos interessa aqui è destacar as relaçöes sociais atravēs das quais este processo se realiza. Para tanto, devemos considerar não o capitalista e o trabalhador in dividualmente, mas o conjunto dos capitalistas e dos trabalhadores, enquanto classes sociais que personificam categorias econömicas: o capital, o trabalho e o seu antagonismo: E, ainda, considerar o processo de produção na sua continuidade, isto $\overrightarrow{\mathrm{e}}$, na sua reprodução.

0 processo de produção, quaisquer que sejam as suas características histōricas, ê um processo que se reinicia permanentemente, jā que a sociedade não pode prescindir da pro dução e do consumo.

A reprodução é a continuidade do processo social de produção, (30) porém, uma continuidade que não se reduz à mera repetição. E uma continuidade no decorrer da qual - processo se renova, se cria e recria de modo peculiar. As condições de produção são, portanto, as da reprodução.

Aqui, trata-se de uma produção determinada his toricamente: a produção capitalista, em que o processo de trabalho é meio do processo de valorização. Desta forma a reprodu ção torna-se simplesmente um meio de reproduzir o capital, de produzir mais-valia, a qual aparece como forma de rendimento produzido pelo próprio capital e não pelo trabalho.

(29) Sobre o Ciclo do Capital, ver K. Marx. El Capital. Crítica de $1 a$ Economía Política, op. cit., t. II, seção I, p. $\overline{27-135 .}$

(30) "Portanto, todo processo social de produção considerado em seus constantes vínculos e em fluxo ininterrupto de sua renovação $\overline{\mathrm{e}}$, ao mesmo tempo, um processo de reprodução". K. Marx. El Capital. Crítica de 1a Economia Política, op. cit., t. I, p. 477-8. 
0 ponto de partida do processo capitalista de produção é a separação entre a força de trabalho e os meios de produção, que são monopolizados, privadamente, pela classe capitalista. Ao se analisar a continuidade do processo social de produção, verifica-se que o que era premissa é agora zesultado do processo. O trabalhador assalariado sai do processo de produção como ingressou, como mera força de trabalho, como fonte pessoal de riqueza que se realiza como riqueza para outros. Deixando de lado, por um momento, o desgaste de sua energia ví tal; que é consumida pelo capital no processo de trabalho, o que recebe em troca da venda da força de trabalho -- os seus meios de vida -- são consumidos na reprodução de sua vida e de sua familia. Não the resta, portanto, outra alternativa senão a de retornar ao mercado novamente, vender parte de si mesmo como condição de sua sobrevivência, jă que os seus meios de ví da estão monopolizados, tambēm, pela classe capitalista.

talista?

:Mas o que a classe trabalhadora entrega ao cap $\underline{i}$

Entrega-1he, diariamente, o valor de uso de sua força de trabalho - o trabalho de uma jornada, que não só re produz o valor de todo o capital adiantado mas cria novo valor, o que se materializa em mercadorias que são propriedade do capitalista, por ele vendidas no mercado. Mediante a sucção do trabalho, o capital não só se produz como capital, mas se reproduz: a mais-valia criada se converte em meios de consumo da classe capitalista e em capital adicional empregado em nova produção, em novo meio de exploração do trabalho assalariado.

A classe trabalhadora cria, pois, em antitese consigo mesma, os prōprios meios de sua dominação, como condi ção de sua sobrevivência. (31)

(31) "(...) 0 propprio trabalhador produz constantemente a riqueza obje tiva como capital, como uma potência estranha a ele que o explora e o domí na. E o capitalista produz, não menos constantemente, a força de trabalhōo como fonte subjetiva de riqueza, separada de seus meios de realização e ma terialização, como fonte abstrata que radica na prơpria corporeidade do trā 
Capital e trabalho assalariado se criam mutuamente no mesmo processo. A continuidade do processo de produção capitalista $\bar{e}$ um processo de produção e reprodução de clas ses sociais.

Como esse processo se engendra? Como estas relaçöes se produzem e reproduzem? quais as suas caracteristicas?

Retornemos, brevemente, ao confronto da classe capitalista e da classe trabalhadora no mercado. Aqui, o que está em jogo é compra e venda de mercadorias, supondo uma rela ção entre livres proprietārios de mercadorias equivalentes, que se diferenciam pela qualidade material de suas mercadorias: os trabalhadores, proprietários da força de trabalho, e os capita listas, dos meios de subsistência e dos meios de produção. 0 que se esconde sob esta relação de iguais?

Em troca de sua mercadoria, o trabalhador rece be a título de salärio uma parte do produto em que se traduz parcela de seu trabalho: o trabalho necessário para a sua conservação e reprodução.

o salário, embora à primeira vista apareça como o preço do trabalho, é o preço da força de trabalho. Se o trabalho fosse vendido no mercado como mercadoria, teria que existir antes de ser vendido. No entanto, se o trabalhador pu-

balhador ou, para dizê-1o brevemente, o trabalhador como trabalhador assalariado. Esta constante reprodução ou eternização do trabalhador è condi ção "sine qua non" da produção capitalista". K. Marx. E1 Capital. Crítica de la Economía Política, op. cit., t. I, cap. XXI, p. 480.

E ainda: "o trabalhador se enpobrece tanto mais quanto mais riqueza produz (...) à medida que se valoriza o mundo das coisas se desvaloriza em razão direta o mundo dos homens. O trabalho não produz só mercadorias, pro duz a si mesmo e produz o trabalhador como una mercadoria, na mesma propor ção em que produz mercadorias em geral (...) o obje to produzido pelo traba lho, seu produto, o enfrenta como algo estranho, como um poder independente de seu produtor." K. Marx. "Manus critos económico-filosoficos de 1848." In: K. Marx e F. Engels. Manuscritos econömicos varios. Barcelona, GrijalБо, 1975, p. 63 . 
desse dar uma existência independente a seu trabalho, venderia o produto do mesmo e, não, o trabalho. (프)

o salārio é o preço da força de trabalho, em que se traduz o capital variável do capitalista. (33) Mas o va lor da força de trabalho é diferente de seu rendimento; quando colocada em ação, torna-se uma magnitude variāvel; a força de trabalho em realização é um processo de valorização que não só transfere o valor dos meios de produção ao produto, mas repõe - valor do capital variável e cria novo valor. O rendimento do trabalho depende de sua duração. O capitalista compra o direito de explorar a força de trabalho durante uma jornada, na qual o trabalhador não só produz o trabalho necessário para a sua subsistência, mas um trabalho excedente ou um valor excedente. Assim, o capitalista que compra a força de trabalho a faz funcionar por mais tempo que o necessário para reproduzir o seu preço; caso contrário, só obteria o tempo de trabalho so cialmente necessărio, equivalente ao salário, não se aproprian do de qualquer trabalho excedente. Sem trabalho excedente não haveria mais-valia, e a continuidade da produção estaria comprometida, jă que esta é seu impulso e finalidade básica.

Ao aparecer como preço do trabalho, a forma sa lärio encobre toda a divisão da jornada de trabalho em trabalho necessário e excedente (pago e não pago), fazendo com que

(32) "O possuidor do dinheiro não se enfrenta no mercado de mercadorias com o trabalho, mas com o trabalhador. 0 que este vende $\bar{e}$ a sua força de trabalho. Tão logo o seu trabalho começa a colocar-se em ação, já deixou de pertencer-lhe e não pode, portanto, vender o que não lhe pertence. 0 trabalho é a substância imanente de valores, porêm, em si, carece de valor." K. Marx. El Capital. Crítica de la Economía Política. op. cit., t. I, p. 449 .

Em nota ao pé da página, o autor destaca ainda que: "o trabalho, medida exclusiva do valor (...) fonte de toda riqueza, não é una mercadoria."

(33) "O capital variável não é mais que uma forma historica concreta de manifestar o fundo de meios de vida ou o fundo do trabalho que o trabalhador necessita para o seu sustento e reprodução." K. Marx, El Capital. Crítica de la Economía Política, op. cit., t. I, p. 477-8. 
todo o trabalho entregue ao capitalista apareça (34) como tra balho pago. Esta mistificação da forma salārio não é facilmen te desvendada no cotidiano, tanto pelo capitalista, como pelo trabalhador.

"O capitalista ignora que o preço normal do trabalho envolve tambem uma determinada quantidade de trabalho não retribuído e que precisamente este trabalho não retribuído $\bar{e}$ a fonte normal de onde provêm seu lucro. Para ele, a categoria tempo de trabalho excedente não existe, pois aparece confundida na jormada normal de trabalho que crê pagar com salärio." (35)

Para melhor explicitar a "desigualdade" que se esconde sob a forma de salário, importa destacar que o tra balhador só é pago depois de ter vendido sua força de trabalho; após o seu trabalho $\vec{u} t i l$, que é ao mesmo tempo criador de va lor, ter sido colocado em funcionamento. Assim, a classe tra balhadora adianta à capitalista o seu trabalho, fornece-1he um crédito, jā que o dinheiro com que o trabalhador é pago desem penha a função de meio de pagamento: o trabalhador só recebe seu salário após sua força de trabalho ter sido consumida pro dutivamente pelo capital. Considerando o processo de produção na sua continuidade, verifica-se que a classe trabalhadora $\bar{e}$ paga com o produto de seu prōprio trabalho, do trabalho efetuado anteriormente pelo conjunto dos trabalhadores. Assim $\vec{e}$

(34) "Ademais, a forma exterior "valor ou preço do trabalho" ou "salärio", à diferença da realidade substancial que nela se exterioriza, ou seja, o valor ou o preço da força de trabalho, estā sujeita às mesmas leis de todas as formas exteriores e seu fundo oculto. As primeiras se re produzem de modo direto, e espontâneo, como formas discursivas que se de senvolvem por sua pröpria conta; o segundo é a ciência que te rá que descōo brir (...) Nesta forma exterior de manifestar-se, que oculta e faz invisí vel a realidade, invertendo-a, baseiam-se todas as idéias jurídicas! do trabalhador e do capitalista, todas as mistificações do regime capitalista de produção, todas as ilusões livre-cambistas, todas as frases apologé ticas da economia vulgar." K. Marx. El Capital. Crítica de la Economia Politica, op. cit., t. I, p. 452-454, (35) K. Marx. E1 Capital. Crítica de 1a Economia Política, op. cit., t. I, cap. XVIII, p. 46I. 
que a classe trabalhadora é quem produz o capital variảvel que posteriormente the é devolvido sob a forma de salário. (36)

Assim è que o capitalista "vende" constante mente ao trabalhador uma parte do próprio produto deste ưlti mo -- os meios necessários de sobrevivência em troca de traba 1ho - e Ihe empresta, constantemente, outra parte de seu prö prio produto -- os meios de produção -- cujo valor é, tambêm, recriado pelo trabalho. Ora, a relação entre compradores e vendedores supõe a troca de seus próprios trabalhos, o que não se verifica neste caso. Com is to se desvanece a aparência, ex pressa na circulação, de uma relação entre possuidores de me cadorias. Esta compra e venda é a forma mediadora de subjugamento do trabalhador ao capital, que se renova constantemente.

'Encobre, como mera relaçäo monetäria, a transação real e a dependência perpétua que essa intermediação de compra e venda renova incessantemente. Não só se re produzem de maneira constante as condições deste comer cio, mas o que un compra e o que o outro se về obrigado a vender é resultado do processo. A renovação cons tante desta relação de compra e venda não faz mais que mediar a continuidade da relação específica de dependencia e the confere a aparência falaciosa de uma tran sação, de um contrato entre possuidones de mercadoria, dotados de iguais direitos e que se contrapõem de maneira igualmente livre. Esta relação introdutöria agora se apresenta, inclusive, como elemento imanente des se predominio do trabalho objetivado sobre o trabalho vivo, gerado na produção capitalista. (37)

- que o capitalista devolve ao trabalhador co mo fundo de trabalho ou salário é empregado na aquisição dos meios de vida do trabalhador e de sua familia. 0 consumo indi vidual da classe trabalhadora reproduz o próprio trabalhador como trabalhador assalariado: tanto os trabalhadores atuais como os futuros, condição indispensável para a continuidade do processo de produção. Tem-se aí não só a reprodução

(36) A este respeito, ver K. Marx. El Capital. Crítica de la Economia Política, op. cit., t. I, cap. XXI. 105 (Grifos do autor). 
física da força de trabalho, mas tambêm da "tradição e acumu lação de destreza para o trabalho de geração em geração" (K. $\operatorname{Marx}$, t. I, p. 483). Embora a conservação de sua vida e proge nitura seja levada a efeito pelo proprio trabalhador, fora do processo produtivo propriamente dito, o consumo dos meios de subsistência implica a própria destruição dos mesmos, o que obriga a classe trabalhadora a comparecer novamente no mercado vendendo sua força de trabalho ao capital.

0 consumo individual do trabalhador é improdutivo para ele mesmo, pois não $f a z$ mais que reproduzir o indivíduo necessārio: số $\bar{e}$ produtivo para o capitalista $e$ para 0 Estado, visto que produz a "Gorça produtora de riqueza para outros". (38)

Assim, quando o capitalista converte parte de seu capital em força de trabalho, o que obtém é uma exploração de todo o seu capital. Obtêm vantagens não só do que extrai do trabalhador, mas do que entrega à classe trabalhadora sob a forma de salário. (39) 0 processo capitalista de produ ção reproduz o trabalhador divorciado das condições de traba lho; o reproduz como trabalhador assalariado. Esta "vassala gem econômica" se disfarça pela ocorrência da renovação perió dica da venda de força de trabalho, seja devido à troca de

t. I, p. 482 .

(38) K. Marx. El Capital. Crítica de la Economia Política, op. cit.,

(39) "Assim, dentro dos limites do absolutamente necessärio, o consumo individual da classe trabalhadora volta a converter o capital gasto em tro ca de força de trabalho em nova força de trabalho, explorâvel pelo capi= tal. E produção e reprodução do meio de produção indispensável para o capi talista, do próprio trabalhador. O consumo individual do trabalhador é, pois, um fator de produção e reprodução do capital." K. Marx. El Capital. Crítica de la Economía Política, op. cit., t. I, p. 486. 
patrões individuais, seja devido às oscilações de preço da força de trabalho no mercado. (40) Do ponto de vista social, a classe trabalhadora $\vec{e}$ um atributo do capital. Mas o pröprio processo cria as aparências mistificadoras que evitam que a revolta se expresse e garantam a continuidade do processo pro dutivo. A reprodução das relações de dominação é tambẻm repro dução das formas jurídicas igualitārias e "livres" que as mas caram.

Na esfera da circulação, na compra e venda da força de trabalho, o que distingue o trabalhador de outros vendedores de mercadorias ê o valor de uso específico da mercadoria que é fonte de riqueza: o trabalho capaz de produzir e reproduzir valor. Porëm, is to não modifica a determinação formal da transação entre compradores de mercadorias. Ou seja, não hă violação da lei de troca de mercadorias. Para demonstrar, portanto, que se trata de uma mera troca de mercadorias, basta se ater ao aspecto formal desta transação de troca de coisas, não se atendo à natureza das relações que ela encerra.

0 que imprime ao dinheiro e à mercadoria o ca răter de capital desde a circulação não é o fato de serem me cadorias e dinheiro e muito menos o valor de uso específico destas mercadorias. Mas é o fato de que as condições de produ ção e os meios de subsistência estejam alienados do trabalha dor e enfrentam-no: como coisas capazes de comprar pessoas. O trabalhador trabalha como não proprietário, e as con-

(40) "0 escravo romano se achava sujeito por cadeias à vontade do senhor; o trabalhador assalariado se acha submetido à palmatória de seu proprietärio por meio de fios invisíveis. A troca constante de patrões e a "fictio juris" do contrato de trabalho mantêm a aparência de livre persona lidade." K. Marx. E1 Capital. Crítica de la Economía Política, op. cit., t. I, p. 482 . 
dições de trabalho enfrentam-no como um poder estranho, autônomo, personificado por seus possuidores. (4l)

"As coisas que são condições objetivas de trabalho, ou seja, os meios de produrção e as coisas que são condições objetivas para a conservação do trabalhador mes mo, is to é, os meios de subsistência, số se converteñ en capital ao enfrentar o trabalho assalariado. 0 capi tal não é uma coisa, assim como o dinheiro não o é. No capital, como no dinheiro, determinadas relações so ciais aparecem como qualidates sociais que certas coi sas têm por natureza (...) Capital e trabalho assala= riado (assim denominado o trabalho do trabalhador que vende sua própria capacidade de trabalho) não expressam outra coisa que dois fatores de mesma relação. 0 dinheiro não pode transformar-se em capita1, se não se troca por capacidade de trabalho, enquanto mercadoria vendida pelo próprio trabalhador. Ademais, o trabalho só pode aparecer como trabalho assalariado quando suas pröprias condições objetivas enfrentam-no como poderes autônomos, egoístas, propriedade alheia, valor que è para si aferrado a si mesmo, em suma: como capi tal." (42)

Capital e trabalho assalariado se criam mutua mente no mesmo processo. Assim é que o processo de produção capitalista é um processo de relações sociais entre classes.

0 salärio, forma típica do mundo dos equiva lentes, encobre a desigualdade efetiva que se esconde sob a aparência de relações contratuais juridicamente iguais. 0 que ocorre no "mundo da produção" sob a aparência da igualdade expressa no "mundo da troca" de mercadorias?

(41) "Antes que o dinheiro e a mercadoria se tenham realmente transfor mado em capital (que) lhe imprime desde o início un caräter de capital, não é a sua condição de dinheiro, nem sua condição de mercadoria, nem o va lor de uso destas mercadorias que consiste em servir de meios de subsistên cia e produção, mas é o fato de que este dinheiro e esta mercadoria, estes meios de produção e de subsistência se enfrentam com a capacidade de tra-. balho -- despojada de toda riqueza objetiva -- como poderes autōnomos personificados em seus possuidores; o fato de que as condições de trabatho es tão aliemadas do trabalhador mesmo ou, mais precisamente, se apresentam có mo fetiche dotados de uma vontade e alma próprias; o fato de que mercado rias figuram como compradoras de pessoas." $K$. Marx. E1 Capital, libro I, capítulo VI (Inédito), op. cit., p. 35-7 (Grifos do autor). 38.

(42) K. Marx. EI'Capital, libro I, capítulo VI (Inédito), op. cit., p. 
Com o desenvolvimento do que Marx denomina "modo de produção especificamente capitalista", verifica-se uma revolução total no modo de produzir, ou seja, no processo de trabalho. Desenvolvem-se as forças produtivas sociais do trabalho devido à cooperação, à progressiva divisão tëcnica do trabalho, à aplicação de maquinaria, à aplicação do desen volvimento científico e tecnolögico no processo produtivo. A escala social de produção se amplia e, com isto, tambëm o vo lume mínimo de capital exigido para que os capitalistas individuais explorem produtivamente o seu capital. Tem-se a con centração e centralização do capital existente, que ampliam e aceleram as mudanças na composição tëcnica e de valor do capí tal, is to $\vec{e}$, na sua composição orgânica, (43) fazendo com que o capital aplicado nos meios de produção cresça em maior proporção que aquele aplicado na compra da força de trabalho. o trabalho $\vec{e}$, pois, potenciado, is to $\vec{e}$, verifica-se um aumen to de produtividade social de trabalho: uma quantidade menor de trabalho é capaz de criar uma maior quantidade de produtos. (44) Com isso se reduz o tempo de trabalho socialmente neces-

(43) "A composição do capital pode ser interpretada em dois sentidos. Em relação ao valor, a composição do capital depende de proporção em que se divide em capital constante ou valor dos meios de produção e capital va riável ou valor da força de trabalho, soma global dos salärios. Em relação à matëria, a seu funcionamento no proces so de produção, os capitais se dividem em meios de produção e força viva de trabalho; esta composição se de termina pela proporção existente entre massa dos meios de produção empregăa dos, de um lado, e, de outro, pela quantidade de trabalho necessário pa ra o seu emprego. Chamaremos à primeira de composição do valor e à seguñ da de composição técnica do capital. Existe entre elas uma relação de mütua interdependencia. Para expressá-1a, dou à composição de vâlor, en quanto se acha determinada pela composição técnica e reflete as mudanças operadas nesta, o nome de conposicão orgânica do capital." K. Marx. E1 Capital. Crítica de la Economia Política, op. cit., t. I, cap. XXIII, p. 5I (Grifos do autor).

(44) "O grau social de produtividade do trabalho se reflete no volume. relativo dos meios de produção que o trabalhador converte em produto, durante certo tempo e com a mesma tensão da força de trabalho (...) seja con dição ou efeito, o volume crescente dos meios de produção, comparado com $\bar{a}$ força de trabalho que absorvem, expressa sempre a produtividade crescente de trabalho." K. Marx. El Capital. Crítica de la Econouila Política. op. cit., t. I, cap. XXIII, p. 525 (Grifos do autor). 
särio para a reprodução da força de trabalho, ampliando-se o tempo de trabalho que $\vec{e}$ entregue gratuitamente ao capitalista. E o mundo da mais-valia relativa.

Como a classe trabalhadora dentro do processo produtivo não $\vec{e}$ mais que um modo de existência do capital, o desenvolvimento das forças produtivas sociais do trabalho apa rece como força produtiva do capital, como propriedades inerentes aos meios de produção enquanto valores de uso, enquan to coisas. Esta aparência se reforça à medida que, no capitalismo, observa-se um amplo desenvolvimento das forças produti vas do thabalho coletivo, que não têm comparação em ëpocas precedentes; aparecem, portanto, como algo natural à relação do capital. Por outro lado, as condições objetivas do traba tho assumem ai, devido ao trabalho combinado socialmente, uma forma modificada, como meios de produção concentrados. Po rém, este caräter social das condições de trabalho (máquinas, edifícios, etc. $\}$ aparece como algo dado, independente do tra balhador, como sendo organizado pelo capitalista e obra sua. Como o trabalho, enquanto criador de riqueza, pertence ao capital e apenas como esforço individual pertence ao trabalha dor, o desenvolvimento das forças produtivas sociais do traba tho e as condições sociais do trabalho se apresentam como se fossem fruto do capital e não do trabalho. Esta forma alienada, porêm necessária, para a subsistência do capitalismo se reflete na consciência dos homens, como se a riqueza provies se do capital e não do trabalho. O que decorre da potenciação do trabalho coletivo aparece como algo inerente às condições naturais da produção enquanto tais; o que é produto do trabalho aparece como produto do capital. Esta $\vec{e}$ a mistificaçäo do capital (45) inerente ao processo de trabalho como meio do processo de valorização. No processo social de produção, o trabalhador não sô produz mercadorias, mas capital. A força

(45) Sobre a mistificação do capital, ver K. Marx, El Capital. libro I, capitulo VI (Inédito), op. cit., p. 93-101. 
de trabalho é consumida pelo capitalista que a adquiriu como meio de valorização de valores $j \vec{a}$ existentes, e, ao mesmo tem po, o componente vivo do capital consume os meios de produção, transformando-os em produtos que têm um valor superior aquele desembolsado inicialmente. Tem-se, ai, o consumo produtivo da força de trabalho; o trabalho produtor de mais-valia. Deste processo resulta a vida da classe capitalista, isto $\bar{e}$, a maisvalia obtida é empregada tanto como fundo de consumo individual do capitalista, como para aquisição de novas corldições de produção necessárias à continuidade ampliada do processo produtivo, como capital adicional (mais-valia capitalizada). Ou seja, o trabalhador produz e reproduz o capital; produz e reproduz a classe capitalista que personifica o capital, en fim, cria e recria as condições de sua prōpria dominação. Portanto, a relação entre o trabalhador e o produto de seu trabatho ê uma relação entre o produtor e umobjeto alheio, dotado da condição de exercer poder sobre ele. A objetivação do traba1ho, desta substância criadora de riqueza, no produto, tornase para o produtor escravizạção de si mesmo aos objetos cria dos pelo seu trabalho. Mas a alienação do trabalhador não sö se expressa na sua relação com os produtos de trabalho. A alienação se manifesta no pröprio ato da produção, no traba 1ho. O trabalho aparece como algo externo ao trabalhador, co mo algo em que não se afirma, mas se nega a si mesmo; que o mortifica. Só se sente livre quando deixa de trabalhar. Seu

(46) "Consideramos o ato de alienação da atividade prätica humana, do trabaIho, em dois aspectos: 1) A relaçăo entre o trabalhador e o produto do trabalho, como objeto alheio e dotado de poder sobre ele. Esta relação $\bar{e}$ ao mesmo tempo a que o coloca ante um mundo exterior sensivel, ante os objetos da natureza como ante um mundo estranho e hostil; 2) A relação en tre o trabalho e o ato de produção, dentro do trabalho. Esta relação $\bar{e} \bar{a}$ que se estabelece entre o trabalhador e sua própria atividade, como uma atividade alheia e que não lhe pertence, a atividade como passividade, a força como impotência, a procriação como castração, a pröpria energia física e espiritual do trabalhador, sua vida pessoal, pois a vida näo $\vec{e}$ ou tra coisa que atividade -- como una atividade que se volta contra ele mes mo, independente dele, que não lhe pertence. A auto-alienação, como aci= ma, a alienação da coisa". K. Marx. "Manuscritos econômico-filosóficos de 1848, op. cit., p. 66 . 
trabalho è um trabalho forçado, que. "näo representa, portanto, a satisfação de uma necessidade, mas que $\bar{e}$ simplesmente um meio para satisfazer necessidades estranhas a ele (...) a exterioridade do trabalho para o trabalhador se revela no fato de que não ê algo próprio seu, mas de outro, de que não the pertence e de que ele mesino, no trabalho, não pertence a si mesmo, mas a outro". (47)

Contraditoriamente ao processo de alienação do trabalho, típico do processo de produção do capital, o tra balhador encontra-se numa situação mais privilegiada que a do capitalista; este encontra aí a sua satisfação absoluta--a produção de mais-valia -- enquanto o trabalhador encontra aí as condições materiais que explicam a sua rebeldia, jă que neste processo são criadas as condições materiais de uma nova forma de produção social de riqueza, de "um processo de vida social conformado de maneira nova, e com isto, de uma nova formação social". $(\underline{48)}$
"A dominação do capitalista sobre o trabalhador $\vec{e}$, con sequentemente, a da coisa sobre o homem, do trabalhō morto sobre o trabalho vivo, a do produto sobre o pro- dutor, $j a ̈$ que na realidade as mercadorias que se con- vertem em meios de dominação sobre os trabalhadores (porén, só como meios de dominação do capital mesmo) não são meros resultados do proçesso de produção, mas os produtos do mesro. Na produção material, no verda- deiro processo de vida social -- pois este é o proces- so de produção -- se dâ exatamente a mesma relação que se apresenta no terreno ideológico, na religião: conversão do sujeito em objeto e vice-versa.Considera da historicamente, esta conversão aparece como momentō de transição necessärio, para impor, pela violência e às custas da maioria, a criação de riqueza enquanto tal, is to $\vec{e}, 0$ desenvolvimento inexorave 1 das forças produtivas do trabalino social, que é o único que pode constituir a base material de una sociedade humana li- vre." (49)

(47) K. Marx. "Manuscritos económico-filosöficos de 1848", op. cit.;, p. $65-6$.

(48) K. Marx. E1 Capital, libro I, capítulo VI (Inédito), op. cit., p. $19-106$.

(49) K. Marx. E1 Capital, libro I, capítulo VI (Inédito), op. cit., p. 19. 
Esta aparente transformação de relações sociais em relações entre coisas é uma inversão inerente e prô pria ao processo de produção e reprodução do capital; não depende de um ato de vontade ou de forças externas mas da misti ficação que se ergue sobre a fonte criadora de valor que é o trabalho. Para que esta inversão se produza, a prōpria dinâmi ca de produção joga a seu favor, já que o trabalho aparece ma terializado em mercadorias, e o que predomina nesta aparência é a forma material do objeto que é propriedade privada do capitalista. Ante os olhos aparecem as coisas e desaparece a ta refa cumprida pelo esforço criador.

Vimos que as relações entre classes sociais se engendram contraditoriamente no ciclo do capital, ao mesmo tempo em que engendram as mistificações que as transfiguram em relações entre coisas, desprovidas dos antagonismos que as ca racterizam. Perguntaríamos ainda: qual a influência da acumulação ampliada do capital sobre a classe trabalhadora?

Considerando o ciclo do capital no seu conjunto, a acumulação ou reprodução ampliada do capital não é mais que um momento da continuidade da produção. Parte da mais-va lia extraída da classe trabalhadora na produção e reaıizada na circulação, através da venda das mercadorias produzidas, capitaliza-se, convertendo-se em capital adicional, reinvertido no processo produtivo. Esse aumento do volume de capital funciona como base para ampliar a escala da produção. Essa am pliação supõe a incorporação de novos meios de produção e de novos trabalhadores, ou seja, a ampliação do proletariado. $\underline{(50)}$

(50) "Assim como a reprodução simples produz constantemente o pröprio. regime do capital, de um lado capitalistas e de outro trabalhadores assa lariados, a reprodução em escala ampliada, ou seja, a acumulação reproduz o regime de capital em uma escala sumerior, cria em un pólo mais capita Iistas ou capitalistas mais poderosos e em outro mais trabalhadores assałariados (...) A acumulacão do canital simõe, portanto, um aumento do proletariado." K. Marx. El Capital. Critica de la Economia Politica, op. cit., t. I, cap. XXIII, p. 518 . 
Como o objetivo da produção è a obtenção de mais-valia, da maior lucratividade possíve1, ao capitalista só restam duas alternativas: ou aumentar a jornada de trabalho, fazendo crescer o tempo de trabalho excedente materializado (mais-valia absoluta) ou, mantendo uma dada jornada de traba1ho, aumentar a produtividade do trabalho, mediante o emprego de meios de produção mais eficazes, que permitam reduzir o tempo de trabalho socialmente necessário à produção de uma mercadoria e aumentar, consequentemente, o tempo de trabalho excedente da jornada de trabalho (mais-valia relativa). Esta ü1tima alternativa supõe, necessariamente, uma mudança na com posição orgânica do capital, ou seja, um maior emprego de cá pital constante em relação ao capital variảvel.

A acumulação do capital implica a concentração de meios de produção e do poder de mando sobre o trabalho nas mãos de capitalistas individuais que competem entre si. Mas se expressa, tambẻm, na expropriação dos capitalistas menores em um movimento de atração de capitais jă existentes, isto é, em um movimento de centralização do capital. (51)

Ao desenvolver-se o processo de acumulação, o incremento de produtividade do trabalho torna-se a sua alavan ca mais poderosa. Essa produtividade aumentada do trabalho se expressa no fato de que um capital necessita menos trabalho necessärio para produzir um mesmo valor de troca, ou quantida des maiores de valor de uso. Ou seja: um mesmo capital põe em movimento mais sobretrabalho e menos trabalho necessário. Des sa forma, todos os métodos de potenciação da força de traba1ho são métodos de incrementar a produção de mais-valia, elemento constitutivo da acumulação. A lei do capital é criar so bretrabalho, o que supõe a mediação do trabalho necessário co mo condição de extrair aquele. Sua tendência é criar a maior

(51) Sobre a concentração e centralização do capital, ver K. Marx. E1 Capital. Crítica de la Economía Política, op. cit., t. I, cap. XXIII, p. 528-32. 
quantidade possivel de trabalho materializado, isto $\vec{e}$, de va lor, e ao mesmo tempo, reduzir o tempo de trabalho necessärio à reprodução da força de trabalho a um mínimo, ampliando o tempo de trabalho excedente. O grau social da produtividade do trabalho reflete-se numa diminuição relativa da massa de trabalho face à massa dos meios de produção que absorve. Portanto, à medida que progride a acumulação, a tendência é a re dução do capital investido na compra e venda da força de trabalho, em proporção ao capital total empregado na produção: não é uma redução absoluta, mas relativa ao aumento do capital constante. Como a demanda do trabalho depende do capital variảvel e não do capital total, esse tende a se reduzir, relativamente ao crescimento do capital investido no conjunto do processo produtivo. Assim, para ser possível manter os tra balhadores empregados e manter o contingente dos ativos, è ne cessärio um ritmo cada vez mais acelerado de acumulação de ca pital. Esse descenso relativo do capital variável expressa-se como um crescimento absoluto da população trabalhadora, mais räpido que os meios de ocupação que o capital oferece, dando origem a uma superpopulação relativa face às necessidades mê dias do capital ou "exército industrial de reserva". Essa população sobrante faz com que a produção capitalista possa de senvolver-se livre de limites que se lhe possam opor o cresci mento natural da população.

"Portanto, ao produzir a acumulação do capital, a população trabalhadora produz, tambem em proporções cada vez maiores, os meios para o seu excesso relativo. Esta è a lei de populaçäo peculiar do regime de produção capitalista, pois em realidade, todo regime histörico con creto de produção tem suas leis de população prôpriasleis que regem de um modo historicamente concreto."(52)

(52) K. Marx. El Capital. Crítica de la Economía Política, op. cit., t. I. cap. XXIII, p. 534 (Grifos do autor). 
Contraditoriamente, portanto, a classe traba lhadora, ao fazer crescer a lucratividade da classe capitalis ta, reduz as possibilidades de obter os meios de vida do conjunto da população trabalhadora, $j a ̈$ que, neste mesmo processo em que cria riquezas para outros, cria também as condições pa ra que se reproduza uma parcela de população excessiva para as necessidades médias do capital, isto ê, em proporção à intensidade e extensão do processo de acumulação.

o exército industrial de reserva, sendo um pro duto da acumulação, è, também, uma das condiçöes para que esta se efetive. A existência de uma superpopulação trabalhadora disponível, independente dos limites reais de crescimento da população, é condição fundamental para a vida do pröprio regime do capital. Isto porque, à medida que cresce a força expansiva do capital face à produção em grande escala, aumenta o ritmo da acumulação, a transformação acelerada do produto excedente em novos meios de produção. A existência de gran des massas de trabalhadores disponíveis a serem imediatamente absorvidas, sem que a escala de produção em outras örbitas se ja afetada, $\vec{e}$ condição para que o processo de acumulação ampliada se renove. Essa massa de trabalhadores é oferecida à indústria pela existência de uma população excessiva colocada em disponibilidade, devido a mëtodos de produção que diminuem, proporcionalmente, a cifra de trabalhadores face à ampliação da mesma produção. (53)

(53) "Constitui un exército industrial de reserva, um contingente dispoñivel que pertence ao capital de modo tão absoluto como se tivesse sido criado e se mantivesse às suas custas. Oferece-lhe o material humano, disposto a ser sempre explorado, à medida que o exijam suas necessidades variäveis de exploração e, alem disso, independente dos limites que o aumento real da população lhe possa opor." K. Marx. El Capital. Crítica de la Economía Política, op. cit., t. I, cap. XXIII, p. 535. 
0 desenvolvimento das forças produtivas sociais do trabalho permite ao capitalista, com o mesmo desembolso de capital variāvel, colocar em ação maior quantidade de trabalho, mediante maior exploração intensiva e extensiva de forças de trabalho individuais. Esse excesso de trabalho de trabalhadores ativos tem como contrapartida o engrossamento das filas dos trabalhadores em reserva, ao mesmo tempo em que a pressão destes sobre aqueles obriga-os a trabalharem mais e a se submeterem às pressões do capital. (54)

0 crescimento cäclico da indüstria moderna, as necessidades de expansão e retração do capital funcionam como um dos agentes mais ativos do exercito industrial de reserva.

O movimento geral de salärios passa a ser regu lado, em termos gerais, pelas expansões e contraçōes da população trabalhadora sobrante, correspondentes às alternativas periódicas do ciclo industrial: se durante as fases de expansão econômica o exército industrial de reserva exerce uma pressão sobre os trabalhadores ativos, nos momentos de superprodução e crise, funciona como freio às suas exigências. Atua como uma pressão baixista dos salärios e favorecedora da subordinação do exército ativo às imposições do capital na sua fome insaciäve1 de absorção de trabalho não pago. Assim, a existência da superpopulação relativa $\overrightarrow{\mathrm{e}}$ o pano de fundo a par tir do qual se move a lei da oferta e demanda de trabalho, em condições absolutamente favoräveis ao capital, no regime espe cificamente capitalista da produçāo.

(54) "A existência de um setor da classe trabalhadora condenado à ociosidade forçada, pelo excesso de trabalho imposto à outra parte, converte-se em fonte de riqueza do capitalista individual e acelera, ao mes mo tempo, a formação do exército industrial de reserva em uma escala prô porcional aos progressos da acumulação social." K. Marx. "El Capital. Crítica de 1a Economía Política, op. cit., t. I, cap. XXIII, p. 539. 
Esta população sobrante se apresenta sob diver sas modalidades. (5ㅗ) Nos centros industriais modernos, a pro dução ora atrai um nümero maior de trabalhadores, ora os repe le. O nümero de trabalhadores empregados aumenta em termos ge rais, ainda que em proporções decrescentes à escala de produção. A superpopulação existe em um estado flutuante. Com o avanço de divisão técnica do trabalho dentro do processo produtivo, o capital tende a absorver parcelas de classe trabalhadora até então não integradas na produção: jovens e mulheres especialmente. (56) Com a intensificação do processo de exploração do trabalho a vida média do trabalhador se reduz; o processo de envelhecimento se acelera. Tais condições exigem uma râpida reprodução das gerações trabalhadoras.

Mas a expansão da acumulação do capital não $\vec{e}$ linear: vai abarcando progressivamente diversos ramos de produção. Ao atingir a agricultura, tende a reduzir a demanda da população trabalhadora rural, sendo que esta expulsão não ë completada, como na indústria, por um movimento de nova absor ção. Uma das alternativas que se afigura à população è a migração para os centros urbanos. O fluxo para as cidades supõe, no campo, a existência de uma superpopulação latente constante.

(55) Sobre as modalidades da superpopulação trabalhadora, que aqui mencionaremos de modo sucinto, ver K. Marx. El Capital. Crítica de la Economía Política, op. cit., t. I. cap. XXIIT, item 4: "Diversas modalidades de superpopulaçáo relativa. A lei geral da acumulação capitalista", p. 543-9.

(56) "O fato de que o incremento natural da massa trabalhadora não sacie as necessidades de acumulação do capital e, apesar disto, as rebai $x e, \vec{e}$ uma contradição inerente ao prōprio processo capitalista. 0 capí tal necessita grandes massas trabalhadoras de idade jovem e menores proporções de idade adulta. Esta contradição não ê menos escandalosa que aquela que supõe a queixa de falta de braços em un momento que estão lan çados à rua milhões de homens, porque a divisão do trabalho os vincula $\bar{a}$ um determinado ramo industrial." K. Marx. El Capital. Crítica de la Economía Política, op. cit., t. I, cap. XXIII, p. 543. 
Existem ainda aquelas camadas de classe traba1hadora do exército ativo que vivem de trabalho muito irregular. E a chamada superpopulação intermitente, cujo nível de vida encontra-se abaixo da média da classe trabalhadora.

Finalmente, excluindo o "lumpen proletariado", encontra-se a camada social dos trabalhadores que vivem numa situação de pauperísmo, $\underline{(57)}$ constituída não sö de pessoas capacitadas para o trabalho (cuja proporção aumenta nos períodos de crise e se reduz nas fases de "euforia econômica"), como também de órfãos e filhos de pobres que são envolvidos no exército ativo nos períodos de pico econômico e, ainda, os velhos e as "vítimas da grande indústria": viưvas, mutilados, doentes.

Importa marcar que, quanto maior é o crescimen to econômico, isto é, a acumulação, naior também é o contingente absoluto do proletariado e a capacidade produtiva de seu trabalho; e tanto maior é o exército industrial de reserva. Este cresce ao crescer a riqueza social. (묘)

(57) "O pauperismo é asilo dos invälidos do exêrcito trabalhador ati vo e peso morto do exército industrial de reserva. Sua existência levā implícita a existência de uma superpopulação relativa, sua necessidade a necessidade desta e com ela constitui uma das condições de vida da produ ção capitalista e da produção de riqueza. Figura entre as "faux fraix" de produção capitalista (...)" K. Marx. El Capital. Crítica de 1a Economía Política, op. cit., t. I, cap. XXIII, p. 545-6.

(58) "Quanto maiores são a riqueza social, o capital em funcionamento, o volume e a intensidade de seu crescimento e maiores também, portan to, a magnitude absoluta do proletariado e a capacidade produtiva do seu trabalho, tanto maior é o exército industrial de reserva. A força de trabalho disponivel se desenvolve pelas mesmas causas que a força expansiva do capital. A magnitude relativa do exército industrial de reserva cresce, consequentemente, à medida que crescem as potências de riqueza. E quanto maior é este exército de reserva em proporção ao exército ativo, mais se estende a massa da superpopulação considerada, cuja miséria se acha em razão inversa aos tormentos de seu trabalho. E finalmente, quanto mais crescem a miséria dentro da classe trabalhadora e o exército industrial de reserva, mais cresce o pauperismo oficial. Tal é a lei geral absoluta da acumulação capitalista." K. Marx. E1 CapitaI. Critica de Ia Economía Política, op. cit., t. I, cap. XXIII, p. 546 (Grifos do autor): 
O capital mantém sempre a superpopulação relativa em proporção às suas necessidades de acumulação.

A reprodução ampliada do capital é acompanhada não sō de uma reprodução ampliada das relaçöes de classes, à proporção que o proletariado absoxvido pelo capital se expande; mas esta reprodução da relação social $\bar{e}$ tambèm uma reprodução dos antagonismos de classe que tendem a se aprofundar. A acumulação da misēria è proporcional à acumulação do capital.

"A produção capitalista não ë só reprodução da relação; é sua reprodução numa escala sempre crescente, e, na mesma medida em que, com o modo de produção capitalista se desenvolve a força produtiva social de trabalho,cres ce tambëm frente ao trabalhador a riqueza acumulada, cō mo riqueza que o domina, como capital (...) e na mesma proporção se desenvolve por oposição sua pobreza, indigência e sujeição subjetiva." (59)

No mundo das aparências, esta realidade, qúe aqui se busca desvendar, apresenta uma outra face: para o capitalista o capital è uma soma de meios materiais de produção que tem o poder místico de gerar mais capital; o trabalho não pago extraído da classe trabalhadora, que $\vec{e}$ a fonte de rique$z a$ do burguês e da miséria do proletärio, aparece, exclusivamente, como trabalho pago atravës do salário. Para a classe capitalista a fonte de seu lucro não provém de : expropriação da vida humana da classe trabalhadora mas, sim, de um mero me canismo de mercado: comprar mais barato e vender mais caro. A fonte de seu 1ucro, na sua consciência aderida ao capital,pro vëm da circulação. O capital acrescido, expresso num produto que é uma mercadoria, tem que ir ao mercado, para este valor valorizado se realizan, transformando-se novamente em dinheiro, que é a forma necessäria para se reiniciar o ciclo produtivo. Este processo que se expressa numa mudança meramente formal do valor capital é falsamente qualificado como a fonte de riqueza. p. $10 \overline{3}$.

(59) K. Marx. El Capital, libro I, capítulo VI (Inẻdito), op. cit., 
- limite mínimo do preço de venda da mercadoria produzida e o seu preço de custo, que significa, para o capitalista, o necessário para repor o capital invertido na produção: o valor dos meios de produção consumidos e o preço da força de trabalho. O preço de custo repõe o que a mercadoria custou ao capitalista, sendo medido pela inversão do cap ta1. Desta forma, o custo capitalista não expressa todo o valor da mercadoria ou o seu preço real de custo, porque este inclui, além da reposição do capital adiantado, uma parte do valor contido na mercadoria, o qual nada custou ao capitalista -- a mais-valia -- mas que custou ao trabalhador como trabalho não retribuído. Porém, o capitalista não pensa a partir do valor da mercadoria, mas sim de seu preço de custo; não pensa em termos de mais-valia e sim de lucro. o lucro é a for ma transfigurada da mais-valia na qual se encobre o segredo de sua existência e a sua origem: mas é uma das formas em que a mais-valia se manifesta. $\underline{(60)}$ Mas se até aqui nos referimos fundamentalmente à mais-valia, o que é o lucro? A mais-valia, considerada como o remanescente do capital total invertido na produção, assume a forma de 1 ucro. (61) Enquanto a taxa de mais-valia ou de exploração do trabalho é medida em relação ao capital variāvel, ou seja, è a relação entre trabalho pago e não pago, na taxa de lucro o trabalho não pago é calculado em relação ao capital total adiantado na produção. Na taxa de

(60) K. Marx. El Capital. Crítica de la Economía Política, op. cit., t. IIT, cap. II, p. 63

(61) "Assim representada, como "rebento" do capital total desembolsa do, a mais-valia reveste a forma transfigurada de lucro (...) Consequen= temente, o lucro (...) é o mesmo que a mais-valia, ainda que sob uma for ma mistificada, a qual responde, necessariamente, ao regime de produção capitalista $(. .$.$) Ao aparecer o preço da força de trabalho, em um dos$ pólos, sob a forma transfigurada de salärio, a mais-valia aparece em outro pồlo, sob a forma transfigurada de lucro (...)" K. Marx. El Capital. Crítica de la Economía Política, op. cit., t. III, cap. I, p. 53.

"A mais-valia ou lucro consiste no remanescente do valor da mercadoria sobre o seu preço de custo, isto é, no remanescente da soma total de trabalho contido na mercadoria depois de cobrir a soma de trabalho retri buído que ela encerra (...)" K. Marx. El Capital. Crítica de la Economía Política, op. cit., t. III, cap. I. p. 58. 
mais-valia se desnuda a relaçäo capital e trabalho; na taxa de lucro, as diferentes "funçōes" que cumpre o capital invertido nos meios de produção e na força de trabalho se obscurecem, jả que se trata de considerar o capital total de maneira indiferenciada; consequentemente, o capital aparece numa rela ção consigo mesmo. Existe a a consciência de que o valor novo é gerado pelo capital ao longo do processo de produção e circulação. Porẻm, o modo como isto ocorre aparece mistificado como fruto de qualidades inerentes ao próprio capital. Mas, se a mais-valia nasce no processo direto de produção, so se realiza no process de circulação. o fato de realizar-se ou não e o grau em que este valor excedente se realiza dependem das condições do mercado, da concorrência, isto é, da mútua especulação entre os capitalistas. Assim sendo, a mais-valia ou lucro jä não aparece como produto da apropriação de tempo de trabalho nãa pago, mas sim como o remanescente do preço de venda sobre o preço de custo. Como o capitalista identifica o preço de custo com o valor intrínseco da mercadoria, o lucro para ele só pode provir da circulação. (62) Não percebe que seu lucro sö pode originar-se do fato de poder vender algo pe 10 qual nada pagou. Esta aparência de que a mais-valia ou lucro, além de realizar-se na circulação, dela brotasse diretamente é realçada pelo menos por dois fatores: o lucro obtido na venda depende das conjunturas de mercado, alēm da astücia e do conhecimento do capitalista; por outro lado, entra em jo go, alēm do tempo de produção, o tempo de circulação, pois quanto menor $\vec{e}$ o período em que a mercadoria permanece no me $\underline{r}$ cado ou, em outros termos, quanto mais räpida é a venda,maior é a rotatividade do valor capital e maior a acumulação.

(62) "O remanescente do valor ou mais-valia que se realiza ao vender a mercadoria é considerado pelo capitalista, portanto, como o remanescen te de seu preço de venda sobre o. seu valor e não como un remanescente dé seu valor sobre o seu preço de custo, como se a mais-valia contida na mercadoria não se realizasse mediante a venda, mas surgisse diretamente dela." K. Marx. El Capital. Crítica de Ia Economía Polîtica, op. cit., t. III, cap: I, p. 54 . 
Este processo mistificador adquire novos mati zes e complica-se, ainda mais, ao se considerar o lucro médio e os preços de produção. $(53)$

2.4. A Reprodução do Capital e a Totalidade da Vida Social

Ao finalizar estas reflexões, importa destacar alguns aspectos $j \vec{a}$ abordacos no decorrer da exposição, mas que, reunidos, explicitam melhor a dimensão de totalidade do processo de produção e reprodução das relações sociais, ou seja, como a reprodução do capital permeia as värias "dimensões" e expressões da vida em sociedade.

A produção e reprodução da riqueza material, inseparävel da criação e recriaçăo ăas formas sociais de que se reveste $\vec{e}$ um processo eminentemente social. Eindissociāvel das relações sociais que na era do capital têm como agentes fundamentais os capitalistas e trabalhadores assalariados, considerados não apenas individualmente, mas como representan tes de classes sociais antagônicas. (64) 0 antagonismo de in(63) Sobre esta questão, ver K. Marx. El Capital. Crítica de la Ecomía Politica, op. cit., t. III, seção Il, p. 150-212.

(64) Faz-se necessärio esclarecer que, embora a reflexão expressa nes sa primeira parte tenha se centralizado em torno do capital e trabalho assalariado, tal não significa um desconhecimento da importāncia da propriedade privada da terra e da classe dos proprietärios de terra que se apro priam de parcela da mais-valia socialmente gerada, sob a forma de renda da terra. A centralização da anâlise em torno do capital como relação burguesa de produção tem as suas justificativas. Emprimeiro lugar, por ser a relação determinante dá atual forma de organização social da produção, a partir da qual as demais adquirem inteligibilidade. E sua compreensäo que desvenda a produçāo e extração da mais-valia, que constitui o motor e a finalidade bäsica da produçăo nesta fase histórica. A renda da terra não é mais que outra forma transfigurada de se expressar a mais-valia que, como o lucro, tem como tal suas características específicas. Em segundo lugar, como o propósito desta exposição é subsidiar a discussão da profissão de Serviço Social, situando-a no processo de reprodução, esta se nos afigura como sendo um fenomeno tipicamente urbano-industrial. Embora isto não elimine a importância da compreensão da classe dos proprietários de terra, especialmente face à realidade latino-americana, não se trata de uma condição indispensável para a fundamentação das hipóteses de trabalho referentes à inserção da profissão no movimento contraditório da vida social. Dentro das limi tações dopresente trabalho, cremos que as colocações apresentadas são suficientes (mas não exaustivas) para os propósitos em vista. 
teresses que permeia tais relaçices, independente das elabora çôes ideolögicas que se faça dos mesmos, 已 um fato objetivo, dado pelo caräter cada ve $z$ mais social da produção contraposto à apropriação privada dos meios e dos produtos do trabalho alheio. Em outros termos, a lei geral da acumulação supõe a acumulação da riqueza, monopolizada pox uma parte da sociedade -- a classe capitalista - inseparävel da acumulação da mi séria e da pauperização daqueles que produzem a riqueza como uma riqueza alheia, como poder que os domina, enfim, como capital.

A reprodução ampliada do capital supõe a recriação ampliada da classe trabalhadora e do poder da classe capitalista e, portanto, uma reprodução ampliada da pobreza e da riqueza e do antagonismo de interesses que permeia tais re I̊ções de classes, o qual se expressa na luta de classes.

Nesse mesmo processo de reprodução da dominação, são criadas as bases materiajs para uma nova forma de or ganização da sociedade. A sociedade capitalista, expressão histôrica do desenvolvimento social e, portanto, necessäria à expansão das forças produtivas do trabalho social, encontrase em processo de recriação e de negação. O mesmo processo que a recria, reproduz os seus antagonismos.

Do ponto de vista da população trabalhadora, este processo se expressa numa pauperização crescente em rela ção ao crescimento do capital. Não se trata, necessariamente, de pauperização absoluta, mas relativa à acumulação do capital, que atinge a globalidade da vida da classe trabalhadora. A exploração se expressa tanto nas condições de saüde, de habitação, como na degradação moral e intelectual do trabalhador; o tempo livre do trabalhador è cada vez menor, sendo absorvido pelo capital nas horas extras de trabalho, no trabatho noturno que desorganiza a vida familiar. Operíodo da infância se reduz pelo ingresso precoce de menores na atividade produtiva. As mulheres tornam-se trabalhadoras produtivas. 
Crescem, junto com a expansão dos equipamentos e máquinas mo dernas, os acidentes de trabalho, as vítimas da indústria. 0 processo de industrialização, ao atingir todo o cotidiano do operärio, transforma-o num cotidiano de sofrimento, de luta pela sobrevivência. Esta luta pela sobrevivência se expressa tambẻm em confrontos com o capital, na busca de reduzir o pro cesso de exploração, com vitórias parciais, mas significati vas da classe trabalhadora, como a jornada de oito horas de trabalho, a legis lação trabalhista, o sindicalismo livre, etc. A classe capitalista, zelosa de seus interesses, cuida para que as conquistas da classe trabalhadora não afetem visceralmente a continuidade da vida do capital. (65)

Vemos, portanto, que a reprodução das relações sociais é reprodução da dominação: reprodução ampliada do domínio de classe. Este é um processo eminentemente polit co, em que as classes dominantes têm no Estado o instrumento privilegiado do éxercício de seu poder no conjunto da socieda de.

Mas, concomitantemente à reprodução da domina ção, recriam-se, tambëm, as formas sociais mistificadas que encobrem a exploração. Têm por função apresentar a desigualda de entre classes como normais, naturais, destituídas de conflitos e contradiçöes. Estas formas ideológicas são as aparên cias atravês das quais as relações sociais antagônicas se manifestam. A produção e reprodução da ideologia ê fruto do mes

(65) "A lei da acumulação capitalista que se pretende inistificar, convertendo-a em lei natural, não expressa mais que uma coisa; que sua natureza exclui toda redução do grau de exploração do trabalho ou toda alta do preço desde que possa colocar em perigo seriamente a reprodução constante do regime capitalista e a reprodução do capital em uma escala cada vez mais alta. E, forçosamente, tem que ser assim em um regime de produção em que o trabalhador exis te para as necessidades de exploração de valores ja criados, em vez da riqueza material existir para as necessidades do trabalhador." K. Marx. El Capital. Crítica de la Economia Política, op. cit., t. I, cap. XXIII, p. 524. 
mo processo em que se reproduz a riqueza social como capital e o trabalho como trabatho assalariado. Porém, se as formas ideolögicas encobrem a exploração, näo a eliminam: ambas são produto contraditório do mesmo processo histörico, configuran do-o como um "desenvolvimento histörico desigual". (66) As ideologias que se reproduzem na prätica cotidiana são também absorvidas pela "ciência" ou pelos intelectuais "orgânicos" das classes dominantes. Como sustentam Marx e Engels:

"As idéias (Gedanken) da classe dominante são, em ca $\mathrm{da}$ época, as ideias dominantes, is to $\overline{\mathrm{e}}$, a classe quēe é a força material dominante é, ao mesmo tempo, sua força espiritual dominante. A classe que tem à sua disposição os meios de produção materiais, tem ao mes mo tempo os meios de produção espiritual, o que faz com que a ela sejam submetidas, ao mesmo tempo e, em média, as idéias daqueles a que faltam os meios de produção espiritual. As idéias dominantes não são mais que a expressäo ideal das relações materiais dominantes concebidas como idéias; portanto, a expres são das relações que tornam una classe a classe dominante; portanto, as idëias de sua dominaçăo. Os incti= víduos que constituem a classe dominante possuem, en tre outras coisas, também consciência e, por isto,pen sam; na medida em que dominam como classe e determi nam todo o ambito de una época histörica, é evidente qque o façam em toda a sua extensão e, consequentemente, entre outras coisas, dominem também como pensadores, como produtores de idéias; que regulem a produção e distribuição de idêias de seu tempo e que suas idéias sejam, por isso mesmo, as idéias dominantes da epoca. (67)

Deve-se ainda, apenas marcar que o processo de produção capitalista não é só um processo de re-produção de relações sociais, mas de produção de relaçöes. Enquanto as relações sociais se renovam em alguns ramos produtivos, a expansão da acumulação vai abrangendo novos ramos,. provocando

(66) Esta noção de desenvolvimento histórico desigual, assim compreendida é desenvolvida por José de Souza Martins, no conjunto de seus trabalhos, conforme indicação bibliogräfica.

(67) K. Marx e F. Engels. A Ideologia alemã (Feuerbach). Säo Paulo. Grijalbo, 1977. p. 72 . 
alterações substanciais na maneira de produzir, ou seja, no processo técnico de trabalho e nas relações sociais de produção, face à subsunção real do trabalho ao capital. Porëm, a expansão do capital não é linear. Verifica-se, historicamente, que o movimento mesmo de reprodução no conjunto da sociedade produz relações sociais de produçäo näo capitalistas, como meio de extração de trabalho excedente pelo capital. Não se trata de mera sobrevivência de relações pröprias de modos anteriores de organização da sociedade, porque são redimensiona dos no seu significado histórico ao se subordinarem ao moví mento expansionista do capital. Trata-se da produção capitalista de relações de produção não capitalistas. $\underline{(68)}$

Finalizando este capítulo, importa explicitar o raciocínio que norteou sua elaboração. O esforço efetuado orientou-se no sentido de articular, na exposição, teoria e mëtodo. A explicitação das noções fundamentais que conformam o universo analítico da pesquisa $\vec{e}$ condição preliminar para o tratamento teórico do tema em estudo. Procurou-se resgatar e acentuar, no decorrer da exposição efetuada, alguns princípios metodológicos do pensamento de Marx, assim como a dimensão propriamente sociolögica de sua reflexão, procurando fa zer face às leituras correntes, de cunho economicista do autor. Embora limitadamente, aventurou-se na busca de explicitar as tensões inerentes e específicas às relações sociais que peculiarizam a sociedade do capital: a articulação indissolúvel e contraditôria entre a essência dessas relações sociais e sua manifestação atravês das formas sociais, por meio das quais se expressam, ambas engendradas e recriadas no processo da vida social. Acentuamos a tensão entre a aparência de rela

(68) Não se pode encarar relações como o escravismo, a produção mer cantil simples, o "colonato", etc., como excrescências no capitalismo, mas como maneiras historicamente específicas do capital se reproduzir. Sobre a questão ver o original trabalho de José de Souza Martins. $\underline{0}$ Cativeiro da terra. São Paulo, Ciências Humanas, 1979. 
ções igualitárias, indispensável à troca de mercadorias equi valentes, expressa na örbita da circulação, e a desigualdade inerente a esse modo de produção e de vida, em que o caráter cada vez mais social do trabalho contrapōemse à apropriação privada das condições e produtos do mesmo. Ressaltamos ainda, como a "1iberdade" do trabalhador, necessäria ao intercâmbio de sua capacidade de trabalho como mercadoria, contrapõe-se, contraditoxiamente, à reprodução das condições de sua dominação e de sua misëria. Ou seja, procuramos explicitar como o próprio processo de exploração produz a sua legitimação. Esse descompasso necessário ao funcionamento da sociedade só pode ser superado através da prática política.

A força de trabalho em ação, sendo a substân cia que produz a riqueza, a reproduz como riqueza para outros. Assim, o trabalho se torna para o trabalhador como algo que the ë estranho, que o mortifica e no qual se aliena, mas atravës do qual são, tambëm, gestadas as condições de sua efeti va libertação. A própria organização do processo de produção, entendido como unidade contraditöria de produção, circulação, troca e consumo, viabiliza as ilusões que conferem à circulação, a qualidade de criadora de sobrevalor, independente da produção. Por outro lado, a mística da forma salário encobre, ao mesmo tempo em que permite desvendar, a relação entre o trabalho pago e não pago do trabalhador. Essas mistificações afetam não só aos capitalistas, mas também à classe trabalhadora.

Esses, dentre outros, foram alguns aspectos que se procurou acentuar, descartando a perspectiva analítica, que, em detrimento da apreensão do movimento contraditório da totalidade concreta, enquadra a realidade em niveis analíticos: econômico, político e ideolögico. Enfim, procurou-se dar alguns passos, ainda que limitadamente, no sentido de captar o desenvolvimento desigual entre as representaçōes 
e a realidade substancial dos fenômenos, ressaltando as media ções necessārias à expressão đas contradições e as determina ções do processo social na sua totalidade. 
O Serviço Social sô pode afirmar-se como prätí ca institucionalizada e legitimada na sociedade ao responder a necessidades sociais derivadas da prätica histörica das classes sociais na produção e reprodução dos meios de vida e de trabalho de formá socialmente determinada.

A medida que a satisfação das necessidades so ciais se torna mediatizada pelo mercado, is to $\vec{e}$, pela produção, troca e consumo de mercadorias, tem-se uma crescente divisão do trabalho social, a qual pode ser considerada nas suas formas gerais (no mercado mundial, por grupo de países, no interior de um país, entre agricultura e industria, cidade e campo, etc.), passando pelas formas singulares e particulares dentro dos ramos de produção, atê a divisão do trabalho no interior da oficina. (I)

(1) Sobre a divisão do trabalho, ver especialmente: K. Marx e F. Engels. A Ideologia..., op. cit.; K. Marx. El Capital. Crítica de la Economia política, op. cit., t. I, seção IV; idem. La Miseria de la Filosofia. Buenos Aires, Siglo XXI, 3a. ed. p. 104-28; Idem. 'Manuscritos economicofilosóficos de 1848", op. cit., p. 99-104; Idem. Los Fundamentos de la Crítica de la Economia Política. v. II . Madri, Comunicaciōn, 1972 . p. 55573; F. EngeIs. Do Socialísmo Utopico ao Socialismo Científico. Lisboa.Ed. Estampa, 1971. E ainda: H. Braverman. Trabalho e Capital Monopolista. A Degradação do trabalho no século XX. Rìio de Janeiro, Zahar, 1977; H. LeFebvre. "A Sociologia...", op. cit., p. 64-88; A.Gorz (org.) Critica da divisão do trabalho. Sao Paulo, Martins Fontes, 1980. 
A divisão do trabalho na sociedade determina a vinculação de individuos en örbitas profissionais específicas, tão logo o trabalho assume um caráter social, executado na so ciedade e atravês dela. Com o desenvolvimento das forças pro dutivas sociais do trabalho, sob a égide do capital, o proces so de trabalho passa a ser efetuado sob a forma de cooperação de muitos trabalhadores livres e de máquinas no interior da fáa brica. Verifica-se, ao mesmo tempo, um parcelamento das ativi dades necessārias à realização de um produto, sem precedentes em ëpocas anteriores, agora executados por diversos trabalha dores diferentes e por um sistema de máquinas. Cria-se o tra balhador parcial, efetuando-se o parcelamento do pröprio indi víduo no ato da produção. As forças produtivas do trabalho co letivo são apropriadas pelo capital, enfrentando o trabalhador como elementos que o subjugam. A pröpria ciência ë apropriada pela classe capitalista e colocada a seu serviço, como força produtiva do capital e não do trabalho.

Eneste contexto da divisäo social do trabalho que se pretende situar o Serviço Social. Esta è uma linha de análise que não encontra suporte na literatura brasileira es pecializada do Serviço Social e da sociologia das profissões, implicando em reunir alguns elementos teöricos complementares que permitam, nos capitulos subsequentes, caracterizar a pro fissão face à divisão de trabalho peculiar à sociedade capita lista.

A divisão do trabalho na sociedade, isto ê, a divisão social do trabalho e a consequente determinação dos individuos a certos ramos de atividades profissionais $\vec{e}$ uma característica comum a todas as sociedades. Interessa, no en tanto, circunscrever a presente análise a partir do momento em que a troca de mercadorias passa a ser o agente intermedia rio da articulação de trabalhos diferenciados, oriundos de ó $\underline{r}$ bitas distintas da produção. Partimos, pois, da divisão do trabalho tal como se configura na produção e circulação sim 
ples de mercadorias, percorrendo a manufatura, para explicitar as peculiaridades dessa divisão no interior da sociedade e da produção características da indústria capitalista. Ressalta-se a importância de apreender a historicidade dessa no ção, ou seja, de compreender as diversas formas específicas que a divisão do trabalho assume, de acordo com as condições de produção sobre a qual se baseia e asrelações entre os membros da sociedade que refletem a realidade dessas condições. (2)

3.1. Fundamentos da Divisão do Trabalho.

Ao produzirem os meios de vida, os homens pro duzem sua vida material. 0 modo de produzir os meios de vida refere-se não só à reprodução física dos indivíduos, mas à reprodução de determinado modo de vida. A produção da própria vida no trabalho e da alheia na procriação dä-se numa dupla relação natural e social; social no sentido de que compreende a cooperação de muitos indivíduos. Portanto, determinado modo de produzir supõe, tambëm, determinado modo de cooperação entre os agentes envolvidos, determinadas relações sociais esta belecidas no ato de produzir, as quais envolvem o cotidiano da vida em sociedade. ( 3 )

o grau de desenvolvimento da divisão social do trabalho expressa o grau de desenvolvimento das forças produtivas sociais do trabalho. Com a divisão do trabalho dá-se,ao mesmo tempo, a disthibuição quantitativa e qualitativa do pró prio trabalho e dos seus produtos, isto é, da propriedade -- do poder de dispor do trabalho de outros. A divisão do tra

(2) K. Marx. Los Fundamentos de la Crïtica de la Economía Política, op. cit., p. 561 .

(3) "Tai como os indivíduos manifestam sua vida, assim são eles. 0 que eles são coincide, portanto, com sua produção: com o que produzem, com o modo como produzem. O que os indivíduos são depende, pois, das condiçōes materiais de produção." K. Marx e F. Enge1s. A Ideologia Alemã. (Feuerbach). São Paulo, Grijalbo, 1977. p. 27-8. 
balho e a propriedade são expressões idênticas: o que a primeira enuncia em relação à atỉidade do homem, a segunda enun cia em relação ao produto da atividade do homem. Assim é que a cada fase da divisão do trabalho corresponde uma forma de propriedade, ou a cada estágio do desenvolvimento das forças produtivas do trabalho social corresponde uma forma de apropriação do trabalho. (4)

Sendo o trabalho humano expressão da atividade humana num contexto de alienação, a "divisão do trabalho é a expressão econômica do carâter social do trabalho dentro da a1ienação". (ㅁ)

Os sujeitos do processo de troca aparecem como proprietários de mercadorias sendo a propriedade privada con dição prévia da circulação. A apropriação da mercadoria não se efetua na circulação, mas deve ser suposta anteriormente. $\mathrm{Na}$ produção simples, a mercadoria tem como fonte o trabalho de seu possuidor. Como valor de troca, ê trabalho materializa do; a expressão do indivíduo produzida por ele e objetivada para outro. Nesse contexto, o trabalho e a apropriação pelo individuo sobre os frutos de seu próprio trabalho servem de ba se à apropriação do trabalho de outros na esfera da circula ção. Isto supõe a alienação ou conversão do trabalho pessoal em uma forma social. A circulação é, portanto, o movimento me diante o qual o produto pessoal se converte em produto social, em valor de troca expresso no dinheiro, para logo reconver ter-se em produto individual, ou seja, em valor de uso e obje to de consumo para o próprio indivíduo. Assim o conjunto do

(4) Ver K. Marx e F. Enge1s. A Ideologia...., op. cit.

(5) "Una vez que o trabalho humano năo ê mais que a atividade humana dentrō da alienação -- da manifestação da vida enquanto alienação da vi da - podemos dizer, tambêm, que a divisão do trabalho não ê outra coisā que o estabelecimento alienado da atividade humana genérica real ou da atividade do homem enquanto ser genêrico". K. Marx. "Manuscritos econômico-filosöficos de 1848." In: K. Marx e F. Engls. Manuscritos econômicos värios. Barcelona, Grijalbo, 1975. p. 99. 
processo de troca implica como prë-condição, que a produção esteja submetida à divisão do trabalho social. rsso porque "as mercadorias trocadas são trabalho objetivado em diversos valores de uso que representam o modo de existência objetivado da divisão do trabalho ou da materialização de trabalhos qualitativamente diferentes que satisfazem um conjunto de necessidades diferentes". (ㅁ) Porểm a consideração da divisão do trabalho não se esgota na ótica do intercâmbio de trabalhos de qualidades diferenciadas, do ponto de vista do valor de uso dos produtos trocados. No mundo dominado pelo valor de troca, o individuo produz para si ao produzir para a sociedade, na qual cada membro trabalha para ele em outra esfera. Ao se produzir uma mercadoria esta deve ter um valor de uso não para quem a produz, mas para outros; è valor de troca, que só se converte em meio de subsistência para seu produtor depois de ter revestido, no dinheiro, a forma de produto universal, atravês do qual pode realizar-se em qualquer trabalho de outro qualitativamente distinto. Implica, uma forma especifica da divisão do trabalho, cuja condição fundamental é que os su jeitos criem produtos determinados pelo elemento social do valor de troca. Trata-se da divisão do trabalho de estrutura histôrica determinada na qual o indivíduo se encontra determi nado pela sociedace. Quancio o inaividvo produz seus pröprios meios de subsistência, sua produçăo não tem um carăter social e seu trabalho não ê social. Este caräter social sö se manifesta no conteudo do trabalho, quando, como membro de um complexo social, produz para as necessidades dos demais, estando submetido a uma dependência social. Seu trabalho privado torna-se trabalho geral e seu produto um produto social que res ponde a necessidades sociais. Tal se comprova pelo fato de que seu trabalho privado passa a constituir uma particularida de do trabalho social, um ramo que o completa, um modo de existência do trabalho coletivo. Nesse contexto os individuos

(6) K. Marx. Los Fundamentos..., op. cit., p. 559. 
se enfrentam unicamente na qualidade de proprietários de valo res de troca. Os laços sociais entre os indivíduos deixam de ter a característica de laços diretos entre membros de uma comunidade, para se tornarem mediados pelas mercadorias que produzem, pelas relações monetárias que dão supcrte à troca de seus produtos privados. Assim, a vida em sociedade passa a existir frente aos indivíauos coms algo exterior, material e autônomo, o que passa a ser condição para que possam estabele cer relações como pessoas privadas.

Com a divisão do trabalho dä-se a contradição entre o interesse particular e coletivo de todos os indivíduos que se relacionam entre si. Os agentes sociais envolvi dos na troca buscam unicamente seus pröprios fins nessa transação: cada um não é mais que meio para o outro, para a conse cução de seus pröprios interesses particulares. Embora a reci procidade seja necessäria, os sujeitos da troca são indife rentes entre si;: importam-se, epenas, como meio de satisfação de seus fins privados e egoístas. Nessa contradição entre o interesse individual e coletivo, o coletivo passa a existir não sõ na representação como interesse geral. Tem um respaldo na realidade, visto que se apresenta como a dependência recí proca dos indivíduos entre os quais o trabalno estä dividido. Porēm o coletivo não mais coincide com o interesse individual, sendo o geral uma forma ilusöria de coletividade: coletivida de essa baseada no relacionamento de classes sociais antagôni cas, jả condicionadas pela divisão do trabalho, entre as quais existe uma relação de dominação. Aqueles que têm acesso ao po der político, apresentam seu interesse particular como inte resse geral da sociedade. O interesse coletivo adquire, assim, na qualidade de Estado, uma forma autônoma, separado dos in teresses particulares e gerais. A luta prática desses interes ses particulares que se chocam com o interesse "geral" cria a 
necessidade do controle e intervenção prâtica atravês do Esta do, como ilusório interesse geral. (?)

Com a divisão do trabalho dä-se tambëm a sepa ração entre a atividade intelectual e manual, podendo ser atribuidas a individuos diferentes. E dada a possibilidade da consciência emancipar-se da prätica social existente, chocan do-se com a mesma, porque as relações sociais se contrapõem às forças de produção. (ㅇ) Essa divisão entre trabalho espirị tual e manual se reflete também no seio da classe dominante, em que seus ideólogos ativos se cindem de seus membros ativos. Tal cisão pode assumir matizes de hostilidade a qual se desfaz face a qualquer colisão politica que possa colocar em cheque a própria classe. ( $\underline{9})$

Em sintese, pode-se afirmar que a divisão do trabalho resume as condições sociais nas quais os indivíduos, na qualidade de pessoas autônomas e privadas, produzem valores de troca. (10)

(7) "... a luta prätica desses interesses particulares, que constante mente e de modo real chocam-se com os interesses coletivos e ilusoriamente tidos como coletivos, toma necessärio o controle e a intervenção prä tica através do ilusório interesse geral como Estado". K. Marx e F. En= gels. A Ideologia Alemã, op. cit., p. 49-50.

(8) K. Marx e F. Engels. A Ideologia Alemã, op. cit., p. 45.

(9) "A divisão do trabaiho... exp:essa-se tambem no seio da classe dominante como divisão entre trabalho espiritual e manual, de tal modo que, no interior desta classe una parte aparece como os pensadores desta classe (seus ideólogos ativos, conceptivos, que fazem da formação de ilusões a respeito de si mesma seu principaï meio de subsistência), enquanto que outros relacionam-se com essas idêia e ilusões de maneira mais passiva e receptiva, pois na realidade são os membros ativos dessa classe e têm pouco tempo para produzir idéias e ilusões a respeito de si próprios". K. Marx e F. Engels. A Ideologia Alemā, op. cit., p. 72-73.

(10) Esse carâter privađo da produçãa é um produto his tórico: "Se cada individuo encontra-se isolado e autônomo no seio do processo de produção é devido à divisão do trabalho, que, por sua vez, baseia-se em uma sé rie de condições econômicas que determinam o lugar dos indivíduos no meiō dos restantes e o conjunto de modalidades de sua existência." K. Marx. Los Fundamentos de 1a Crítica, op. cit., p. 560. 
A divisão do trabalho è condição da existência da troca e do valor de troca. A sociedade burguesa è a sociedade do valor de troca desenvolvido, o qual domina toda a pro dução. A relação direta do produtor com o produto de seu tra balho tende a desaparecer, tornando toda a produção dependen te das relações monetärias. O sistema de necessidades se am plia e se torna cada vez mais complexo. A proporção que se de senvolve a divisão do trabalho, mais se produz sob a forma de valores de troca. A troca dos produtos como mercadorias tor na-se o agente mediador dos diversos trabalhos.

'Não è a troca que cria a diferença entre as órbitas da produção. 0 que faz é relacionar essas órbitas distintas entre si, convertendo-as em ramos de uma produção global da sociedade, unidos por laços de dependência:" $\underline{(11)}$

Como a produção e circulação de mercadorias constitui a premissa do regime capitalista de produção é necessärio que a: divisão do trabalho na sociedade tenha adquiri do um certo grau de maturidade para que apareça, como produto tipicamente capitalista, a divisão manufatureira do trabalho. $\underline{(12)}$

A divisão de trabalho na sociedade não se reduz a uma categoria simples e abstrata, mas implica um proces so histórico. Apresenta como condições fundamentais de seu de senvolvimento, entre outras, a separação cidade-campo, certa magnitude e densidade da população, a ampliação do mercado e a consequente diversificação das necessidades sociais, a re gulação das trocas pela lei da concorrência. Assim, também, a emergência da manufatura e da divisão de trabalho que the é

(11) K. Marx. El Capital. Crítica de la Economía Política, op. cit., vol. I, p. 286.

(12) E isto que justifica porque, na reconstrução dessa noção, partiu-se da produção e circulação simples de mercadorias, estabelecendo os fundamentos da divisão social do trabalho, para em seguida abranger as formas específicas que as sume no interior da unidade produtiva no período manufatureiro e na indüstria capitalista. 
peculiar supõe a acumulação e concentração dos instrumentos de produção e de trabalhadores como condição bäsica que prece de a divisão do trabalho na oficina e se desenvolve concomi tantemente à mesma.

O modo de produção correspondente ao capital apresenta dois níveis fundamentais de desenvolvimento: a manu fatura e a grande indústria que especificam formas determinadas de divisão de trabalho, levando à parcialização do próprio trabalho no ato da produção de mercadorias prociutos do capital.

\subsection{A Divisão Manufatureira do Trabalho}

Para que o dinheiro seja trocado enquanto cap tal pelo trabalho livre, supõe, como primeira condição, a associação de trabalhadores por meio do capital, a qual é puramente formal na forma mais simples e independente da divisão do trabalho. Refere-se ao emprego pelo capital de trabalhadores autônomos e dispersos. Tal associação afeta apenas o produto do trabalho e não o pröprio trabalho, sendo as trocas concentradas nas mãos do capital. A segunda condição é a elí minação da autonomia e da dispersão dos trabalhadores, agora agrupados em um só lugar, sob o mesmo mando e sob vigilância. E o capital quem realiza a associação dos trabalhadores na produção, criando o modo de produzir que the é adequado. (13) A partir desse momento, o capital aparece não sỏ como o repre sentante do carăter social da troca, mas, também, do carăter social do trabalho, da força coletiva dos trabalhadores, como a força que cria a unidade. E o próprio capital que vai criar, concomitantemente, a disciplina crescente, a segmentação do

(13) "A produção capitalista tem histórica e logicamente seu ponto de partida na reunião de um nưmero relativamente grande de trabalhadores que trabalham ao mesmo tempo, no mesmo lugar (ou, preferindo-se no mesmo campo de trabalho) na fabricação da mesma classe de mercadorias e sob o mando do mesmo capitalis ta". K. Marx. E1 Capital. Crítica de la Economía Po-. lítica, op. cit., $t$ I, cap. XI, p. 259. 
trabalho, a continuidade e dependência dos processos implica dos na fabricação de um produto no âmago da produção. E criada a manufatura, onde a cooperação baseada na divisão do trabalho adquire a sua forma clässica.

A manufatura implica um processo de produção coletivo, executado por numerosos trabalhadores em cooperação (14) entre os quais se dividem as diversas operações parciais da produção. Essas operações parciais tornam-se função exclusiva de cada trabalhador, convertendo-se em um trabalhador parcial. O produto final passa a ser produto comum de uma coletividade de trabalhadores parciais. O trabalhador perde a capacidade de desenvolver um ofício em toda a sua extensão, à medida que a distribuição do trabalho vai cristalizando-se sob a forma de divisão do trabalho na produção manufatureira.

O trabalho se torna social por excelência, ad quirindo a qualidade de um trabalho social mêdio executado pe los trabalhadores agrupados e os instrumentos de produção ad quirem, concomitantemente, um caräter social. Ao mesmo tenpo, verifica-se a atomização do processo de produção em operações diferenciadas atribuidas a trabalhadores distintos. A fragmen tação desse processo de produção em fases especiais coincide, na manufatura, com a diferenciação do ofício manual nas suas diversas operações integrantes. A execução de tais operações conserva seu caráter manual, dependendo da destreza, segurança e rapidez do trabalhador no manejo de sua ferramenta. A pe rîcia de cada trabalhador parcial ê a base da produção, mas cada um se reduz a executar a mesma operação parcializada con tinuamente, o que leva a produzir mais em menos tempo, redu zindo o emprego improdutivo do trabalho. Acompanha esse pro-

(14) "A forma de muitos trabalhadores, coordenados e reunidos com vis tas a um plano no mesmo processo de produção ou em processos de produção distintos, porêm enlaçados, chama-se cooperação." K. Marx. El Capital. Crítica de la Economia Política, op. cit., cap. XI, p. 252. 
cesso a diferenciação e especialização dos instrumentos de trabalho. A manufatura funciona como um mecanismo de produção cujos örgãos são homens.

A cooperação de muitos trabalhadores exigida pela produção manufatureira permite não apenas potenciar a Eorça de trabalho individual, mas cria uma rorça produtiva no va resultante da jornada de trabalho combinada: a força produ tiva social do trabalho. Essa cooperação, no entanto, não é voluntāria, mas imposta pelo capital. Ela começa no processo de trabalho quando o trabalhador em atividade, já deixou de pertencer a si mesmo sendo, como membro de um organismo traba lhador, uma forma de existência do capital. Por isso, a força produtiva desenvolvida pelo trabalhador é uma força produtiva apropriada pelo capital, que nada the custa, sendo criada à medida que o trabalhador é submetido pelo capital a determi nadas condições de trabalho. Aparece, pois, como força produtiva inerente, inata, ao capita1. (15) Na manufatura, o enri quecimento da força produtiva social do trabalhador coletivo, apropriado pelo capital, é condicionada ao empobrecimento do trabalhador em suas forças produtivas individuais: o conhecimento, a perspicācia, a vontade, as habilidades que o traba lhador axtesanal desenvolviam são agora transferidas ao capital.

(15) "O poder social, isto $\vec{e}$, a força produtiva multiplicada que nas ce da cooperação de muitos indivíduos, exigida pela divisão do trabalho', aperece a estes indivíduos, porque sua cooperação não è voluntäria mas natural, não cono seu pröprio poder unificado, mas como una força estra nha siluada fora deles, cuja origen e destino ignoram, que não podem mais doninar, e, que, „elo conträrio, percorre agora una sërie particular de fases e estágios de desenvolvimento, independente do querer e do agir desses homens, que, na verdade, dirige esse agir e esse querer." K. Marx e F. Engels. A Ideologia Alemä, op. cit., p. 49-50. "A associação dos tra balhadores, a cooperação, a divisá do trabalho, aparecem como força produtiva do capital, do mesmo modo que as forças produtivas que determinam a intensidade e a extensão práticas do trabalho. A força coletiva e o caräter social do trabalho são a força coletiva do capital. O mesmo ocorre com a ciência, con a divisão do trabalho, com a troca que implica a divisäo dessas tarefas. Todas são forças produtivas do capital, o qual aparece conno sujeito das mesmas." K. Marx. Los Fundamentos de la Crítica de la Econonia Politica, op. cit., p. 75. 
"As potências espirituais da produção ampliam-se em es cala e sob um aspecto, à custa de inibir-se nos demais. 0 que os trabalhadores parciais perdem se concentra no capital, enfrentando-os. E o resultado da divisão manufatureira do trabalho que as potências espirituais do processo material de produção se erigem frente aos trabalhadores, como propriedade alheia e poder dominador. Este processo de dissociação começa com a cooperação simples, onde o capitalista representa frente aos traba lhadores individuais a unidade e a vontade do corpo sō cial do trabalho. O processo continua avançando na manū fatura, a qual mutila o trabalhador ao convertê-1o e⿳亠幺 trabalhador parcial. Conclui-se na grande indústria, on de a ciência è separada do trabalho como potência de produção independente e acumulada a serviço do capital." (16)

A manufatura contribui, portanto, para a degra dação do trabalhador individual, acentuando pelo trabalho repetitivo e fragmentado, obstaculizando o disciplinamento da inteligência, a criatividade, criando uma verdadeira "patologia industrial". (17) A divisão manufatureira do trabalho revoluciona o modo: de trabalhar de cada trabalhador individual, fomentando artificialmente uma de suas habilidades parciais e abafando inümeros estímulos e capacidades. Alêm de distribuir os diversos trabalhos parciais entre os individuos, secciona o próprio indivíduo, convertendo-o em um aparato automático adscrito a um trabalho parcial (18). A ciência, a cultura,tor nam-se suscetíveis de coexistirem separadas do trabalho, domi nando-o como força produtiva alheia, em detrimento da intensi ficação da força produtiva do trabalhador individual. Os gastos de formação e treinamento do trabalhador se reduzem e,com isto, o valor de sua força de trabalho.

(16) K. Marx. E1 Capital. Crítica de la Economía Política, op. cit., t. I, cap. XII, p. 294 .

(17) "E indubitâvel que toda divisão de trabalho no seio da sociedade e inseparável de certa degeneração física e espiritual do homem. Porém o período manufatureiro, com seu regime de divisảo peculiar, acentua esse desdobramento social dos ramos do trabalho de tal modo e afeta a tal ponto as raizes vitais do indivíduo, que cria a base e o incentivo para que se forme uma verdadeira patologia industrial..." K. Marx, idem, p. 296.

(18) K. Marx. El Capital. Crïtica de la Economía Politica, op. cit., t. I, cap. XII, p. 298 . 
A manufatura não số subordina os trabalhadores a um mando, mas cria uma hiexarquia entre os prôprios traba Thadores. Estabelece uma divisão entre trabalhadores qualificaços e ñ̃o qualificados, sendo estes ültimos dominantes nume ricamente, mas sob a influência determinante dos primeiros.

A divisão manufatureira do trabalho é um meio de produzir mais mercadorias com a mesma quantidade de trabatho, Eavorecendo maior rapidez ao proces so de acumulação de capital. E um método de criação de mais-valia relativa. (19) $\mathrm{Se}$ de um lado contribui para o desenvolvimento das forças produtivas sociais do trabalho, sendo nesse sentido um progresso histōrico incontestāvel, por outro lado é um meio aprimorado de maior exploração do trabalhador, jă que desenvolve a força produtiva social do trabalho para o capitalista e não para o trabalhador.

A plena realização dessa forma de regime capitalista de produção não se dã sem barreiras: o capital tem que lutar permanentemente contra a insubordinação dos opera rios, de cuja perícia manual depende a produção manufatureira. Ora, a razão determinante do processo de produção é a obtenção da maior valorização possível do capital, ou, em outros termos, a apropriação do trabalho não pago do trabalhador $1 \underline{i}$

(19) K. Marx, nesta passagem, sintetiza o significado da divisão manu fatureira do trabalho: "A divisão manufatureira do trabalho cria a organi zação quantitativa dos processos sociais de produção, isto é, cria wona determinada organização do trabalho social, desenvolvendo com isto, ao mesmo tempo, a nova força social produciva do trabalho. Como forma específicamente capitalista do processo social da produção -- que apoiando-se em bases pre-estabelecidas só podia continuar desenvolvendo-se sob a forma capitalista -- esta organização não è mais que um método para a criação de mais-valia relativa; um procedimento para aumentar, à custa dos traba 1hadores, os Iucros do capital -- a chamada rigueza social,"riqueza das na çöes", etc. Este mëtodo so desenvolve a força produtiva social do traba= tho para o capitatista exclusivamente ao invês de desenvolvê-la para o trabalhador. Alêm disso a converte em força mutiladora do trabalhador individual. Cria novas condições para que o capital domine o trabalho. Portanto, ainda que de um lado represente um progresso histórico e uma etapa necessäria no processo econômico de formação da sociedade, por outro é um meio de exploração civilizada e refinada". K. Marx, idem, p. 297. 
vre pela classe capitalista sob a forma de mais-valia. Assim sendo o enriquecimento do capitalista tem sua outra face: o empobrecimento do trabalhador, agora mutilado como trabalhador parcia1. Essa insubordinação supra-referida tem, portanto, suas razões incrustradas na prôpria forma de organização da produção e da distribuição do trabalho que a caracteriza. Ao crescer o nümero de trabalhadores empregados simultaneamente pelo mesmo capital cresce, também, sua força de resistência e, em contrapartida, a pressão do capital para vencê-la. Contra a luta de resistência do trabalhador, a mutillação de sua vida no trabalho alienado, o capital responde através da imposição da ordem. Essa necessäria função controladora, de vigilância e direção do processo social de trabalho é uma função do capi tal e de seus prepostos. Como a reunião dos trabalhadores na produção é uma iniciativa do capital, cabe-1he, também, garan tir a coordenação e unidade do processo, que aparece na prätí ca como a autoridade do capitalista, como o poder de uma vontade alheia que submete a seus fins as atividades do conjunto dos trabalhadores. Essa função de direção, de vigilância, tra duz-se numa forma despótica, transfigurando-se numa função de exploração, determinada pelo inevitảvel antagonismo das relações sociais que a $\mathbf{i}$ se estabelecem. Estâ voltada, ainda, para a fiscalização do emprego dos meios de produção, evitando sua destruição e seu desgaste. A medida que se expande o capital, a função de vigilância direta dos trabalhadores tende a ser transferida a um grupo de funcionărios que durante o processo de trabalho exerce o mando em nome do capital, restringindose o patrão às funções de alta direção e vigilância.

Concluindo a caracterização da divisão manufatureira do trabalho caberia sintetizar as suas peculiaridades face a divisão do trabalho na sociedade. (20) Essas duas ex-

(20) Ver Marx, K. El Capital. Crítica de la Economía Política, t. I, op. cit., cap. XII. 
pressões da divisão do trabalho articulammse e condicionammse mutuamente, mantendo, no entanto, características específicas. Assim como a.divisão manufatureira do trabalho exige como prëcondição um certo desenvolvimento da divisão do trabalho na sociedade voltada para a produção de mercadorias, a produção manufatureira impulsiona a divisão social do trabalho. Produz uma diferenciação dos ramos da produção ao diversificar os instrumentos de produção e, consequentemente, as indústrias que os produzem. Indústrias que eram exploradas articuladamen te se dissociam, adquirindo autonomia. Certas fases especiais do processo de produção de uma mercadoria tornam-se ramos in dustriais independentes. A produção manufatureira incentiva, ainda, a divisão territorial do trabalho. A manufatura não a fe ta apenas a esfera econômica mas todas as expressões da vida em sociedade, favorecendo a emergência de especialidades e es pecialistas. Ao revolucionar o regime de produção em um ramo industrial afeta necessariamente os demais, visto que, ainda que cada qual produza uma mexcadoria independente, encontramse articulados como fases de um processo global de produção. As transformações operadas na produção agrícola e industrial, a ampliação do mercado mundial, afetam os meios de comunica ção e transporte, os estilos de vida, as atividades científ cas e artísticas.

Porém essas duas expressões da divisão do trabalho -- na sociedade e na manufatura - - apresentam diferen ças essenciais. O que caracteriza a divisão manufatureira do trabalho e o fato de cada trabalhador parcial dedicar-se a uma operação limitada do processo de produção, que considerada em si mesma carece de valor e utilidade. Cada trabalhador parcial não chega a produzir uma mercadoria, dedicando-se apenas a uma operação que ê parte de seu processo de produção. 0 produto final ê um produto comum, fruto da combinação dos trabalhos fragmentados de muitos trabalhadores. O que unifica e articula esses trabalhos parciais é o fato dos trabalhado- 
res venderem suas forças de trabalho a um ünico capitalista, que os enprega como força de trabalho combinada. Jä a divisão de trabaho na sociedade opera pela compra e venda de mercado rias, producos de värios ramos industriais. O que integra os rrabalhos desses diversos ramos é o fato desses produtos serem mercadorias. Enquanto a divisão manufatureira do trabalho supöe a concentração dos meios de produção nas mãos de um ca pitalista, a divisão social do trabalho implica o seu fracionamento entre muitos produtores de mercadorias mutuamente in dependentes. Enquanto na produção manufatureira existem fun ções determinadas para cada conjunto de trabalhadores, na so ciedade a distribuição dos meios de produção e dos produtores nos diferentes ramos sociais do trabalho é regida pela arbi trariedade, pela lei da concorrência. A isto se opõe a divisão manufatureira do trabalho subordinada a um plano e à auto ridade incondicional do capitalista à qual estão sujeitos os trabalhadores como membros de um mecanismo global de propriedade do capitalista.

Essas duas manifestações da divisão do traba1ho convivem sem excluir-se, interinfluenciando-se mutuamente. Porém a divisão manufatureira do trabalho é um produto especí fico da sociedade capitalista, da expansão das forças produti vas e da consolidação do trabalho assalariado. Com ela a divi são social do trabalho ê redimensionada assumindo nova peculiaridade histörica. (21)

(21) Marx, ressaltando a historicidade deste tipo de divisão do traba tho face a outras formas de sociedade afirma: "Na sociedade do regime capitałista de produção a anarquia da divisão social do trabalho e o despotismo da divisão do trabalho na manufatura estão reciprocamente condicionados. Outras formas mais antigas de sociedade em que a especialização da indüstria se desenvolve de modo elementar, para logo cristalizar-se e con solidar-se legalmente, apresentam a imagem de uma organização do trabalhö social sujeita a un plano e a una autoridade, de un lado, enquanto de outro lado excluem radicalmente ou sö estimulam em escala insignificante ou de modo esporádico e fortuito a divisão de trabalho dentro da oficina. K. Marx. El Capital. Crítica de la Economía Política, op. cit., t. I, p. 290. 0 autor estabelece, ainda, como regra geral:"quanto menos a divisão do trabalho no seio da sociedade $\vec{e}$ presidida pela autoridade, mais se desenvol- 


\subsection{A Divisão do Trabalho na Grande Indûstria}

A indüstria manufatureira impulsionada com a expansão do mercado mundial defrontou-se com uma demanda de produtos manufaturados que $j a \overrightarrow{~ n a ̃ o ~ p o d i a ~ s e r ~ s a t i s f e i t a ~ n o ~ e s-~}$ tâgio vigente de ảesenvolvimento das forças produtivas. Sua estreita base têcnica incompatibilizou-se com as demandas da produção que ela pröpria havia criado. Porém um dos resultan tes da manufatura foi a fabricação de instrumentos de traba1ho, introduzindo a indústria de máquinas, cujo desenvolvimen to coloca em questão o princípio da divisão manufatureira do trabalho: sua base manual, a dependência da força muscular e das habilidades do trabalhador especializado no manejo de seus instrumentos de produção. Com o desenvolvimento da manufatura são gestadas, portanto, as bases da grande indüstria que revoluciona o regime de produção, transformando os instru mentos de trabalho em máquinas, nas quais as ferramentas do trabalhador reaparecem combinadas como peças de um aparato me cânico, revestindo uma forma substantiva totalmente emancipada dos entraves e limites prōprios da força humana. 0 instrumento de trabalho adquire independência face ao trabalhador: supera sua debilidade física e sua obstinação. Na grande indûstria capitalista se consuma o divôrcio entre as potências espirituais do processo de produção e o trabalho manual. A perícia do trabalhador individual transforma-se em detalhe se cundário ante a ciência, a tecnologia, as forças naturais e o trabalho social de massa.

A fábrica emerge como a unidade de produção ba seada no maquinismo onde se dã a cooperação simples de inúmeras máquinas funcionando concomitantemente para fins semelhan

ve a divisão do trabalho no interior da oficina e mais se submete tal di visão à autoridade de uma só pessoa. Portanto, em relação â divisão dō trabalho, a autoridade na oficina e na sociedade estâ em razão inversa uma da outra." K. Marx. La Misểria de la Filosofía, op. cit., p. 119-120. 
tes. Reproduz-se aî a cooperação baseada na divisão do trabatho característica da manufatura, porêm, agora, expressa como cooperação de muitas máquinas. O objeto de trabalho percorre diversos processos parciais articulados entre si por uma cadeia de máquinas diferenciadas, relacionadas e complementares.

A manufatura oferece a base elementar da divi são de trabalho e do processo de produção da grande indústria. Logo emerge, no entanto, uma diferença essencial: desaparece o princípio subjetivo da divisão do trabalho, isto é, a neces sidade de adaptação do processo de produção ao trabalhador par cial que executava cada etapa do mesmo com sua ferramenta, dependendo de suas capacidades e habilidades pessoais. $\mathrm{Na}$ grande indústria automatizada o trabalhador defronta-se com um organismo objetivo da produção como condição dada. (22) A mãquina de trabalho combinada ê um sistema de diversas máquinas e grupos de mäquinas tanto mais perfeita quanto menor a interrupção do trânsito da matêria do início da produção atê - seu término. Tal característica a diferencia da produção ma nufatureira em que o princípio da produção é dado pelo isolamento e segmentação das diversas operações contidas na fabricação de um produto. No modo de produzir peculiar a este está gio avançado da produção capitalista o papel do trabalhador modifica-se substancialmente: a eficácia no manejo dos instru mentos de trabalho passa do trabalhador para a máquina na

(22) "Na manufatura a divisão e a articulação do processo social de trabaIho ê puramente subjetiva, uma siriples combinação de trabalhadores parciais. No sistema baseado no maquinisno, a grande indüstria possui um organismo perfeitamente objetivo com o qual o trabalhador encontra-se co mo condição material de produção pronta e acabada. Na cooperação simples̄ e, inclusive, na cooperação especificada pela divisão do trabalho a substituição do trabalhador isolado pelo trabalhador coletivo apresenta-se como algo puramente casual. As máquinas combinadas, fora algumas exceções, só funcionam nas mãos do trabalhador diretamente socializado ou coletivo. Portanto, agora, é a propria natureza do instrumento de trabalho que im põe como necessidade técnica o caräter cooperativo do processo de trabāa tho". K. Marx. El Capital. Crítica de la Economía Política, op. cit., t. I, cap. XII, p. 315-316. 
qual é incorporada. Torna-se o trabalhador um mero vigilante da máquina intervindo, esporadicamente, num sistema automatiza do. Supera-se, pois, a base têcnica da grande indüstria. Os trabalhadores se transformam em simples örgãos de um maquinis mo subordinado a uma força motriz central. Enquanto na manufa tura o movimento parte do trabalhador que se serve de suas ferramentas, na fábrica ele serve à máquina que se torna o su jeito da produção. Os homens passam a seguir os movimentos da mâa quina que se sobrepõem a eles como um mecanismo morto ao qual são incorporados como apêndices vivos, acessórios conscientes. A máquina não livra o trabalhador do trabalho, mas priva-o de seu conteúdo. Este trabalho mecanizado e automatizado de mera vigilância esgota ainda mais o trabalhador: afeta-1he o siste ma nervoso, depaupera sua atividade muscular, confisca-lhe to da atividade física e intelectual. Na manufatura o trabalhador imprimia vida aos instrumentos de trabalho graças à sua habilidade. A mäquina concentra em si a habilidade, força e destreza do trabalho socialmente acumuladas, substituindo o trabalhador graças à aplicação de conhecimentos científicos na sua construção. A ciência se manifesta nas máquinas e aparece como alheia e exterior aos trabalhadores. Jã não existe no cérebro dos trabalhadores mas, apropriada pelo capital e objetivada no maquinismo, atuando sobre eles como uma força estranha, força da própria mäquina. (23)

(23) "A ciência não custa absolutamente "nada" ao capitalista, mas is to nầ o impede que a explore. O capital se apropria da ciência alheia, as sim como se apropria do trabalho dos demais. Porêm a "apropriação" capi talista" e a "apropriação pessoal" são coisas radicalmente distintas, seja tratando-se da ciência ou da riqueza material". K. Marx. El Capital. Critica de la Economia Política, op. cit., t. I, p. 316 (Nota de rodape). 
Embora a apropriação do trabalho vivo pelo tra balho morto seja inerente a natureza do capital, ela adquire expressão patente na grande indüstria. 0 trabalho objetivado aparece fisicamente como a força dominante face o trabalho vivo: não só o apropria, mas o domina ativamente no próprio processo de produção. O domínio do homem pela coisa, pelo fruto de seu propprio trabalho materializado, apropriado por outro, adquire aí uma manifestação explícita. 0 trabalho vivo deixa de ser a unidade dominante do processo de produção: $\vec{e}$ reduzido quantitativamente a proporções ínfimas em relação ao trabalho materializado, embora qualitativamente conserve uma importância fundamental na criação do valor. Assume um papel subalterno face à atividade científica geral, à tecnologia aplicada na produção e à força produtiva derivada do conjunto da organização social da produção, que não são mais que outras dâdivas naturais do trabalho social, embora sejam produtos históricos. A ciência -- essa força produtiva geral -desempenha um papel bâsico no desenvolvimento da indústria automatizada. O capital apropria-se gratuitamente desse progresso geral do trabalho social, cujos resultados fixam-se no capital e não no trabalho, sendo utilizados em função de seus próprios fins de valorização e dominação.

0 capital implica, por definição, na potencia ção da força produtiva do trabalho que se apresenta como força produtiva exterior ao trabalho e instrumento de debilita ção do trabalhador. E, no entanto, na qualidade de capital fi xo que o maquinismo torna o trabalhador dependente, objeto de apropriação e dominação. E só adquire essa forma de capital fixo porque tem como contrapartida o trabalho assalariado. Tal distinção $\vec{e}$ fundamental porque importa distinguir a ten dência universal e civilizadora do capital -- o desenvolvimen to universal das forças produtivas, das quais a ciência não é mais que um aspecto -- do carâter alienante e destrutivo que assumem nessa forma de produção. Essa tendência do desen- 
volvimento das forças produtivas encontra-se em contradição com a forma limitada que o impulsiona. A limitação do capital está em que todo o seu desenvolvimento efetua-se de maneira antagônica: o desenvolvimento da riqueza social, das condições de trabalho, da ciência, etc., aparecem como alienadas do trabalhador que se comporta frente a tais condições por ele produzidas como riqueza alheia, causadora de sua pobreza. o processo de objetivação do poder material do trabalho é um produto do pröprio trabalhador e a ele corresponde. Porém o fato dessas condições objetivas se tornarem cada vez mais independentes do trabalhador enfrentando-o como força alheia, não corresponde ao trabalhador, mas às condições de produção personificadas, isto é, ao capital. Esse processo possuirá o caráter de alienação para o trabalhador ou de apropriação do trabalho de outro pelo capital durante o período em que, a ní vel do capital e do trabalho, esse corpo objetivo da atividade funcione em oposição ao trabalho imediato. Tal inversão -o domínio do homem pelas coisas -- a essa subversão -- o fato do trabalhador criar, contraditoriamente, as próprias condições de sua dominação -- são reais, não existindo apenas no espírito do capital e do trabalho. Correspondem a uma necessidade histórica: é a condição necessária ao desenvolvimento das forças produtivas a partir dessa base determinada. Porēm não se trata de uma necessidade absoluta, mas efêmera, 0 resul tado desse processo está voltado para a destruição dessa base e dessa forma de desenvolvimento, apontando para o desenvolvimento das forças produtivas sem obstäculos e para a possibí lidade do desenvolvimento universal do indivíduo -- de sua individualidade social -- numa sociedade de nova natureza. A distinção supra ressaltada é importante porque para os economistas burgueses a necessidade de objetivação das forças sociais do trabalho aparece indissoluvelmente ligada à necessidade de sua alienação face ao trabalhador. (24) Mas, partindo

(24) Ver K. Marx. Los Fundamentos de la Crîtica de la Economía Polí tica, op. cit., t. II, p. 344 . 
do trabalho assalariado, as máquinas sô podem surgir em oposi ção ao trabalho vivo. Como propriedade e força do capital de vem opor-se necessariamente ao trabalhador. Esse modo de distribuição é uma condição do modo de produção baseado no traba tho assalariado. Entretanto, isso não significa que as máquinas deixariam de atuar como agentes de produção ao serem apro priadas pelos trabalhadores associados. Implicaria em outro tipo de distribuição, sobre nova base produtiva: outro modo de reprodução da vida e da produção que só pode ser criado no próprio processo histörico social.

Em síntese, o capital tende a ampliar as forças produtivas e a reduzir ao máximo o tempo de trabalho socialmente necessário à reprodução do trabalhador e de sua famîlia, expandindo assim o sobretrabalho gratuitamente apropria do. Esta tendência se realiza na grande indústria com a trans formação dos instrumentos de trabalho em máquinas articuladas. E este o sentido fundamental dessa revolução operada no modo de produzir. A finalidade do emprego das máquinas não é facilitar os esforços do homem, mas reduzir o trabalho necessário e, em contrapartida, ampliar a parcela da jornada de trabalho entregue sem equivalente ao capitalista. E um meio peculiar de produção de mais-valia relativa, de exploração de trabalho de modo cada vez mais intensivo. E esta a razão histórica que impulsiona a grande indüstria e a divisão do trabalho que a caracteriza. Trata-se de transformação histōrica dos instru mentos de trabalho tradicionais e da atividade humana no seu manejo em meios adequados à forma capitalista de exploração. $\underline{(25)}$

(25) "Para o capital o desenvolvimento dosmeios de trabalho em maqui nismo ná é fortuito; é a transformação histôrica dos meios de trabalhō tradicionais em meios adequados à forma capitalista. A acumulação do saber, da habilidade assim como todas as forças produtivas da inteligência social ficam, então absorvidas pelo capital, opondo-se ao trabalho. Daí em diante aparecem como uma propriedade do capital ou, mais exatamente, do capital fixo, à medida em que ingressa no processo de trabalho como um meio de produção efetivo. K. Marx. Los Fundamentos de la Crî́tica de la Economia Politica, t. II, op. cit., p. 795 . 
O grau de desenvolvimento da divisão do trabaTho vigente na indüstria capitalista expressa o grau de desen volvimento das forças produtivas e a organização e distribuição do trabalho que the é peculiar. Como a grande indüstria apresenta como ponto de partida a transformação dos instrumen tos de trabalho em mâquinas, privilegiamos a discussão desse aspecto como condição para explicitar as peculiaridades do pa pel do trabalhador nesse estágio de desenvolvimento das rela ções capitalistas de produção e sua submissão ao tipo peculiar de divisão do trabalho.

o crescimento da população trabalhadora é uma das condições da introdução das máquinas para substituir o trabalho. Elas não surgem como alternativa à falta de mão-deobra, mas para restringir o uso da força de trabalho à propor ções adequadas às necessidades de reprodução do capital. Isto porque a produção capitalista apresenta como condição necessă ria um maior conjunto absoluto de trabalho necessārio a uma maior massa possível de sobretxabalho em relação ao trabalho pago. Sua condição essencial é, pois, um crescimento máximo da população, devendo a força de trabalho ser massiva para que as mäquinas se desenvolvam. Para que o capitalista possa se apropriar do sobretrabalho da população ativa é necessärio que haja uma superpopulação inativa em oposição à população necessāria a esse estágio histôrico da produção. Explicita-se ai o papel do exército industrial de reserva. Com a expansão das forças produtivas sociais do trabalho o tempo de traba 1ho socialmente necessário é reduzido, ampliando-se o trabalho excedente, conforme o já explicitado. Consequentemente par te da mão-de-obra passa a ser supërflua, porque com o trabalho potenciado a parcela da classe trabalhadora em atividade torna-se suficiente para efetuar a massa de sobretrabalho anteriormente produzida por toda a mão-de-obra empregada. Assim, a diminuição do trabalho necessário com as transformações ope radas no regime de produção industrial significa a criação de 
uma superpopulação crescente, desprovida de todos os recursos e, ainda, dos mejos de procuran trabalho. Não podendo sobrevi ver de seu trabalho enquanto esta impossibilitada de realizä1o, sua existência passa a depender da renda de todas as clas ses. A sociedade é obrigada a assumir a manutenção dessa parcela da classe trabalhadora, momentaneamente excluída do me $\underline{r}$ cado de trabalho, no sentido de manter viva, em reserva, essa força de trabalho potencial para utilização posterior nos períodos de expansão da produção.

$\mathrm{Na}$ sociedade capitalista a redução do trabalho necessário obtido com o desenvolvimento das forças produtivas materiais não tem como contrapartida a ampliação do tempo livre do trabalhador; estâ voltada para ampliar ao máximo o tem po de trabalho não pago, fazendo com que o trabalhador consagre ao capitalista todo o seu tempo de trabalho e sua vitalidade aí consumida. Mas não se pode desconhecer a importância histórica de tảl redução. Uma vez liberado das travas do trabalho alienado, o trabalhador emancipado poderâ usufruir dos benefícios da redução do tempo de trabalho fazendo livre uso desse tempo disponível para o livre desenvolvimento de suas individualidades sociais. Não se trata de livrá-lo do traba1ho, mas do processo de valorização que torna o trabalho um meio de dominação do próprio homem. O desenvolvimento das for ças produtivas é uma das condições da emancipação do traba1ho.

Com a produção industrial, a divisão do traba tho na fäbrica tende a perder o caräter de especialidade; (26) as operações que exigem grande habilidade do trabalhador

(26) "O que caracteriza a divisão do trabalho no seio da sociedade $\hat{e}$ que engendra especialidades, as discintas profissões, o idiotismo do ofício. 0 que caracteriza a divisão do trabalho na oficina mecânica é que o trabalho dentro dela perde todo o carâter de especialidade. Porém enquanto cessa todo o desenvolvimento especial começa a ser possível sentir todo o afã da universalidade, a tendência a un desenvolvimento integral do indivỉduo. A oficina mecâmica suprime as profissões isoladas e o idiotismo do ofício. K. Marx. La Miséria de la Filosofia, op. cit., p. 127. 
tendem a ser substituídas por equipamentos especiais que con centram em $\mathrm{si}$ tais exigências, tornando necessârio apenas o trabalho de vigilância de trabalhadores não qualificados. Como a habilidade no manejo dos instrumentos de trabalho ê deslocada do trabalhador para a máquina e como o movimento glo bal da fábrica não parte do trabalhador, mas do rítmo impresso pela máquina, jā não existe necessidade tëcnica de consoli dar a divisão do trabalho manufatureiramente, mediante a con tínua adaptação do trabalhador a mesma função. A rapidez no aprendizado de operações mecanizadas reduz as exigências de formação especial dos trabalhadores manuais e o preço da mãode-obra. O parcelamento e a simplificação das atividades da produção é tal, que o trabalhador que se sujeita ao trabalho fabril durante anos, não aprende nenhum trabalho capaz de pro duzir um efeito ütil. O trabalho perde o seu valor de uso e, com isso o seu valor de troca. O trabalhador na indüstria pode movimentar-se de uma máquina a outra, sem que interrompa o processo de trabalho, conforme a vontade de quem dirige o seu trabalho. Assim a hierarquia dos trabalhadores especializados da manufatura tende a ser substituída pela equiparação dos diversos trabalhos manuais. O capital é nivelador por excelência: estabelece a nivelaçăo dos diversos trabalhos e a igualdade de condições da exploração do trabalho. (27) Mas, ainda que tecnicamente a grande indústria venha abolir a divi são do trabalho que supõe a anexar a vida de um homem a uma operação detalhista, a forma capitalista da produção industrial tende a consolidá-la e a reproduzi-la como um meio ainda

(27) Na grande indüstria o gxupo especializado de trabalhadores da manufatura é substituído pelo trabalhador principal com alguns auxiliares. A distinção que passa a ser estabelecida é entre os trabalhadores me cânicos que operam efetivamente as mäquinas, os simples peões que ajudam esses trabalhadores, fornecendo materiais às mäquinas e una categoria de trabalhadores de nível superior, encarregado do controle e reparação das mâquinas: engenheiros, mecânicos, etc. Tal divisão de trabalho é aí basicamente técnica. Ver: El Capital. Crítica de la Economîa Polîtica. t. I, cap. XIII, p. 347. 
mais violento de exploração da força de trabalho: transformase na especialidade de servir a uma máquina parcial durante toda uma vida.

O sistema automatizado substitui a mão-de-obra pela mäquina, a divisão de trabalho entre os diversos operá rios pela decomposição do processo de produção em suas partes integrantes, executadas por mảquinas vigiadas e abastecidas pelos trabalhadores. A cooperação e a divisão do trabalho rea. parecem agora com o caräter de distribuição dos diversos trabalhadores entre as mäquinas especializadas e os diferentes departamentos da fábrica. Tal organização da produção, ao reduzir o uso da força muscular permite a ampliação do contin gente disponivel dos assalariados mediante a incorporação do trabalho da mulher e da criança, colocando toda a família tra balhadora sob a dependência do capital. Nesse processo,deprecia a força de trabalho ao lançar no mercado todos os membros da familia trabalhadora, distribuindo entre eles o valor do trabalho do seu chefe. Amplia, também, o grau de exploração da família trabalhadora, expresso não sô na ampliação da jornada de trabalho, mas na potenciação do trabalho face às barreiras impostas pela sociedade ao prolongamento desmedido da quela. A medida que a jornada de trabalho é reduzida legalmen te, como conquista da luta de resistência da classe trabalhadora, o capital cria meios para ampliar a intensidade do trabalho exigindo do trabalhador um maior desgaste durante o mes mo período de tempo, seja aumentando a velocidade do trabalho, seja aperfeiçoando os meios de produção. A condensação do tra balho num dado lapso de tempo é um meio de obter maior quantí dade de trabalho à custa de maior desgaste humano. Por outro lado, a economia dos meios de produção se converte, nas mãos do capital, em agressão sistemātica às condições de trabalho e, portanto, à vida do trabalhador: significa roubo de espa ço, luz, ar, meios pessoais de proteção face a insalubridade e perigos do ambiente de trabalho, etc. Ao reduzir o tempo de 
dicado ao trabalho doméstico peì incorporação da mulher e das crianças à produção aumenta os gastos monetärios da famí 1ia, deduzidos dos rendimentos obtidos no trabalho. A falta de tempo para os cuidados familiares contribui para ampliar a mortalidade infantil, a crininalidade, a degeneração física e intelectual da familia trabalhadora. Ao mesmo tempo a grande indūstria, ao designar a mulher, ao jovem e às crianças um pa pel decisivo na organização social da produção, retirando-os da örbita doméstica, estabelece novas bases para a organização da família e das relações entre os sexos.

A rígida disciplina imposta pelo trabalho meca nizado exige que os trabalhadores modifiquem seus hábitos de vida, de modo a se adaptarem ao rítmo regular e invariável do trabalho. Na fäbrica é imposta uma disciplina quartelar, res paldada por uma Iegislação que expressa a regulamentação social do processo de trabalho, sendo, inclusive, suas transgressões traduzidas em deduções salariais ou em motivos de demissöes. (28) Porém o controle do operärio extrapola o âmb to fabril, sendo complementado por instituições sociais que, em nome do capital, contribuem para o estabelecimento de meios de tutela e normatização de vida do trabalhador, socializando-o de modo a adaptá-1o à disciplina e aos métodos de trabalho requeridos pela organização industrial. (29)

Finalizando essa parte, importa ressaltar que a nova forma de divisão do trabalho na grande indüstria não pode ser pensada segmentadamente, como se afetasse apenas o processo de trabalho no interior da fábrica. 0 desenvolvimen to industrial modifica a pröpria organização da vida na socie dade: universaliza a concorrência, cria e consolida o mercado

(28) "O açoite do capataz de escravos dá lugar ao regulamento penal do vigilante". K. Marx. E1 Capital. Crítica de la Economia Política, op. cit., t. I, p. 351 .

(29) Ver A. Gramsci. "Americanismo e Fordismo". In: Obras Escolhidas. vol. II, Lisboa, Ed. Estampa, 1974. 
mundial, desenvolve os meios de comunicação, a propaganda, submete a si o comércio, multiplica e diversifica os ramos in dustriais, amplia a concentração e centralização do capital. Consolida, ainda, a divisão do trabalho entre cidade e campo, faz crescer as cidades, transfoxma a agricultura e as relações de produção aî vigentes. Amplia o mercado de mão-de-obra, estabelecendo mobilidade sem limites da força de trabalho e solidifica a segmentação entre trabalho manual e intelectual. A indústria moderna revoluciona constantemente as tëcnicas de produção e, com elas as funções do trabalhador e as combinações sociais do processo de trabalho. Com isto, revoluciona constantemente a divisão do trabalho dentro da sociedade, lan çando massas de trabalhadores e de capitais de um ramo a outro da produção.

Enfim, a divisão capitalista do trabalho cria novas necessidades sociais, transforma as relações sociais, a moral, os costumes, a religião, a organização familiar, o lazer, etc. Afeta todo o modo de vida e de trabalho da sociedade.

E dentro dessas condições que se pretende situar a emergência e expansão da profissão de Serviço Social na sociedade capitalista. 
4. O SERVIÇO SOCIAL NO PROCESSO' DE REPRODUÇAO DAS RELAÇOES SOCIAIS

\subsection{Perspectiva de Análise.}

A presente análise estä voltada para a recons trução do objeto de estudo -- a profissão de Serviço Social-segundo a orientação teórico-metodológica anteriormente expres sa. Trata-se de um esforço de captar o significado social des sa profissão na sociedade capitalista, situando-a como um dos elementos que participa da reprodução das relações de classes e do relacionamento contraditório entre elas. Nesse sentido, efetua-se um esforço de compreender a profissão historicamente situada, configurada como um tipo de especialização do tra balho coletivo dentro da divisão social do trabalho peculiar à sociedade industrial.

Poder-se-ia afirmar que as reflexões aqui reu nidas têm èm vista responder à seguinte indagação: como o ser viço Social se situa na reprodução das relações sociais? Assim, mais do que uma anâlise centrada nos elementos constitutivos que dão um perfil peculiar ao Serviço Social, face a ou tras profissões, o esforço orienta-se no sentido de apreender as implicações sociais que conformam as condições desse exercício profissional na sociedade atual. 
Ainda a nível introdutório, vale ressaltar que, a pretensão aqui se restringe ao estabelecimento de hipō teses diretrizes de trabalho, () norteadoras da análise, que permitam caracterizar a participação do Serviço Social no pro cesso de reprodução das relações sociais, na perspectiva do capital e do trabalho.

Dentro da referência analítica adotada, cabe reafirmar que a reprodução das relações sociais não se restringe à reprodução da força viva de trabalho e dos meios objetivos de produção (instrumentos de produção e matérias-prị mas). A noção de reprodução engloba-os; enquanto elementos substanciais do processo de trabalho, mas, também, os ultrapassa. Não se trata, apenas, da reprodução material no seu sentido amplo, englobando produção, consumo, distribuição e troca de mercadorias. Refere-se à reprodução das forças produ tivas e das relações de produção na sua globalidade, envolven do, também, a reprodução da produção espiritual, isto é, das formas de consciência social: jurídicas, religiosas, artísticas ou filosóficas, através das quais se toma consciência das mudanças ocorridas nas condições materiais de produção. Nesse processo são gestadas e recriadas as lutas sociais entre os agentes sociais envolvidos na produção, que expressam a luta pelo poder, pela hegemonia das diferentes classes sociais sobre o conjunto da sociedade.

(1) As hipöteses diretrizes constituem "a base estratégica para a in vestigação do fenômeno..."; não são concebidas "como hipóteses para verî ficaçao, inferidas empiricamente por meio de pesquisa anterior; mas hipô teses de trabalho baseadas nos quadros reais da pesquisa e formuladas com o fim de orientar teoricamente a pesquisa". F. Fernandez. "Raça e sociedade: O preconceito social em São Paulo" (Projeto de Estudo). In: A sociologia numa era de revolução social. Rio de Janeiro, Zahar, 1976. 2a. ed., cap. IX, p. 296 e 300.

(2) Ver, por exemplo, o texto clássico de Marx, que expōe a noção de sociedade enquanto totalidade e o desenvolvimento desigual de seus elementos: K. Marx. "Prefácio à contribuição à crítica da Economia Política. In: K. Marx e F. Engels, Textos 3, op. cit., p. 60.93. 
Assim, a reprodução das relações sociais é a reprodução da totalidade do processo social, a reprodução de determinado modo de vida (3) que envolve o cotidiano da vida em sociedade: o modo de viver e de trabalhar, de forma social mente determinada, dos indivíduos em sociedade. Envolve a reprodução do modo de produção, entendido na linha de interpretação que Lefebvre (4) faz da noção:

"Quanto ao modo de produção (capitalista) este concei to designa em Marx o resultado global das relações de antagonismo: "salärio/Capital", "proletariado / burguesia". Estas relaçōes sociais não entram na prätica da sociedade, e da sociedade burguesa, a não ser através de formas que as sustêm e as mascaram; por exemplo, a forma contratual (a do "contrato de trabalho", ficticiamente livre, que liga os membros da classe traba lhadora e os da burguesia, e que pretensamente os associa). Este resultado global comprende, portanto, as elaborações jurídicas das relações de produção, as re lações de propriedade codificadas -- as ideologias que "exprimem" também, dissimulando-as, as relações de an tagonismo --, as instituições políticas e "culturais", a ciência etc." (5)

Trata-se, portanto, de uma totalidade concreta em movimento, em processo de estruturação permanente. Entendida dessa maneira, Ia reprodução das relações sociais atin ge a totalidade da vida cotidiana, expressando-se tanto no trabalho, na família, no lazer, na esçola, no poder, etc., co mo também na probissão. I

(3) Ver K. Marx. A Ideologia..., op. cit., p. 27

(4) H. Lefebvre. "Estrutura socia 1: A Reprodução das relações sociais." In: M.M. Foracchi e J. S. Martins. Sociologia e sociedade. Leitu ras de iñtrodução à Sociologia. Rio de Janeîro, Liviros Tecrícos e Cientí ficos, 1977. p. 220 .

(5) E evidente, portanto, que tal concepção não se confunde com a interpretação sistêmica do modo de produção de cumho estrutural funciona lista. Não diz respeito a un todo fechado, em que as partes mantêm relativa autonomia, expressa em "instâncias" econômicas, políticas e ideolögicas e em niveis de determinaçōes e sobredeteminaçōes. 
Isso supõe, como diretriz de trabalho, considerar a profissão sob dois ângulos, não dissociáveis entre si, como duas expressões do mesmo fenômeno: como realidade vivida e representada na e pela consciência de seus agentes profissionais expressa pelo discurso teörico-ideológico sobre o exercício profissional; a atuação profissional como atividade socialmente determinada pelas circunstâncias sociais objetivas que conferem uma direção social à prática profissional, o que condiciona e mesmo ultrapassa a vontade e/ou consciência de seús agentes individuais.

A unidade entre essas duas "dimensões" é contraditória, podendo haver uma defasagem entre as condições e efeitos sociais objetivos da profissão e as representações que legitimam esse fazer. Em outros termos: uma defasagem entre intenções expressas no discurso que ratifica esse fazer e o prōprio exercício desse fazer. o esforço estā direcionado, pois, para apreender o Serviço Social inserido no processo so cial. (ㅁ)

A reflexão teórica sobre o Serviço Social no movimento de reprodução da sociedade não se identifica com a defesa da tese unilateral que tende a acentuar, aprioristicamente, o caräter "conservador" da profissão como esforço e apoio ao poder vigente. Não significa, ainda, assumir a tese oposta, amplamente divulgada na literatura profissional lati. no-americana recente que sustenta, a nível de pïincípio, a di mensão necessariamente "transformadora ou revolucionāria" da atividade profissional. Ambas as posições acentuam, apenas e de modo exclusivo, um pólo do movimento contraditório do con-

(6) "Por processo social não entendemos o sentido intersubjetivo das relaçoes sociais, mas sim que as relações sociais são mediatizadas por condições históricas e que os processos têm duas dimensões: a da consciência subjetiva da situação e a do sentido e direção objetiva que assume. Então entre estes sujeitos hâ una realidade objetiva e construída, cujos significados podem ser conpreendidos de diferentes modos." J.S.Mar tins. Capitalismo e tradicionalismo. Es tudos sobre as contradições da sociedađde agrāria no Brasil. São Paulo, Pioneira, 1975. p. 54. 
creto, sendo nesse sentido unilaterais. Não se esgota a anâli se da profissão na afirmativa mecanicista que, sustentando ser o Serviço Social um dos instrumentos a serviço de um poder mo nolítico, conclui estar a profissão necessariamente fadada a constituir-se num esforço exclusivo do mesmo. Por outro lado, o voluntarismo que impregna a posição oposta, ao considerar o Assistente Social como "O agente de transformação", não reconhece, nem elucida, o verdadeiro caráter dessa prática na sociedade atual. Ao superestimar a eficácia política da ativida de profissional, subestima o lugar das organizações políticas das classes sociais no processo de transformação da sociedade, enquanto sujeitos da história; por outro lado, parece desconhecer a demanda do mercado de trabalho.

Tais consideraçōes não visam sustentar uma po sição intermediâria ou concjliatória de tendências opostas, mas estão inscritas na preocupação de recuperar, na análise dessa expressão da prātica social, o carāter da diversidade do movimento histórico.

O movimento de reprodução do capital, que re cria o môvel bâsico da continuidade da organização dessa sociedade - - a criação e apropriação do trabalho excedente, sob a forma de mais-valia - recria, tambẻm, em escala ampliada, os antagonismos de interesses objetivos inerentes às relações sociais, atravês das quais se efetiva a produção. Concomitantemente, no mesmo processo, reproduz-se a contradição entre a igualdade jurídica de cidadãos "livres" e a desigualdade econômica que envolve a produção cada vez mais social contraposta à apropriação privada do trabalho alheio. Em outros termos: são reproduzidas as condiçōes de exploração ou da repro dução da riqueza pelo trabalhador como riqueza alheia; as relações sociais que sustentam o trabalho alienado com seus antagonismos e o mascaramento ideológico que encobre e revela sua verdadeira natureza. 
Ora, o Serviço Social, como instituição compo nente da organização da sociedade, não pode fugir a essa realidade. As condições que peculiarizam o exercício profissional são uma concretização da dinâmica das relações sociais vigentes na sociedade, em determinadas conjunturas históricas. Como as classes sociais fundamentais e suas personagens só existem em relação, pela mütua mediaçāo entre elas, a atua ção do Assistente Social é necessariamente polarizada pelos interesses de tais classes, tendendo a ser cooptada por aqueJes que têm uma posição dominante. Reproduz também, pela mesma atividade, interesses contrapostos que convivem em tensão. Responde tanto a demandas do capital como do trabalho e so po de fortalecer um ou outro pölo pela mediação de seu oposto. Participa tanto dos mecanismos de dominação e exploração como, ao mesmo tempo e pela mesma atividade, da resposta às necessi dades de sobrevivência da classe trabalhadora e da reproduçã do antagonismo desses interesses sociais, reforçando as contradiçōes que constituem o móvel basico da histöria. A partir dessa compreensão é que se pode estabelecer uma estratégia profissional e politica, para fortalecer as metas do capital ou do trabalho, mas não se pode excluí-las do contexto da prâa tica profissional, visto que as classes só existem inter-rela cionadas. E isto, inclusive, que viabiliza a possibilidade de o profissional colocar-se no horizonte dos interesses das clas ses trabalhadoras.

E este o ponto de partida da anälise, a qual deverá demonstrar, no seu desenvolvimento teörico e empírico, o que tem sido a força dominante na trajetória da prática his tórica do Serviço Social: atender, prioritariamente, uma demanda do capital ou do trabalho, tendo por suposto que estas forças contraditórias não se excluem do contexto profissional.

A perspectiva analítica estä voltada, pois, para efetuar a reconstrução da profissão na ótica das relações de classes, em que as personagens sociais envolvidas na. 
prätica profissional, face às quais o Assistente Social exerce uma função mediadora, são encaradas mais alêm de meras individualidades. As personagens sociais que entram na relação profissional são consideradas, simultaneamente, enquanto seres sociais e particulares, e em cujo modo de ser, de atuar e de ver o mundo estão contidas as determinações sociais deriva das da posição que ocupam no processo de produção e no jogo do poder. Não se nega a singularidade dos indivíduos, numa ví são determinista da história, mas essa individualidade $\vec{e}$ tida como expressão e manifestação de seu ser social, de sua vida em sociedade. Ressaltamos isto, porque a particularização do indivíduo e de seu trabalho tende a ser representada na per $\underline{s}$ pectiva de sua individualidade. E concebida como se sua parti cularidade intelectual e moral houvesse adquirido uma particu laridade social e não o inverso: sua individualidade como manifestação da vida em sociedade. Tal concepção, que emana da circulação simples de mercadorias, confirma a liberdade dos indivíduos necessāria à troca de mercadorias e permanece viva em toda a economia burguesa, tendo adquirido uma força muito expressiva na representação ideológica do Serviço Social. Essa forma de ver está presente em certo tipo de literatura pro fissional, que tende a encarar o indivíduo focalisticamente, segmentado da sociedade. E a visão a-histörica do indivíduo abstraído, artificialmente, da produção material, das rela ções de classe, enfim, da sociedade.

$\mathrm{Na}$ perspectiva ora adotada, os "contratantes" do profissional -- os capitalistas e seus representantes no aparelho de Estado - - e os "clientes" ou usuários dos servi ços prestados pelo Assistente Social -- os trabalhadores assa lariados a quem se dirigem, prioritariamente, tais serviços 
-- são apreendidos enquanto representantes de interesses de classes, personificando caregorias econômicas. (ㄱ)

\subsection{A Intervenção do Agente Profissional nas Relações. Sociais.}

Dentro da orientação analítica expressa neste ensaio, parte-se do pressuposto de que a compreensão da profissão de Serviço Social implica o esforço de inseri-la no conjunto de condições e relações sociais que the atribuem um significado e nas quais torna-se possível e necessária. Afír ma-se como um tipo de especialização do trabalho coletivo, ao ser expressão de necessidades sociais derivadas da prática histörica das classes sociais no ato de produzir e reproduzir os meios de vida e de trabalho de forma socialmente determina da. O desenvolvimento das forças produtivas e as relações so ciais engendradas nesse processo determinam novas necessidades sociais e novos impasses que passam a exigir profissionais especialmente qualificados para o seu atendimento, segun do os parâmetros de "racionalidade" e "eficiência" inerentes à sociedade capitalista.

- Serviço Social se gesta e se desenvolve co mo profissão reconhecida na divisão social do trabalho, tendo por pano de fundo o desenvolvimento capitalista industrial $e$ a expansão urbana, processos esses aqui apreendidos sob o ângulo das novas classes sociais emergentes -- a constituição e expansão do proletariado e da burguesia industrial -- e das modificações verificadas na composição dos grupos e frações de classes que compartilham o poder de Estado em conjunturas históricas específicas. E nesse contexto, em que se afirma a

(7) Esta precisão ē matndnincicamente importante: "aqui nos referimos âs paccone ammunto personificação de categorias econômicas, reprecentantes de determinados interesses e relações de classe". K.Marx. El Capital. Crítica de la Economía Política, op. cit., Prôlogo da la. ed., t. I, p. XV. 
hegemonia do capital industrial e financeiro, que emerge sob novas formas a chamada "questão social", a qual se torna a ba se de justificação desse tipo de profissional especializado. A questão social não $\bar{e}$ senão as expressões do processo de for mação e desenvolvimento da classe operäria e de seu ingresso no cenärio politico da sociedade, exigindo seu reconhecimento como classe por parte do empresariado e do Estado. E a manifestação, no cotidiano da vida social, da contradição entre - proletariado e a burguesia, a qual passa a exigir outros ti pos de intervenção, mais além da caridade e repressão. O Esta do passa a intervir diretamente nas relações entre o empresariado e a classe trabalhadora, estabelecendo não só uma regulamentação jurídica do mercado de trabalho, através de legislação social e trabalhista específicas, mas gerindo a organizarão e prestação dos serviços sociais, como um novo tipo de enfrentamento da questão social. Assim, as condições de vida e trabalho dos trabalhadores jā não podem ser desconsideradas inteiramente na formulação de políticas sociais, como garantia de bases de sustentação do poder de classe sobre o conjun to da sociedade. O Estado busca enfrentar tambëm, através de medidas previstas nessas politicas e concretizadas na aplicação da legislação e na implementação dos serviços sociais, o processo da pauperização absoluto ou relativo do crescente con tingente da classe trabalhadora urbana, engrossado com a expansão industrial, como elemento necessärio à garantia dos ní veis de produtividade do trabalho exigidos nesse estägio de expansão do capital. Ao referir-se à classe trabalhadora, engloba-se aí tanto a parcela dessa classe diretamente inserida no mercado de trabalho, como aquela excedente para as necessi dades médias de exploração do capital: o exército industrial de reserva. Este segmento de trabalhadores, não podendo sobre viver principalmente de salärio, enquanto está socialmente im possibilitado de produzi-1o, passa a depender da renda de to das as classes. A sociedade é obrigada a ocupar-se com a manu tenção dessa parcela da classe trabalhadora alijada do merca- 
do de trabalho. Os capitalistas, embora impelidos a partilhar dos custos de reprodução dessa população, tentam, na medida do possível, desincumbir-se de tal ônus, ampliando a pauperização desses trabalhadores "livres", e socializando os custos de reprodução desse segmento da classe trabalhadora para o conjunto da sociedade, no que as politicas sociais dos Estados capitalistas desempenham um papel fundamental. Isto sem relegar a necessidade política de contenção e controle de pos síveis insubordinações do conjunto da população trabalhadora submetida a um processo intenso de exploração.

Assim, à medida que avança o desenvolvimento das forças produtivas, da divisão do trabalho e a sua consequente potenciação, modificam-se as formas e o grau de exploração da força de trabalho. (ㅇ) Modifica-se, concomitantemente, o posicionamento das diversas frações da classe dominante e suas formas de agir face à questão social, no que entram em cena os interesses econômicos específicos desses grupos e a Iuta pelo poder existente no seu interior. As respostas à ques tão social sofrem alterações mais significativas nas conjuntu ras de crise econômica e de crise de hegemonia no bloco do po der.

Historicamente, passa-se da caridade tradicio nal levada a efeito por tímidas e pulverizadas iniciativas das classes dominantes, nas suas diversas manifestações filantrópicas, para a centralização e racionalização da atividade assistencial e de prestação de serviços sociais pelo Estado, à medida que se amplia o contingente da classe trabalhadora e sua presença política na sociedade. Passa o Estado a atuar sistematicamente sobre as sequelas da exploração do trabalho expressas nas condições de vida do conjunto dos trabalhadores.

(8) Ver K. Marx: El Capital. Crítica de la Economía Política, op. cit., t. I, seção IV 
O que merece ser marcado é que a evolução da questão social apresenta duas faces, indissociäveis: uma, con Eigurada pela situação objetiva da classe trabalhadora, dada historicamente, face às mudanças no modo de produzir e deapro priar o trabalho excedente, como frente à capacidade de organização e luta dos trabalhadores na defesa de seus interesses de classe e na procura de satisfação de suas necessidades ime diatas de sobrevivência; outra, expressa pelas diferentes maneiras de interpretä-la e agir sobre ela, propostas pelas diversas frações dominantes, apoiadas no e pelo poder do Estado.

Mais além das especificidades dessas formas de enfrentamento da questão social - que necessitam ser reti das, dado seu inestimável valor heurístico para a compreensão da atuação do Serviço Social -- o que se encontra subjacente e as unifica é a contradição fundamental que expressa a desigualdade inerente à organização vigente dessa sociedade: o trabalho social e a apropriação privada das condiçōes e dos frutos do trabalho, que se traduz na valorização crescente do capital e no crescimento da miséria relativa do trabalhador.

O Serviço Social no Brasil afirma-se como pro fissão, estreitamente integrado ao setor püblico em especial, face à progressiva ampliação do controle e do âmbito da ação do Estado junto à sociedade civil. Vincula-se, também, a orga nizações patronais privadas, de caräter empresarial, dedicadas às atividades produtivas propriamente ditas e à prestação de serviços sociais à população. A profissão se consolida, então, como parte integrante do aparato estatal e de empresas priva das, e o profissional, como um assalariado a serviço das mesmas. Dessa forma, não se pode pensar a profissão no processo de reprodução das relações sociais independente das organizaçöes institucionais a que se vincula, como se a atividade pro fissional se encerrasse em si mesma e seus efeitos sociais de rivassem, exclusivamente, da atuação do profissional. Ora, sendo integrante dos aparatos de poder, como uma das catego- 
rias profissionais envolvidas na implementação de políticas sociais, seu significado social só pode ser compreendido ao levar em consideração tal característica.

o Serviço Social, embora regulamentado como uma profissão liberal, no paỉs não tem uma tradição de prātica peculiar às profissões liberais na acepção corrente do ter mo. O Assistente Social não tem sido um profissional autônomo, que exerça independentemente suas atividades, dispondo das condições materiais e tëcnicas para o exercício de seu traba tho e do completo controle sobre o mesmo, seja no que se refe re à maneira de exercê-lo, ao estabelecimento da jornada de trabalho, ao nível de remuneração e, ainda, ao estabelecimen to do "público ou clientela a ser atingida". (9) No entanto, se esta não vem sendo, historicamente, uma característica básica da profissão, ela não exclui, integralmente, certos traços que marcam uma prática "liberal" entre os quais se poderia arrolar: a reivindicação de uma deontologia (Código de Etica), o caráter não rotineiro da intervenção, viabilizando aos agentes especializados uma certa margem de manobra e de liberdade no exercício de suas funções institucionais. Outra característica a ser ressaltada é a existência de uma relação singular no contato direto com os usuários -- os "clientes"-- que reforça um certo espaço para a atuação tēcnica, abrindo a possibilidade de se reorientar a forma de intervenção, conforme a maneira de se interpretar o papel profissional. A is so se acresce outro traço peculiar ao Serviço Social: a indefiniçäo ou fluidez do "que é" ou do "que faz" o Serviço So-

(9) Segundo Mills, a característica básica do profissional liberal tradicional $\overrightarrow{\mathrm{e}}$ a independência no exercício de suas atividades. Contrapõe o profissional independente, figura da antiga classe media, ao profissional assalariado, categoria integrante dos white collars ou nova clas se média. Não se pretende incorporar integralmente a concepção desse au= tor, que, conforme ele pröprio explicita, trabalha à base de conceitos de origem weberiana. Ver C.W. Mills. A Nova classe media. Rio de Janeiro, Zahar, 1969, capitulos 4, 6 e 16 . 
cial, abrindo ao Assistente Social a possibilidade de apresen tar propostas de trabalho que ultrapassem meramente a demanda institucional. Tal caracteristica, apreendida às vezes como um estigma profissional, pode ser reorientado no sentido de uma ampliação de seu camp de autonomia, de acordo com a concepção social do agente sobre sua prätica. Resta salientar ainda que a definição jurídica do Serviço Social como profissão liberal abre possibilidades de seu exercício independente, apesar de serem restritas tais experiências face ao panorama do mercado de trabalho especializado no país.

Dentre as organizações institucionais que me diatizam o exercício profissional, cabe ao Estado uma posição de destaque, por ser, tradicionalmente, um dos maiores empregadores de Assistentes Sociais no Brasil. Ao considerar-se o Estado, é necessärio acentuar sua importância decisiva na reprodução das relações sociais, na sua condição de legislador e de controlador das forças repressivas. Estes dois "braços" do Estado são mutuamente complementares na tarefa de assegurar o poder e a ordem estabelecida conforme os interesses dominantes. (10) O Estado, como centro de exercício do poder po lítico, é a via privilegiada através da qual as diversas frações das classes dominantes, em conjunturas histöricas especí ficas, impõem seus interesses de classe ao conjunto da sociedade, como ilusörio interesse geral. Sendo a noçâo de Estado inseparävel da de dominação, importa reter o movimento contradi-

(10) "A que se deve imputar a perenidade (aparente) das relações de produção? Serā ao Estado, na sua condição de legislador, organizador do sistema contratual e institucional, sempre perfectível, pelo menos aparentemente, ou então ao Estado enquanto capacidade repressiva que detém o exército, a polícia, os serviços especiais ou meios de constrangimentos? (...) Aos dois, enquanto fatores complementares e fatores da ordem es tabelecida (...) A capacidade legislativa e contratual não é nada sem repressão. O Estado dispõe destes dois membros, destas duas mãos, destes dois braços armados; é no nível do Estado político que se situam os pensamentos estratégicos que utilizam, bem ou mal, consciente ou inconscien te, as forças econömicas, sociais, ideolögicas e políticas de que os ato res dispëm". H. Lefebvre. "Estrutura...", op. cit., p. 244. 
tôrio através do qual é exercida. No interior da classe domi nante encontram-se presentes interesses divergentes entre suas frações, que lutam entre si pelo controle do poder e pela apropriação de maior parcela possível do excedente produzido sob as formas de lucro industrial e comercial, juros e renda da terra. O Estado supõe, pois, uma aliança de segmentos sociais, cujos interesses são conflitantes, embora não antagôni cos. Porém, se o poder de Estado exclui as classes dominadas, não pode desconsiderar totalmente suas necessidades e interes ses como condição mesma de sua legitimação. Assim, o Estado vê-se obrigado, pelo poder de pressão das classes subalternas, a incorporar, ainda que subordinadamente, alguns de seus inte resses, desde que não afetem aqueles da classe capitalista co. mo um todo, dentro de um "pacto de dominação". (11) As relações sociais explicam, pois, o Estado. Na prática da dominação política deve ser considerado, ainda, o conjunto de meios de direção moral. e intelectual de uma classe sobre o conjunto da sociedade, ou seja, a forma pela qual é possível realizar sua hegemonia, ultrapassando as entidades estritamente governamentais, para abarcar a própria sociedade civil. Configurase, ai, o que Gramsci denomina "Estado Integral" ou "amplia ção do Estado". (므)

(11) L. Kowarick. "Proceso de desarrollo del Estado en América Lati na y políticas sociales". Acción Crítica n 5, Lima, CELATS/ALAETS, abr. 79, p. 6-13.

(12) Para o enriquecimento do tema em debate reconhecemos a importân cia de uma reflexão mais aprofundada sobre o significado do Estado no cā pitalismo monopolista, dado o caráter polêmico da questão expresso na $1 \overline{1}$ teratura especializada. Fugindo aos limites deste trabalho desenvolvê-10, remetemos os interessados a bibliografia que se segue: A. Gramsci. Maauiave1, a bolítica e o Estado Moderno. Rio de Janeiro, Civilização Brasileira, 1978. 3a. ed.,; H. Portelli. Gramsci e o bloco histórico. Rio de Janeiro, Paz e Terra, 1977; V. I. Lenin. O Estado e a revoluçáo: 0 Conceito marxista de poder. Rio de Janeiro, Diālogo Livraria, s.d.; K. Marx. O Dezoito Brumario de Luís Bonaparte. In: K. Marx e F. Engels. Tex tos 3. Sao Paulo, Ed. Sociais, 1977; N. Poulañtzas. Poder político Classes sociais. São Paulo, Martins Fontes, 1977; idem, O Estádo em Crise. Rio de Janeiro, Graal, 1977; R. Milliband. El Estado en là sociedad capitalista. Mexico, Siglo XXI, 1976; J. O'Comnors. USA: A Crise do ES- 
Essas consideraçōes sobre o Estado adquirem especial relevo para a compreensão do carăter da demanda e das fontes de legitimidade desse profissional face às persona gens sociais presentes nas condições que circunscrevem sua prätica. O processo de institucionalização do Serviço Social como profissão dentro da divisão social do trabalho encontrase estreitamente vinculado ao crescimento das grandes institui ções de prestação de serviços sociais e assistenciais, geridas ou subsidiadas pelo Estado, que viabilizam a expansão do mercado de trabalho para estes trabalhadores especializados. A isto se aliam as alterações implantadas pelo empresariado, relativas à administração e gerência das relações industriais. Passam a lançar mão de técnicos qualificados na ärea de "rela ções humanas" -- entre eles o Assistente Social -- para a implementação de políticas de pessoal, face a necessidade de ra cionalização da produção e do trabalho, exigidas pelo aprofun damento do processo de industrialização nos moldes do grande capital. Ã vigilẩncia dos operärios no interior da fäbrica passam a ser articulados mecanismos de persuasão que contribuam para a garartia da organização e regulamentação das rela ções de trabalho, no sentido de adaptar o trabalhador aos novos métodos de produção que potenciem a extração de trabaliho excedente.

Em suas origens no Brasil, o Serviço Social está intimamenté vinculado a iniciativas da Igreja, como parte de sua estratégia de qualificação do laicato, especialmente de sua parcela feminina, vinculada predominantemente aos setores abastados da sociedade, para dinamizar sua missão política de apostolado social junto às classes subalternas, particularmen

tado capitalista. Rio de Janeiro, Paz e Terra, 1977; L. Althusser. Ideologia e anarelhos ideolôóicos do Estado. São Paulo, Martins Fontes, s. d., N. Bobbio, et alii. O Marxismo e o Estado. Rio de Janeiro, Graal, 1979; H. Lefebvre. "Sociologia Política: A Teoria do Estado." In Sociologia de Marx. Rio de Janeiro, Forense, 1968. 
te junto à família operäria. Essa origem confessional, articu lada aos movimentos de Ação Social e Ação Católica, conforma um tipo de legitimidade ă profissão cujas fontes de justifica ção ideológica encontram-se na doutrina social da Igreja. Con figura-se, assim, um carăter missionärio à atividade profissional, como meio de fazer face aos imperativos da justiça e da caridade, dentro da perspectiva de profissionalização do apostolado social segundo paràmetros técnicos e modernìzadores, numa sociedade secularizada, ameaçada pelo liberalismo e pelo comunismo. Se esta é a fonte legitimadora da formação des se profissional nos seus primórdios, ela não se choca com o crescente aproveitamento e cooptação desse agente pelo aparato de Estado e pelo empresariado, que progressivamente văo atribuindo novas determinações à legitimação e institucionali zação do Serviço Social. O Estado passa a ser, num certo lapso de tempo, uma das molas propulsoras e incentivadoras desse tipo de qualificação técnica, ampliando seu campo de traba1ho, conforme estratégias estabelecidas pelos setores dominan tes para o enfrentamento da questão social, consolidadas em medidas de politica social. O Assistente Social passa a rece ber um mandato diretamente das ciasses dominantes para atuar junto à classe trabalhadora. A demanda de sua atuação não deriva daqueles que são o alvo de seus serviços profissionais -- os trabalhadores -- mas do patronato, que é quem dire tamente o remunera, (13) para atuar, segundo metas estabeleci das por estes, junto aos setores dominados. Estabelece-se, en tão, uma disjunção entre intervenção e remuneração, entre quem demanda e quem recebe os serviços do profissional. o que deve ser ressaltado é que esse profissional, embora trabalhe

(13) Tal afirmativa não implica o desconhecimento de que a remuneração recebida por esse trabalhador qualificado tem sua origem no valor criado pela classe trabalhadora em geral, que é quem produz a riqueza so cial. O que se procura marcar $\bar{e}$ que, à diferença de outros profissionaís liberais, o Assistente Social não recebe um pagamento diretamente daquele a quem se aplicam seus serviços. 
a partir e com a situação de vida do trabalhador, não é por ele diretamente solicitado; atua junto a ele a partir de uma demanda, que na maioria das vezes não é dele. A demanda dos serviços profissionais tem, pois, un nitido caräter de classe, o que fornece, por sua proximidade estreita com o Estado, um certo carăter "oficial" ao mandato recebido. Passa o pro. fissional a dispor de um suporte jurídico-institucional para se impor face ao "cliente", mais alēm de sua solicitação, res tando ao usuärio aceitar ou não os serviços prestados, não podendo deles se subtrair. O caminho que percorre o cliente até o profissional è mediatizado pelos serviços sociais prestados pelos organismos que contratam o profissional, os quais são, em geral, o alvo da procura do usuärio. Porém, para obtế-los, é obrigado a passar pelo Assistente Social, enquanto um dos agentes institucionais que participa da implementação de tais serviços. Este caráter de cunho impositivo que marca grande parte da atuação do profissional não aparece límpiảa mente no discurso da instituição Serviço Social. Ao conträrio, tende a expressar-se na representação dos profissionais ao reverso, como reforço à ideologia do desinteresse, do altruísmo, do dom de si, do respeito à livre iniciativa do cliente, do princípio da não ingerência, da neutralidade, etc. Essa linguagem característica de certo tipo de Iiteratura especializada é tỉpica de profissões réferidas à opções vocacio nais, que se constituem em seus primórdios, a partir de ações benemerentes e filantrópicas, que valorizavam - primado de ser -- as qualidades pessoais, jdeolögicas, filosóficas e especialmente morais de seus adeptos -- sobre oprimado do saber. A vocação de servir é concebida, nessa perspectiva, como uma escolha, oriunda de um chamado, justificado por motivações de ordens éticas, religiosas ou políticas, a que sö podem aderir indivíduos dotados de certas aptidões particulares e dispostos a engajar a totalidade de suas vidas em um projeto que, 
antes de ser trabalho, é uma missão. (14) Dessa imagem social, historicamente plasmada e frequentemente incorporada pelos postulantes à profissão e mesmo por profissionais, deriva um certo carăter missionário da figura do profissional, expressiva em suas origens, mas ainda vigente, talvez, atravës de uma roupagem mais secularizada: não mais o discurso carregado de linguagem explícita do apostolado cristão, mas do agente voltado para a ajuda aos demais, a serviço do povo, do oprimi do. Essa insígnia do despojamento que marca o profissional po de contribuir, ainda, para embaçar na e para a sua consciên cia as reais implicações de sua condição de trabalhador assalariado, fragilizando a luta sindical, o processo de organiza ção da categoria profissional, pela defesa de seus direitos trabalhistas e reivindicações salariais.

o trabalho do Assisiente Social se insere numa relação de compra c venda de mercadorias em que sua força de trabalho é mercantilizada. Aí se estabelece uma das linhas divisōrias entre a atividade assistencial voluntária, desenca deada por motivações puramente pessoais e idealistas, e a ati vidade profissional que se estabelece mediante uma relação contratual que regulamenta as condições de obtenção dos meios de vida necessārios à reprodução desse trabalhador especializado. Passa esse agente a perceber um salārio, preço de sua mercadoria força de trabalho em troca de sexviços prestados, determinado como o preço de qualquer outra mercadoria, ingres sando sua atividade no reino do valor. Uma das pré-condições para tal ingresso e a transformação de sua força de trabalho em mercadoria e de seu trabalho em atividade subordinada à classe capitalista, para efetivar-se à medida que, conforme o jâ acentuado, não se afirma historicamente como uma profissão liberal.

(14) Ver, a respeito, J. Verdès-Leroux. Le Travail social. Paris, Minuit, 1978, especialmente capítulo III, p. 101-9. 
0 alvo predominante do exercício profissional é o trabalhador e sua familia, elemento mais vital e significativo do processo de produção. I dele ou, mais precisamente, de sua força de trabalho em ação, que depende não apenas a transferência do valor coritido nos meios de produção ao produ to, mas a criação de novos valores, os quais são realizados a travếs da venda das mercadorias. Mais explicitamente: a força de trabalho em ação é a fonte de toda a riqueza social. À medida que o exercício do Serviço Social estä circunscrito dentro do contexto referente às condições e situação de vida da classe trabalhadora, encontra-se integrado ao processodecria ção de condições indispensáveis ao funcionamento da força de trabalho, à extração da mais-valia. (15) Participa, ao lado de outras profissões, da tarefa de implementação de condições necessárias ao processo de reprodução no seu conjunto, integra da como está à divisão social e técnica do trabalho. A produ ção e reprodução.capitalista inclui, também, uma gama de atividades, que, não sendo diretamente produtivas, são indispensáveis ou facilitadoras do movimento do capital. São funções que, com o progresso da divisão do trabalho, se desmembraram de outras, adquirindo uma existência independente, substantivadas como função específica de deteŕminados agentes a que está diretamente encomendada. Embora não sejam geradoras de valor, tornam mais eficiente o trabalho produtivo, reduzem o limite negativo colocado à valorização do capital, não deixando de ser para ele uma fonte de lucro. E o que ocorre, por exemplo, com a maioria das atividades ligadas ao comércio. Existem, ain da, muitas atividades caracterizadas por se dedicarem, espe cialmente, à criação de bases para o exercício do poder de classe, que tem sua expressão mäxima no Estado. São ativida-

\footnotetext{
(15) Em caräter preliminar, poder-se-ia afirmar que o Serviço Social não e uma profissão que se inscreva, predominantemente, entre as ativida des diretamente vinculadas ao processo de criação de produtos e cle va= lór. O trabalho dó Assistente Social seria, então, dominantemente, : um trabalho improdutivo.
} 
des diretamente vinculadss ao controle politico-ideolögico e/ ou repressivo e à modernização do aparato burocrático do Esta do, necessärios à garantia do domínio de classe. Deste ponto de vista, são funções cujo significado econômico estâ subordi nado a seu caräter político determinante. Sua razão de ser $\vec{e}$ dada pela contribuição que possam oferecer, à medida que se encontram vinculadas a estruturas do poder, à criação de condições político-ideológicas favoráveis à manutenção das relações sociais, configurando-se como harmônicas, naturais, destituídas das tensões que lhe são inerentes. Tratam, ainda, de reduzir as arestas da realização problemática da expansão do capital, determinada pela lei geral da acumulação: a reprodução ampliada da riqueza, apropriada privadamente e da miséria coletiva dos produtores diretos. Em outros termos: tratam de centrar esforços na busca de um equilíbrio tenso entre capital e trabalho, na ärdua tarefa de conciliar o inconciliável. Assim, à proporção que encetam esforços no sentido de manter a continuidade da organização social dentro da ordem do capital, contribuem, inevitavelmente, para reproduzir as contradi ções fundamentais que conformam as relações sob as quais se baseia essa sociedade. E dentro desse quadro geral que se pre tende situar o Serviço Social.

o profissional de Serviço Social é, aqui, tam bém considerado na sua condição de intelectual. Para caracterizā-1o, busca-se suporte em Gramsci, (16) para quem essa categoria não constitui um grupo autônomo e independente das classes fundamentais; ao contrário, tem o papel de dar-1hes homogeneidade e consciência de sua função, isto $\vec{e}$, de contribuir na luta pela direção social e cultural dessas classes na sociedade. Trata-se do "organizador, dirigente e tëcnico" que coloca sua capacidade a serviço da criação de condições favoráveis à organização da própria classe a que se encontra vin

(16) Ver, especialmente, A. Gramsci. Obras escolhidas. v. II, Lisboa. Estampa, Coleção Teoria $n^{\circ} 22$, 1974. p. 189-215. 
culado. A medida que expressa uma identidade pela consciência e pela prática com essas classes, são orgânicos, organicidade que é tanto maior quanto mais intima a conexão com uma classe fundamental (burguesia ou proletariado).

Porém, em sua auto-representação, os intelectuais tendem a considerar-se como independentes das classes essenciais, o que, segundo o autor citado, não $\overrightarrow{\mathrm{e}}$ mais que ex pressão de uma utopia social, uma vez que cada classe cria sua própria categoria de intelectual, a cujos interesses se encontra estritamente vinculado.

A categoria específica de intelectual de novo tipo da sociedade moderna està vinculada à educação técnica, tí pica do mundo industrial. Seu modo de ver e de atuar jă não se reduz à eloquência, mas envolve-se, diretamente, na vida cotidiana, como "organizador, construtor, persuasor permanente". Dessa forma, além da atividade técnica propriamente dita, executa um trabalho organizativo e articulador das "massas" aos grupos sociais a que se encontram ligados; atividade essa que se orienta para a criação de condições favoráveis ao domínio dessa classe. Nesse sentido, são organicamente vinculados aos grupos fundamentais, tendo seu desempenho voltado para contribuir na luta pela hegemonia da classe a que serve. A relação dos intelectuais com o processo de valorização do capital não é direta, mas mediatizada por todo o contexto social. $\underline{(17)}$

$\mathrm{Na}$ atividade intelectual pode-se distinguir diferentes graus: "os criadores dos valores, das ciências, ar tes e filosofia" e os "administradores e divulgadores da riqueza intelectual existente, tradicionalmente acumulada." (18)

(17) "A relação entre os intelectuais e o mundo de produção não é imediata, como acontece com os grupos sociais fundamentais, mas é mediata, em diversos graus por todo o tecido social, pelo conjunto das sobre-estruturas, do qual os intelectuais são precisamente os "funcionários." A. Gramsci. Obras..., op. cit., p. 198.

(18) A. Gramsci. Obras..., op. cit., p. 200. 
O Assistente Social, que na sua qualidade de intelectual tem como instrumento básico de trabalho a linguagem, poderia ser caracterizado nesse segundo grupo. Historicamente, näo consti tui atividade proeminente para essa categoria profissional a produção de conhecimento científicos. Emerge e se afirma em sua evolução como uma categoria voltada para a intervenção na realidade, utilizando-se dos conhecimentos socialmente acumulados e produzidos por outras ciências, aplicando-os à realidade social para subsidiar sua prätica.

A consideração do Assistente Social como um intelectual subalterno situa, necessariamente, a reflexão de seu papel profissional numa dimensão eminentemente política, estando em jogo o sentido social da atividade desse agente. Coloca de frente indagações como: a quem vem efetivamente ser vindo esse profissional, que interesses reproduz, quais as possibilidades de estar a serviço dos setores majoritários da população?

o Serviço Social em sua trajetória não adquire o status de ciência, o que não exclui a possibilidade e necessidade de o profissional produzir conhecimentos científ cos, contribuindo para o acervo das ciências humanas e sociais, numa linha de articulação dinâmica entre teoria e prática. A divisão de trabalho entre as ciências, a segmentação entre teoria e prática, ciência e têcnica, são expressões da crescente divisão de trabalho intelectual e manual, que se desenvolve à medida que se aprofunda o capitalismo. Indepen dentemente do referendum à orientação positivista que procede à fragmentação da realidade em detrimento da apreensão da uni cidade e das leis do movimento do concreto, é inegável que a divisão do trabalho engendra especialidades e especialistas, alêm de fragmentar o pröprio homem no ato mesmo de produzir, tornando-o um trabalhador parcial, uma peça do trabalho coletivo. Estabelece a segmentação entre as ciências, as tecnologias, que adquirem, inclusive, uma de suas expressões na dị 
versidade de ocupações vigentes no mercado de trabalho. Den tro desse panorama vigente na sociedade, poder-se-ia caracterizar o Serviço Social como uma tecnologia social, e o profis sional como um técnico cuja atuação è geralmente mediatizada pela prestação de serviços sociais em instituições que implementam politicas sociais especificas, sendo nesse sentido relevante indagar-se sobre o significado desses serviços na sociedade vigente.

\subsection{O Significado dos Serviços Sociais}

A expansão dos serviços sociais no século XX estā estreitamente relacionada ao desenvolvimento da noção de cidadania. (19) Com a generalização da economia mercantil e a necessāria afirmação da liberdade individual como condição de funcionamento da nova organização da sociedade, vai adquirin do forma a noção de igualdade de todos os homens perante a lei, com direitos e obrigações derivados de sua condição de participantes integrais da sociedade, ou seja, de cidadãos. A relação contratual se generaliza: afirmam-se os direitos civis e políticos, mas os direitos sociais só adquirem ' tal status no século atual. Antecedido de leis beneficentes, entre as quais se destaca a "Lej dos Pobres" na Inglaterra, a conquista dos direitos sociais é perpassada pela luta contra o estigma do assistencialismo, presente até os nossos dias.

(19) Segundo Narsha11, o conceito de cidadania compreende três elementos inter-relacionados, cujo desenvolvimento, porém, não coincide no tempo: o elemento civil, composto dos direitos necessärios $\mathbf{a}$ liberdade individual (de ir e vir, de imprensa, de pensamento e o direi to à proprie dade e de concluir contratos válidos), e o direito de justiça; o elemen= to político compreende o direitode participar do poder político, seja como participante de um organismo investido de autoridade política, seja como eleitor; e, finalmente, o elemento sucial,"que se refere a tudo o que vai desde o direi to a un mínimo de bem-estar econômico e segurança ao direito de participar, por completo, naherança social e levar uma vida de um ser civilizado de acordo com os padröes que prevalecem na sociedade. As institui ções mais intimamente ligadas a ele são o sistema educacional e os serviços sociais".T.H. Marsha11. "Cidadania e classe social." In: Cidadaria, clas. se social e "status". Rio de Janeiro, Zahar, p. 57-114. 
"A poor law tratava as reivindicações dos pobres não como parte integrante de seus direitos de cidadãos, mas como uma altermativa deles -- como reivindicações que poderiam ser atendidas somente se deixassem de ser cidadãos. (...) 0 estigma associado à assistência aos pobres exprimia os sentimentos profundos de um povo que entendia que, aqueles que aceitavam assistên cia, deviam cruzar a estrada que separava a comnida= de dos cidadãos da companhia dos indigentes." (20)

A incorporação dos direitos sociais à noção de cidadania começa com o desenvolvimento da escola primäria püblica e se expande, principalmente, à medida que o liberalis mo vai perdendo terreno e o Estado assume progressivamente os encargos sociais face à sociedade civil.

0 que merece ser ressaltado é que a sociedade do capital supõe uma contradição inevitável na sua continuida de: o discurso da igualdade e a realização da desigualdade. De um lado a abirmação da liberdade individual e da igualdade de direitos e deveres de todos os cidadãos, como condição de funcionamento pleno da economia de mercado. E a igualdade necessă ria a toda troca de mercadorias equivalentes, através da relação en tre livres proprietārios das mesmas. E a relação igualitâria que aparece na esfera da circulação consubstanciada, também, nos textos legais. Em pólo oposto, tem-se a desigualdade inerente à organizaçäo da sociedaide como unidade de classes sociais distintas e antagônicas assentada em uma relação de poder e exploração. E a desigualdade inerente à relação do capital, ao "livre direito de propriedade", que só é desvendado ao se analisar o que ocorre com os agentes sociais na produção so cial da riqueza, contraposta a sua apropriação privada.

Em outros termos, a noção de cidadania e da igualdade que the acompanha, de igual participação de todos os indivíduos na sociedade, tem como contrapartida as classes so ciais em confronto, que convivem numa relação desigual, tanto

(20) T. H. Marshall. "Cidadania...", op. cit., p. 72. 
econômica quanto política. Uma é condição de existência da ou tra, embora se neguem mutuamente: a igualdade e a desigualdade, a cidadania e as classes sociais, como pölos da mesma moe da. E os "direitos sociais" têm por justificativa a cidadania, embora seu fundamento seja a desigualdade de classes. (21)

Ora, os serviços sociais são uma expressão con creta dos direitos sociais do cidadão, embora sejam efetiva mente dirigidos aqueles que participam do produto social por intermédio da cessão de seu trabalho, jä que não dispõem das condições necessärias à realização de seu trabalho. São servi ços a que têm direito todos os membros da sociedade na qualida de de cidadãos; mas são serviços que vêm suprir as necessida des daqueles cujo rendimento é insuficiente para ter acesso ao padrão médio de vida do "cidadão"; são, portanto, a esses efe tivamente dirigidos e por eles consumidos predominantemente.

Mas o que significam os serviços sociais, mais além de serem expressão dos direitos sociais? Como se situam no conjunto da sociedade?

A riqueza social existente, fruto do trabalho humano, è redistribuida entre os diversos grupos sociais sob a forma de rendimentos distintos: o salärio da classe traba1hadora, a renda daqueles que detêm a propriedade da terra, o Iucro em suas distintas modalidades (industrial, comercial) e os juros daqueles que detêm o capital. Parte da riqueza so

(21) Tal questão è colocada por Marsha11 ('Cidadania..., op. cit.,), embora seja desenvolvida e encaminhada a partir de outros parânetros ana líticos. A indagação é proposta pelo autor nos seguintes termos: "Se a cí dadania tem sido uma instituição em desenvolvimento na Inglaterra, pe menos durante a metade do século XVII, então é claro que seu crescimento coincide com o desenvolvimento do capitalismo, que é o sistema não de igualdade, mas de desigualdade. Eis o que necessita de explicação. Como è possível que estes dois principios opostos possam florescer lado a 1ado, no mesmo solo? O que fez com que eles se reconciliassem e se tornassem, ao menos por algum tempo, aliados ao invés de antagonistas? A questão è pertinente, pois não hă dưvida de que, no sêculo $X X$, a cidadania e o sis tema de classe capitalista estão em guerra" (p. 76). 
cialmente gerada $\vec{e}$ canalizada para o Estado, principalmente sob a forma de impostos e taxas pagos por toda a população. Assim, parte do valor criado pela classe trabalhadora e apro priado pelo Estado e pelas classes dominantes é redistribuído à população sob a forma de serviços, entre os quais os servi ços assistenciais, previdenciārios ou "sociais", no sentido amplo. Assim $\vec{e}$ que tais serviços nada mais são, na sua real $i-$ dade substancial, do que uma forma transfigurada de parcela do valor criado pelos trabalhadores e apropriado pelos capitalistas e pelo Estado, que $\bar{e}$ devolvido a toda a sociedade (em especial aos trabalhadores, que deles mais fazem uso) sob a forma transmutada de serviços sociais. Reafirmando: tais serviços, püblicos ou privados, nada mais são do que a devolu çäo à classe trabalhadora de parcela mínima do produto por ela criado mas não apropriado, sob uma nova roupagem: a de serviços ou benefícios sociais. Porém, ao assumirem esta forma, aparecem como sendo doados ou fornecidos ao trabalhador pelo poder politico diretamente ou pelo capital, como expres são da face humanitāria do Estado ou da empresa privada. Os diversos serviços sociais previstos em políticas sociais espe cíficas são a expressão de conquista da classe trabalhadora em sua luta por melhores condições de trabalho e de vida, que são consubstanciadas e ratificadas atravês da legislaçãu social e trabalhista. A generalização dos serviços sociais expressa, portanto, vitórias da classe operária na luta pelo reconhecimento de sua cidadania na sociedade burguesa, mais do que a manifestação de um possível espírito solidārio e humanitário de um caricato Estado de Bem-estar Social. No entan to, existe uma outra face da mesma questão que deve ser ressaltada: ao defrontar-se com o processo de organização da classe operária, o Estado e as classes patronais incorporam e encampam como suas uma sërie de reivindicações da classe trabalhadora em sua luta de resistência face ao capital e de afirmação de seu papel como classe na sociedade: defesa de sa lários reais, direito à educação, saủde, cultura, etc. Tais re 
vindicações, ao serem absorvidas pelo Estado e pela classe pa tronal, através de suas organizações privadas, passam a ser devolvidas aos trabalhadores sob forma de beneficios indiretos, organizados e centralizados em instituições assistenciais e, agora, outorgados mediante uma estrutura burocratiza da, sob o controle do Estado. Assim procedendo, não só debilí tam o componente autônomo e, portanto, o caráter de classe das lutas operärias esvaziando-as, como tambēm reorientam : a seu favor o conteúdo e os ganhos da mesma. Passam a utilizar tais conquistas como meio de interferir e de mobilizar contro ladamente os movimentos sociais, ao mesino tempo em que deslocam as contradições do campo explícito das relações de classe, absorvendo-as dentro das vias institucionais. As expressões de luta de classe se transformam em objetos de assistência social, e os serviços sociais que são expressão de direitos sociais dos cidadãos, transmutam-se em matéria-prima da assistência. Explicitando: o que é direito do trabalhador, reconhecido pelo próprio capital, $\vec{e}$ manipulado de tal forma, que se torna um meio de reforço da visão paternalista do Está do.

Portanto, se tais serviços, de um lado, favorecem os trabalhadores, como resultante de suas próprias conquistas no sentido de suprir necessidades básicas de sobrevivência nessa sociedade, por outro lado, sua implementação, ao ser mediatizada e gerida pela classe capitalista, passa a se constituir em um dos instrumentos políticos de reforço do seu poder, face ao conjunto da sociedade. Torna-se um meio de não só manter a força de trabalho em condições de ser explorada produtivamente, evitando alterações substanciais na política salarial que afetem a lucratividade dos empresários, como, e principalmente, um instrumento de controlar e prevenir possiveis insubordinações dos trübalhadores que escapem ao domínio do capital. Passam, ainda, a ser utilizados como suportes materiais de um discurso ideológico que fortalece a divulgação 
de um modo de vida, dado pelo capital, para a classe trabalha dora, elemento básico à ação de impor a interiorização das re lações sociais vigentes.

\subsection{Relações Sociais e Serviço Social}

As reflexões anteriores encaminham à formulação de hipóteses diretrizes norteadoras da anālise, construídas a partir de um modo peculiar de encarar o cbjeto de estudo: a profissão de Serviço Social no contexto de aprofundamen to do capitalismo monopolista na sociedade brasileira. Estas hipöteses, sinteticamente, enunciadas, são, a seguir, desenvolvidas em seus elementos teórico-constitutivos.

Poder-se-ia afirmar que o Serviço Social, como profissão inscrita na divisão social do trabalho, situa-se no processo da reprodução das relações sociais, fundamentalmente como uma atividade auxiliar e subsidiäria no exercicio do con trole social e ná difusão da ideologia da classe dominante junto à classe trabalhadora. Assim, contribui como um dos mecanismos institucionais mobilizados pela burguesia e inserido no aparato burocrático do Estado, das empresas e outras entidades privadas, na criação de bases políticas que legitimem o exercício do poder de classe, contrapondo-se às iniciativas autônomas de organização e representação dos trabalhadores. In tervêm, ainda, na criação de condiçöes favorecedoras da repro dução da força de trabalho, atravês da mediação dos serviços sociais, previstos e regulados pela política social do Estado, que constituem o suporte material de uma ação de cunho "educa tivo", exercido por esses agentes profissionais. Porëm, como o processo de reprođução das relações sociais é, também, o processo de reprodução das contradições fundamentais que as conformam, estas se recriam e se expressam na totalidade das manifestações do cotidiano da vida em sociedade. A instituição Serviço Social, sendo ela própria polarizada por interesses de classes contrapostas, participa, também do processo social; 
reproduzindo e reforçando as contradiçöes bäsicas que conformam a sociedade do capital, ao mesmo tempo e pelas mesmas ati vidades em que é mobilizada para reforçar as condiçc̄es de dominação, como dois polos inseparāveis de uma mesma unidadc. E a existência e compreensão desse movimento contraditório que, inclusive, abre a possibilidade para o Assistente Social colocar-se a serviço de um projeto de classe alternativo àque le para o qual é chamado a intervir. Sendo o agente profissio nal um intelectual mediador de interesses de classes em luta pela hegemonia sobre o conjunto da sociedade, a prätica profissional é, visceralmente, permeada por esse jogo de forças, subordinando-se, historicamente, àquelas que são dominantes do ponto de vista político, econômico e ideológico, em conjun turas históricas determinadas. Embora constituída para servir aos interesses do capital, a profissão não reproduz, monoliti camente, necessidades que lhe são exclusivas: participa, também, ao lado de outras instituiços sociais, das respostas às necessidades legitimas de sobrevivência da classe trabalhadora, face às suas condições de vida, dadas historicamente. Os movimentos sociais autônomos constituem a forma politicamente legítima de organização e mobilização dos trabalhadores, como meio de expressão e enfrentamento coletivo de suas necessidades e interesses de classe no cenärio político; outra forma de enfrentamento dessas necessidades de sobrevivência é a bus ca de acesso aos recursos sociais existentes, através dos equipamentos coletivos, instituídos e mantidos pelo poder vigente, como meio de fazer face aos direitos já : conquistados pela classe trabalhadora, na sua luta de resistência ao capita1. Porém, ao serem tais respostas mediatizadas por organismos institucionais com um nítido caráter de classe, as "soluções" propostas para as necessidades de sobrevivência dessa população passam a ser subordinadas aos objetivos político-econômicos dos setores sociais que controlam tais entidades.As condições de vida dos trabalhadores passam a constituir-se em meio de implementação de uma estratêgia política, do exercício 
de poder de clase, e os agentes profissionais tendem a se tor nar agentes mediadores dos interesses desse poder sobre a população, dentro dos requisitos estabelecidos pelo "pacto de dominação". Não se pode menosprezar, nesse contexto, o poder de pressão exercido pelos movimentos políticos das classes su balternas sobre essas instituições, o que se traduz, muitas vezes, em modificações operadas nas estratégias, programas e serviços estabelecidos pelas mesmas. Tais mudanças expressam a correlação de forças entre as diversas classes e suas frações, que conformam um perfil peculiar a conjunturas histōri cas determinadas, como expressão da luta de classe.

Dentro dessa perspectiva, cabe ressaltar a $\underline{\text { bi }}$ gura do agente profissional, como sujeito participe desse pro cesso. No desempenho de sua função intelectual, o Assistente Social, dependendo de sua opção política, pode configurar - se como mediador dos interesses do capital ou do trabalho, ambos presentes em confronto, nas condições em que se efetiva a prá tica profissional. Pode tornar-se intelectual orgânico a serviço da burguesia ou das forças populares emergentes; pode orientar a sua atuação reforçando a legitimação da situação vigente ou reforçando um projeto político alternativo, apoian do e assessorando a organização dos trabalhadores, colocandose a serviço de suas propostas e objetivos. Isso supõe, evidentemente, por parte do profissional, uma clara compreensão teórica das implicações de sua prática profissional, possibilitando-1he maior controle e direção da mesma, dentro de limi tes socialmente estabelecidos. Por outro lado, supõe, ainda, uma clara subordinação do exercício técnico-profissional às suas consequências políticas: aí, o carāter propriamente técnico subordina-se à dimensão política dessa prática. Portanto, trata-se da necessidade de uma reflexão sobre o caráter político da prática profissional, como condição para o estabeleci mento de uma estratégia teórico-prática que possibilite, dentro de uma perspectiva histórica, a alteração do carāter de classe da legitimidade desse exercício profissional. 
Considerando que o Serviço Social, no processo de reprodução das relações sociais, não se situa unilate ralmente como un mecanismo de apoio ao capital, podendo tor nar-se um instrumento a serviço dos trabalhadores, cabe, no entanto, apreender na história dessa instituição na sociedade brasileira, qual tem sido sua tônica predominante. No estabelecimento dessa tendência dominante, intervêm vários fatores, alèm das determinações estruturais que estabelecem os limites dentro dos quais a profissão pode mover-se. Entre eles cabe ria reafirmar: o jogo das forças sociais que reflete a articu lação das classes e de suas frações na luta pelo poder e pela hegemonia, conformando os värios momentos conjunturais e as respostas dadas pela categoria profissional aos novos desafios que the são apresentados, nos diferentes momentos históricos. Essas respostas estão condicionadas pelo nível de desenvolvimento teörico-prático obtido pelo Serviço Social, pe10 peso das värias correntes profissionais e políticas existentes no interior dessa instituição, que conformam diferentes maneiras de interpretar o papel do profissional e da profissão, presentes em confronto no meio profissional.

A revisão da trajetória do Serviço Social no Brasil conduz a afirmar que, considerando o antagonismo da re lação capital e trabalho, a tencência predominante, no que se refere à inserção da profissão na sociedade, vem sendo, histo ricamente, o reforço dos mecanismos do poder econômico, politico e idenlögico, no sentido de subordinar a população traba lhadora às diretrizes das classes dominantes em contraposição $\bar{a}$ sua organização livre $e$ independente. Tal subordinação è mediatizada pela integração da "clientela" aos aparatos instí tucionais através dos quais se exerce o controle social, tornando-se esse profissional assalariado um agente auxiliar a serviço da racionalização de serviços prestados por essas organizações e intermediário entre elas e a população. Porẻm,se esta tem sido, historicamente, a direção principal e predomi- 
nante dessa prätica institucional, ela nao $\vec{e}$, cristalinamente, refletida na literatura especializada. Verifica-se uma defasa gem entre os efeitos sociais objetivos da prätica profissional e as representações que legitimam esse fazer, expressas atra vês de um discurso marcado por um tônus humanitārio e moderni zador, o que não exclui seu conteúdo de classe, embora tenda a encobri-1o. Contribui, assim, para mistificar para o prôprio agente profissional as implicações históricas de sua prâa tica. Percebe-se que o discurso da instituição Serviço Social è mais límpido quanto à intenção de seu fazer, nos seus primór dios. A proporção que avança a acumulação e com ela a moderni zação do Estado e a consequente burocratização das atividades, aquele discurso vai se tornando cada vez mais tëcnico e racio nal, com uma aparência "neutra" e "apolítica". Mas, ao mergulhar-se mais além das aparências e ao confrontar o código com - fazer efetivo, historicamente situado, torna-se possivel desvendá-10, apreendendo os compromissos com interesses de classe que essa prática traz subjacente.

As hipóteses aqui apresentadas acentuam, por tanto, a relação do Serviço Social face à reprodução do con trole social, da ideologia dominante, da força de trabalhc e das contradições inerentes às relações sociais vigentes. Tais aspectos ressaltados são inseparāveis, enquanto dimensões dis tintas de um mesmo fazer profissional. Não se trata de trabalhar duas ou mais vezes, para obter resultados diversos visto que os pontos colocados em relevo são resultados contrapostos de uma única e mesma atividade: da prática profissional do As sistente Social. A distinção estabelecida é apenas abstrata, para fins analíticos, sendo que, de acordo com as circunstâncias do trabalho profissional, pode haver ênfase em uma ou ou tra forma de inserção do Serviço Social no processo de reprodução das relações sociais. Essa expressão do trabalho colet vo $\vec{e}$, pois, pensada na globalidade de suas implicações, a par tir das contradições da sociedade que se traduzem na prática dessa instituição. 
A seguir, as hipöteses apresentadas sâo desen volvidas em seus elementos fundamentais, caracterizando-os con conceitualmente. Reafirmamos, pois, que as distinções feitas no tocante ao Serviço Social e reprodução da força de traba1ho, do controle e da ideologia, são meramente abstratas, orientadas no sentido de facilitar a exposição.

\subsubsection{Serviço Social e Reprodução da Força de Trabalho}

A sobrevivência e a reprodução da classe tra balhadora na sociedade capitalista dependem fundamentalmente do salário que o trabalhador recebe em troca da venda de sua força de trabalho no mercado; is to porque trata-se de traba1hadores assalariados, despojados dos meios de produção e dos meios de vida, os quais se encontram monopolizados pelos proprietários do capital e da terra.

E do rendimento do trabalhador, is to é, do salārio, que depende, portanto, a satisfação das necessidades básicas do produtor direto e de sua familia, tais como: alimentação, saūde, lazer, habitação, educação, etc. E o preço da força de trabalho é socialmente determinado considerandose ó mínimo indispensável para cobrir as necessidades conside radas básicas em cada momento histórico particular, de acordo com o nível de desenvolvimento alcançado pela sociedade.

Como a reprodução da força de trabalho está na dependência direta do salārio, qual o significado dos serviços sociais mantidos pelo Estado ou pelas instituições privadas nessa reprodução?

A resposta a essa indagação è uma condição pa ra se apreender o significado da atividade profissional do As sistente Social, do ponto de vista da reprodução das condições de sobrevivência da classe trabalhadora. Isto porque a atuação profissional é, geralmente, mediatizada pelos servi- 
ços sociais prestados atravës de aparatos institucionais aos quais se vincula o profissional por meio de um contrato de trabalho, enquanto um dos participantes da implemeirtação de políticas sociais e do planejamento e execução de atividades por elas previstas. Assim, as reflexões efetuadas a partir dos serviços sociais são extensivas à profissão, à medida que aqueles constituem a retaguarda de recursos ou suporte material para o exercício profissional.

A tentativa de encontrar a resposta à indagação supra-mencionada conduz a caminhos que ajudam a desvendar a relação entre salārio e acumulação.

Embora, à primeira vista, salārio e acumulação sejam duas magnitudes independentes uma da outra, tratase na realidade da relação entre trabalho retribuído e não pa go da mesma população trabalhadora. 0 salário supc̃e sempre a entrega de trabalho excedente aos proprietärios do capital, trabalho este que é a substância mesma do processo de acumula ção. Assim é que a elevação do "preço do trabalho" não elimina a exploração, podendo, no entanto, reduzir seu grau ao au mentar a parcela de trabalho pago apropriado pelo trabalhador. (22) Porém, o que determina os movimentos de alta e baixa dos salários è o ritmo da acumulação. (23) Em alguns momen tos, o crescimento do capital pode tornar a força de trabalho explorável insuficiente, fazendo com que o aumento da demanda de trabalho eleve os salários. Entretanto, tão logo isto acon tece, a causa da elevação dos salários desaparece. Assim é

(22) "O fato de que o trabalho suba de preço por efeito da acumulação do capital só quer dizer que o volume e o peso das cadeias de ouro que o trabalhador assalariado forjou para si mesmo, apenas permitem que fique menos rigidamente acorrentado." K. Marx. E1 Capital. Crítica de 1a Economia Polîtica, op. cit., t. I, cap. XXIII, p. 521-2. (23) "(..) Para dizer em termos matemáticos: a magnitude da acumula ção e a variävel independente; a magnitude do salärio a variável depen= dente e não vice-versa." K.: Marx. EI Capital. Crítica de la Economía Política, op. cit., p. 523. 
que o próprio processo de produção capitalista faz com que o "preço do trabalho" ou, mais precisamente, da força de trabatho retorne ao nível que corresponde às necessidades do capital. No entanto, a própria lei que reage a acumulação exclui toda elevação do preço do trabalho que possa colocar seriamen te em perigo a reprodução do prôprio regime de capital, já que, aí, o trabalhador existe para reproduzir a riqueza e não esta para atender as necessidades daqueles que a criam.

Como o trabalho excedente ou mais-valia é a prôpria substância da acumulação, é evidente que qualquer ele vação de salārio acima das necessidades médias do capital interfere no montante de trabalho não pago a ser apropriado pela classe capitalista. Ou, em outros termos, a redução do piso salarial é um dos principais mecanismos tradicionalmente utilizados pelos capitalistas para ampliar sua lucratividade e que tem, como contrapartida, o aumento da taxa de exploração da classe trabalhadora e a consequente redução de seu nível de vida. Por outro lado, ocupa um lugar de destaque na história da classe trabalhadora na sociedade moderna a luta, através de seus organismos sindicais, pelo "justo preço do trabalho", o que só é arrancado da classe capitalista através do peso da pressão organizada.

Face ao crescente processo de expropriação a que estão submetidos os trabalhadores no movimento de expansão do capital, sua pauperização tende a aumentar em relação ao crescimento acelerado do capital. Diante dessa lei da acu mulação, o Estado, em seu "papel de árbitro das relações de classe", assume tarefas cada vez mais ativas no sentido de zelar pela reprodução da força de trabalho, não só através de legislação específica -- expressão muitas vezes de ganhos efe tivos da classe operāria -- como através da prestação de serviços básicos por intermédio de organismos estatais, para-estatais ou privados, regulados através de políticas sociais. 
Se a politica salarial é o elemento determinante do nível de vida da classe trabalhadora na sociedade ca pitalista, é, portanto, o elemento mais fundamental de qualquer política social. Porêm, no discurso do capital e do Esta do, a política salarial é abstraída e segmentada do conteúdo das chamadas politicas sociais. O que se encontra subjacente a essa fragmentação é a preservação do "direito natural" dos detentores dos meios de produção de garantirem suas taxas de lucratividade e de exploração do trabalho, seja diretamente, seja por intermédio de seus porta-vozes a nível de Estado, fí xando eles proprios os níveis salariais e regulando as relações de trabalho. Assim, as polł̈ticas sociais e os serviços delas derivados são relegados a dimensões particulares e particularizadas da situação da vida dos trabalhadores: saúde, habitação, educação, alimentação, etc., subordinadas às es tra tégias político-econômicas que sustentam o processo de reprodução ampliado do capital.

Do ponto de vista do capital, essas medidas colaboram no sentido de socializar parcela dos custos de reprodução da força de trabalho, partilhando-os com toda a popu lação, que os assume indiretamente via impostos e taxas reco lhidos pelo poder püblico. Tais serviços, ainda quando mantidos por empresas privadas e fornecidos a baixo custo ou em pa gamentos facilitados aos empregados, são vantajosos para o ca pital, porque seu custo é partilhado pelos próprios beneficia rios. Na linguagem do poder, os "benefícios sociais" são algu mas vezes denominados "salārio indireto", jā que são encarados como uma "complementação salarial", preferível à elevação dos salários reais, à proporção que podem ser descontados total ou parcialmente dos benefíciáriosoude impostos governamentais. Os serviços sociais tornam-se, portanto, um meio de reduzir os custos de reprodução da força de trabalho.

Em segundo lugar, poder-se-ia ressaltar que a rede de serviços sociais viabiliza ao capital uma ampliação de 
seu campo de investimentos, subordinando a satisfação das ne cessidades humanas à necessidade de reprodução ampliada do ca pital. As respostas às exigências básicas da reprodução da ví da da classe trabalhadora, social e historicamente definidas, são transformadas, pela lógica que preside o processo de valo. rização, num meio de diversificação dos ramos de aplicação pro dutiva do capital. Assim, a qualidade dos serviços prestados subordina-se ao imperativo da rentabilidade das empresas. Na perspectiva da classe capitalista, a filantropia é redefinida: a "ajuda" passa a ser concebida como investimento, que $\vec{e}$ o princípio que preside a organização dos serviços sociais.

Dentro da ótica do capital, os serviços sociais tornam-se, ainda, um reforço para a garantia dos elevados niveis de produtividade do trabalho exigidos pela elevação da composição orgânica do capital. Contribuem para manter um equilíbrio psicofísico do trabalhador, canalizando e antecipando a emergência de focos de tensão, que afetem a paz social necessária à potencialização do processo de exploraçãodo trabalho. Alguns tipos desses serviços -- ensino profissionalizante, por exemplo -- estão voltados, ainda, para propiciar uma qualificação da força de trabalhc, exigida de parcela da classe trabalhadora, para fazer frente ao crescente processo de especialização da produção.

Uma outra contribuição efetiva propiciada à classe capitalista pela infra-estrutura de serviços sociais, mantidos pelo Estado, $\vec{e}$ a colaboração prestada na manutenção de condições subsidiärias à sobrevivência do exērcito industrial de reserva. A existência da superpopulação relativa é uma das condições do regime capitalista de produção gerada pe. la pröpria força expansiva do capital, que tende a realizarse alterando a composição orgânica média do capital. Se esta é a característica que se observa nos ramos mais avançados da produção, ou seja, naqueles em que hă maior emprego de capital em meios de produção (máquinas, matérias-primas e instru- 
mentos de trabalho aperfeiçoados) em proporção à força de tra balho viva, não se pode esquecer de que, em outros ramos, o desenvolvimento da produção tem ainda por base prioritariamen te uma ampla absorção de mão-de-obra.

o que importa destacar é que o exército indus trial de reserva, à medida que estabelece uma maior competição entre os próprios trabalhadores, contribui para a redução dos salärios, ao fazer a oferta de mão-de-obra crescer em re1 ação à demanda. Assim, as medidas assistenciais voltadas para auxiliar a reprodução dessa parcela da classe trabalhadora, alijada do mercado de trabalho, vem responder a interesses substanciais da classe capitalista, no sentido de garantir uma oferta abundante e permanente de força de trabalho a baixo custo. Não se pode esquecer que a força de trabalho em ação ē a fonte de valor e propriedade do capitalista e, portanto, fonte de valor para os representantes do capital. Deve-se destacar, ainda, que a pauperização acentuada determina um ambiente fértil à emergência de utopias, de inconformismos que são, potencialmente, ameaçadores à ordem vigente. Controlar e prever as ameaças tem sido uma estratégia política do poder.

Assim como os serviços sociais têm para os ca pitalistas um caräter complementar à reprodução da força de trabalho a menor custo, para os trabalhadores assalariados tais serviços são tambēm complementares na sua reproduçäo bi sica, intelectual e espiritual e de sua famellia, jā que a base de sua sobrevivência depende da venda de sua força de trabalho. Ainda que complementares, não significam que sejam absolutamente secundārios, especialmente face à política de con tenção salarial que mantēm o salärio real aquém do necessārio à satisfação das necessidades básicas de reprodução da família trabalhadora, como alternativa para a elevação da taxa lucro. Tal tendência é acentuada nos períodos cíclicos de crise eco- 
nômica em que as condições de vida da classe trabalhadora atingem dimensões críticas.

Para a parcela do exército industrial de reserva, qualificada por Marx como o "pauperismo oficial" aquele segmento da classe trabalhadora que perdeu a base da obtenção de seus meios de vida, isto é, a venda de sua força de trabalho - - tais serviços deixam de ser apenas complementa res, tornando-se vitais, embora não suficientes, diante da inexistência de outros meios de sobrevivência. Refere-se, aqui, às "vítimas da grande indüstria": mutilados, doentes, velhos, viưvas, etc., cuja sobrevivência esta em certa propor ção na dependência dos benefícios obtidos através da previdência social ou em outras formas de assistência püblica ou privada.

Portanto, do ponto de vista dos representantes do trabalho pode-se afirmar, preliminarmente, que os serviços sociais respondem a necessidades legítimas, à medida que são, muitas vezes, temas de lutas político-reivindicatórias da classe trabalhadora, no empenho de terem seus direitos sociais reconhecidos, como estratégia de defesa de sua pröpria sobrevivência.

Como esses serviços sociais, na implementação dos quais atua o Assistente Social, ingressam no processo de reprodução da força de trabalho e, mais amplamente, das relações sociais?

Os referidos serviços ingressam no consumo da classe trabalhadora, que, sob certo ponto de vista, é um consumo produtivo. Para o trabalhador esse consumo não é mais que meio de sobrevivência de sua pessoa e de sua família. Já para o Estado e para os capitalistas é um consumo produtivo, no sentido de que contribui para reproduzir o trabalhador como um trabelhador assalariado, divorciado das condições de trabalho, sempre disposto a vender parte de si mesmo para sub 
sistir. Reproduz, assim, a força viva de trabalho como fonte de riqueza para aqueles que a adquirem e não para aqueles que a desgastam. Embora em caräter subsidiário, tais serviços con tribuem para a produção e reprodução do meio de produção indispensävel ao processo produtivo: o próprio trabalhador.

Caberia indagar, finalmente, sobre a "eficiên cia" dos serviços sócio-assistenciais para a atenuação dos efeitos do processo expropriativo a que se encontra submetida a grande parcela da população.

Assim como esses serviços têm sua justificati va histórica na desigualdade estrutural que permeia a socieda de de classes, têm, também, seus limites dados pelo pröprio regime de produção, que, devido à sua natureza, permite, no máximo, a redução da exploração e não sua eliminação. A política social que orienta o aparato burocrätico-legal que imple menta os serviços sociais é estabelecida e controlada pelo po der do Estado, existindo, prioritariamente, para assegurar as condições bäsicas indispensäveis ao dominio do capital no con junto da sociedade. Ora, é a nível do Estado que se situam as estratëgias políticas que orientam a reprodução das relações sociais. Assim, as políticas "assistenciais", de "promoção so. cial" ou de "bem-estar social", como se queira rotular, embora dirigidas à classe trabalhadora, interpretam os interesses dessa classe, segundo a visão dos grupos que controlam o Esta do. Orientam-se no sentido de integrar à sociedade a população trabalhadora "assistida", o que, em outros termos, signibica integrā-la $\bar{a}$ ordem estabelecida pelo capital: $\bar{e} a$ integraçäo ao sistema de dominaçäo na sua condição de dominada. Um dos resultados que se obtēm, através de muitos desses serviços, é a institucionalização, pelo Estado, da pobreza, trans 
formando o que era "um problema social" em uma questão sob controle. $(24)$

Os limites das politicas de "bem-estar social" são dados ainda pelas crises periódicas que acompanham inevitavelmente a realização do capitalismo mundial, durante as quais os problemas sociais se agudizam.

A anảlise da profissão de Serviço Social na ötica de sua inserção na sociedade capitalista tem sido pouco explorada na literatura profissional. Alguns trabalhos pionei ros (25) tendem a acentuar as relações entre o Serviço Social e a reprodução da força de trabalho, embora os autores assina lem de passagem que os assistentes sociais "atuam, tambëm, co mo agentes ideológicos da burguesia, rompendo a luta reivindi cativa dos trabalhadores". Mas esse aspecto não $\vec{e}$ desenvolvido nos trabalhos referidos. E esta dimensão político-ideológi ca que pretendemos recuperar e desenvolver a seguir.

(24) "No caso da assistência à pobreza, o resultado final a que se ašsiste não e e a eliminação do fenômeno, mas ê antes a institucionalização da pobreza. Aquilo que inicialmente era um problema social, na medi da em que venha a ser institucionalizado, passa a ser uma questão so controle. Só o Estado vê os seus objetivos atendidos; em outros termos, a integração, pelo menos formalmente, está atingida." A. Rizzoli. "Assis tencialismo e marginalidade: o Serviço de colocação familiar em Saõ Car" los." Piracicaba, Dissertação de Mestrado, ESALQ/USP, 1978, p. 13.

(25) Poder-se-ia citar, por exemplo, os trabalhos de A. L. Maguiña e de J. Parodi, que têm o merito de ter levantado a questão da análise do Serviço Social na ötica da reprodução do capital. No entanto, importa acentuar que os artigos supracitados desenvolvem a análise a partir da profissão do Serviço Social, sem dar maior peso aos aparatos institucionais a que se encontra vinculada. Tal orientação analïtica, embora acentue diretamente o significado da profissão na sociedade capitalista, cor re o perigo de atribuir à profissáo um poder que não decorre dela mesmā exclusivamente, mas sim dos aparatos de poder a que se encontra vinculada. Ver, a respeito, A. L. Maguiña. 'Trabajo Social: Servicio o actividad produtiva?" Acción Crïtica n. 3, Lima, CELATS/ALAETS, 1977, p. 17-26; J. Parodi. "E1 Significado de1 Trabajo Social en el Capitalismo y la Reconceptualización." Acción Crítica n. 4, Lima, CELATS/ALAETS, 1978, p. 3343. 
4.4.2. Serviço Social e Reprodução do Controle e da Ideologia Dominante

Essa dimensão privilegiada na anālise da inserção do Serviço Social no processo de reprodução das relações sociais deve se $x$ apreendida dentro dos reais limites em que se encontra circunscrita a prätica profissional. Não se trata de superestimar a importância ou a força dessa profissão como un dos mecanismos mobilizados por aqueles setores so. ciais que a legitimam e a demandam, dentro de uma estratēgia de reforço do controle social e da difusão da ideologia dominante. O Serviço Social è considerado, portanto, como um instrumento auxilian e subsidiärio, ao lado de outros de maior eficăcia política e mais ampla abrangência, na concretização desses requisitos bäsicos para a continuidade da organização social vigente. Isso, no entanto, não minimiza o esforço de inserir a reflexão sobre a profissão na direção apontada, pro curando apreender as implicações histöricas desse tipo de intervenção na realidade, inscrita dentro de um projeto de clas se. Para o desenvolvimento da anälise, nessa perspectiva, $\overrightarrow{\vec{e}}$ oportuno retomar e ampliar algumas considerações anteriormente expressas sobre as relações de apropriação e dominação na sociedade capitalista, situando, a partir das mesmas, o Serviço Social face à reprodução do controle social e da ideologia.

. Conforme jă foi acentuado, a produção e repro dução da riqueza é um processo eminentemente social, à medida que se realiza atravês de relações sociais que são engendradas e recriadas no interior do amplo processo da produção social. O capital, demiurgo da economia moderna, é antes de tudo uma relação social que supõe, como parte de si mesmo e como seu antagônico, o trabalho assalariado. E a acumulação do capital, apreendida em seu constante renovar-se, é um processo de reprodução ampliada não só do valor, mas das relações de classes em que se situam os agentes sociais fundamentais desse processo: o capitalista e o trabalhador assalariado, 
apreendidos não apenas individualmente, mas enquanto personificam categorias econômicas que determinam sua posição no pro cesso produtivo.

A medida que o capital só se nutre de mais-va lia -- isto é, de trabalho excedente não pago, apropriado do trabalhador desprovido dos meios de produção e de vida -- o confronto entre os agentes sociais é permeado por uma luta in finda na defesa de seus interesses antagônicos: o que é substância e condição do crescimento do capital é parte do próprio processo vital do trabalhador. Este se desgasta e se empobrece como meio de subsistir e, no mesmo ato, enriquece o capitalista e recrudesce as condições que reproduzem sua pröpria situação de classe. $\underline{(26)}$

O desenvolvimento das forças produtivas num contexto de aprofundamento do capitalismo abrange, cada vez mais, ramos diversificados da produção, que vão sendo subsumi dos de modo real ao capital. (27) A expansão do capital supõe, portanto, o desenvolvimento extensivo do proletariado, a intensificação do processo de trabalho e, consequentemente, da exploração. Essa maneira de se efetivar o desenvolvimento eco nômico faz com que se desenvolvam, concomitantemente à amplia ção das relações de dominação e exploração, as condições obje tivas que viabilizam a maturação politica dos trabalhadores e o desenvolvimento de sua consciência de classe. Porëm, se, de

(26) A noção de situação de classe é, assim, explicitada por Florestan Fexnandes: "De acordo com a concei tuação de Marx, a situação de uma classe social è definida pela posição ocupada, em conjunto, pètos seus membros no processo de produção econômica. Colocando grupos de indivíduos em condiçoes economicas fundamentaImente semelhantes, a situação de classe favorece o desenvolvimento de um paratelismo de interesses e da origem a ações convergentes ou anälogas, que podem inclusive assumir a forma de atuação conscỉente (organização parcial ou total das atividades da classe)". Florestan Fernandes. "A Anälise Sociológica das Classes Sociais." In: Ensaios de Sociologia geral e aplicada. São Paulo, Pioneira, 1976, 3a. ed., cap. 2, p. 73.

(27) Sobre a noção de subsunção formal e real do trabalho ao capital ver especialmente K. Marx. El Capital - Libro I, capitulo VI (Inédito), op. cit., p. 54-77. 
um lado, são dadas as condições objetivas que viabilizam o avanço da luta de classes, por outro lado, $\vec{e}$ preciso acentuar que o modo como se organiza a produção determina aparências ratificadoras de seu funcionamento, que tendem a encobrir as relaçöes desiguais em que se sustentam. Se ë na pröpria organização social que se incrusta a fonte do poder e da exploração de classe, o processo social não revela a natureza das re lações sociais de modo imediato, porque estas não são relações diretas, "transparentes", mas mediatizadas pela mercadoria e pelo dinheiro. O trabalho alienado, que estabelece a relação invertida de sujeição do homem às coisas, é obscurecido pelas mistificações que se formam no movimento do capital, que fazen ressaltar as relações entre coisas, entre produtos, en de trimento das relações sociais entre os homens, que se expressam atravês de produtos-mercadorias.

0 modo capitalista de produzir supc̈e, pois, um "modo capitalista de pensar", (28) que expressa a ideolologia dominante, na sua força e nas suas ambiguidades. Esse modo de pensar necessário à "reelaboração das bases de susten tação - ideológicas e sociais -- do capitalismo", é recriado

(28) "Entendo que o modo capitalista de produção, na sua clássica, $\vec{e}$ também um modo capitalista de pensar e deste não se (...) Enquanto modo de produçáo de idëias, marca tanto o senso acepçäo separa comern quanto o conhecimento científico. Define a produção de diferentes modali dades de idéias necessárias à produção de mercadorias em condições de ex ploração capitalista, da coisificaçăo das relações sociais e de desumañi zação do homem. Não se refere estritamente ao modo como pensa o capita = lista, mas ao modo de pensar necessário à reprodução do capitalismo, à reelaboração de suas bases de sustentação ideológicas e sociais. 0 modo capitalista de pensar está determinado, não obstante, pelas contradições do capitalismo, fato que se reflete nas suas ambiguidades e dilemas. E c que leva para o conhecimento do senso comm e para o conhecimento cientí. fico as tensões do capitalismo, expressas nas diferenciações ideológicas e de tendēncias dentro da mesma formação social. E que leva, enfim o capitalismo para o pensamento de outras classes, como a pequena burguesia, o proletariado, os proprietários de terra (...)" J.S. Martins. Sobre o modo capitalista de pensar. São Paulo, Hucitec, Coleção Ciências Socíaís, Serie Linha de Frente, 1978, p. XI e XII. 
a partir do modo de produzir a riqueza material, da reprodução do modo de vida instituído pelo capital.

A economia capitalista, quando comparada a pe ríodos histöricos anteriores, prescinde de laços extra-econômicos de dependência pessoal, jâ que a pröpria lei da oferta e procura estabelece uma dinâmica "natural" às relações econô mico-sociais. Porēm, não prescinde de novas formas de controle social que garantam e fortaleçam o "consensus" social. E indispensävel um mínimo de unidade na aceitação da ordem do capital pelos membros da sociedade, para que ela sobreviva e se renove. A medida que não existe sociedade baseada na pura violência, é necessārio recorrer à mobilização de outros meca nismos normativos e adaptadores que facilitem a integração social dos cidadãos e a redução do nível de tensão que permeia as relações antagônicas. A burguesia tem no Estado, enquanto órgão de dominação de classe por excelência, o aparato privilegiado no exercício do controle social, $\underline{(29)}$ embora aí não se esgote, abarcando as instituições da sociedade civil.

(29) Nos termos do es tudo clásśico de Lênin, o Estado é assim carac terizado: "Segundo Marx, o Estado é um organismo de dominação de classe", um organismo de opressão de una classe por outra; é a criação de uma "ordem" que legaliza e fortalece esta opressão, diminuindo o conflito de classes (...). O Estado é o produto e a manifestação de que as contradições de classe são inconciliâveis. O Estado surge no momento e na medida em que, objetivamente, as contradições de classe não podem conciliar-se. E inversamente: a existência do Estado prova que as contradições de clas se são inconciliäveis (...) Como o Estado nasceu da necessidade de refrear as oposições de classe, mas como nasceu, ao mesmo termo, em meio ao conflito dessas classes, ele é, via de regra, o Estado da classe mais poderosa, daquela que domina do ponto de vista econômico e que graças a ele se torna tambem classe politicanente dominante e adquire assim novos mei os para explorar a classe oprimida". V. I.Lênin. O Estado..., op. cit., p. 25 e 31 . 
Porëm, o controle social (30) não se reduz ao controle governamental e institucional. I exercido, tambëm, através de relações diretas, expressando o poder de influência de determinados agentes sociais sobre o cotidiano de vida dos indivíduos, reforçando a internalização de normas e comportamentos legitimados socialmente. Entre esses agentes institucionais encontra-se o profissional do Serviço Social.

0 controle social e a difusão da ideologia do minante constituem recursos essenciais, complementando outras maneiras de pressão social com base na violência, para a obtenção de consenso social. Importa ressaltar que a ideologia dominante $\vec{e}$ um meio de obtenção do consentimento dos domina dos e oprimidos socialmente, adaptando-os à ordem vigente. (31) Em outros termos: a difusão e reprodução da ideologia ê uma das formas de exercício do controle social. Mas trata-se do uso que fazem da ideologia os grupos e classes que dis-

(30) 0 controle social, do ponto de vista sociológico, refere-se ao estudo dos modos como é exercida a pressão social, aqui apreendida como imposição e/ou persuasão orientada para a conformação dos agentes sociais à organização vigente da sociedade e ao poder de classe. Trata-se "do conjunto de métodos pelos quais a sociedade influencia o comportamento humano, tendo em vista manter determinada ordem." K. Mannheim. Sociologia sistemätica. (Uma Introdução ao Estudo de Sociologia). São Paulo, Pioneira, 1971. 2a. ed., p. 178.

(31) "A medida que não existe sociedade baseada na violência pura é e ideologia que obtem o consentimento dos oprimidos, dos explorados. A ideologia os representa de maneira ta1, que lhes extorque, alem da rique za materia1, a aceitação e mesmo a adesão espiritual. As ideologias de classe elaboram três imagens de classe que lutan pela dominação: uma ima gem por e para ela mesma, que a exalta; uma imagem dela mesma para os ou tros grupos e classes, que a engrandece; uma imagem das outras classes e grupos, que os deprecia diante de todos, as desvaloriza a seus próprios olhos, abate-os e faz deles vencidos antes do combate ou sem combate... Desta forma a burguesia elabora sua representação de si, para seu próprio uso: portadora da razão humana, logo da boa vontade e distinção, en fim da capacidade de bem organizar. Ela se apresenta às outras classes ă sua maneira: o bom e o mau operário, o "chefe" e o semeador da rebelião. Enfim, representa-se a si mesma para o uso de outras classes: o dinheiro empregado para o bem geral, para a felicidade humana, para a fecundidade e o progresso." H. Lefebure. "Sociologia do conhecimento e ideologia." In: Sociologia de Marx, op. cit., p. 55. 
põem do poder, na legitimação da estrutura social, jā que as idéias abstratas, em si s $\vec{o}$, são destituỉdas de qualquer força de poder. (32)

Porêm, várias ideologias ou concepções de mun do convivem em confronto e se reproduzem desde que exista o confronto objetivo das classes sociais que são seus portadores, uma vez que as representações nada mais são que a vida real tornada consciente. (33) A produção da consciência tem seu fundamento na prätica da vida social tal como ela se configura, historicamente. Expressa a maneira como a dinâmica so cial vem sendo apreendida pelos diversos agentes sociais, em dados momentos histöricos. Não se trata, pois, de uma representação ünica e homogênea para todas as personagens sociais, enquanto portadoras de diversos interesses de classe.

(32) As observações sobre ideologia retomam as considerações tecidas no primeiro capítulo sobre a mistificação do capital e se alicerçam ainda, principalmente, em K. Marx e F. Engels. A Ideologia..., op. cit., e em H. Lefebvre. "Sociologia..., op. cit.

(33) "A produção das idéias, das reprèsentações, da consciência, es tâ de início diretamente entrelaçada com a atividade material e com o intercânbio material dos homens, como a linguagem da vida real. 0 representar, o pensar, o intercânbio espiritual dos homens, aparecem aqui como emanação direta de seu comportamento material. O mesmo ocorre com a produção espiritual, tal como aparece na linguagem da política, das leis, da moral, da religiăo, da metafísica, etc., de un povo. Os homens são os produtores de suas representações, de suas idéias, etc. Mas os homens mais ativos, tal como se acham condicionados por un determinado desenvolvimen to de suas forças produtivas e pelo intercâmbio a que ele corresponde até chegar às suas formações mais amplas. A consciência jamais pode ser outra coisa que o ser consciente e o ser dos homens e o seu processo de vida real." K. Marx e F. Engels. A Ideologia..., op. cit., p. 36 e 37.0s grifos são nossos. 
Entretanto, näo se reduz ao extremo oposto de representações meramente individuais. (34) A ideologia vincula-se a classes sociais em luta pela hegemonia sobre o conjun to da sociedade. E aquelas que monopolizam a riqueza e o Esta do são, também, dominantes na configuração do modo de pensar necessário à reprodução da sociedade. O modo capittalista de reproduzir e o de pensar são inseparäveis, e ambos se expressam no cotidiano da vida social.

Assim como a sociedade encontra-se em permanente movimento, fazendo-se e transformando-se, a consciência também nunca é acabada, não se confundindo com um sistema petrificado de idéias. Encontra-se em permanente processo de constituição e renovação, processo esse que não estả isento das contradições existentes na base material da sociedade, as quais se expressam com maior ou menor intensidade na consciên cia dos grupos e classes sociais. Não existe a consciência "pura", na perspectiva de um "tipo ideal". Ora, se as representações são o "ser consciente dos homens, isto é, o seu pro

(34) Lefebvre esclarece a diferença entre a concepção da ideologia para os ideólogos franceses e para Marx-Engels. "Para os ideólogos franceses a ideologia se limitava à explicação, através de uma psicologia causal, das representaçōes individuais. Para Marx e Engels o objeto estu dado torna-se o conjunto das representações características de uma epocá ou de uma sociedade. Por exemplo, a ideologia alemä" (p. 42 e 43). 0 autor destaca, ainda, que não se deve confundir a ideologia com a represen tação coletiva de Durkheim. Enquanto este faz da sociedade um ser abstrāa to, para Marx ela nasce da prätica de indivíduos e grupos. A ideologia não pertence ao social em geral, mas a grupos (classes e castas) em luta para se afirmarem; não é exterior aos indivíduos, não dispondo, portanto, do poder de pressionar de fora sobre as consciências individuais. As ideologias têm suas exigências em relação às vidas individuais, porém são consentidas pelos indivíduos. "As ideologias fornecem a língua da vi da real e, por consequência, não exercem pressão do social sobre o indivíduo no sentido da sociologia durkheimiana... as ideologias como tais envolvem o individuo, conferem-1he um sentido (una significação e uma orientação). De fora a ideologia aparece como un sistema fechado, coeren te. De dentro, ela se entrega à fê, à convicção, à adesão. 0 indivíduō consagra-se à ideologia e crê realizar-se nela. En vez de realizar-se, e le se perde, aliena-se" (p. 54). H. Lefebvre, "Sociologia...", op. cit. 
cesso de vida real", a consciência social, fundando-se na prâ tica histörica de uma sociedade, sỏ a refletiria, fielmente, quando as relações entre as pessoas fossem diretas e transparentes o que não se verifica na formação social vigente. A me diăa que, no capitalismo, o modo de viver e de produzir $\vec{e}$ per meado pela forma mercadoria, esta torna-se a mediadora, por excelência, das relações sociais, transformando-se na aparência de relações entre coisas. E, portanto, historicamente impossível que as representações reflitam de modo límpido: e cristalino a vida social, já que a própria consciência é permeada pela mercadoria e seu fetiche. Assim $\vec{e}$ que as representações tornam-se a expressão de um apreender parcial e mutila do da realidade, embora não totalmente falso ou ilusório. (35) A prōpria consciência das classes trabalhadoras não é imune às mistificações do capital e do capitalismo; caso conträrio, a sociedade não se reproduziria. Esse apreender parcial, mas nem por isso falso da realidade, è a forma necessăria da cons ciência se constituir e se expressar, porque è gerada no mesmo movimento em que se opera a produção e reprodução do capital, conforme já acentuamos anteriormente. Sua superação só pode se efetivar pela prätica política das classes sociais em confronto.

Ao ressaltar a força da ideologia na obtenção do consentimento dos oprimidos ao processo de exploração, à proporção que o encobre e o legitima, não se pode esquecer que a eficácia da ideologia è limitada: se encobre as contradições na e para a consciência, não as elimina. Assim è que, apesar da função legitimadora das relações sociais exercida pela ideologia, as contradições inerentes a essas mesmas rela

(35) Segundo Lefebvre, a teoria das ideologias recolhe da filosofia uma conquista fundamental: que a verdade sempre surge mesclada à ilusão e ao erro. Recorre a Hegel para afirmar: "O erro e a ilusão são momentos do conhecimento de onde se resgata a verdade". H. Lefebvre, "Sociologia...", op. cit., p. 61 . 
ções se reproduzem, sendo criadas e recriadas no decorrer mes mo do processo social.

Tendo por base estes parâmetros gerais, cabe a indagação: por que o privilegiamento da dimensão políticoideológica do Serviço Social em sua inserção no processo de reprodụção do Capital?

Os elementos substanciais que justificam tal posição adotada jä foram explicitados, mas agora reunidos con tribuem para uma maior clareza da exposição.

A profissão se institucionaliza dentro da di visão capitaísta do trabalho, como partícipe da implementa ção de políticas sociais específicas levadas a efeito por organismos püblicos e privados, inscritos no esforço de legitimação do poder de grupos e fraçōes das classes dominantes que controlam ou têm acesso ao aparato estatal. Na operacionaliza ção de medidas instrumentais de controle social, o emprego de tëcnicas e tecnologias sociais $\vec{e}$ largamente utilizado, enquan to meios de influenciar a conduta humana, adequando-a aos padrões legitimados de vida social, manipulando racionalmenteos problemas sociais, prevenindo e canalizando a eclosão de tensões para os canais institucionalizados estabelecidos oficial mente. Entre essas tecnologias encontra-se o Serviço Social.

A institucionalização das atividades assisten ciais a nível do Estado e a pröpria demanda de profissionais especializados para atuação nesse campo expressa, de um lado, a ampliação e intensificação das tensões sociais que acompanham o desenvolvimento social e a necessidade de mobilizar re cursos no sentido de atenuâ-las ou preveni-las, controlandoas segundo parâmetros de racionalidade e eficiência. De outro lado, expressa, tambëm, o reconhecimento oficial das diferenças sociais crescentes e da situação de pobreza de parcelas expressivas da população. Paradoxalmente, porêm, as medidas mobilizadas pelo Estado não são suficientes para alterar subs 
tancialmente as situações diagnosticadas à proporção que the cabe preservar os pilares da organização vigente da sociedade. Porém, as medidas acionadas são eficazes para um outro objeti vo: o contorno político dos "problemas sociais", abafando, mo mentaneamente, as tensões e estabelecendo ou fortalecendo vín culos de dependência da população carente para com o Estado através das instituições de cunho assistencial ou previdencia rio. Na busca de contornar a desigualdade econômica, reforçan do a "sensação" de uma participação mais efetiva do cidadão no poder e nos "benefícios" sociais, o que se obtém como resultado é a reprodução da desigualdade social e do poder segmentado de uma base legitimamente popular. Em suma, apesar de todas as medidas de controle, se acumulam e se reproduzem as expressões de antagonismo social; apenas suas eclosões se retardam ou se manifestam com uma roupagem, aparentemente, menos violenta.

As medidas de política social fornecem ao poder um argumento básico, na sua convivência política com os diversos grupos e classes sociais: seu. "interesse" e a sensibilidade para com os problemas sociais, em busca de um projeto humanizado de sociedade. Este discurso ideológico é estratégico para o reforço das bases políticas do poder junto àque les que não dispõem de canais efetivos de acesso a ele. Mas o discurso $\vec{e}$ rebatido pelo cotidiano do trabalhador, no qual o caráter desumano da organização social, mais além das propagandas político-ideológicas, se exprcssa na miséria de seu dia-a-dia e no trabalho alienado que só o escraviza, mortifica, parecendo-lhe algo estranho, que só lhe pertence enquanto sofrimento e desgaste pessoal.

Finalmente, importa ressaltar alguns traços característicos da prática institucional do Serviço Social, que tornam viável sua utilização pelo empresariado e pelo Estado, dentro de uma estratégia de dominação. 
O Assistente Social, no exercício de suas at vidades vinculado a organismos institucionais estatais, paraestatais ou privados, dedica-se ao planejamento, operacionalização e viabilização de serviços sociais por eles programados para a população. Exerce funções tanto de suporte à racionalização do funcionamento dessas entidades, como funções técni cas propriamente ditas. (36) O Assistente Social é chamado a constituir-se no agente institucional de "linhá de frente" nas relações entre a instituição e a população, entre os serviços prestados e a solicitação dos interessados por esses mesmos serviços. Dispõe de um poder, atribuído institucionalmente, de selecionar aqueles que têm ou não direito de participar dos programas propostos, discriminando, entre os elegíveis, os mais necessitados, devido à incapacidade da rede de equipamentos sociais existentes de atender todo o püblico que, teoricamente, tem acesso a eles. Nesse sentido, o profissional é solicitado, a intervir como "fiscalizador da pobreza", comprovando-a com dados objetivos e in loco, quando necessārio, evitando assim que a instituição caia nas "armadilhas da conduta popular de encenação da misëria", ao mesmo tempo em que procura garantir, dessa forma, o emprego "racional" dos recursos disponíveis. A demanda estä orientada, tambēm, no

(36) No exercício de suas funções, o Assistente Social realiza ativi dades como: seleção sőcio-econônica para fins de "elegibilidade" do usua rio, de acordo con as normas que regulam os serviços prestados, preparações dos "clientes" para seu "desligamento" da instituição ao término dos programas efetuados; interpretação das normas de funcionamento da entida de a população, explicitando seus direitos e deveres, cuja aceitação pré-condição para o acesso à programação da entidade; encaminhamento dos solicitantes a rede de equipamentos sociais existentes, articulando uma retaguarda de recursos para a instituição; atendimentos individuais e grupais para orientação dos usuärios face à necessidade por eles apresentada e/ou derivada de exigências do trabalho do pröprio órgão; trabalhos comunitärios; visitas domiciliares, treinamentos, organizaçăo de cursos, campanhas söcio-educativas; orientação e concessão de 'benefícios" sociais previstos na legislação previdenciäria/trabalhista, etc.; distribuição de auxílios materiais. Esta listagem de atividades, não pre tendendo ser exaustiva, permite dar uma idéia do tipo de tarefas mais cô mumente desempenhadas pelo profissional. 
sentido de contribuir para potenciar e agilizar os atendimentos, garantindo a produtividade do trabalho, quantitativamente avaliada, de modo a favorecer a rotatividade da população nos programas estabelecidos. Devido à proximidade com o usuário, o Assistente Social é tido como agente institucional que centraliza e circula informações sobre a situação social dos clientes para os demais técnicos e para a entidade, e as informações sobre o funcionamento desta para a população. A estas atividades é acrescida outra característica da demanda: a ação de persuadir, mobilizando o mínimo de coerção explícita para o máximo de adesão. Inclui-se, aí, a necessidade do usua rio ser levado a aceitar as exigências normativas e regulamen tares de funcionamento da entidade como as prioridades dos programas estabelecidos pelo órgão; a esta se soma a ação "educativa" que incide sobre valores, comportamentos e atitudes da população, segundo padrões söcio-institucionais dominantes. Importa que as diretrizes institucionais sejam transmitidas como nessärias e vālidas tanto para o "cliente", como para a garantia de eficiência dos serviços, transformando o carāter impositivo da normatização em algo internalizado e aceito voluntariamente por aqueles a quem se dirige e aos quais não foi dada a oportunidade de opinar. Por outro lado, a estratégia de individualização dos atendimentos possibilita aliviar tensões e insatisfações, efetivas ou potencialmente existentes, canalizando-as para sua neutralização dentro de medidas oficialmente estabelecidas, isto é, submetendo-as ao controle institucional.

Se estas são algumas características dessa prática profissional, para atender a demanda que the é efetua da, elas não esgotam o trabalho técnico, devendo ser ressalta dos outros elementos deste. O Serviço Social, como uma das formas institucionalizadas de atuação nas relações entre os homens no cotidiano da vida social, tem, como instrumento pri 
vilegiado de ação, a linguagem. (37) E este o meio privilegia do, através do qual se efetiva a peculiar açăo persuasiva ou de controle por este profissional. Embora os serviços sociałs sejam o suporte material e as entidades a base organizacional que condicionam e viabilizam a atuação técnica do Assistente Social, esta dispõe de características peculiares. Trata-se de uma ação global de cunino sócio-educativo ou socializado ra, voltada para mudanças na maneira de ser, de sentir, de ver e agir dos indivíduos, que busca a adesão dos sujeitos. (38) Incide tanto sobre questões imediatas, como sobre a visão global de mundo dos "clientes". Não sendo, no interior da categoria profissional, uniforme e unívoco o direcionamento dessa ação, ele tem sido orientado, predominantemente, por uma perspectiva de integração à sociedade. Isso não significa desconsiderar a existência de rumos alternativos, que recusam a incorporação da educação do opressor, perspectiva que é minoritária no conjunto do meio profissional, mas profundamente significativa, face a seu carāter inovador dentro da tradição conservadora da instituição Serviço Social.

O Assistente Social atua no campo social a partir de aspectos particulares da situação de vida da classe trabalhadora, relativos à saüde, moradia, educação, relações familiares, infra-estrutura urbana, etc. E a partir dessas ex pressões concretas das relações sociais no cotidiano da vida dos individuos e grupos que o profissional efetiva sua intervenção. Estando sua atividade referida ao cotidiano, enquanto produto histōrico e enquanto vivência pelos sujeitos, ele é aqui apreendido como manifestação da própria história, na qual

(37) "A linguagem é tão antiga quanto a consciência -- a linguagem é a consciência real, prâtica, que existe para os outros homens e tambëm para mum mesmo; e a linguagem nasce, como a consciência, da carência, da necessidade de intercâmbio com outros homens". K. Marx e F. Fingels. A Ideologia..., op. cit., p. 43.

(38) Essa caracterîstica è ressaltada por J. Verdès-Leroux. Travail..., op. cit., que situa o trabalho do Assistente Social no "campo da manipulaçao simbôl ica". 
os agentes a produzem e reproduzem, fazendo-se e refazendo-se nesse processo social. A compreensão do cotidiano não se reduz aos aspectos mais aparentes, triviais e rotineiros; se eles são parte da vida em sociedade, não a esgotam. 0 cotidia no é a expressão de um modo de vida, historicamente circuns crito, onde se verifica não sô a reprodução de suas bases, mas onde são, também, gestados os fundamentos de uma prática inovadora. Assim, o "cotidiano não está apenas mergulhado no falso, mas referido ao possive1. A descoberta do cotidiano é a descoberta das possibilidades da transformação da realidade. Por isso, a reflexão sobre o cotidiano acaba sendo crítica e comprometida com o possivel". (39) A crítica da vida cotidiana implica ultrapassar as aparências que a escamoteiam, para redescobri-la em toda a densidade do seu conteủdo histórico, a partir do desvendamento das formas pelas quais se expressa. 0 cotidiano é o "solo" da produção e reprodução das relações sociais. (40) 0 Assistente Social, através da prática direta junto aos setores populares, dispõe de condições potencialmen te privilegiadas de apreender a variedade das expressões da vida cotidiana, por meio de um contato estreito e permanente com a população. Sendo esta proximidade aliada a uma bagagem científica, que possibilite ao profissional superar o carăter pragmático e empirista que não raras vezes caracteriza sua intervenção, poderá obter uma visão totalizadora da realidade desse cotidiano e da maneira como é vivenciada pelos agentes sociais.

(39) J.S. Martins. Pronumciamento efetuado durante o curso de Sociologia da Vida Cotidiana para os alumos de graduação em Ciências Sociais da Universidade de São Paulo, em 11-03-75. (Anotação de aula).

(40) H. Lefebvre. "A Es trutura socia1: A Produção e reprodução das relaçōes sociais." In: Sociologia,... op. cit. Sobre a vida cotidiana ver as seguintes obras do autor: La Critique de la vie quotidienne. (2 vols.) , Paris, $L{ }^{\prime}$ Arche, 1958; La Vida cotidiana en è mindo moderno. Madri, Alianza, 1972. A incorporaçao da dumensao da vıda cotıdıana na reflexão do Serviço Social é apresentada, na literatura brasileira, pelo trabalho de S. A. Barbosa Lima. Participação social no cotidiano. São Paulo, Cortez \& Moraes, 1979. 
o profissional, em sua prätica de campo, interfere, em graus diversos de intensidade, na vida das pessoas com quem trabalha, invadindo de certa forma sua privaticidade. Explicita-se, aí, a importância do compromisso social do Assistente Social, orientado no sentido de solidarizar-se com o projeto de vida do trabalhador ou de usar esse acesso à sua vida particular para objetivos que ihe são estranhos. Esta atuação é marcada pelo carāter pessoal da relação, na qual os sujeitos são tratados pelo Assistente Social como seres particulares. Sendo esta uma característica do exercício pro fissional, embora não the seja exclusiva, $\vec{e}$, muitas vezes, exacerbada na representação do agente técnico, fazendo com que a preocupação em apreender a singularidade dos indivíduos e a de sua situação de vida se faça segmentando-a de suas bases sociais. Os elementos mais gerais e comuns à situação de classe do trabalhador tendem a ser obscurecidos pela indivi dualização e pulverização dos casos, prevalecendo o "dito" de que cada caso é um caso.

Face às relações sociais vigentes, em que as pessoas são tratadas como peças anônimas da engrenagem de pro dução, a personificação de seu oposto -- isto é, do pessoal e do humanitário -- é, também, capitalizada pelo poder, assumin do um papel de relativa importância na consolidação de sua le gitimidade. Sendo o Assistente Social um técnico em relações humanas por excelência, essas caracterísicicas apontadas na prätica profissional são recuperadas pelos representantes do poder no sentido de interferência e controle de aspectos da vida cotidiana da classe trabalhadora, utilizando-se da media ção desse intelectual. Busca-se canalizar aspirações desses setores para sua satisfação através de canais institucionais, geridos pelos representantes do poder e detectar as tensões sociais a tempo de propor medidas preventivas para seu enquadramento. Essa ação controladora, no entanto, é esvanecida pe 10 discurso humanista e humanizador acoplado a esse tipo de 
intervenção, discurso esse mobilizado e incorporado pela prō pria burguesia e, ao mesmo tempo, sabotado na prätica pela subordinação da atividade profissional a um projeto de classe. Aquela representação contribui para inverter a prioridade dos elementos do projeto das classes dominantes para a sociedude, ou seja, a lógica da acumulação passa a ser vista ao reverso: a produção voltada, não para os imperativos de reprodução do capital, mas para a satisfação das necessidades humanas e sociais. Assim, o trabalho profissional passa a ser utilizado no sentido de propiciar uma face humana e pessoal às relações contratuais, desfigurando-as, a nível do discurso, de seu carāter de classe. Ao reduzi-las a relações individualizadas e naturais, passa o profissional a operar a partir de um corpo conceitual que busca harmonizar as contradições presentes na realidade, despojando a dinâmica social de sua historicidade. A teoria passa a equivaler à realidade idealizada, que, se adequada à racionalidade do capital, é insuficiente para orientar cientificamente a ação profissional no jogo das forças sociais, correndo o Assistente Social o perigo de tornar-se vítima da visão mistificadora que incorpora. Subjacente a esse suporte simbólico, encontra-se o aval à "normalidade" da sociedade do capital, acentuando-se apenas a necessida de de romper certas arestas que dificultam sua realização pro blemātica. A partir dessa perspectiva, as situações conflitivas e as desigualdades passam a ser vistas como "desvios" a serem contornados e controlados institucionalmente, segundo parâmetros técnicos. Os conflitos sociais não são negados, mas, o que é expressão da luta de classes, transforma-se em "problema social", matéria-prima da assistência. Segundo essa visão, os fatores tidos como problemāticos são deslocados da estrutura social para os próprios indivíduos e grupos conside rados como responsāveis pela sua ocorrência. Consequentemente, o que deve ser mudado são os häbitos, atitudes e comportamentos dos indivíduos, tendo em vista seu ajustamento social, contribuindo, assim, para remover "obstáculos" ao "crescimen- 
to econômico". Daí deriva uma visão estereotipada da classe trabalhadora, que inclui elementos como: população negligen te, carente de iniciativa, com baixo nível de consciência, ig norante, que necessita incorporar häbitos civilizados, que precisa ser orientada, etc. (41) Assim a visão do cliente pas sa a ser incorporada segundo a imagem difundida pela burguesia paxa a classe trabalhadora, alicerçada em um suporte simbölico que inclui elementos humanitärios e a mistica da moder nização. Nesse sentido, poder-se-ia afirmar que o Assistente Social è chamado a constituir-se no "moderno filantropo da era do capital". (42) Essa imagem do Assistente Social não é alheia ao Estado. Se ela tem suas raízes na origem confessional da profissão em suas íntimas relações com a necessidade de racionalização das atividades filantrópicas, pode ser enca rada, também, como uma extensão da imagem com que o Estado tende a se apresentar para o conjurıto da sociedade. 0 Estado aparece como o benfeitor, voltado precipuamente para o bem-es

(41) Anälise semelhante, referente à extensão rural e ao processo da modernização da agricultura, vem sendo efetuada por 0 . Queda. Ver, por exemp 1o, 0. Queda e J. C. Duarte. "Agricultura e acumnlação." Debate e Crítica n. 2, Sảo Paulo, Hucitec, jan-jun. 1974, p. 90-7; 0. Queda, et alii. Evolucão recente das culturas de arroz e fei ião no Brasil. Braș lia, Binagri, 1979. Ver, tambem, J. S. Martins. Capitalismo e tradicio-" nalismo, op. cit.

(42) "Á escolla humanitäria è a que lastima o lado mau das relações de produção atuais. Para tranquilidade de sua consciência esforça-se para coonestar o mais possivel os contrastes reais; deplora sinceramente as penalidades do proletariado e a desenfreada concorrência entre os burgue ses; aconselha aos operärios que sejam sobrios, trabalhem bem e tenham poucos filhos; recomenda aos burgueses que moderem seu ardor na esfera da produção... A escola filantrópica è a escola humanitäria aperfeiçoada. Nega a necessidade de antagonismo; quer converter todos os homens em bur gueses; quer realizar a teoria enquanto se distinga da prätica e não coñ tenha antagonismo. E evidente que na teoria é fácil fazer abstrações das contradições que se encontram a cada momento na realidade. Essa teoria equivaleria, então, à realidade idealizada. Por conseguinte, os filantro pos querem conservar as categorias que expressam as relações burguesas, porém sem o antagonismo que constitui a essência dessas categorias e que e inseparâvel delas; os filantropos acreditam que combatem a sério a prâa tira hirrmaca mac são mais burgueses do que ninguêm." K. Marx. La Mise ria..., op. cit., p. 109 . 
tar dos cidadãos, guardião da justiça e da paz social, deten tor de uma ética e de uma vontade supraclasses, representante dos interesses gerais da sociedade; o Estado tecnicamente armado para administrar os conflitos e problemas sociais, a ser viço do povo. O Serviço Social, ao ser incorporado no aparato de Estado, tende a reproduzir, em sua prática institucional, não sỏ o paternalismo autoritário estatal face à classe traba lhadora, mas também o discurso do Estado, expressão da ideolo gia dos governantes. Assim, a defasagem entre a representação humanitäria e modernizadora do Serviço Social e os efeitos so ciais objetivos da prätica profissional acompanha a aparente ambiguidade entre a figura do Estado do Bem-estar Social e os fundamentos histöricos da necessidade do Estado.

Este suporte simbölico e a agilização dos mecanismos de controle do trabalhador têm como pano de fundo a própria organização da produção, típica da grande indüstria capitalista. Os novos mëtodos de organização da produção e do trabalho são indissociāveis de um modo de viver, de pensar e sentir a vida, sendo que a obtenção de resultados efetivos, em um campo, está intimamente associada ao èxito no outro. A automatização do trabalho, a subordinação da atividade humana à máquina, enquanto capital fixo; a perda de controle do trabalhador sobre seu processo de trabalho, coordenado e gerido pelos representantes do capital; a incorporação dos avanços científicos à produção, como meio de potenciar o trabalho, am pliando o tempo de trabalho não pago do trabalhador, apropria do pela classe capitalista; a desqualificação progressiva do trabalho, reduzindo o trabalhador a mero vigilante de um conjunto de mäquinas, etc.-- todos esses fatores implicam mecanismos disciplinantes eficientes e de vigilância dos agentes de produção.

Mas a organização da produção não supõe apenas um controle do trabalhador no interior da fäbrica. Implica um novo tipo de socialização do trabalhador e de sua fam $\vec{\imath}$ - 
lia, que afeta todo o seu cotidiano, de modo a adaptā-lo ao novo modo de vida e aos mëtodos do trabalho industrial. O capital busca estabelecer meios de tutela e normatização da vida do trabalhador fora da óäbrica, invadindo sua vida privada. Procura não apenas conservar um certo equilíbrio psicofí sico do trabalhador, visto que não devem ser avariadas em demasia as peças de uma máquina coletiva de trabalho, mas ampliar a interferência moral e política por parte do capital sobre o conjunto da sua vida particular. Nesse sentido tem à sua disposição o aparato de Estado, além das pröprias iniciativas benemerentes levadas a efeito pela classe patronal. A $\vec{\imath}$, a coerção social deve ser habilmente articulada com a persuasão e o consenso, que dão a forma exterior ao uso intrinseco da força. Trata-se de canalizar esforços no sentido de que a classe trabalhadora interiorize as normas do novo modo de vida imposto pelo capital, minando suas iniciativas autônomas de organização enquanto classe. Busca-se fazer com que a vigi lância exterior possa ser acoplada à interiorização dos padrões dominantes, transformando, assim, o controle externo em um tipo de normatização de vida incorporada e proposta pelo pröprio trabalhador. (43) No entanto, por mais eficientes que sejam as medidas nessa direção, elas são rebatidas pela reali dade objetiva das condições de vida do proletariado, em que a

(43) Gramsci, analisando o fenômeno da racionalização do trabalho nos Estados Unidos, mostra que "os inquéritos dos industriais sobre a vida îtima dos operärios, os serviços de inspeção criados por algumas empresas para controlar a 'moralidade' dos operảrios, são necessidades dos no vos métodos de trabalho. Rir-se dessas iniciativas (se bem que tenhan fá lido) e ver nelas apenas manifestação do 'puritanismo' é negar qualquer possibilidade de compreender a importância, o significado e o alcance ob jetivo do fenômeno norte-americano, que è, também, o maior esforço coletivo até hoje verificado para criar, com inaudita rapidez e com una cons ciência de fim nunca vistos na histôria, um novo tipo de trabalhador $\overline{\mathrm{e}}$ de homem". Ao analisar as iniciativas "puritanas" dos industriais tipo Ford, acentua que: "'é certo que eles não se preocupavam com a "humanida$\mathrm{de}^{\prime}$, com a 'espiritualidade' do trabalhador, que é imediatamente arruina da. Essa 'humanidade' e essa 'espiritualidade' não podem senão realizar= se no mundo da produção e do trabalho, na criação produtiva; era máxima no artesãú e no demiurgo, quando a personalidade do trabalhador se refle 
vivência coletiva do processo de exploração aponta para a questionamento dos mecanismos controladores e para a desmisti ficação do discurso dominante sobre o trabalhador. E dentro desse panorama que pode ser compreendida a institucionaliza ção e a demanda do Serviço Social pela classe capitalista, co mo uma das tecnologias colocadas a serviço da reprodução da força de trabalho, do controle social e da difusão da ideologia dominante para a classe trabalhadora.

tia toda no objeto criado, quando era muito forte a ligação entre arte e trabalho. Mas, precisamente, contra este 'humanismo' luta o novo industrialismo. As iniciativas 'puritanas' têm apenas o fỉm de conservar, fora do trabalho, um certo equilíbrio psicofísico, que impeça o colapso psicológico do trabalhador, esmagado pelo novo método de produção. Este equilíbrio não pode ser senão exterior, mas poderá tornar-se interior se é proposto pelo próprio trabalhador e, não, imposto de fora, por uma nova forma de sociedade e por meios apropriados e originais..." e o autor vai alêm, afimando que: "as tentativas feitas por Ford de intervir, com um corpo de inspetores, na vida privada de seus dependentes e contro lar como gastavam seu salärio e como viviam, é indício dessas tendências ainda 'privadas' ou latentes, que podem se tornar, a certa altura, ideologia estatal..." A. Gramsci. Amerícanismo e Fordismo." In: Obras es co-. Ihidas, v. II. Lisboa, Estampa, 1974, p. 166, 168, 169, respectrvamente. 
5. LEGITIMAÇÃO E CRISE DO SERVIÇO SOCIAL

5.1. Problematização do Tema

Este capitulo, de caräter conclusivo, pretende retomar, aprofundar e complementar elementos jä explicitados na anâlise do significado social da profissão no processo de reprodução das relações sociais, tendo em vista problematizar a legitimação e crise do Serviço Social, na sociedade brasileira, nas três ültimas dëcadas.

Se a reflexão anterior procurou detectar algu mas características da intervenção do Assistente Social e elü cidar o que justifica, historicamente, a necessidade do Servi ço Sccial na sociedade capitalista, busca-se agora, avançar a reflexão numa dupla direção. Em primeiro lugar, dar um contor no histórico-conjuntural mais preciso às considerações feitas que permitam apreender certas peculiaridades da intervenção profissional do Assistente Social, nos marcos da crise e consolidação do poder burguês, expresso na constituição do que Florestan Fernandes denomina "Estado Autocrätico-Burguês". 
(1) Em segundo lugar, privilegiar as respostas que vêm sendo dadas pelo profissional às novas características da demanda da classe capitalista no enfrentamento da "questão social", matizada pelas determinações peculiares do capitalismo na periferia. Essas respostas, não sendo unívocas, orientam-se seja no sentido de atualização da instituição Serviço Social - de seu discurso e de sua prätica - face as novas preocupa ções das instâncias mandatārias; seja no sentido de buscar novas fontes de legitimidade do exercício profissional junto aos setores sociais que constituem o alvo da intervenção têcnica, reorientando a direção social desse fazer para o hor zonte das classes trabalhadoras. Esta alternativa supc̃e uma ruptura com os traços de origem conservadora dessa institui ção, na busca de conformar uma prática de nova natureza para - Serviço Social.

A análise estā, pois, voltada para apreender as mudanças verificadas na instituição, como respostas às exigên cias e desafios que lhe são apresentados pela própria realida de face a nova correlação de forças dos grupos e classes sociais, que se impõe numa conjuntura de aprofundamento do cap $\underline{i}$ talismo monopolista na periferia dos centros hegemônicos mundiais.

(1) F. Fernandes. A Revolução Burguesa no Brasil. Ensaio de Interpretaçao Sociolögica. Rio de Janeîro, Zahar, 1975; F. Fernandes. Apontamentos sobre a "Teoria do Autoritarismo", São Paulo, Hucitec, 1979; F. Fernandes. Brasil: Em Combasso de Esvera. Peauenos Escritos Políticos, São Paulo, Hucitec, 1980. Deve-se esclarecer que, enbora a reflexeo propos ta esteja referenciada à sociedade brasileira, especialmente após 1964, não se pretende elaborar uma anālise exaustiva da conjuntura do pe ríodo. O texto deverá manter un caráter mais teórico-metodológico do que propriamente histórico-conjuntural, embora tenha sido indispensävel uma circunscrição mais definida da reflexāo no tempo e espaço, dada a impossibilidade de se pensar o tema universalmente. 
Sendo a análise balizada por esta premissa fun damental, deve ser aliada ao outro lado da questão: o comportamento assumido pelos profissionais face à demanda, o qual não é meramente reflexo. Em outros terinos: os condicionantes histórico-conjunturais são mediatizados pelas características que, historicamente assumidas, dão um perfil peculiar a este exercício profissional no mercado de trabalho e ainda, pela maneira como os seus agentes sociais se posicionam, como inte lectuais, face ao confronto das classes fundamentais nesse mo mento histórico da sociedade brasileira.

Sendo a prática profissional historicamente de terminada, as respostas dadas pelos agentes profissionais tam bëm condicionam a configuração dessa instituição, dentro dos limites estabelecidos pela própria realidade. Destacar este movimento da prâtica profissional, como resultante da história, mas também como produto criado pelos intelectuais que a ela se dedicam, é o centro da diretriz analitica deste capítu 10. Porém, se a apreensão desse movimento deve ser garantida, a ênfase da reflexão estarā em acentuar como esses intelectuais vêm se posicionando frente às exigências com que se defrontam numa conjuntura peculiar, marcada pelo autoritarismo.

Considerando que o projeto profissional não $\bar{e}$ desvinculado de um projeto de classe, como os Assistentes So ciais vêm fazendo uso da relativa autonomia que dispõem no exercício de suas funções intelectuais, nesse momento históri co, para conformar repostas repetitivas e/ou inovadoras às de mandas no enfrentamento da "questão social"?

No encaminhamento dessa indagação, considerase a prática profissional como uma prätica em processo, em constante mudança, fato este derivado fundamentalmente das mo dificações nas formas de expressão e do aprofundamento das contradições sociais que peculiarizam o desenvolvimento da sociedade brasileira. A medida que novas situações históricas se apresentam, a prática profissional, como componente das 
mesmas, tambēm è obrigada a se redefinir. Estas constantes redefinições, que passañ pelas elaborações teórico-práticas de seus agentes especializados, configuram uma "passagem de prătica", mais que uma prática critalizada, o que muitas vezes é classificado sob a rubrica de uma crise profissional. Esta crise não é mais que a expressão, na consciência de seus agentes, da temporalidade dessas práticas, da necessidade de redefinições. Estas podem ser encaradas na perspectiva de mera atualização, modernização da atividade profissional segundo parâmetros de racionalidade e eficiência, ou como ruptura com o compromisso social historicamente estabelecido, com os representantes do capital, buscando reorientar o potencial des sa prática na perspectiva das classes sociais subalternas, o que obriga o profissional a repensar seu fazer de maneira antagōnica à definição oficial. E, aí, segundo Brandão, que se expressa para o profissional um dilema de grande dimensão,que não é apenas um dilema profissional, mas essencialmente político. Trata-se da crise vivenciada pelo profissional media dor, comprometido com a população numa dimensão de seus reais interesses de classe. Ora, os profissionais são constituídos para serem agentes mediadores dos interesses do capital, que $\ddot{e}$ quem tem o poder de produzir e legitimar tais serviços, de aprovar os estatutos profissionais, de remunerar seus agentes. E quem os constitui, os paga, determina sua parcela de poder, define e redefine sua prática. Este é, estruturalmen te, o papel dos diversos profissionais na sociedade capitalis ta. A luta pela identidade profissional dos intelectuais que buscam conferir uma nova dimensão socią à sua prática supõe um diıema de definição que não está diretamente colocado para quem os contrata, mas sim para a categoria profissional: a

(2) C.R. Brandão. "A Prática Social e a Prática Profissional". Pales tra pronunciada no Seminário Regional de ABESS - Associação Brasileira = de Ensino en Serviço Social - Região Sul II. São Paulo, 12 de maio de 1981. O desenvolvimento da noção de crise profissional se apoia no conteūdo da referida exposição. 
questão política da definição dessa prática que subordina a questão propriamente profissional. Assim, não é possíve1 "cor rigir" uma questão eminentemente política, com uma mera corre ção técnico-profissional, não sendo suficiente modernizar o aparato profissional para resolver um problema que não ẻ mera mente profissional.

Essa direção da análise supõe aṇreender as diversas manifestações da crise profissional, como expressão da crise da própria sociedade (̧) , da realização tensa do capita lismo na periferia.

Porém, pensar esta crise no Serviço Social implica em assimilar as peculiaridades dessa profissão, que desenham um perfil característico à vivência dessa crise pelos seus agentes. Essas características particulares serão coloca das em relevo no desenvolvimento do tema, cabendo ressaltar, de imediato, alguns elementos básicos que explicam a articula. ção proposta entrie crise e legitimação.

Conforme o jă explicitado, a fonte de legitima ção da demarida do Serviço Social não tem sido derivada daqueles setores sociais que são o alvo da intervenção profissional mas, sim, dos segmentos que controlam as organizações em que atua o Assistente Social e através das quais buscam sedimentar sua influência sobre o conjunto da sociedade.

A prática profissional è, pois, polarizada por projetos sociais diferentes, dos setores mandatários e da população alvo. Esta tensão tem sido "resolvida" na trajetōria histôrica da instituição Serviço Social no sentido da adesão objetiva de seus agentes, conscionte ou não, aos interesses sociais das classes dominantes, traduzidos na direção imprimí

(3) Refere-se, aqui, a una noção ampla de crise "considerando-se a dominţ̧ão burguesa, em suas conexöes diretas com a reprodução da ordem burguesa e sua desagregação". F. Fernandes. Apontamentos sobre a "Teoria do Autoritarismo", op. cit., pág. 12. 
da à prätica e no modo de pensar que a informa. Isso vem mar cando o Serviço Social com o selo da imposição. Este caráter impositivo, encontra-se em tensão permanente com um dos requi sitos dessa ação que supõe obter a adesão dos clientes a seus propósitos e a seus fundamentos. Obter, permanentemente essa adesão, mesmo quando ela contraria os interesses objetivos da população a quem se dirige, "e uma condição vital para a conti nuidade da pröpria instituição. Supõe traduzir os serviços prestados de modo que fique explícito para quem os recebe a sua necessidade, mobilizando o seu consentimento para a inter venção técnica. Muitas vezes, a coerção deve ser engenhosamen te articulada à persuasão, veiculada sob a forma de um discur so que propõe respeito à livre iniciativa do "cliente".

Porēm, aí, não se esgota a questão da legitima ção do exercício profissional. Se do ponto de vista de uma prática identificada com as perspectivas da população, o seu reconhecimento: $\bar{e}$ um dos fulcros principais do problema, ele tem adquirido um menor relevo no evolver dessa instituição. Os esforços têm se concentrado no sentido de garantir uma de monstração constante da indispensabilidade de seus serviços àqueles de quem tem emanado o poder de delegação de autoridade ao profissional, de requisitar e remunerar o seu trabalho, fornecendo-1he os meios necessärios para agir. Isto implica numa atualização permanente da instituição Serviço Social, fa ce aos problemas e preocupações que agitam as classes dominan tes, frente às pressões e ameaças, efetivas ou potenciais, que representam para elas o aprofundamento da "questão social". Derivam, daí, não apenas a necessidade de atenuar os proble mas sociais, mas de propor medidas controladoras, abertamente repressivas e/ou atenuadas por um respaldo técnico-científico.

A renovação das bases de legitimação do Servi ço Social junto à classe capitalista e ao Estado burguês exí ge que a instituição e seus agentes renovem, permanentemente, as manifestações de sua prōpria adesão aos propōsitos de clas 
se, corporificados nas organizações institucionais a que os Assistentes Sociais se encontram objetivamente vinculados.Tal exigência torna-se mais aguda numa profissão não "libera1", com um baixo "status" diante de profissões congêneres, que não evoca cientificidade e saber, marcada por sua origem no benevolato, e pelo caráter basicamente feminino da profissão.

o carāter difuso das tarefas que o Assistente Social executa, dificeis de serem precisadas e definidas, se converte em mais um fator reforçador da necessidade de uma constante "interpretação de suas funções", tanto junto às ins tâncias mandatárias, convencendo-as da rentabilidade e eficăcia do empreendimento, como junto à população que recebe os seus serviços. Isso não exclui a exigência do pröprio profissional convencer-se da indispensabilidade e elevada utilidade social dos serviços a que se dedica, cujos resultados näo são facilmente apreendidos e demonstráveis. Isto supõe que o pro fissional incorpore uma carga simbölica suficientemente sỏlida, amplamente favorecida pelas marcas cristãs e humanitárias, que the permita convencer-se da "superioridade" de seu trabalho, face a outras profissões predominantemente técnicas: ai o passado missionärio e o componente vocacional são ricos ingredientes que reforçam o caräter "especial" da profissão na representação de seus agentes.

Crise e legitimação do Serviço Social implicam-se e realimentam-se mutuamente. Para o profissional que vivencia a "crise" profissional apenas como imperativo de modernização do aparato tấcnico-profissional, sem colocar em questão as bases politicas da legitimação de seu fazer, aquela se resolve facilmente no aprimoramento técnico da institui ção em função das exigências do processo de acumulação e da modernização do Estado. Implica, necessariamente, em efetuar mudanças teörico-prāticas no Serviço Social, porém mudanças acopladas à evolução das estratégias do poder no controle da sociedade civil e, em especial, da classe trabalhadora, reno- 
vando os laços de aliança entre os agentes profissionais e as classes que os constituiram, atuando eficazmente para o forta lecimento das organizações nas quais atuam.

A crise/legitimação aparece com um quadro qua litativamente diferenciado para aqueles que buscam situar o Serviço Social nos rumos da histōria. Aí, crise e legitimação incorporam as contradições bäsicas da ordem burguesa. São a expressão, a nível da profissão, de uma questão que não é co locada prioritariamente pelo profissional, mas pela dinâmica da realidade e por ele assumida: a da criação de uma contrahegemonia no bôjo das relações sociais fundamentais da socie dade. Crise/legitimação supõem ruptura profunda com o modo de pensar, de dirigir, de educar, daqueles que vivem no patamar superior da sociedade. Implica em ultrapassar, atravēs da prä tica coletiva identificada com os setores subalternos e da compreensão da sociedade comprometida com o desvendamento e explicação de suas contradições, a consciência ambiggua e hete rōclita do prōprio intelectual, de modo a se tornar, efetivamente, um especialista e um politico, is to $\overrightarrow{\mathrm{e}}$, um dirigente que seja expressão dos interesses dos setores majoritārios da po pulação por ela requerido e reconhecido.

O desenvolvimento da problematização proposta encaminha-se no sentido de ressaltar como vem se delineando a "questão social" nos quadros do capitalismo monopolista, destacando aí, o Estado em suas relações com as classes so ciais, como pilar que assegura a expansão da acumulação nos marcos da rearticulação do poder burguês. Nesse contexto serão acentuadas as novas determinações da política assistencial e suas derivações para a prätica profissional.

Em seguida busca-se apreender as característi cas das funções intelectuais desempenhadas pelo Assistente Social procurando ressaltar alguns traços específicos desse profissional que condicionam e mediatizam o exercício de suas 
atividades intelectuais. Este $\bar{e}$ o fio da anālise que apresenta o Assistente Social como um profissional cuja demanda, an tes de ser técnica, é política, por excelência.

A discussão das respostas dadas pela categoria profissional à nova correlação de forças que se instaura na conjuntura de meados da década de sessenta, serâ efetuada considerando-se a crise profissional na dupla qualificação an teriormente referida. Essa reflexão passa pela anâlise da herança conservadora do Serviço Social, sua atualização e as tentativas de ruptura com as marcas de origem. Ressaltam-se os limites e potencialidades da profissão para cimentar rumos alternativos à prätica de ação controladora da vida cotidiana da população trabalhadora.

\subsection{A "Questão Social" no Capitalismo Monopolista}

A preocupação estã voltada para apreender as novas determinações da "questão social" nos marcos da consolí dação do capitalismo monopolista na sociedade brasileira e da constituição do Estado "autocrătico-burguês" e as derivações decorrentes para a assistência social. Estes são tidos como prë-requisitos para se compreender o significado das novas demandas que esta conjuntura apresenta aos Assistentes Sociais. A anālise deverā ressaltar o carāter do Estado em suas relações com as classes sociais, especialmente as implicações do novo padrão de dominação para as classes trabalhadoras. (4)

(4) A räpida retomada de alguns aspectos considerados bâsicos da con juntura assinalada está basicamente calcada na interpretação de F. Fernandes expressa especialmente em: A Revolução Burguesa no Brasil. Ensaios de Interpretação Sociológica, op. cit., e Apontantentos sobre "Teoria do Autoritarismo". Foi, no entanto, consultada a seguinte 1iteratura: F. Fernandes. Capitalismo Dependente e Classes Sociais na America Latina. Rio de Janeiro, Zahar, 3a. ed., 1981; F.H. Cardoso. 0 Modelo Politico Brasileiro e outros Ensaios. São Paulo, Difel, 1973. F.H. Cardoso. Autoritarismo e Democratizaçao. Rio de Janeiro, Paz e Terra, 3a. ed., 1975; P. Singer. A Crise do Milagre. Interpretacão Crítica da Economia Brasileira. Rio de Jane1ro, Paz e Terra, 3a. ed., 1977; P. Singer 
A presença das grandes corporaçồes, operando diretamente ou por meio de filiais, no cenärio da vida brasileira, contribui, até à segunda guerra, para dinamizar a economia competitiva dependente, ao mesmo tempo em que concorrem para a expansão monopolista das economias centrais, atravês do excedente acumulado em suas operações no país. E a partir da década de cinquenta, que a economia brasileira se incorpo ra a esse padrão de desenvolvimento, como um de seus polos di nâmicos da periferia dos núcleos hegemônicos centrais. Tal in tegração adquire novo alento com os governos militares, quando o capital monopolista passa a contar não apenas com o espa ço econômico que conseguira abrir na economia, mas com o respaldo de uma política econômica capaz de articular a ação governamental aos interesses dos grandes empresärios.

E nessa transição do capitalismo competitivo ao padrão monopólico de acumulação, viabilizado pelo grau de avanço relativo da economia do país, capaz de absorver as prâa ticas industriais, financeiras e de consumo requeridas pela concentração e centralização do capital, que se verifica o que Fernandes qualifica de "crise e consolidação do poder bur

et alii. São Paulo, 1975: Crescimento e Pobreza. São Paulo, Loyola,1976; P. Singer e V.C. Brandt. São Paulo: O Povo em Movinento. Petrópolis, Vozes/Cebrap, 1980; C. Furtado. O Bras ll Pos-Milagre. Río de Janeiro, Paz e Terra; 1981; O. Ianni. Estado e Planejamento Econômico no Brasil (1930 -1970). Rio de Janeiro, Civilização Brasileira, 1979; 0. Iansi. Colapso do Populismo no Brasil. Rio de Janeiro, Civilização Brasileira, To68; 0. Ianni. Di tadura e Agricultura. Rio de Janeiro, Civilização Brasileira, 1979; G. Mântega e M. Morais. "Tendências Recentes do Capitalismo Brasileiro". Contraponto n $^{\circ} 3$, Ano III, Rio de Janeiro, Centro de Estu dos Noel Nutells, set. 1978, p. 59-67; F. Weffort et alii. "A Crise Po= lítica e Institucional". Revista de Culltura Contemporânea, $n^{\circ} 2$, Ano I, São Paulo, Cedec, jan. 1979, p. 47-61; J.M.C. de Mello e L.G. de Mello Beluzzo. "Reflexōes sobre a Crise Atual". Escrita Ensaio, n' 2, Ano I, 1977, p. 16-27. 
guês e da dominação burguesa" $(\underline{5})$, estreitamente artículadas as condições impostas pelo "imperialismo total" (6).

Os pontos de clivagem dessa crise derivavam,em primeiro lugar, de pressões oriundas do capitalismo monopolis ta mundial, que exigia condiçöes precisas de "desenvolvimento com segurança", is to é, de garantias econômico-sociais e polí ticas ao capital estrangeiro e ao crescimento de suas empresas aqui instaladas. Em segundo lugar, haviam as pressões in ternas de dupla derivação. De um lado, procedentes do radicalismo burguês, e dos trabalhadores, que, se não chegavam a ameaçar as bases do poder burguês, eram fontes de seu desgaste, restringindo a eficácia de sua dominação. De outro 1ado, as proporções crescentes assumidas pela intervenção do Estado na economia, que ao adquirir uma força administrativa e empre sarial expressiva, torna-se "inquietadora" para a iniciativa privada nacional e externa. O poder burguês se esvaziaria se perdesse o monopólio do poder estatal.

(5) F. Fernandes. A Revolução.... op. cit.

(6) A noção de imperialísmo total expressa, para o autor citado, un novo tipo de dominação externa que emerge com a expansão recente das grandes empresas corporativas na América Latina, e que trazem consigo lm novo estilo de organização, de produção de "marketing", com novos padrōes de planejamento, propaganda, concorrência e controle interno das economias dependentes pelos interesses externos. Representando o capitalismo monopolista, absorvem posições de liderança antes ocupados por indüstrias e empresärios nativos. "O traço específico do imperialismo total consiste no fato que ele organiza a dominação externa a partir de dentro e em todos os níveis da ordem social, desde o controle da natalidade, a comrnicação de massa, o consumo de massa, atê a educação, a transposição macị ça de tecnologia ou de instituições sociais, a modernização da infra $\overline{\mathrm{e}}$ da superestrutura, os expedientes financeiros ou de capital, o eixo vital da política nacional etc. F. Fernandes. Capitalismo Dependente e Classes Sociais na América Latina, op. cit., cap. 1. "Padroes de Dominaçăo Externa na Amērica Latina", p. 18. 
Para fazer face a tais pressões a burguesia se vê impelida a articular-se internamente, sobrepujando os seus interesses particularistas em conflito em favor da solidifica ção de seus laços de solidariedade. Mobiliza para tanto interesses comuns calcados na defesa da iniciativa e propriedade privadas, da ordem e do monopólio do poder pela classe. Faziase necessärio tanto uma integração horizontal, em escala nacional, dos interesses das classes burguesas, como a possibilidade de universalizá-los para toda a sociedade, seja nas relaçōes diretas entre as classes, seja atravês do Estado. (7)

Essa crise tem, como pano de fundo, a exigên cia de adaptação da burguesia à industrialização intensiva e aos novos ritmos econômico-sociais, transferidos de fora para a sociedade brasileira. 0 imobilismo econômico poderia ter desdobramentos a longo prazo, seja na deterioração da dominação burguesa ou no seu deslocamento pela iniciativa privada estrangeira. A burguesia deveria, portanto, reajustar seu padrão de dominação, de modo a fortalecer-se, como garantia de sua prôpria sobrevivência e auto afirmação de seu "status" como burguesia "nacional" nas relações internacionais com o sistema capitalista, embora receptiva às irradiações externas.

A crise desemboca numa contra-revolução defensiva, embora agressiva, da qual a burguesia sai fortalecida, em condições favorāveis para estreitar seus laços com o capitalismo financeiro internacional, reprimir, pela violência, toda e qualquer pressão dentro ou fora da ordem, e, transformar o Estado em instrumento exclusivo do poder burguês, nos planos econômico, político e social. Passa a dispor de maior

(7) Na luta de sobrevivência do capitalismo contra o socialismo, as burguesias nativas contam com o apoio das naçōes hegemônicas, interessa das em fortalecê-las à medida que constituem o suporte da expansão imperialista na periferia, sob o capitalismo monopolista. Elas contam com o reforço externo para modernizar as formas de socialização, opressão e repressão inerentes à dominação burguesa. 
flexibilidade para fixar uma política econômica destinada a acelerar a acumulação e favorecer a modernização tecnológica.

o traço peculiar dessa transição do capitalis mo monopolista nas sociedades dependentes é que elá näo ocorre segundo o modelo clāssico de revolução nacional e đemocracia burguesa. Esta aspiração, embora presente nas "ilusões" da burguesia, -- ou seja, de que as forças acumuladas no capi talismo competitivo seriam suficientes para desencadear um mo vimento interno autônomo e conferir à burguesia uma sólida orientação democrático-nacionalista -- não encontra suporte em burguesias frágeis diante da influência externa e impotentes diante da luta entre interesses particularistas de suas frações. Assim o visado não era o desenvolvimento nacional autônomo, mas a autonomia das classes e estratos burgueses na sociedade e a possibilidade de consolidar a transformação capitalista moncpolista, indissociāvel, naquelas circunstâncias, da manutenção da dependência e do desenvolvimento desí gual interno. Esta passagem não coloca as classes dominantes diante do problema da democracia burguesa, mas da ordem bur guesa. A referida transição leva a dissociação entre desenvo 1 vimento econômico e desenvolvimento político. Ou seja, instau ra um padrão racional e modernizador de acumulação, ao mesmo tempo em que transforma o poder estatal em uma "autocracia burguesa" ou em uma "versão tecnocrätica da democracia restri ta".

A resolução da crise do poder burguês, passa pela esfera política, atravês da reorganização do Estado, colocado a serviço da iniciativa privada, favorecendo a adequação do espaço econômico e político aos requisitos do capitalismo monopolista. O Estado torna-se o eixo político da recom posição do poder burguês. A dominação burguesa ressurge com uma composição de poder heterogênea, de base nacional e inter nacional, congregando conservadores e liberais, ou seja, a he gemonia burguesa alcançada e "uma hegemonia agregada, de sim 
ples articulação mecânica de interesses de classe" (ㅇ), mas que lhe permite superar momentaneamente sua impotência histórica.

Toda a sociedade passa a ser vazada por uma rẹ de de relações autoritárias, incorporadas às instituições, ideologias e aos processos sociais, tendendo a exarcebar-se como uma forma de auto-defesa das classes dominantes. (9)

Coube ao Estado, enquanto nücleo do poder bur guês, reduzir e comprimir o espaço político e jurídico de to das as classes que se opusessem ao novo padrão de dominação, sendo o proletariado e as massas trabalhadoras o alvo privile giado da agressão auto-defensiva da burguesia. As pressões dai oriundas tenderam a ser deslocadas para "fora da ordem", como estratagema para legitimar e impor o poder. Um conflito intenso de classes, encoberto e reprimido, marca sua presen ça. Os comportamentos coletivos de auto-defesa dos trabalhado res foram deslocados para a esfera de segurança nacional. 0 elemento peculiar que aí aparece não é a violência institucio nalizada, mas uma concepção de segurança cimentada na noção de guerra permanente de umas classes contra as outras, assumi da pelo Estado Nacional.

(8) F. Fermandes. A Revolução..., op. cit., p. 335.

(9) "Nesse contexto historico-social, a dominação burguesa não è sỏ força sócio-econômica espontânea e una força política regulativa. Ela po lariza politicamente toda a rede de ação auto-defensiva, percorrida pelas instituições ligadas ao poder burguês, da Empresa ao Estado, dando origem a una formidavel superestrutura de opressăo e bloqueio, a qual converte reativamente a propria dominação burguesa na única fonte de po der político legítimo. Mero reflexo das relaçôes materiais de produçáo ela se insere, como estrutura de dominação, no âmago mesmo dessas relações, inibindo ou reorientando, espontânea ou institucionalmente, os pro cessos econômicos, sociais, e políticos por meio dos quais as demais class ses ou quase classes se defrontam com a dominação burguesa; F. Fernandes "O Modelo Autocrätico Burguês de Transformação Capitalista" In: A Revolução..., op. cit., p. 302-303. 
Se é na consoliãação do capitalismo monopolis ta que a burguesia alcança sua plenitude de poder, mantidos e agravadas as desigualdades econômico-políticas prē existentes, não ê apenas a burguesia que se recompõe. 0 proletariado adquire novo peso político e nova força social dentro da sociedade, ao mesmo tempo em que são fortalecidas as condições objetivamente favorâveis à disseminação dos conflitos de clas se e da organização política dos trabalhadores, temporariamen te bloqueadas de emergirem na superfície da sociedade.

Em síntese, o aprofundamento do padrão monopolista da organização econômica implicou uma reordenação da dominação burguesa e, consequentemente, das relações dessa classe com as demais, com o Estado, as grandes corporações e as nações centrais, cujos laços foram estreitados. Esse processo è acompanhado de uma radicalização do poder burguês,por intermëdio do "Estado Autocrätico-Burguês", que é fortalecido, concentrando a ação reguladora das relações sociais e a capacidade de gerir a economia. Torna-se a retaguarda necessária à iniciativa privada na dinamização da acumulação capitalista monopolista. Reforça-se o primado da estabilidade política como condição imposta externamente e assumida pela burguesia para a dinamização do desenvolvimento capitalista à base das grandes corporações estatais, privadas, nacionais ou estran geiras. Isso implicou, como diretriz, da exclusão das massas populares e do proletariado das negociações do poder, conceb $\underline{i}$ do como "inimigo principal" da nova composição de forças que detẻm o controle do Estado. Acentuam-se os mecanismos repressivos e de disciplinarização das relações de classe, como ga rantia do poder e da elevação dos níveis de produtividade do 
trabalho que passam a ser requeridos na grande indústria e em setores estratëgicos da agricultura. (10)

Assim explicita-se uma nova correlação de for ças mais favorävel às necessidades decorrentes do processo de aprofundamento capitalista nacional e internacional.'Ou seja, o novo modelo político que se impõe tem em vista a adequação do poder de Estado às novas necessidades da acumulação de modo a fortalecer a grande unidade de produção. Visto de outro ângulo, significa que a incorporação subordinada de interes ses das classes populares, verificada durante o período "popu 1 ista", torna-se secundāria face à nova correlação de forças e à base social de apoio ao governo central. Mais ainda, tra tava-se de necessidade prêvia de desarticulação dos instrumen tos de defesa dos trabalhadores para impor a radicalização do modelo de desenvolvimento econômico necessário ao novo patamar em que se situava internamente o aprofundamento do capita lismo e sua inserção na divisão internacional do trabalho. E ao fazer face a essas exigências que o Estado assume tanto funções repressivas no plano social, como modernizadoras no plano administrativo. (11) Ganha relevo a política de subsí dio ao grande capital, ao mesmo tempo em que tornam-se dominantes no aparelho de Estado os representantes da aliança en tre as forças armadas e a tecnocracia expressando os interesses daqueles setores do capital. Em substituição à ideologia "desenvolvimentista" impõe-se a ideologia da "modernização",

(10) "Com o golpe se instala uma ditadura a serviço do capital mono polis ta. Não só a aparelho de Estado, mas toda a vida econômica, políti= ca e cultural do país passou a ser amplamente determinada pela política de acumulação capitalis ta acelerada, daí o caráter agressivo e repressivo, em termos econômicos e políticos, da política econômíca estatal.Tratavase por um lado de expropriar o maximo o proletariado industrial e agríco $1 \mathrm{a}$, alêm de certos setores da classe média e do campesinato; e, por outrōo lado, tratava-se de abrir as portas do país a livre ação do capital monopolista estrangeiro." 0. Ianni. Ditadura e Agricultura, op. cit., p. 17.

(11) F.H. Cardoso. O Modelo Político Brasileiro e outros Ensaios. op. cit., p. E ilus trativa dessa modemização adminis trativa o Decreto Leì 200 , de 1967, que centraliza e unifica a administração federal. 
(12) de orientação pragmática e tecnocrática que, a partir de critërios de racionalidade crescente justifica um processo de super-concentração do poder estatal e acentuada burocratiza ção.

Sendo estes os contornos gerais da questão so cial nos quadros do capitalismo monopolista, resta acentuar algumas dimensões que a especificam, tanto a nível da situa ção de vida dos trabalhadores e das novas formas mobilizadas pela burguesia para o seu enfrentamento.

Em decorrência do novo équilíbrio de forças, verifica-se uma mudança significativa nas relações de trabatho (13) expressando-se atravēs das políticas salariais e sin dical, que traduzem um aumento do nível de exploração da clas se operária. O arrocho salarial é complementado tanto pela li. quidação de "direitos" jā conquistados como greve, e estabilidade, e pela desarticulação da estrutura sindical e partidá ria. Essas medidas viabilizam um aumento da taxa de explora ção do trabalho, através da ampliação da jornada de trabalho, da institucionalização das horas extras, do reforço da disciplina industrial, da intensificação do rítmo de trabalho, etc., tendo como contrapartida uma elevação da produtividade dentro de um clima de aparente ordem e "paz social".

A consequência da implantação das novas estratëgias de desenvolvimento, altamente concentradoras de renda e de capital é a queda do padrão de vida dos assalariados, que se expressa, entre outros fatores, no agravamento da des nutrição, de doenças infecciosas, no aumento das taxas de mor talidade infantil, dos acidentes de trabalho. (14) Em sintese,

(12) Ver 0. Ianni. O Colapso do Populismo no Brasil, op. cit., esp. Cap. IX "A Ideologia dos Governantes", p. 187-198.

(13) P. Singer. A Crise do Milagre. Intexpretação Crítica da Economia Brasileira, op. cit.. Ver, especialmente, Cap. II "A Economia Brasi1eira Depois de 1964", p. 77-98. cit..

(14) Ver: P. Singer et alii. São Paulo : Crescimento e Pobreza, op. 
verifica-se a ampliação da misēria absoluta e relativa de grande parcela da população trabalhadora, consubstanciando um processo crescente de dilapidação da força de trabalho coletí va. (15)

Face a desarticulação dos organismos politicoreivindicatörias da classe trabalhadora, de sua momentânea ex clusão da arena política e, frente à manutenção de uma polítí ca salarial comprimida -- requisitos da solificação da domina ção burguesa e da expansão capitalista -- a questão social passa a ser tratada através da já conhecida articulação entre repressão $e$ assistência, como condição de preservação da "paz armada" imposta pelo poder.

Como substitutivo do esvaziamento dos canais de participação política dos trabalhadores são intensificados os programas de cunho assistencial, (16) centralizados e regu lados pelo Estado e subordinados às diretrizes políticas de garantia da estabilidade social e de reforço à expansão capitalista. Em outros termos, a nova peculiaridade no enfrenta mento da questão social, no que concerne a assistência, é que ela passa a ser organizada de modo a atender um duplo requisito: favorecer a acumulação de capital pela iniciativa privada $e$ subordinar-se aos preceitos da segurança nacional.

De um 1ado, os programas assistenciais são mo bilizados pelo Estado como contraponto ao pêso político do proletariado e demais trabalhadores e a sua capacidade depres

(15) Dados do DIEESE demonstram que em 1964 o trabalhador, para alimentar uma familia de 4 pessoas, deveria trabalhar $262 \mathrm{~h} /$ mês e em 1976 este tempo aumenta para $546 \mathrm{~h}$ e $33 \mathrm{~min} / \mathrm{mês}$. Por outro lado, a produtivida de do trabalho cresce de fev. de 1964 a maio de $1976 \mathrm{em} 69 \%$ enquanto o salário mínimo real cai, no mesmo período em $41 \%$. Cf R. Coutinho. "Sobreviver para Trabalhar: Salário e Alimentação do Trabalhador Brasilei ro" Caderno do CEAS, n० 48, mar-abr, 1977. Salvador, Centro de Estudos̄ e A.çāo Social, p.

(16) Emergem nesse período, programas governamentais dentro de uma retórica de atenção às condições de vida do trabalhador, tais como: Pro nam, Furural, BNH e as Cooperativas Habitacionais, reestrutura-se a Pre vidência, surge o FGTS, PIS, PASEP, etc. 
são, experimentada no bojo da crise do poder burguês. Buscase, atravês deles, neutralizar manifestações de oposição, re crutar um apoio, pelo menos passivo ao regime, despolitizar organizações trabalhistas na tentativa de priorizar o traba 1ho assistencial sobre a luta político-reivindicativa. Assim, a política assistencial é irradiada até os sindicatos. Tratase da utilização da assistência como um meio de regular o con flito social em nome da ordem pública e da segurança da Nação.

As medidas assistenciais ingressam como um dos componentes da rede de relações autoritârias imprimidas à so ciedade, passando a articular-se às estratégias das relações do Estado com as classes trabalhadoras, como uma das áreas instrumentais do intervencionismo crescente do Estado na sociedade civil.

De outro lado, se o Estado se reserva o poder de regular tais políticas, orienta-se, tambëm, no sentido de favorecer a participação da iniciativa privada na ärea da prestação de serviços sociais, como campo de investimento do capital ou meio de obtenção de vantagens fiscais, fazendo com que a qualidade dos serviços seja subordinada aos requisitos de rentabilidade das empresas que atuam no campo. (17) A isto se acresce uma outra particularidade: esses serviços devem ser financiados, total ou parcialmente, pelos pröprios benefi ciärios. Na lógica que preside a estruturação dos serviços so ciais não ingressa qualquer componente distributivista. Ao conträrio, não se trata de distribuir, mas de construir, de

(17) São amplamente conhecidos, por exerrplo, os "Convênios" na ärea de prestação dos serviços de saủde, acarretando a "industrialização" dos serviços médicos. Os estudos sobre a política habitacional são, também, ilustrativos. 
acrescentar o capital investido, ampliando, consequentemente, as desigualdades sociais. (18)

Alguns desses "benefícios" sociais, como aqueles que se enquadram no campo do seguro social são, ainda, utilizados para o estabelecimento de uma poupança forçada, impingida pelo Estado, aos trabalhadores assalariados. Esta poupança, sendo gerida pelo Estado, tende a ser repassada aos capitalistas privados, favorecendo a reprodução do capital no conjunto da economia. Mediante deduções salariais compulsórias o trabalhador se vê compelido a reduzir satisfação de ne cessidades bâsicas atuais, em função de garantir possíveis benefícios futuros e a abrir mão da capacidade de decidir seu próprio consumo, em cuja esfera o Estado passa a ter uma inge rência direta. $\underline{(19)}$

Os estudos de Malloy citados, apontam que a concepção de seguro social que regia os serviços previdenciā rios ("proteção" à família seguxada contra riscos pré-estabelecidos: velhice, doença, invalidez e morte do provedor da fa mília) tendeu, após 64 , a ser ampliada para a noção de segu-

(18) E significativa a declaração do Gen. Geisel no "O Estado de São Paulo" de 05/02/76 anunciando o Pronan: "Deve-se exigir a participação financeira do próprio assalariado e estimular as empresas atravês de de dução dobrada no imposto de renda, para que proporcionem ao trabalhador de menor salário ou aos mais necessitados, uma alimentação adequada. E obviio que os reflexos proporcionados por tal situação serão altamente promissores para a propria empresa que terâ, sem dưvida, maior rendimento do trabalho do operário". Cf.R. Coutisho, op. cit., p. 35.

(19) Ver: J. Malloy. "A Política de Previdência Social no Brasil: Particípação e Paternalismo". Dados n 13, Rio de Janeiro, IUPERG, 1976, p. 93-115; "Previdência Social e Distribuição de Renda. Notas de Pesqui sa". Estudos Cebrap, $n^{8}$ 25, Petropolis, Vozes, s/d, p. 113-134; "Políti= ca de Bem-Estar no Brasil: his tórico, conceitos e problemas." Revista de Administração Pública, $\mathrm{n}^{\circ}$ 10, Ano 2, Rio de Janeiro, junho de 1976 , p. 5-29. 
rança social diretamente derivada da doutrina de Segurança $\underline{\mathrm{Na}}$ cional (20) E expressão dessa alteração tanto a unificação da Previdência em 1967, como a criação do Ministério de Previdên cia e Assistência Social em 1974. A segurança social (incluin do-se aí programas como INPS, FGTS, PIS, salärio família, sa Iārio educação, etc.), tende a expandir a assistência a todos os cidadãos, além de dispor de um carāter preventivista. Inci de, segundo o autor, sobre uma questão chave da economia polí tica "a capacidade da sociedade como um todo gerar poupança para financiar todos os programas sociais, sem romper os programas de desenvolvimento economico" (21) ou, em outros termos, a contradição entre as funções de acumulação e legitimação da dominação burguesa e do Estado capitalista, subjacente a crise do capitalismo. (므)

0 conceito que se sobressai na concepção de "segurança social", que passa a reger os programas de cunho assistencial, é o de salārio social, que incorpora ao salário propriamente dito os värios serviços, bens e "benefícios" que a "coletividade paga" ao trabalhador, passíveis de utilização futura. 0 "salärio social" se adequa, assim, à manutenção de um piso salarial rebaixado, à medida que engloba no conceito de salärio os demais "benefícios", pelos quais o trabalhador se vê impingido a financiar duplamente: alêm do trabalho exce dente que lhe é permanentemente subtraído, paga-os tanto com

(20) "Especificamente, eles (os militares) desenvolveram a noção de que um amplo alcance dos programas sociais reduziria as tensões de classe e contribuiria para a ordem social bäsica e, consequentemente, para a total segurança nacional. Dada a obvia importância "polítiça" de tais pro gramas, eles devem ser monopolizados pelo Estado, que ê o órgão encarre= gado de garantir a ordem e a segurança nacionais. Alêm disso, esses programas, devem ser organizados dentro do programa econômico do Es tado, que, támbém, estâ vinculado à segurança nacional". J. Malloy. "Previdência Social e Distribuição de Renda. Notas de Pesquisa", op. cit., p. 128. (21) J. Malloy. "Previdência Social e Distribuição de Renda.' Notas de Pesquisa". op. cit., p. 128. op. cit.

(22) F. Fernandes. "Apontamentos sobre a "Teoria do Autoritarismo". 
deduções salariais diretas, como arca com o financiamento dos custos das contribuições dos empregadores transferidos para os preços dos produtos, da elevação do custo de vida, etc.

E importante acentuar que a determinação do "salärio social" ao ser definida pelo Estado, ultrapassa as relações de mercado, as negociações diretas entre empregado e empregador, em detrimento da possibilidade de exercício, pelo trabalhador assalariado, de sua cidadania na luta por sua pró pria sobrevivência na sociedade capitalista.

Os programas econômico-sociais passam a ser definidos pelo Estado em função de critérios aparentemente têcnico-administrativos, eliminando, com isto, a função repre sentativa dos grupos interessados, numa linha de "despolitiza ção" desses programas. Como expressão da burocratização crescente das relações sociais, os trabalhadores passam a depender de decisões tomadas na esfera político-administrativa do Estado em questões que afetam sua própria sobrevivência. Estes são alguns contornos da "questão social" no capitalismo monopolista e das formas peculiares de seu enfrentamento pelos setores dominantes nos marcos do Estado Autocrático-Bur guês.

O tratamento da questão social, via repressão e assistência, subordinada aos preceitos da Segurança Nacional e da acumulação monopolista implica não só no agravamento das tensões sociais, como na ampliação do processo de pauperi zação absoluta e relativa dos trabalhadores e das sequelas daí derivadas. A "crise do milagre" econômico brasileiro permite o reaparecimento, na superfície da cena política, da presença fortalecida e reorganizada dos trabalhadores em seus movimen tos sociais, apesar da assistência e da repressão.

Esse quadro conjuntural representarā para os Assistentes Sociais uma ampliação crescente de seu campo de trabalho. Paralelamente, diversificará as demandas feitas ao 
meio profissional no sentido de assumir e enfrentar uma série de tarefas e funções relativas a implementaçäo das políticas sociais, dentro da nova racionalidade que o modelo político impõe. A isso se acrescem os efeitos da burocratização crescente que acarreta a modernização do aparelho de Estado. Este fato que tambèm se reflete no interior das empresas, torna ainda mais necessária a existência de funcionārios especializados nas tarefas de interpretação e encaminhamento para a obtenção de "benefícios" a que se referem aquelas políticas. Assim, observa-se que o crescimento da demanda e exigências que essa conjuntura coloca para o meio profissional nada mais é do que um aspecto da resposta institucional ao agravamento das condições de vida do proletariado. Em outros termos, a ampliação do mercado de trabalho, e o reforço da legitimidade do Serviço Social diante do poder é expressão da resposta das classes dominantes ao enfrentamento das novas formas de expres são da questão social, que tem como pano de fundo a ampliação do processo de pauperização da população trabalhadora, dentro de uma conjuntura em que sua capacidade de luta encontra-se gravemente afetada pela política de desorganização e repressão às suas entidades de classe. Nesse quadro, a instituição Serviço Social deverá capacitar-se a fornecer uma resposta que a atualize, face aos novos desafios que lhe são colocados pela conjuntura político-econômica. Estes se traduzem num repensar da atuação profissional, seja numa linha de tecnificação pragmatista modernizadora, seja numa busca de questiona mento das próprias bases da legitimidade dessa demanda.

Antes de desenvolver as respostas apresentadas pelos Assistentes Sociais a essa realidade, importa retomar e particularizar algumas características desse intelectual no desempenho de suas atividades profissionais, que viabilizam a ampliação de sua demanda pelos setores dominantes. 
5.3. Assistente Social: O Profissional da Coerção. e do Consenso

A identificação das funções intelectuais exer cidas pelo profissional implica em resgatar algumas peculiari dades dessa prâtica profissional. Esta é considerada como uma das dimensões, através da qual o Assistente Social exerce seu papel intelectual, embora este extrapole o âmbito estritamen te profissional.

Tendo por suporte as organizações püblicas e privadas situadas na órbita dos quadros dominantes da socieda de, que atuam na esfera da prestação dos serviços sociais, a intervenção do Assistente Social é, eminentemente, uma ação de cunho "educativo", "organizativo", junto as classes trabalhadoras. Busca transformar a maneira de ver, de agir, de com portar e de sentir dos indivíduos em sua inserção na socieda de. Incide, portanto, sobre o modo de viver e de pensar dos trabalhadores, a partir de situações vivenciadas no seu cotidiano. Essa ação é, no entanto, realizada através da prestação dos serviços sociais, previstos e efetivados pelas entida des a que o profissional se vincula contratualmente. Este tipo de prática vem configurando o Assistente Social como o "profissional da Assistência", enquanto opera com recursos institucionais para a prestação de serviços que se enquadram nesse âmbito, racionalizando e administrando sua distribuição, controlando o acesso e o uso dos mesmos pela "clientela". E um profissional intermediário das relações entre instituição e "clientela", um articulador da população aos örgãos em que trabalha. A prestação de serviços imediatos em que interfere - Assistente Social contribui para fazer frente a necessidades básicas e urgentes de sobrevivência das classes trabalhado ras, especialmente de seus segmentos mais pauperizados, afetando sua reprodução material. E acoplado a esses serviços buscados pela população, que o profissional desempenha suas funções tipicamente intelectuais. 
Este tipo de intervenção profissional viabil za que seus agentes qualificados atuem em organizações de di ferentes tipos e que se dedicam a vários campos de atuação na realidade (saüde, habitação, lazer, trabalho, etc.) fazen do face a uma gama heterogênea de necessidades sociais. Isto possibilita à categoria profissional ter acesso à quase globa lidade das esferas da vida cotidiana dos trabalhadores. O que delimita a solicitação desse profissional não ê, propriamente, o tipo de especialização das instituições e dos serviços que mantêm: a estes deve adaptar-se o profissional, (23), gera 1 mente na condição de um tếcnico do escalão inferior diante das atividades principais do setor, exercidas por um profís sional com especialização técnica específica no campo (médico na ärea de saủde, pedagogo na de educação, etc.). Este quadro se altera nos organismos cujos programas principais se enquadram no campo "social" ou mais precisamente de "assistência", "promoção social" ou "bem-estar social". Aí o Assistente Social tende a ocupar postos principais na hierarquia institu cional, quando não preenchidos por "políticos de carreira",ou por profissionais de outras äreas, em se tratando de cargos de confiança da administração pública e privada.

Esta prätica diversificada, enquanto áreas diferenciadas de trabalho a que se dedica, é vivenciada e repre sentada pelo profissional de maneira confusa: almeja ter um campo "pröprio" de trabalho, enquanto ärea "específica" que The atribua "status" e facilite o seu reconhecimento profissional. Como tende a recusar atividade assistencial, pelos es

(23) Tal adaptação ao perfil da demanda do mercado de trabalho vem se trađuzindo no interior da instituição Serviço Social, pela tendência a se formar especializaçōes: Serviço Social Mẻdico-Hospitalar, Serviço Social do Trabalho ou de Empresas, Serviço Social Previdenciärio, etc. $\mathrm{E}$ a resposta da instituição no sentido de aprimorar a qualificaçã̀o técni ca em resposta à maleabilidade do exercício profissional nos mais diversos "campos" profissionais, que se multiplicam com o aprofundamento da divisão social e técnica do trabalho. 
tígmas que contém (muitas vezes erroneamente identificada com a simples caridade) ele se vê "perdido" diante da definição de seu fazer frente a outras profissões correlatas cujas fren tes de trabalho são mais precisas, seja pelo caráter tếcnico mais marcado, seja pela herança científica mais solidificada. Incorporando, frequentemente, a ótica da compartimentalização das disciplinas como um dado não questionável, o Assistente Social tem a sensação de estar presente em segmentos da reali dade particulares e particularizados, "apropriados" pelas vá rias disciplinas, sem ter reconhecido o "seu" lugar. Sente a profissão diluida, difícil de ser definida e qualificada.

Apesar desse caráter aparentemente difuso e heterogêneo das tarefas exercidas pelo Assistente Social, este continua a ser necessário na presente organização social, o que se expressa no crescimento do mercado de trabalho, nos últimos anos, e na expansão quantitativa da categoria profissional.

$\mathrm{Na}$ busca de explicar o que unifica a demanda do Assistente Social em programas multifacéticos, pode-se le vantar uma hipótese, que direciona as reflexões que se seguem: o que delimita, fundamentalmente, a solicitação desse tipo de profissional, não è tanto o carāter propriamente "têcnico especializado" de suas ações, mas, antes e basicamente, as funções de cunho "educativo", "moralizador" e "dis ciplinador" exercidas mediante um suporte administrativo-buro crático, sobre as classes trabalhadoras, ou, mais precisamen te, junto a seus segmentos que formam a "clientela" das insti tuições que desenvolvem "programas sócio-assistenciais". Radi calizando uma caracteristica de todas as demais profissões, - Assistente Social aparece como o probissional da coerção $e$ do consenso, como um especialista politico. Esta è, pois, uma característica que não lhe sendo exclusiva, aparece, aí, com maior intensidade, tanto pelo significado da atividade assistencial, como pelas características mais peculiares da 
profissão derivadas de sua trajetória histórica e constante mente atualizadas. Sua demanda pelos canais "oficiais" esta relacionada, desde os seus primórdios, às tensões e mudanças significativas nas oposições de classes configuradas na "ques tão social". Encontra-se estreitamente vinculada, como uma atividade secundâria, mas nem por is to dispensāvel, à necessi dade de preservação da ordem, da estabilidade da sociedade civil, como suporte da ampliação da produtividade do traba1ho, requerida pelo processo de acumulação. E dentro desse quadro que se explica, inclusive, o sentido prioritärio das atividades de Assistência Social, sem menosprezar suas deriva

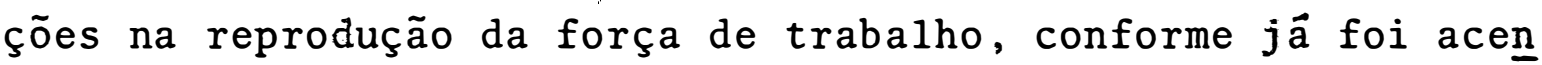
tuado no capítulo anterior. "Paz social" dentro do "progresso" é a diẩde subjacente à necessidade histórica da assistência social e dos profissionais a ela vinculados. Programas e agen tes são mobilizados para detectar, preventivamente, as tensões sociais, e, localizadamente, atenuä-las ante as seque las derivadas da intensificação do processo de exploração da força de trabalho e de sua contrapartida: a presença crescente dos trabalhadores no cenärio político da sociedade, organi zados na luta por seus interesses corporativos e políticos.As atividades assistenciais se recrudescem, especialmente nos pe ríodos de crise, como contraponto a este processo de organiza ção coletiva dos trabalhadores, como "soluções" enfeixadas nas mãos do Estado e dos segmentos de classes a ele vincula dos. Tais soluções se materializam em programas sociais, que individualizam e pulverizam, mantendo sob controle, respos tas à necessidades de carâter coletivo. E principalmente nes se processo de individualização de atendimentos que entra em cena o Assistente Social.

Sendo este o significado prioritário das ativi dades que conformam o "campo" de trabalho do profissional, elas não exaurem aí sua explicação. Quando toda a sociedade encontra-se regida pela lógica da acumulação os serviços so- 
ciais não fogem a seu âmbito, passando a ser estruturados como campo de investimentos, como "locus" de aplicação do capltal. A organização e distribuição dos serviços passa a ser subotdi nada aos quisitos do crescimento ampliado do capital.

Em sintese, a natureza da atuação profissional $\vec{e}$ de cunho predominantemente político-ideológico do que pro priamente econômico. A eficácia de sua atuação junto a clientela é basicamente político-ideológica sob a aparência tecnificada.

Tais elementos levam a direcionar a anālise pa ra a compreensão do papel intelectual desempenhado pela categoria profissional. Assim o foco analítico não se circunscreve a nível da própria categoria profissional; incorpora-a, ul trapassando-a, para buscar esboçar como o exercício das fun ções intelectuais se peculiarizam nesse profissional. Enfim, apreender algumas particularidades do intelectual Assistente Social.

0 pressuposto assumido foi de que a análise so ciológica da profissão e de seus agentes não pode ser reduzí da à consideração do Serviço Social e do Assistente Social des vinculados dos organismos institucionais, cujo caráter e fun ção condicionam o significado dessa prātica profissional no processo de reprodução das relações sociais. Tal premissa re mete a um aprofundamento da concepção do intelectual, apoiada em Gramsci, (24) visto que possibilita superar a consideração

(24) A. Gramsci. "Problemas da Vida Cultural" In: Obras Escolhidas, op. cit.; A. Gramsci. Os Intelectuais e a Organizaçâa da CuItura. Rio de Janeîro, Civilização Brasileira, 3a. ed., 1969. H. Portelli. Gramsci e o Bloco Histórico, op. cit.; M. A. Macciocchi. A Favor de Gramsci. Rio de Janeiro, Paz e Terra, 2a. ed., 1980. J.M. Piotte. El Pensamzento Politico de Gramsci. Barcelona, A. Redondo, 1972. A anălise do intelectual incorpora a interpretação apresentada por Piotte. Não se pretende efetuar uma discussão teóricca da noção, mas retomar e ampliar alguns elementos básicos da concepção do intelectual jâ explicitada, para subsidiar a com preensão de certas particularidades do Assistente Social como intelec= tual. 
dos aspectos puramente profissionalizantes, atrelando-os à sua significação política, priorizando a função e o lugar que essa camada ocupa no bôjo das relações sociais.

Reafirmando o que jâ foi dito, Gramsci apreseri ta uma noção ampla de intelectual, conferindo uma significação histórico-sociológica a esta noção, definida a partir do lugar e da função que ocupa no seio da estrutura social e no processo histórico. Refutando a mera segmentação entre trabatho manual e intelectual, parte do suposto de que todos os homens são intelectuais, na medida em que sempre utilizam, em graus diferenciados, sua capacidade cerebral. Sustenta, no entanto, que nem todos exercem, no conjunto das relações sociais, a função de intelectual. E esta função que cumpre ressaltar.

Sendo os intelectuais representantes de interesses econômico-corporativos e políticos de uma classe, e, não apenas portadores de interesses privados, suas funções en contram-se estreitamente articuladas a posição e a função que as classes fundamentais (proletariado e burguesia) ocupam na sociedade. (25)

(25) Conforme Piotte, as funções dos intelectuais podem ser resumidas en que:

- são organizadores da função econômica da classe a que se articulam, e xercendo tarefas no mundo da produção que são especializações de atividā des em sua origem exercidas pelos membros ativos dessa classe;

- são organizadores da coerção de classe exercida a nível do Estado, atra vês de seus quadros administrativos, políticos, jurídicos e militares;

- são portadores da função de hegemonia que a classe dominante exerce so bre o conjunto da sociedade civil através das organizações culturais (es colas, meios de commicação e de difusão) e dos partidos, buscando asse= gurar o consentimento, senão ativo, pelo menos passivo, das classes domi nadas à direção imprimida à sociedade;

- têm, ainda, o papel de favorecer a tomada de consciência da commidade de interesses da pröpria classe que representam, homogeneizando sua concepção de mundo. Is to é, buscar a correspondência entre esta concepção e a função objetiva dessa classe, nuna dada situação histórica. Ver: J. M. Piotte, op. cit. 
0 intelectual exerce funções de direção econô mica, social e cultural que se expressam tanto nos níveis de elaboração como de difusão do saber próprio da classe que representa. Pode-se caracterizar o papel do intelectual como o de investigador, educador, organizador de hegemonia e da coe $\underline{r}$ ção e, ainda, homogeneizador da consciência da classe.

Se o vínculo do intelectual com a classe por este representada $\vec{e}$ orgânico, essa camada social dispõe de uma relativa autonomia no exercício de suas funções. A compre ensão desse duplo movimento de organicidade e autonomia é bāsica para se ter clareza do papel do intelectual.

Ainda segundo Piotte a anālise gramsciana do intelectual orienta-se para a organização de classe, voltada para sua preocupação com o partido, configurado como o intelectual coletivo. Em outros termos, os laços que unem os intelectuais às classes sociais procedem das organizações da so ciedade civil e da sociedade política, nas quais atuam e a cu jos propósitos confirmam sua adesão. Assim o caräter orgânico do intelectual estã na estreita dependência dos vínculos que essas organizações mantêm com as classes fundamentais, sen do a organicidade tanto maior quanto mais estreitas são as relações entre ambas. O grau de organicidade do intelectual está, ainda, condicionado pelo lugar que ocupe dentro da hie rarquia das organizações hegemônicas e corporativas da sociedade civil e nos organismos do Estado: quanto mais elevada a posição mais intima a organicidade.

Esta vertente analítica supõe, portanto, com preensão, numa dada situação histôrica específica, das classes e de suas relações, bem como dos organismos atravês dos quais se expressa e consolida sua influência numa sociedade determi nada. Ela é básica para a análise do tema em debate: o papel do Assistente Social. Não sendo este um profissional liberal mas sua atuação realizada atravês dos organismos da sociedade civil e, especialmente do Estado, estes constituem as "pontes" 
das relações entre o profissional e as classes sociais. Apreender, portanto, o carāter de classe das organizações nas quais trabalha o profissional, na condição predominantemente de um intelectual subalterno face a estrutura de poder das mesmas, é condição para se desvendar o significado dessa ins tituição e os efeitos sociais da prätica de seus agentes.

Importa ressaltar que, para Gramsci, a nature za de classe da ação do intelectual, não se encontra na depen dência imediata de sua origem de classe sobre a qual predomi na a sua função social. À sua origem social, sobrepuja-se o espaço problemâtico a partir do qual orienta e implementa sua atividade, isto é, sua posição de classe, e a natureza das or ganizações através das quais exerce suas funções organizativas, educativas, e de elaboração do saber. Historicamente, a "pequena burguesia rural e urbana" se apresentam como as cama das, por excelência, produtoras de intelectuais que, tendem a ser incorporados pelos "grupos sociais" fundamentais em sua luta pela hegemonia no conjunto da sociedade.

Porém os intelectuais não são meros reflexos das classes sociais e nem simples membros das mesmas: seu vîn culo orgânico supõe que representem a autoconsciência crítica dessas classes. O exercício de seu papel intelectual supõe uma criticidade, o que o indispõe, muitas vezes, com a classe representada, mạs sem colocar em questão o seu poder econômico, político e cultural. A relativa autonomia que mantẻm a ca mada dos intelectuais é derivada da particularidade de suas funções, como do vínculo com as organizações que produzem uma certa "distância" entre o intelectual e a classe. Configurados como uma categoria específica, os intelectuais criam sua pröpria rêde de organizações representativas, com uma certa independência das classes dominantes, para a defesa de seus interesses corporativos específicos. 
Esta relativa autonomia, indissociāivel da orga nicidade, favorece a construção de representações por esses agentes em que apresentam como camadas efetivamente indepen dentes, o que aparece de forma mais marcante, mas não exclusi va, nos intelectuais tradicionais, vinculados a classes que perderam ou vêm perdendo seu peso político e econômico na sociedade decorrente da própria expansão capitalista.

Incorporando esta rápida disgressão teórica pa ra a compreensão das características da atividade profissional do Assistente Social como uma das instâncias em que efeti va seu papel intelectual, importa retomar, articulando na ana lise, elementos $j \vec{a}$ apontados.

A posição do Assistente Social na organização e divisão de trabalho a nível do processo produtivo, dentro das unidades industriais, pode ser pensada como desdobramento de uma das funções originais do capitalista no âmbito da produção, delegada, posteriormente, a seus quadros técnicos admi nistrativos: a de controle e disciplinarização dos operārios tendo em vista sua subordinação aos requisitos do processo de valorização.

Porém, as atividades controladoras e educat $\underline{i}$ vas executadas pelo Assistente Social não se restringem ao âm bito fabril. Trabalhando a partir da unidade familiar do trabalhador abrange, tambëm, a esfera de sua vida privada, extra-fábrica. Isso se dâ seja atravês do acesso à vida particu lar do operário, e a seu ambiente doméstico, seja atravês da interferência na sua capacidade e decisões de consumo, median te o poder que the é delegado na administração dos "beneficios sociais", enquadrados na concepção do salário indireto, ou, mais precisamente de "salário social".

Enquanto as tarefas de organização das relações industriais são partilhadas por uma equipe de profissionais, entre os quais o Assistente Social, a área dos "benefí- 
cios" e das "relações empresa-comunidade" the tem sido atri buídas com certa exclusividade.

Sua posição funcional nas indüstrias encontrase predominantemente ligada à administração de pessoal, partị cipando da implementação e, em menor escala do planejamento, de programas voltados para a "humanização" das relaçōes de trabalho. Essas medidas, balizadas pela necessidade de garan tir níveis ótimos de produtividade do trabalho, estão voltadas não sō para atenuar as manifestações de insubordinação dos operários face à rígida disciplina imposta ao trabalho e ao trabalhador alienado, como para detectar a eclosão de ins a tisfações potenciais, e propor medidas, atreladas à hierarquia da Empresa, que esvaziem o potencial organizativo e reivindicatório do proletariado. $\underline{(26)}$

A empresa tem no Assistente Social um dos técnicos privilegiados para exercer o papel de mediador entre a indústria e a vida privada do operārio. Este é efetivado atra vês da discussão de suas relações e dificuldades cotidianas, e do conhecimento de suas condições de sua vida doméstica, verificadas "in locu" por meio de "visitas domiciliares". 0 profissional não só invade o cotidiano do trabalhador, mas propõe e realiza programas que procuram "cooptar" algumas de suas esferas, trazendo-as para "dentro da fábrica", atravês da realização de atividades de lazer, esportivas, culturais, de confraternização da família operária, concursos, etc. Atra vês de programas voltados para a integração empresa-comunidade concretiza o estabelecimento de fios articuladores no con-

(26) Encontram-se, ai, atividades como: verificação e controle do absenteísmo; orientação e interferência nos conflitos entre operärios e entre estes e as chefias imediatas; verificação, a nível da história de vida individual, de fatores geradores de "displicência" no trabalho ou de queda da produtividade, de operärios particulares; interpretação e orientação de normas de segurança do trabalho; treinamentos de lideranças; incentivo à criação de canais de participação e organização dos ope rärios na vida da empresa, atravês de grupos e comissões supervisionadas por agentes da administração, etc. 
trole do uso do tempo livre do trabalhador resgatado historicamente do capital, propondo alternativas de seu preenchimento dentro da órbita da empresa.

A mediação exercida pelo Assistente Social nas relações entre a indústria e vida privada do trabalhador se efetiva ainda, pelo controle do acesso e uso dos chamados "be nefícios", previstos pela política de pessoal da empresa (empréstimos financeiros, adiantamentos salariais para necessida des urgentes, cooperativas de consumo, etc.) e pela politica previdenciāria. Esta área se revela como uma instância privilegiada de interferência em decisões que, no capitalismo, têm sido atribuî́das ao próprio trabalhador, sem uma ingerência di reta do capital. Trata-se de um empreendimento de tutela e programação do cotidiano operário, incutindo-lhe uma racionalidade de comportamento adequada à order capitalista.

Este trabalho persuasivo e coercitivo, aqui ressaltado a nível do Serviço Social na indústria, se repete com algumas particularidades nos demais campos de trabalho do Assistente Social em organizações da sociedade civil, e do Es tado, sendo este sua principal instância mandatária. 0 profissional encontra-se presente em suas esferas administrati vas, políticas, jurídicas e, mais recentemente, nas forças ar madas. Por outro lado è significativa sua ausência em organizações e associações próprias da classe trabalhadora, por ela criadas e geridas, assim como de vínculos diretos com seus mo vimentos sociais autônomos. Mesmo as entidades sindicais, es truturadas dentro da política corporativista do Estado, não têm solicitado os serviços desse profissional, nem mesmo naquelas atividades que se vêm, muitas vezes, constrangidos a realizar no campo da assistência social. Importa registrar, no entanto, que, atualmente segmentos profissionais minoritários, identificados com as lutas populares, vêm realizando ex periências de trabalhos pioneiras, embora ainda restritas, na 
assessoria a movimentos sociais de trabalhadores, independen te da mediação de instituições do Estado.

Se a base organizacional através da qual atua o Assistente Social apresenta um nítido caráter de classe, o vínculo com os propósitos da mesma passa pela adesão desse intelectual aos interesses sociais objetivos que aquelas organizações buscam sedimentar no conjunto da sociedade. Essa adesão é um pressúposto para o exercício de seu papel intelec tual. Assim, o significado social que a instituição Serviço Social vem desempenhando na sociedade capitalista, na intimidade do poder dominante, não é independente da conivência at $\underline{i}$ va ou passiva de seus agentes, incorporando un projeto social que se expressa nos rumos assumidos por sua prätica. Isto re mete à necessidade de compreender quem è o profissional dé Serviço Social e as mediações peculiares existentes em suas relações com as classes sociais.

Se nos seus primórdios os pioneiros dispunham de uma origem de classe definida, oriundos dos setores abasta dos da sociedade, com o evoluir da instituição verifica-se um alargamento das fontes de recrutamento, acompanhados ao mesmo tempo, de um processo de secularização relativa (27) e de "pụ rificação profissional", ou profissionalização. Os Assistentes Sociais passam a ser provenientes, em grande medida, dos setores médios urbanos, que almejam, numa profissão universitâria ascender socialmente e obter meios de sobrevivência através de uma atividade remunerada. Mas este fator não é su ficiente para elucidar a procura do curso de Serviço Social ao se constatar o precário "status" da profissão e o baixo ní

(27) Coube, historicamente à Igreja o quase monopólio da formação profissional desses agentes. A maioria das Faculdades ainda, hoje, ê católica, ampliando o seu processo de incorporação âs Universidades do Estado. Este delegou à Igreja a tarefa de qualificação dos Assistentes So, ciais, subsidiando, financeiramente, os centros de formação, mas sem gé ri-los diretamente. 
vel salarial face a outras alternativas vigentes no mercado de trabalho que propiciam melhores possibilidades aqueles que priorizam galgar postos mais rentáveis na sociedado. Ingres sa, ai, outro fator importante: busca-se, também, uma profissão que veicule vantagens simbólicas, no campo da "solidariedade humana", da "realização pessoal", da oportunidade de rea lizar uma "vocação", inspirada em motivações religiosas ou claramente politicas. Trata-se de uma profissão que incorpora a mistica do "servir", da ajuda, guiada por valores "nobres" e altruístas, de caráter não utilitário (28). Portanto, busca-se no Serviço Social alêm de uma remuneração econômica, uma possibilidade de "recompensa pelo dever cumprido". Outro dado não desprezível, é a configuração da profissão como "se tor de refugo", face a outras alternativas de escolha. (29).

A compreensão desse perfil peculiar passa pe las características de ser uma profissão basicamente feminina,

(28) Pesquisa realizada em 1967 , junto a estudantes de todas as esco las de Serviço Social do Brasil, patrocinada pela ABESS, então Associa ção Brasileira de Escolas de Serviço Social, con a participação entre ou tros de Otávio Guilherme Velho e Pedro de Assis Ribeiro, revela os principais motivos que levam a procura do curso de Serviço Social. São eles: "vontade de ser ütil", "querer ajudar os outros" e "contribuir para o de senvolvimento do paîs", 32,7\%; "achou que tinha vocação", "meio de se realizar", 25,3\%; "arranjar mel hor emprego", 11,6\%; exclusão de outras profissões, 10,4\%; "ampliar conhecimentos", 5,2。; "gosto da profissão", "de lidar com pessoas", 4,0\%; "influência de outra Assistente Social"; $1,1 \%$; "teste de orientação vocacional", $0,4 \% ;$ e outros, $9,3 \%$. Dentre os "outros motivos" são destacados: privilégios obtidos pelos funcionấrios pûblicos com curso de nível superior e falta de outras escolas de nível superior que despertasse maior interesse ao candidato. A referida pesqui sa mostra, ainda, que $90 \%$ dos estudantes são do sexo feminino, incidência elevada tambêm encontrada en outras profissões como: Enfermagem, Biblioteconomia, Museologia, Müsica, Nutrição e Obstetrícia, conforme dados da CAPES. Ver: Valores e Serviço Social. Contribuição ao XIV Congres so Internacional de Escolas de Serviço Social. Helsink, ago. 1968. Rió de Janeiro, 1968. Sobre as vantagens simböticas obtidas e procuradas na profissão ver, tambêm, Jeannine Verdès-Leroux, op. cit.

(29) Tal característi ca é tambêm constatada por J.Verdès-leroux, op. cit. 
que incorpora o peso da educação da mulher e da imagem cons truída socialmente em torno da feminilidade pela cultura doni nante.

A imagem social da profissão e do profissional encontra-se profundamente estigmatizada pelos estereótipos criados em torno da mulher, aparecendo como uma extensão profissionalizante de seu "papel na sociedade", como uma alterna tiva a vida doméstica e a participação política. A figura da mãe, da educadora e do sacerdote se mesclam na imagem social dessa profissão, de precâria base têcnico-científica que, his toricamente tendeu a valorizar "dons", os atributos de classe "naturalizados" como essenciais à tarefa educativa e moraliza dora junto às classes subalternas. (31)

Este tipo de educação social predominante a que é submetida a mulher, especialmente aquelas oriundas de colégios católicos, permite facilitar a constituição de profissionais de setores subalternos, porêm, identificados ideologicamente com a cultura dominante, e com o projeto de socie dade que ela expressa. Muitas vezes, características de classe tendem a se erigir como atributos profissionais. 0 componente humanitário, dentro de uma utopia conservadora, é conso lidado aí, na mística da ajuda, contribuindo para a legitimação da profissão diante de seus prōprios agentes, como uma profissão especial, que antes de ser trabalho é missão.

(30) Este raciocínio se apöia na obra anteriormente citada. São tidos como atributos essenciais às mulheres, entre outros: seriedade, modéstia, gosto de servir, negação de si mesma: esquecer-se, dar-se, devotar-se, sacrificar-se; capacidade de "entrar" na vida alheia, de compre ender os demais, dotada de fina intuição peculiar. Educada atravês de una repressão sexual moralizadora e infantilizada diante do sexo oposto, busca-se reforçar, ideologicamente, certas aptidões "naturais" que a sen sibilizam de modo especial para o trabalho a "serviço da commidade".

(31) Atê a dêcada de 70 , pelo menos, a seleção para as Faculdades de Serviço Social incluia, alëm do exame vestibular, a exigência de testes vocacionais, realizados por especialistas, que buscavam detectar as apti dões e tendências pessoais do candidato à profissão. 
Essas caracteristicas contribuem para que as relações entre o Assistente Social e as classes trabalhadoras se emoldurem numa dimensão tutelar, marcada pelo paternalismo autoritário. O profissional tende a reproduzir suas disposi ções e comportamentos de classe junto ao "povo", à medida que defronta-se com um modo de vida que, a princípio the é estranho, apresentanto-o como "problemático", "anômico", "amoral" e "desajustado". A clientela tende a ser infantilizada e estigmatizada pelo profissional, desqualificada diante de si mesma pelas suas condições de vida e pela sua maneira de en frentar e resistir à vida. Essa incriminação esteriotipada evoca pretensões universalizantes da burguesia, que busca im primir, atravês de seus intelectuais, parâmetros de sua racio nalidade ao cotidiano da vida operäria. A prática do Assisten te Social está, ainda, muitas vezes voltada, para o preenchimento de funções de intelectuais da classe trabalhadora, atrí buindo-se um papel de porta-voz e representante de seus interesses ou cooptando lideranças, formando-as e orientando-as numa perspectiva de mútua colaboração entre as classes, de neutralização de tensões.

Porquanto essas características evidenciam ele mentos favorecedores da cooptação desse intelectual pela burguesia e seus aliados, partilhando de seu "partido ideológi co", nos termos de Gramsci, deve ser, ainda, destacado como se expressa a relativa autonomia em relação às classes que es se intelectual dispõe e como a representa.

Esta autonomia é característica de suas próprias funções intelectuais que exigem uma certa distância crí tica face as classes sociais a que se vincula, embora circuns crita a seus horizontes; deriva, tambëm da autonomia relativa das organizações em que trabalha o Assistente Social frente as classes que as constituiram. Aqueles organismos institucio nais, dispondo de funções específicas na sociedade, não são meros reflexos dos interesses dominantes: concretizam e ex- 
pressam as polarizações sociais presentes numa dada situação histōrica. Seu vínculo com o poder é mediado pelo jogo das forças sociais dentro de quadros conjunturais específicos.Por outro lado, o exercício profissional aí efetivado supõe a delegação de una parcela de poder de decisão ao Assistente Social que se exprime na definição de suas atividades, da mane ra de conduzi-las, assim como em suas relações com a "cliente $1 a^{\prime \prime}$. A própria fluidez das tarefas desempenhadas pelo profissional e sua flexibilidade de adaptar-se à condições diferenciadas de trabalho, faz com que, ocupar um cargo signifique, muitas vezes, estabelecer suas pröprias atribuições e ativida des a partir das solicitações feitas pelo empregador, confirmando-as ou adequando-as aos preceitos profissionais.

Ainda o fato do Serviço Social ser regulamenta do como uma profissão liberal, embora em choque com a sua prá tica efetiva dependente de uma relação contratual de trabalho com as entidades empregadoras, atribui ao profissional certas prerrogativas, como o respeito a um côdigo de ética, que the preserva um certo poder de barganha diante das instituições, na defesa de suas pröprias iniciativas.

$\mathrm{Na}$ procura de consolidar as bases de legitima ção legal e social da profissão os Assistentes Sociais criaram uma profícua rede de meios de expressão de seus interesses corporativos. Esta se consolida em atividades de culto à pro fissão (seminários, congressos internacionais e nacionais, ge ralmente prestigiados e avalizados pela presença de altas figuras governamentais e eclesiảsticas), na criação de örgãos próprios de difusão, de conquista de uma legislação profissio nal, e de uma malha de associações e entidades profissionais, de âmbito nacional, regional e 1ocal. (32) Conquistas expres-

(32) Pode-se arrolar os seguintes dados que ilustram a afirmação fei ta: Em 1946 é criada a ABAS - Associação Brasileira de Assistentes Sociais, com ramificações estaduais através das APAs - Associações Profissionais de Assistentes Sociais. No mesmo ano é criada a ABESS - Associação Brasileira de Escolas de Serviço Social e, posteriormente, Associa- 
sivas foram obtidas a nível da regulamentação da profissão e do ensino especializado. (33) Estas lutas voltadas para o reconhecimento profissional e preservação de seus privilégios no mercado de trabalho, reforçam o "espirito de casta" dos Assistentes Sociais, mas pouco avançaram no processo de organização política da categoria, nas lutas por reivindicações trabalhistas e salariais, tendência eșta que só vem revertendo nos ültimos anos. Ao conträrio, tenderam a significar a re novação de manifestações de adesão ao poder, não eliminando conflitos secundảrios no bôjo das negociações das reivindicações em pauta. Contribuiram, no entanto, para reforçar a auto-definição desse intelectual como autônomo e independente das classes sociais. A esse movimento se aliam os componentes oriundos do humanismo cristão, de origem metafísica, em que o Homem "in abstrato" ocupa o lugar das classes sociais, obscurecendo para o próprio agente suas relações com as instâncias

ção Brasileira de Ensino em Serviço Social, de ânbito nacional, organiza da atravẻs de regionais. En 1957 surge o primeiro sindicato de Assistentes Sociais em Porto Alegre. Em 1962 e criado o CFAS - Conselho Federal de Assistentes Sociais, e os CRAS - Conselhos Regionais de Assistentes Sociais, vinculados ao Ministério do Trabalho. Marca presença, ainda, o Comitê Brasileiro de Conferência Intermacional de Serviço Social (ICSW) logo Comitê Brasileiro de Cooperaf̧ão e Interçâmbio de Serviços Sociais, entidade têcnico-cientifica, com arpla influência no meio profissional. En 1940 começa a ser publicada com regularidade a Revista Serviço Social. que perdura atê a década de cinquenta. Em 1965 é lançada a Revista Debates Sociais pelo CBCISS e em 1979 começa a ser publicada a Revista Serviço Social e Sociedade, em São Paulo. A respeito dos principais Congres sos de Serviço Social no país, atē a dêcada de 60 , ver M.V. Iamanoto $\bar{e}$ R. de Carvalho. "Relatörio Final da Pesquisa sobre a História do Serviço Social no Brasil", op . cit.

(33) Dentre essas conquistas se destacam: Portaria 35, de 19/04/49, do Ministério de Trabalho, Indüstria e Comércio que enquadra dos Assistentes Sociais no $16^{\circ}$ grupo das profissões liberais; Lei 1.889 , de 13/ 06/53, que regulamenta o Ensino do Serviço Social, regulando os seus objetivos, estruturação e prerrogativas dos portadores de diploma de Assis tente Social e Agente Social; Lei 3.252, de 27/08/57, que regulamenta $\overline{0}$ exercício profissional; Decreto 994 , de $15 / 05 / 62$, que regulamenta a Lei anterior e cria o CFAS e os CRAS; Portaria Ministerial de 04/12/62, que fixa o currículo mínimo e a duração do curso de 4 anos; Código de Etica aprovado pelo CFAS, em 08/05/65. 
mandatărias, contribuindo para fazê-10 incorporar o empreendi mento cultural que the é delegado. Concorre, ao mesmo tempo, para mascarar, junto à "clientela", as posições de classe que veicula. A isto se acresce o precário "status" da profissão que reforça para o Assistente Social sua auto-imagem de um in telectual independente do poder.

De outro lado, o processo de ampliação da cate goria profissional junto a "classe mêdia", que vivencia os re sultantes de uma politica econômica que nem sempre the é favo rāvel, alarga as possibilidades do Assistente Social perceberse e identificar-se como trabalhador assalariado, condição que o integra, objetivamente, ao conjunto das lutas gerais dos trabalhadores.

Todos esses fatores se somam na . configuração de uma consciência profissional profundamente ambigua, em que se constata uma ampla distância entre propósitos anunciados e os resultados da ação. Mobilizado por motivações pessoais e pela "boa intenção" de solidariedade humana aos setores mais pauperizados e oprimidos da sociedade, o profissional acredita, frequentemente estar trabalhando para os interesses do "povo". Porêm sua crença e subvertida através de sua prática, transmutando-se em resultados que negam as representações de seu fazer. Confunde, frequentemente, intenções com o resultado e significado social de sua intervenção profissional na so ciedade. Essas indicações trazem alguns elementos para compre ender algumas das particularidades do intelectual Assistente Social: ele não se enquadra na linha dos grandes pensadores, dedicados às atividades de elaboração científica, e de criação do saber. (34) Sendo o Serviço Social uma disciplina de

(34) 0 acervo das atividades de investigação e pesquisa no Serviço Social extremamente parcimonioso, assim como daquelas atividades volta das para a sistematização teörica de sua prätica. Tal se reflete na exígua literatura profissional publicada, quando comparada a outras profissões da ârea das Ciências Sociais. 
intervenção na realidade, as atividades de elaboração teôrica não têm sido o eixo do labor profissional. Ao conträrio, eme gindo na tendência verificada na sociedade capitalista de segmentação entre teoria e prática, tem se perfilado como ưma atividade predominantemente prätica, de aplicação de conhecimentos produzidos em outras instâncias, para a introdução de mudanças imediatas no contexto social.

Assim sendo, o papel desse intelectual tem si do basicamente instrumental, de difusão de teorias e ideolo gias, de articulador das classes trabalhadoras na örbita das instituições do poder de classe. Ou seja, exerce suas funções intelectuais principalmente como educador, organizador da hegemonia e da coerção das classes a que se vincula objetivamen te. Essas funções são exercidas atravês da mediação dos servi ços sociais, previstos pelas instituições e procurados pelos "clientes", ao mesmo tempo em que se torna um intermediärioen tre aquelas organizações e a vida privada do trabalhador, invadindo e interferindo nas esferas particulares de sua vida cotidiana.

Trata-se de um intelectual subalterno, um pro bissional da coerção $e$ do consenso, predominantemente articulado a burguesia como integrante de seu "partido ideológico". Mas ê, tambêm, um profissional que vivencia uma tensa ambigui dade: incorporando uma utopia reformista conservadora, de cunho humanitário-cristão, suas representações convivem em tensão com os resultados de sua prática.

\subsection{O Serviço Social Face à "Questão Social" no Capitalis mo Monopolista}

0 propösito deste item final ê acentuar algu mas particularidades do processo de reformulação por que passa a instituição serviço social para fazer frente as novas ca racteristicas da "questão social", em um quadro de aprofunda- 
mento do capitalismo monopolista na sociedade brasileira e de um novo padrão de dominação instaurado pelo "Estado Auto crático-Burguês". Coloca-se em relevo as respostas dadas pelos Assistentes Sociais, expressas na adequação do dircurso e do projeto de prática profissional à correlação de forças en tre as classes sociais nessa conjuntura histórica particular.

Se os desafios de revisão teórico-prâtica da profissão, colocados pelo prôprio momento histôrico, atingem globalmente a instituição, as respostas dadas por seus agentes tendem a se polarizar diante das forças sociais presentes. Ou seja, elas conformam maneiras diferenciadas de apreender $e$ viver a crise profissional e a confirmaçäo ou alteraçäo das bases legitimadoras desse exercicio profissional na sociedade de classes.

Este é um fato novo na história do Serviço So cial brasileiro. E nesse período que parcela da categoria pro fissional tenta romper o compromisso historicamente estabelecido com os interesses dominantes, consolidando questionamentos à tradição conservadora do Serviço Social. E nesse momento que a instituição e parcelas de seus intelectuais se cindem pela polarização do confronto de classes, começando a ma car presença no meio profissional de Assistentes Sociais correntes de pensamento que contestam, em diversos niveis, as präticas institucionais e o compromisso teórico com o conservadorismo presente nas Ciências Sociais.

E esse processo que se busca caracterizar, res gatando algumas marcas de origem da profissão na elaboração daquelas respostas, ou seja: a atualização e a ruptura com a herança conservadora do Serviço Social. No decorrer da anälise procura-se, ainda, compreender a ambiguidade presente no Serviço Social, expressa pela defasagem entre intenções e re sultados da prática profissional no cotidiano da vida em sociedade. 
$\mathrm{Na}$ vertente modernizadora, que vivencia a cri se profissional como atualização da instituição e reforço de suas bases de legitimação junto as instâncias mandatârias, acentuam-se as mudanças de forma do discurso e dapratica, manti dos os vinculos do intelectual com o poder.

$\mathrm{Na}$ tendência que se lança na tentativa de rưptura com a herança conservadora do Serviço Social, problemati za-se os requisitos e dificuldades vivenciadas pelo intelec tual que se orienta para um outro projeto de sociedade, através de uma prática efetivamente inovadora.

\subsubsection{A Herança Conservadora do Serviço Social e sua Atualização}

A compreensão das respostas dadas pelos Assistentes Sociais às novas determinações da "questão social" no capitalismo monopolista implica em retomar algumas marcas de origem da profissão que subsistem, hoje, redefinidas e que con ferem certos traços peculiares ao exercício desses profissionais. O objetivo é, em primeiro lugar, situar essas marcas de origem no bôjo do reformismo conservador; em segundo lugar, acentuar como essa prática e sua justificação teórico-ideológica mudam de forma, preservando, no entanto, seus compromissos sócio-políticos com o conservadorismo, no decorrer da evo 1 ução do Serviço Social. (35)

O Serviço Social, como profissão inscrita na divisão do trabalho, surge como parte de um movimento social mais amplo, de bases confessionais, articulado à necessidade de formação doutrināria e social do laicato, para uma presen

(35) Não se trata de efetuar uma reconstrução histórica do Serviço Social no Brasil, mas apenas de resgatar certos traços de origem para os propósitos supra referidos. A retomada sintética de características da profissão no passado e de sua ins erção na sociedade da êpoca estã baseada em: M.V. Iamanoto e R. de Carvalho. "Relatôrio Final da Pesquisa sobre a His tôria do Serviço Social no Brasil", op. cit. Consultar, tambêm, R. de Carvalho: 'Modernos Agentes da Justiça e da Caridade", op. cit. 
ça mais ativa da Igreja Catölica no "mundo temporal", nos in cios da década de trinta. A Igreja supera a postura contempla tiva, na tentativa de recuperação de ảreas de influência e privilégios perdidos, face a crescente secularização da socie dade e às tensões presentes nas relações entre Igreja e Estado. Fortalece-se defensivamente, organizando e qualificando seus quadros intelectuais laicos, sob a orientação direta da hierarquia, para uma ação missionäria e evangelizadora junto à sociedade. Contrapõe-se aos princípios do liberalismo e ao comunismo, que parecem como um perigo ameaçador a sua posição na sociedade. O movimento de "reação católica" é respaldado em uma vasta rede de organizações difusoras de um projeto de recristianização da ordem burguesa, sob o imperativo ético do comunitarismo cristão, exorcizando-a de seu conteüdo liberal. Luta, ainda, a Igreja, pela legitimação jurídica de suas áreas de influência dentro do aparato de Estado. (36)

Ö debate sobre a "questão social" atravessa to da a sociedade a partir das grandes mobilizações da classe operäria nas duas primeiras décadas do século, obrigando o Es tado, as frações dominantes e a Igreja a se posicionarem diante da mesma. E encarada pela Igreja segundo os preceitos esta belecidos nas Encíclicas papais (especialmente Rerum Novarum e Quadragesimo Anno) as quais são a fonte inspiradora das posições e programas por ela assumidos diante dos "problemas so ciais". A "questão social" é vista como uma questão moral $e$ religiosa, antes de ser econômico-política. A sociedade é tida como um todo unificado, através de conexões orgânicas exis tentes entre seus elementos, que se sedimentam através das tradições, dogmas e princípios morais de que a Igreja é depo-

(36) Dentre a vasta rede de entidades catölicas que dão suporte ao processo de mobilização do laicato pode-se citar: 0 Centro D. Vital, 0 Instituto de Estudos Superiores, a Ação Universitäria Católica, a Liga Eleitoral Católica, os Círculos Operärios criados a partir de 1932. Em 1935 é criada, segundo moldes europeus, a Ação Catōlica Brasileira com ramificações no meio estudantil, operärio, etc. 
sitäria. Deus ê a fonte de toda a justiça, e apenas uma socie dade baseada nos princípios cristãos pode realizar a justiça social. A intervenção do Estado na "questão social" ë legítima, enquanto deve servir ao bem comum. O Estado deve preser var e regular a propriedade privada, impor limites legais aos excessos de exploração de força de trabalho e, ainda, tutelar os direitos de cada um, especialmente daqueles que necessitam de amparo. Porém o Estado não pode negar a independência da sociedade civil. Entre ele e os indivíduos existem os grupos sociais "naturais" (família, corporação, nação, etc.), orga nismos autônomos, mais que mera soma de indivíduos, que limi tam a ação dominadora do Estado. Deve a Igreja compartilhar com o mesmo a atuação diante da "questão social", na tarefa de recristianização da sociedade atravês dos grupos sociais bāsicos, especialmente a família. Impõe-se uma ação doutrinăria e organizativa junto ao proletariado, livrando-o das influências da vanguarda socialista do movimento operärio, harmonizando as classes em conflito com base no comunitarismo cristão. (37)

A partir desse suporte analítico e dessa estra tégia de ação a Igreja deixa de se antagonizar com o capita lismo, concebendo-o atravểs da terceira via, em que o socia lismo é veementemente combatido e o liberalismo substituído pelo comunitarismo cristão.

(37) Ver: R. Della Cava. "Igreja e Estado no Brasil no Século XX". Estudos CEBRAP, $n^{\circ} 12$, São Paulo. Cebrap, 1975; A.C. Villaça. O Pensamento Catölico no Brasil. Rio de Janeiro, Zahar, 1975; T. Bruneau. O Catolicismo Brasileiro em Epoca de Transição. São Paulo, Loyola, 1974; L. W. Vianna. Liberalismo e Sindicato no Brasil: Rio de Janeiro, Zahar,1975; J.A.R. Rodrigues. Sindicato e Desenvolvimento no Brasil. São Paulo, Dife1, 1968; A.A. Lima. A Fundação das Duas Primeiras Escolas de Serviço Social no Brasil. Dissertação de Mestrado apresentada à Escola de Serviço So cial da PUC-RJ. Rio de Janeiro, 1977 (mimeografado); M:C. Yasbeck. Estū do da Evolução Histórica da Escola de Serviço Social de São Paulo no período de 1936-1945. Dissertação de Mestrado apresentada à PUC-SP. São Paulo, 1977. 
Incorporando esses princípios o Serviço Social surge da iniciativa de grupos e frações de classes dominantes, que se expressam atravês da Igreja, como um dos desdobramentos do movimento do apostolado leigo. (38) Aparece como uma das frentes mobilizadas para a formação doutrināria e para um aprofundamento sobre os "problemas sociais" de militantes, es pecialmente femininas, do movimento catôlico, a partir de um contato direto com o ambiente operärio. Estā voltado para uma ação de levantamento moral da família operäria, atuando prefe rencialmente com mulheres e crianças. Atravês de uma ação individualizadora junto às "massas atomizadas social e moralmente" busca estabelecer um contraponto às influências anarco-sin dicalistas no proletariado urbano.

- Serviço Social figura aos militantes desses movimentos como uma alternativa profissionalizante às suas atividades de apostolado social, num momento de profundas transformações sociais e políticas. A Ação Social e a Ação Cá tólica (39) logo tornam-se uma das fontes preferenciais de re crutamento desses profissionais.

(38) Associações Assistenciais e do militantismo católico constituem $\overline{a s}$ bases organizacionais e humanas mais importantes para a emergência da profissão no Brasil. Entre elas pode-se citar a Associação das Se nhoras Brasileiras, fundada em 1922 no Rio de Janeiro e a Liga das Senhōo ras Catôlicas, criada em 1923 , em São Paulo. Em 1932 é fundado do Centrō de Estudos e Ação Social, entidade feminina, que toma a iniciativa da criação da primeira Escola de Serviço Social, em São Paulo no ano de 1936, hoje Faculdade de Serviço Social da PUC-SP.

(39) "A Ação Catôlica assinala o início de una nova época na histó ria da religião: quando ela de concepção totalitäria (no duplo sentido: de que era uma concepção total do mundo, de uma sociedade no sentido to ta1) torna-se parcial (tambem no duplo sentido) e deve possuir un partido prôprio... A Ação catôlica representa a reação contra a apostasia das. amplas massas, impotente, isto e, contra a superaçäo de uma concepção re Iigiosa do mundo. Nâo ê mais a Igreja quem determina o terreno e os meios de luta; ao conträrio, ela deve aceitar o terreno que lhe impõem os adversârios ou a indiferença e servir-se de armas tomadas de emprêsti mo de seus adversärios (a organização polîtica das massas). A Igreja es tâ, portanto, na defensiva, perdeu a autonomia dos movimentos e a inicía tiva, não ê mais una força ideolôgica mmdial, mas uma força subalterna... Cristopolti reconhece que a Ação Ca tólica ê uma inovação e, não co 
A profissão não se caracteriza apenas como no va forma de exercer a caridade, mas como forma de intervenção ideológica na vida da classe trabalhadora, com base na atividade assistencial e cujos efeitos são essencialmente políticos: o enquadramento dos trabalhadores às relações sociais vigentes, reforçando a mútua colaboração entre capital e trabalho.

Diferenciado da caridade tradicional, encarada como mera reprodutora da pobreza, o Serviço Social propõe uma ação educativa junto à família trabalhadora, numa linha não apenas curativa, mas preventiva dos problemas sociais. Distin gue-se, tambēm, da assistência pública, enquanto esta produz respostas não diferenciadas aos "problemas sociais", desconhe cendo a singularidade e particularidade dos individuos. O Se $\underline{r}$ viço Social atuando através de entidades filatrópicas priva das e atravês do Estado, orienta-se para uma individualização da proteção legal entendida como assistência educativa adapta da aos problemas individuais. Desconhecendo o caräter de clas se dos antagonismos sociais, os efeitos desses antagonismos são considerados motivos relevantes para um tratamento sócioeducativo da "clientela", tratamento esse de cunho doutriná.rio e moralizador, amplamente aurido no senso comum da classe de origem desses profissionais. O Serviço Social se propõe, ainda, a uma ação organizativa junto a população trabalhadora, dentro do programa de militância catôlica, fazendo frente às iniciativas provenientes de lideranças operärias que não ade rem ao associativismo católico.

mo dizem as encíclicas papais una atividade que sempre existiu desde o têmpo dos apóstolos. Ela è uma atividade estreitamente ligada, como reação, a o iluminismo francês e ao liberalismo, etc., e a atividade dos Estados modernos pela separação da Igreja, isto ê, à reforma intelectual e moral bem mais radical, para as classes dirigentes, que a Reforma Protes tante; $\vec{e}$ a atividade Católica que começa a configurar depois de 1848 , do fim da Restauração e da Santa Aliança. A Gransci. Maquiavel, a Política e o Estado Moderno, op.cit., p. $280,281,283$, respectivamente. 
Esses elementos, sinteticamente colocados em relevo, permitem subsidiar a afirmativa de que o serviço Social emerge como uma atividade com bases mais doutrivāias que cientificas, no bojo de um movimento de cunho reformista-conservador. O processo de secularização e de ampliação do suporte técnico-científico da profissão -- que se dá com o de senvolvimento das escolas (depois faculdades) especializadas no ensino de Serviço Social -- ocorre sob a influência dos progressos alcançados pelas Ciências Sociais, nos marcos do pensamento conservador, especialmente de sua vertente empiricista norte-americana. Este universo intelectual, ao invés de produzir rupturas profundas com as tendências pragmatistas da profissão as reforçam e atualizam. O Serviço Social mantēm seu carāter técnico-instrumental voltado para uma ação educativa e organizativa junto ao proletariado urbano, articulando na justificativa dessa ação o discurso humanista, calcado na filosobia aristotélico-tomista aos principios da teoria da mo dernização presente nas ciências Sociais. Esse arranjo teörico-doutrinário, oferece ao profissional um suporte técnicocientífico, ao mesmo tempo em que preserva o caräter de uma profissão "especial", voltada para os elevados ideais de "se $\underline{r}$ viço ao Homem".

A fundamentação dessas afirmativas supōe retomar algumas características do pensamento conservador e sua influência na anâlise sociológica.

0 conservadorismo moderno (40), implicando numa forma peculiar de pensamento e de experiência prätica, é

(40) As considerações sobre o pensamento conservador e sua presença nas Ciencias Sociais têm por base as anälises de: R. Nisbet. La Forrinación del Pensamiento Sociolôgico. Buenos Aires, Anorrortu, Vol. I, 1969; R. Nisbet. "Conservadorismo e Sociologia" In: J.S. Martins. Introdução Crítica à Sociologia Rural. São Paulo, Hucitèc, 1980, p. 62-67; K. Mañnheim. Ensayos de Sociologia y Psicologia Social. Mexico. Fondo de Cultu ra Economica, 1963, Cap. II "El Pensamiento Conservador", p. 84-183: K. Mannheim. Ideologia e Utopia. Rio de Janeiro, Zahar, 3a. ed., 1976; H. 
fruto de uma situação histốrico-social específica: a socieda de de classes em que a burguesia emerge como protagonista do mundo capitalista. E este, segundo Mannheim, o ambiente socio lógico do conservadorismo moderno, isto é, do tradicionalismo feito consciente, como um contra-movimento, oponente históri co das tendências da ilustração. (41) Reage ao racionalismo, ao pensamento a base do câlculo, necessârio a universalizaçäo das relações de troca que se impõe, quando a mercadoria tor na-se a mediadora por excelência das relações sociais e o lucro o centro motor da sociedade capitalista.

A fonte de inspiração do pensamento conservador provêm de um modo de vida do passado, o qual ê resgatado e proposto como uma ótica de interpretar o presente e como conteúdo de um programa viāvel para a sociedade capitalista.

Lefbvre. De 1o Rural a 1o Urbano. Barcelona, Ed. Peninsula, 1974, cap. I."Problemas de Socíologia RuraT", p. 19-38 e J.S. Martins. "As Coisas no Lugar" (Da Ambiguidade à Dualidade na Reflexão Sociológica sobre a Ci dade-Campo). In: Sobre o Modo Capitalista de Pensar, op. cit., p. 4382.

(41) Mannheim, utilizando a técnica de anälise de significações, com preende o-conservadorismo como um estilo de pensamento, um modo de conhē cer e experimentar o mundo, que tem por base o destino dos grupos e clas ses sociais que são os seus portadores. 0 estilo de pensamento expressa, portanto, uma intenção bâsica, decorrente de um modo de vida. Enquanto ao modo de vida capitalista corresponderia o estilo de pensamento racionalista, o conservadorismo expressaria um modo de vida pré-capitalista, subsistindo como contra-corrente junto a camadas sociais que permaneceram "fora" do processo capitalista de racionalização: estratos carmoneses, grupos pequeno-burgueses descendentes do artesanato e, ainda, nas tradiçõos aristocráticas da nobreza. As relações irracionais entre os ho mens são levadas para a periferia da vida dos indivíduos, em suas esferas intimas e privadas e para os grupos que vivem na periferia da nova sociedade. Ver. K. Mannheim. Ensayos de Sociologia y Psicologia Social, op. cit., J.M.S. Martins, na obra supra citada, elaborada uma crítica desse esquema analítico, a qual é incorporada no presente texto. Ver: J.S. Martins. "As Coisas no Lugar...", op. cit.. 
"A Comunidade se levanta contra a sociedade (para empre gar a terminologia de Tonnies), a família contra o con trato, a certeza intuitiva contra a razão, a experiência espiritual contra a experiência material. Todos es tes fatores, parcialmente ocultos na base mesma da vidā cotidiana, são descobertos subitamente pela reflexão e se luta a favor deles". (42)

Nesse sentido os conservadores são "profetas do passado". (43) Porēm, a exaltação deliberada de formas de vida que jă foram historicamente dominantes, vistas como propostas vâlidas para a organização da sociedade presente, é elaborada teoricamente atravês de categorias típicas do racio nalismo capitalista. (44) Instaura-se, assim, uma tensão entre a concepção e programas que veicula e o procedimento analítico através do qual são propostos.

O que se constata è um "rapto ideológico" de noções que são reinterpretadas no seu significado original e propostas como "vâlidas" para se compreender e agir em um contexto histôrico diferenciado daquele no qual emergiram. Po rêm välidas para quem interessa obscurecer as contradições próprias da sociedade capitalista, interpretando-a de maneira que a nível analítico, sobressaia apenas o que favoreça sua própria coesão e reprodução, encobrindo as desigualdades fundamentais que nela sằo produzidas.

(42) K. Mannheim. 'Ensayos...", op. cit., p. 100-101.

(43) R. Nisbet. "La Formación del Pensamiento Sociolögico", op. cit.., p. 26 .

(44) "O romantismo tratou de resgatar as forças irracionais reprimi das, lutou por elas, porém não advertiu que o mero fato de prestar = Thes una atenção deliberada significa uma racionalização inevitâvel. 0 romantismo realizou uma racionalização que a ilustraçăo burguesa nunca havia feito... Quando o clima geral é racionalista até os elementos irra cionais tem que ser submetidos à reflexão racional para serem entendidos. Assim o romantismo pode ser interpretado como reconpilação ou um resgate de todas as atitudes e modos de vida definitivamente religiosos, reprimi dos pela marcha do racionalismo capitalista, porẻm uma recompilação $\overline{\mathrm{e}}$ uma conservação no plano da reflexáo". K. Mannheim, idem, p. 101 .

(45) H. Lefebvre. De 10 Rural a 10 Urbano, op. cit.. 
Atravês desse mecanismo, o pensamento conserva dor deixa de se antagonizar com o capitalismo. Aquela tensão referida - entre noções e idéias oriundas do passado, nas ressú citadas intencional e racionalmente como ideologicamente vāi das para responder as necessidades de explicação da pröpria sociedade capitalista,...- permite que ele seja articulado às intenções básicas da burguesia, isto é, uma forma de agir e de pensar a sociedade a partir da perspectiva dessa classe. Martins (46) analisando a ambiguidade presente no pensamento conservador, sustenta que racionalismo e conservadorismo são duas maneiras de viver e de ver a sociedade, portanto dois pensamentos, mas integrados a um único estilo de pensamento, exprimindo um modo de vida: o da sociedade capitalista.

Assim o conservadorismo não significa apenas uma continuidade e persistência no tempo de um conjunto de idéias constitutivas da herança intelectual europẻia do Sécu10 XIX, mas de idéias que, reinterpretadas, se transmutam em uma ótica de explicação e em projetos de ação favorecedores da manutenção da ordem capitalista. Isto possibilita que o pensamento conservador e racional possam ser compatibiliza dos, apesar de suas diferenças, dentro de um mesmo projeto de classe para a sociedade.

Essa anālise não exclui a importância de se apreender algumas peculiaridades do pensamento conservador e de sua presença nas Ciências Sociais contemporâneas, para a compreensão do Serviço Social, que nasce e se desenvolve embe bido em idéias conservadoras, incorporando as ambiguidades do reformismo conservador.

(46) J.S. Martins. "As Coisas no Lugar...", op. cit.. 
Dentre as características do pensamento conser vador, (47) destaca-se sua vocação pelo passado, terreno germinativo da inspiração para a interpretação do presente. 0 passado é experimentado como virtualmente presente. A socieda de tende a ser apreendida como constitutiva de entidades orgânicas, funcionalmente articuladas, cujo modelo é a família e a corporação. Os pequenos grupos são tidos como fonte das relações interpessoais, da sociabilidade e da moralidade. Valoriza os elementos sagrados, irracionais, não utilitärios da existência em contraposição ao primado da razão. E da tradi ção e dos costumes de onde deriva a legitimidade da autoridade. O conservador pensa à base do "nôs", encarando o indivíduo não como uma partícula isolada e atomizada na sociedade, mas como parte de unidades mais amplas, dos grupos sociais bäsi cos. Reage a toda igualdade externa, que desconheça as particularidades individuais. A individualidade $\bar{e}$, aí, radicaliza da: (48) os homens são seres essencialmente desiguais, porquanto particulares. A liberdade é subjetivada: consiste na ha bilidade de cada indivíduo desenvolver-se de acordo com as possibilidades e limitações de sua personalidade, com o nücleo de seu ser e o ser mais profundo do homem ê sua individualidade e sua essencia moral. Assim a liberdade $\vec{e}$ levada, restritivamente, a esfera privada e subjetiva da vida enquan to as relações "externas" e sociais devem ser subordinadas aos princî́pios da ordem, da hierarquia e da disciplina.

(47) Ver: R. Nisbet. "Conservadorismo e Sociologia", op. cit.; e K. Mannheim. Ensayos de Sociologia..., op. cit..

(48) "O reformísmo conservador consiste na substituição de fatores individuais por outros fatores individuais ("melhoras"); e reformismo progressista tende a suprimir un fato indesejâve1, reformando todo o mm do circundante que torna possivel sua existência. Assim, pois, o refor = mismo progressista tende a atacar o sistena no seu conjumto, enquanto o reformi smo conservador ataca detalhes particulares". K. Mannheim. Ensayos de Sociologia..., op. cit., p. 116. 
o conservador reage aos princípios universali zantes e abstratos do pensamento dedutivo: seu pensamento ten de a aderir aos contornos imediatos da situação com que se de fronta valorizando os detalhes, os dados qualitativos, os casos particulares, em detrimento da apreensão da estrutura da sociedade. A mentalidade conservadora não possui predisposição para teorizar. Sendo a organização da sociedade vista como fruto de uma ordenação natural do mundo, o conhecimento vi sa um controle prâtico das situações presentes. O conservador elabora seu pensamento como reação à circunstâncias histôricas e idẻias que se afiguram ameaçadoras à sua influência na sociedade. 0 conservadorismo torna-se consciente, no plano da reflexão, como defesa, decorrente da necessidade de armar-se ideologicamente para enfrentar o embate das forças oponentes.

Sem qualquer pretensão exaustiva, estes são a 1 guns traços que conferem um perfil ao conservadorismo, o qual adquire matizes específicas nas diversas correntes internas do próprio pensamento conservador e frente à situações históricas particulares nas quais se expressa.

Nisbet, afirmando ser o conservadorismo moder no fruto da Revolução Francesa e da Revolução Industrial ana lisa sua influência no pensamento sociológico a partir do que denomina idéias elementos da sociologia, (49) das quais a noção de comunidade é a de maior alcance e a mais fundamental:

(49) Nisbet elabora o estudo do pensamento sociológico a partir das idéias elementos, que formam, no seu entender, os elementos constitutivos da sociologia, a "medula" dessa disciplina científica, persistindo desde a época clässica da Sociologia moderna até o momento presente. São elas: comunidade, autoridade, status, sagrado e alienação. Cada uma destas idéias está associada a uma antítese, da qual deriva grande parte de sua significação: comunidade-sociedade, autoridade-poder, status-classe, sagrado-secular, alienação-progresso. 0 autor desenvolve sua análise a partir da hipötese de que o ethos do individualismo (indivíduo natural) e a visão da ordem baseada em interesses racionais não esgota o pensamen to do Século XIX. Verifica-se, aî, a reação do tradicionalismo contra $\bar{a}$ razão analítica, do commalismo contra o individualismo, do não racional contra o puramente racional, como resposta intelectual a situação da crí 
"Quando digo commidade, quero significar algo que uI trapassa a mera comunidade local. A palavra, tal como a encontramos em grande parte dos pensadores dos ü1timos séculos, abarca todas as formas de relaçőes caracteriza das por alto grau de intimidade pessoal, profundidade emocional, compromisso moral, coesão social e continuidade no tempo" ( $\underline{50)}$

A comunidade tem sua força proveniente de mot $\underline{i}$ vações mais profundas que o mero interesse racional, na qual - homem é concebido como totalidade, e não a partir dos papéis que desempenha na ordem social. Seu modelo do ponto de vista histórico ê a famîlia. Os laços de comunidade passam a compor a idéia da "boa sociedade", estando na base do conceito do social, tal como é, predominantemente, utilizado pelos sociólogos. (1ㅡ) 0 simbolismo da comunidade torna-se um meio de legitimação das relações sociais, um novo esquema de uto pia.

A noção de comunidade permeia a produção dos autores clâssicós da teoria sociológica: a sociologia, embora se apresente como uma forma secularizada de conhecimento, in

se da êpoca. E nesse processo que emerge o conservadorismo moderno carac terizado pela defesa da tradição social, de origem medieval, dela deri= vando a insistência nos valores supra-mencionados, incorporados pela sociologia moderna, embora esta se afirme como una forma secularizada de conhecimento. 0 conservadorismo reage contra o igualitarismo, e o poder centralizado no povo, contra a substituição de valores sociais não racio nais por normas impessoais e efêmeras de contrato-utilidade, contra a dé cadência da autoridade política, social e religiosa; reage, ainda à perda da liberdade medieval e a decadência da cultura pela sua difusão junto as massas. Ver: R. Nisbet. La Formación del Pensamiento Sociológico, op. cit.. Ver, também, a análise crítíca dessa perspectiva em J.S. Martins. "As Coisas no Lugar...", op. cit. p. $71-72$.

(50) R. Nisbet. La Fornación del Pensamiento Sociológico, op. cit.,

(51) "A sociologia, mais do que qualquer outra disciplina, deste sê culo, deu primazia ao conceito do social. O ponto que queremos insistī $\bar{e}$, sem düvida, que o referente ao social foi quase que invariavelmente o commal. "Communitas" e não "societas" (com suas conotações impessoais) é a verdadeira fonte etmológica da palavra "social", tal como a emprega o sociólogo em seus estudos sobre o parentesco, a econonia, o sistema pü blico." R. Nisbet. idem, p. 82. 
corpora o compromisso com o conservadorismo. (52) Nisbet assu me a hipótese de que as preocupações hoje vigentes na sociolo gia norte-americana com a ordem social, ajustamento/desajusta mento social, integração/desintegração grupal, com a natureza da personalidade estão enraizadas na tradição conservadora do pensamento europeu do Século XIX, mais do que no sistema libe ral, geralmente tomado como o fundamento da sociologia mode $\underline{r}$ na. (53)

O Serviço Social nasce e se desenvolve na órbi ta desse universo teórico. Passa da influência do pensamento conservador europeu, franco-belga, nos seus primórdios, para a sociologia conservadora norte-americana, a partir dos anos quarenta. Incorpora a noção de comunidade como matriz analít ca da sociedade capitalista e como projeto norteador da ação profissional. Porém a comunidade é erigida como ótica de interpretação da sociedade capitalista, quando jâ deixou de ter contrapartida histórica, isto $\vec{e}$, quando a sociedade encontrase estruturada não mais segundo os princípios das relações co munitärias, mas conforme os parâmetros da racionalidade burguesa, da reprodução capitalista do capital.

(52) Nisbet demonstra como a noção de comunidade estā presente na teoria sociológica: em Comte, a sociedade é considerada a commidade "in extenso", ser supremo do culto positivista; a commidade como utopia estă expressa no seu conceito de comunidade moral (commidade perdida é co munidade que tem que ser ganha, é o tema que orienta tanto sua Estäticá como sua Dinâmica social). Le Play introđuz o estudo empírico substantivo da commidade, através do estudo da família da classe trabalhadora (Os Trabalhadores Europeus, de 1855). Em Tơnnies a commidade aparece co mo tipologia, no "gemeischaft" e "gesellschaft": opõe a noção de comuni=dade (no sentido definido por Nisbet) a sociedade como um tipo de rela ção humana caracterizada por alto grau de individualismo, impessoalidade-, contratualismo, procedente da volição e do puro interesse. A comunidade aparece tambêm, como metodologia em Durkheim, Simmel, e Weber, tornandose instrumento de anälise da conduta reflexiva do ser humano. Ver: $R$. Nisbet. Ia Formación..., op. cit., especialmente cap. III.

(53) R. Nisbet. "Conservadorismo e Sociologia", op. cit. 
0 princípio da solidariedade $\underline{(54)}$ é incorpora da como diretriz ordenacoora das relações sociais, em tensão com seus fundamentos históricos concretos. As relações socials passam a ser vistas invertidamente: a coisificação alienadora das relações que se estabelece no universo da mercadoria são obscurecidas, fazendo reaparecer, na base mesma da sociedade, relaçōes pessoais, solidârias, personalizadas.

Porêm importa destacar que na base desse con servadorismo existe um componente utōpico assimilado pelo Ser viço Social, decorrente desse universo teórico, balizado pela filosofia humanista cristã. A comunidade ressurge aí como uto pia ( $\underline{5}$ ) nos meandros de um reformismo conservador, orientan do a ação profissional.

A comunidade como utopia contém um componente de resistência à organização social da sociedade capitalista, componente este anti-capitalista, por que anti-societário: sua viabilidade histörica é dada pela superação do capitalismo, pela supressão da mediação coisificadora da mercadoria nas re

(54) Ver as anålises de 'J.S. Martins, incorporadas no desenvolvimento dessa reflexão: J.S. Martins. A Imioracão e Crise do Brasil Agrärio, op. cit., especialmente " 0 Camponēs e a Commidade Utōpica", p. 13-28; "Ás Relações de Classe e a Produção Ideológica da Noção de Traba lho" In: Contexto $n^{8}$, São Paulo, Hucitec, maio 1978 , p. 37-53.

(55) Martins, analisando o camponês e a commidade utốpica sustenta a respeito da utopia commitária. 'Enquanto visão de mundo que norteia o relacionamento numa formação social concreta, ela explica integralmente a vida camponesa, estabelecendo os nexos entre os elementos da situação cơno se não fossem referidos a outros componentes da formação capitalista". J.S. Martins. A Imigração e Crise do Brasil Agrärio, op. cit.,p.29. 
lações entre os homens. (56) Segundo Martins, contêm um proje to de vida alternativo que busca efetivar, mas que é desproví do da base histórica, ao desconsiderar a estruturação da prô pria sociedade capitalista. Consequentemente, o que subjetiva mente pode ter um carảter de recusa, è vivido objetivamente como confirmação da ordem vigente.

Enquanto os fundamentos do modo de vida veiculados pela utopia comunitâria são redefinidos pelo capitalismo, essas redefinições não são apreendidas pela consciência dos agentes sociais, que permanece aderida a um modo de vida estranho ao capitalismo. O que se apreende são os efeitos daquela redefinição, os quais se busca neutralizar.

Analisando a sociedade a partir do suporte teó rico da noção de comunidade, do princípio da solidariedade co mo base ordenadora das relações sociais, o Serviço Social alia a este universo teórico um outro elemento: a filosofia social humanista cristã : Ao mesmo tempo, aprimora os procedimentos de intervenção incorporando os progressos do Serviço Social norte-americano no que se refere aos métodos de trabalho com individuos, grupos e comunidades. Ou seja, enquanto os procedimentos de intervenção são progressivamente racionalizados o conteúdo do projeto de ação profissional permanece fundado no reformismo conservador e na base filosófica aristotêlicotomista.

(56) "... intersubjetivamente, a commidade utópica constitui uma forma de resistência, passiva ou não, as rupturas estruturais da socieda de; objetivamente, porém, a utopia comunitäria se insere dinamicamente = nas relações sociais como resistências aos efeitos sociais dessas rupturas. Is to $\hat{e}$, inverte o seu sentido. Alienadamente o camponês formula e desencadeia sua oposição à sociedade capitalista. Essa oposição fundada na utopia commitaria ê anti-capitalista, na medida em que ê anti-societấria, is to ê, na medida em que antagoniza a idêia constitutiva e doninante do sistema que $\vec{e}$ a de sociedade, enquanto contrato, vỉnculo racio nal, fruto da razáo abstrata, que se traduz num querer objetivamente da= do". J.S. Martins. A Imigração e Crise do Brasil Agrärio, op. cit., p. 27-28. 
Este arranjo teórico-doutrinário-operativo per mite que a profissão mantenha o seu carăter missionẩio, atua lizando as marcas de origem e atendendo, concomitantemente, às exigências de tecnificação que the impõem a modernização da sociedade e do Estado. Se isto permite que a proposta profissional se adeque às exigências da ordem burguesa, na consciên cia dos agentes profissionais se instaura uma profunda ambi gllidade: a ação que é desencadeada, subjetivamente, como recu sa aos "excessos de diferenciação social", como forma de ate nuar ou até mesmo de eliminar as injustiças sociais ou como missão a serviço do "homem", se transubstancia objetivamente numa prática que reforça os fundamentos da ordem alienadora, que produz e reproduz as desigualdades sociais. Em outros te $\underline{r}$ mos: os efeitos da ação profissional aparecem como uma nega ção dos propósitos humanistas que a orientam. Torna-se palpá vel a defazagem entre propósitos e resultados da ação, entre teoria e prätiça.

0 pensamento humanitário incorporado pelo Ser viço Social conduz a que a humanização das condições de vida e de trabalho dos segmentos sociais que constituam a "cliente la" atendida pelo profissional seja proposta como objetivo den tro das condições do trabalho alienado, que não são questiona das. Veicula a "ideologia do trabalho" (57) e confirma a con dição do trabalho assalariado, como elemento constitutivo da ordem social:"natural", ao mesmo tempo em que coloca como ob jetivo fazer da prática profissional um instrumento de recó nhecimento da pessoa do trabalhador, enquanto individuo parti cular, enquanto "sujeito". Os efeitos da exploração capitalis ta do trabalho são reconhecidos e transformados em "problemas sociais", justificadores da ação profissional, não se colocan do em questão as razões histôricas daquela exploração. Este

(57) J.S. Martins. "As relações de Classe e a Produção Ideológica da Noção de Trabalho", op. cit. 
esquema de percepção permite conciliar a concepção humanis ta-cristã de vida e a exploração burguesa do trabalho. Aí a exploração das classes é suposta e os esforços passam a se orientar no sentido de fazer com que burgues e operário sejam solidários, dado que sua condição comum de pertencerem a uma mesma "comunidade produtiva" e também de "seres humanos" sobrepuja: qualquer diferença social. Como as bases da organi zação social são tidas como dadas, não sendo questionadas em suas raízes, a solução entrevista está a nível da heforma do homem dentro da sociedade, para o que deve contribuir o Serví ço Social.

Assim, essas representações que orientam o con teûdo de um programa para a sociedade, embora preservem seu conteúdo utópico, não se antagonizam com a ordem capitalista, passando a serem mobilizadas e incentivadas pela própria burgue sia e pelo Estado.

As características ressaltadas do pensamento conservador, encontram-se profundamente enraizadas no discurso e na prática profissional, tornando-se parte integrante da configuração da profissão. Além da noção de comunidade jā salientada, merece destaque a ênfase na formação social, moral e intelectual da familia, considerada como cêlula bäsica da sociedade. Trata-se de um trabalho "educativo" junto à família operária, especialmente junto daqueles mais carentes que têm acesso aos equipamentos sócio-assistenciais, tendo em vista o reforço do núcleo familiar e a integração de seus membros à sociedade. E na histöria familiar que são buscados os elementos explicativos de comportamentos individuais "anômalos" ou "desviantes" de um padrão tido como "normal". A famîlia, como grupo social bâsico, é erigida como núcleo do trabalho profissional e como referência para a apreensão da vida em sociedade, em contrapartida às classes sociais. 
A individualização dos "casos sociais", em detri mento do reconhecimento da situação social comum vivida pelos segmentos sociais que constituem a "clientela" do Serviço Social, ê outra característica marcante dessa atividade profissional. Os indivíduos são encarados como seres unicos e parti culares, com potencialidades a serem desenvolvidas, desde que estimuladas, cuja dignidade de seres humanos e cuja liberdade merecem o respeito do profissional. Porëm, tais características tendem a ser apreendidas desvinculadas de suas bases mate riais, is to é, subjetivadas e autonomizadas da situação social de vida dos "clientes", transformando-se em princípios e postulados universalizantes orientadores da ação profissional. (효)

Outro fator a considerar refere-se à teridência empirista e pragmatista que vem marcando essa prâtica profissional. Ganham relevo as atividades de pesquisa e classificação da população cliente que sempre constaram como uma das atribuições básicas do Assistente Social, como pressuposto pa ra a concessão de auxílios e benefícios sociais. Apenas o conhecimento empírico, mesmo que circunscrito à área sob intervenção, viabilizaria aquela intervenção. Essa atividade de pesquisa, realizada muitas vezes atravēs da visita domiciliar, busca na realidade identificar os elementos que compõem o mo-

(58) Dentre os postulados êticos e metafísicos para a ação do Serviço Social tem-se: "a) postulado da dignidade da pessoa himana: que se entende corno uma concepção do ser humano numa posiçâo de eminência ontológica na orden universal e ao qual todas as coisas devem estar referidas; postulado da sociabilidade essencial da pessoa humana: que é o reconhecimento de dimensao intrínseca a natureza humana, e, em decorrência do que se afirma o direito da pessoa humana encontrar, na sociedade, as condições para sua auto-realização; c) postulado da perfectibilidade humana: compreende-se como o reconhecimento de que o homem $\bar{e}$, na ordem ontolōgīca, um ser que se auto-realiza no plano da historicidade humana, em decorrência do que se admite a capacidade e potencialidades naturais dos indivíduos, grupos e commidades e populaçōes para progrediren e se auto promoverem"."Documento de Arax"." Debates Sociais, n? $n^{\circ}$, ano III, maio 1967, p. 9 . 
do de vida e de existência do proletariado, o que possibilita uma hierarquização dos riscos sociais a que estão sujeitos os indivíduos, famílias e grupos sociais e a consequente delimitação de uma população alvo preferencial a ser atingida pelos programas assistenciais e pelo próprio Serviço Social. A hierarquização dos riscos obedece a uma classificação baseada nu ma escala de "tipos de desajustamentos bio-psico-sociais" que estigmatiza e etiqueta a população, informando aos organismos institucionais a atitude a assumir frente a cada grupo, a qual pode oscilar de medidas paliativas rotineiras à multipli cidade de iniciativas de intervenção e controle.

Se o Serviço Social surge no seio do movimento católico, o processo de profissionalização e legitimação da profissão encontra-se estreitamente articulado à expansão das grandes instituições söcio-assistenciais estatais, pāra-estatais e autárquicas que surgem, especialmente, na dêcada de quarenta. (59). A criação dessas grandes instituições tem como pano de fundo um período marcado pelo aprofundamento do modeto corporativista de Estado e por uma política econômica favo recedora da industrialização. A expansão do proletariado urba no, reforçada pela migração interna, cria a necessidade política de controlar e absorver esse setor. Nesse processo, o Es tado tem que incorporar, necessariamente, parte das reivindicações populares, ampliando a base de reconhecimento legal da cidadania do proletariado e dos direitos sociais dai decorren tes, atravês de uma legislação social e sindical profícuas no período.

E nesse contexto que emergem as grandes instituições assistenciais e previdenciärias como parte dos esfor ços reformadores do Estado para responder as pressões das novas forças sociais urbanas. O Estado passa não só a intervir

(59) Surgem, nesse período, o Conselho Nacional de Serviço Social (1938), a Legião Brasileira de Assistência (1942), o Serviço Nacional de Aprendizagem Industrial (1942) e o Serviço Social da Indústria (1946). 
na regulamentação da força de trabalho, mas tambêm no estabelecimento e controle de uma politica assistencial intimamente vinculada às organizações representativas das "classes produtoras". Estas, progressivamente, confirmam sua adesão à política de controle social da ditadura varguista, ao perceberem que a "paz social" imposta atravês de uma legislação simultaneamente paternalista e repressiva reverte em rentabilidade $\underline{e}$ conômica da empresa.

O surgimento dessas instituições representam uma enorme amoliação do mercado de trabalho para a profissão, tornando o Serviço Social uma atividade institucionalizada e legitimada pelo Estado e pelo conjunto dominante. Se era o ca râter de missão de apostolado social e a origem de classe dos "pioneiros" que conferiam legitimidade à intervenção do profissional, agora essa legitimidade será derivada do mandato institucional, confiado ao Assistente Social direta ou indire tamente pelo Estado. A vinculação institucional altera, ao mesmo tempo, a clientela do Serviço Social: de pequenos seg mentos da população pobre em geral, atingida ocásionalmente pelas obras sociais confessionais, seu püblico se concentrará em amplos setores do proletariado, alvo principal das politicas assistenciais implementadas pelas instituições. Este pro cesso constitui, ainda, a consolidação da profissionalização do Assistente Social, que se torna categoria assalariada, es tendendo-se seu recrutamento junto aos setores mẻdios. Em su ma o Serviço Social deixa de ser um instrumento de distribuição da caridade privada das classes dominantes, para se trans formar prioritariamente, em uma das engrenagens de execução da política social do Estado e setores empresariais.

Nesse processo de institucionalização a profis são passa a ser crescentemente incorporada aos programas que concretizam as políticas sociais do desenvolvimentismo popu- 
lista, (무) que após a Segunda Guerra torna-se a ideologia do minante. Esse processar permitirâ, tambëm, ao Serviço Social -- da mesma forma que o permitiu sua cooptação pelo Estado -manter com algumas adequações as características básicas da prática e do pensamento conservador, que o marcam desde a sua origem.

A atualização da herança conservadora, aparece de forma mais destacada no "pōs-64" e informa as respostas da das por parcela majoritâria da categoria profissiopal às novas demandas que the são apresentadas no capitalismo mono lista. Essa atualização incide em mudanças no discurso, nos métodos de ação e no projeto de prätica profissional às novas estratégias de controle e repressão da classe trabalhadora, efetivadas pelo Estado e pelo grande capital, para atender às exigências da política de desenvolvimento com segurança. Tra duz-se numa modernização da instituição serviço social. De um lado, tem-se a:preocupação com o aperfeiçoamento do instrumen tal operativo, com as metodologias de ação, com a busca de padrões de eficiência, sofisticação de modelos de anālise, dia gnôstico e planejamento, enfim uma tecnificação da ação profissional. (61) Esta é acompanhada de uma crescente burocrati zação das atividades institucionais, resultantes das reformas administrativas que atingem o aparelho de Estado, as grandes instituições assistenciais e as empresas.

(60) Ver entre outros: Anais do II Congresso Brasileiro de Serviço So cial. Rio de Janeiro, CBCISS, 1961 e S.B. Ammann. Ideologia e Desenvolvimento de Commidade no Brasil, São Paulo, Cortez Ed., 1980.

61) Un dos exemplos mais expressivos desta modemizaçäo são os dois Seminarios de Teorização do Serviço Social, promovidos pelo CBCISS com 0 apoio de ôrgãos governamentais e patronais, em Araxâ (1967) e Terezôpolis (1970), que tiveram ampla repercussão nacional e intemacional, no meio dos Assistentes Sociais. Os resultados desses eventos encontram-se expres sos no "Documento de Araxâ". Revista Debates Sociais, $n^{\circ} 4$, ano III, Riō de Janeiro, CBCISS, maio 1967; e no Docamento de Terezopolis - Metodolo gia do Serviço Social". Revista Debates Sociais. Suplemento n 4, 5a. ed., Rio de Janeiro, CBCISS, set. 1978. 
De outro lado, verifica-se uma maior aproximação do discurso profissional aos fundamentos da teoria da modernização presente nas Ciências Sociais. (62) Expressa-se nu ma prática profissional, numa perspectiva voltada para mudan ças de hâbitos, atitudes e comportamentos do trabalhador tendo em vista sua adequação aos novos rítmos de desenvolvimento. Es te tipo de suporte científico mantem-se, porêm, articulado à metafísica aristotêlico-tomista que informa a base filosóf ca da visão de homem e de sociedade, $\underline{(63)}$ ○ que permite a pro fissão atualizar seu caräter missionărio, preservando o seu componente utópico.

Face ao clima repressivo e autoritário, decorrente das mudanças políticas da década de sessenta, os Assistentes Sociais refugiam-se, cada vez mais, em uma discussão dos elementos que supostamente conferem um perfil peculiar à profissão; seu objeto, objetivos, métodos e procedimentos de intervenção, sendo aí privilegiada a ênfase na metodologia

(62) Sobre a teoria da modernização ver, entre outros: G. Germani. Po lítica y Sociedad em una Epoca de Transición. Buenos Aires, Ed. Paidos, 1962, E.E. Hagen. On the Theory of Socral Change. Homewood, Dorsey Press, 1962; D. Lerner. The Passin of Tradicional Society: Modernizing the Middle East. New York, The Free Press, 1958; L. Pinheiro Machado. "Alcances e Limites da Teoria da Modernização". Revista de Administração de Empresas, $n^{\circ} 2$, vol. 10. Rio de Janeiro, Fundaçao Getulío Vargas, jul-set 1970, p. 169-192. F.H. Cardoso e E. Faletto. Dependência e Desenvolvimento na América Latina. Rio de Janeiro, Zahar, 1973; 0. Ianni. Sociologia da Sociologia Latino-Americana. Rio de Janeiro, Ed. Civilização Brasileira, 1971.

(63) Ana Augusta de Almeida comentando o Documento de Araxâ considera que a linguagem filosófico-científica empregada no documento revela as co locações do chamado "modelo brasileiro no Serviço Social" em dois mundō̄ culturais: "o do pensamento metafísico, aristotêlico-tomista, que informa os conceitos, a logica das categorias; o da intervenção, construída em termos teôrico-científicos, numa abordagem estrutural (sic) inserida num contexto político-econômico com instrumental emprestado das Ciências Sociais" A.A. Almeida "O movimento de Reconceituação slo Brasil. Perspectiva e Consciência". Debates Sociais, $n^{\circledR}$ 21, Rio de Janeiro, CBCISS, 1975, p. $43-53$. 
profissional. (64) A tecnificação possibilita uma eufemização do paternalismo autoritärio presente na ação profissional, de senvolvendo métodos de imposição mais sutis que preconizam a "participação" do "cliente" nas decisões que lhe dizem respe to; participação esta, que não prescinde do respeito à hierar quia (65) e à delimitação precisa de campos entre o técnico e o "paciente". (66)

Instaura-se, ao mesmo tempo, uma forte tendên cia, presente em segmentos específicos do meio profissional, à psicologização das relaçōes sociais, (67) que privilegia problemas de desintegração e desadaptação social e funcional, isto é, problemas relacionais, que necessitam ser 'tratados através do diālogo. Esta ênfase leva à priorização de todas as necessidades que se situam além das carências objetivas e materiais do cliente, isto é, problemas existenciais que devem ser tratados profissionalmente. As exigências de sobrevivência são tidảs como demandas secundārias para uma profissão

(64) 'Na medida em que se fechava o caminho para una crítica efetiva da viđa social, o Serviço Social Brasileiro iniciou a crítica de suas pró prias modalidades de intervenção. Em outras palavras: impossibilitado de questionar-se socialmente, o Serviço Social brasileiro se questionou metodologicamente. As preocupações sobre a função social do Serviço Social, a analise de seus valores ideológicos, o tratamento de suas implicações sócio-políticas, tudo isto foi substituído pelo excessivo cuidado com o instrumental que deveria ser utilizado no exercício profissional... 0 fetiche da teoria metodológica invade os círculos institucionalizados, transfere-se aos seminários profissionais e estende-se às atividades docentes... As construçōes teóricas se desenvolvem em instâncias de abstração tomadas diretamente do pensamento estrutural-funcional ou do discurso lógico do neo-positivismo. J. P. Netto. "La Crisis del Processo de Reconceptualizaciōn del Servicio Social". In: N. Alayôn et alii. Desafio al. Servicio Social. Buenos Aires, Hunanistas, 1975.

(65) Ver: D. Pignon e J. Querzola. "Ditadura e Democracia na Produçäo" e A. Gorz. "Técnica, Técnicos e Luta de Classe". In: A Grrz. Crítica da Divisão do Trabalho, op, cit., p. 91-140 e 211-248, respectivamente.

(66) J.A. Guilhon de Albuquerque. A Metäfora da Desordem. Rio de Janeiro, Paz e Terra, 1977.

(67) J. Verdès-Leroux. Le Travail Social, op. cit. Ver, especialmente cap. "Técnica e Espiritualidade no Confronto de Classe", p. 82-101. 
que procura ultrapassar o estígma assistencialista. Os proble mas materiais tendem a ser espiritualizados, transformados em dificuldades subjetivas, de adaptação social: didifuldades do individuo beneficiar-se dos recursos e oportunidades que a sociedade the oferece. O cliente não deve ser visto como um "pobre", mas como uma "pessoa" e, todos os cidadãos são clien tes potenciais do Serviço Social, visto que todos podem apre sentar problemas relacionais e afetivos que necessitam orientação psico-social. Instaura-se, assim, uma tendência trans classista na consideração da clientela do Serviço Social, em choque com sua realidade efetiva, constituída dos segmentos mais pauperizados da classe trabalhadora. A psicologização das relações sociais permite preservar o julgamento moral da clientela, agora encoberto por uma aparência científica que tem por base rudimentos da psicanálise.

Subjacente a esse processo de atualização da herança conservadora do Serviço Social, nota-se a permanência e reforço de dois elementos que marcam, profundamente, o sen tido da prätica profissional e as percepções que os agentes têm da mesma. De um lado, tem-se a transformação de questões que são de economia política em problemas assistenciais, (요) paralelamente à transformação de direito e usufruto de con quistas sociais do proletariado, em concessão de benefícios; benefícios esses que nunca são vistos como direitos, mas como expressão de carências, "faltas", "desvios de personalidade", etc.. Por outro lado, reforçam-se mecanismos que dificultam a apreensão dos reais efeitos da ação profissional. A reificação dos métodos e técnicas da intervenção, a burocratização das atividades, a psicologização das relações sociais, a absorção de uma terminologia mais adequada à estratégia de crescimento eco nômico acelerado são fatores, entre outros, que contribuem para

(68) 0. Ianni. Pronunciamento, como membro de Banca Examinadora da Tese đe Mestrado de Maria Luiza de Souza, PUC-SP, 18 de agosto de 1978. 
encobrir na consciência do profissional as reais implicações de sua prätica. Aprofunda-se a distância entre as pretensões teōricas dos profissionais e os efeitos de sua intervenção, enquanto agentes das políticas sociais do Estado. Nesta perspectiva, a resolução da "crise da profissão" reduz-se, constantemente, a um maior aperfeiçoamento técnico-instrumental; vincula-se ao reconhecimento, pelas instâncias responsáveis pela elaboração e implementação das políticas sociais, das po tencialidades daquele instrumental, para atuar sobre a "questão social". Essa perspectiva implica na reafirmação e aprofundamento da subordinação do Serviço Social às necessidades da política de dominação e controle das classes subordinadas emanadas do Estado, e portanto, na negação de qualquer veleidade crítica que ultrapasse os limites do sistema. Resume-se, na prâtica, à procura sempre renovada de apresentar-se como alternativa confiảvel de enfrentamento da "questão social", ampliando o campo de ação profissional e a legitimidade dessa intervenção junto às instâncias mandatārias, aparecendo, ainda, em nível secundârio, a preocupação em tornā-la mais aceitävel pela população cliente.

\subsubsection{A Ruptura com a Herança Conservadora}

A revisão da trajetöria histórica do Serviço Social no Brasil aponta, como sugerido anteriormente, para a prevalência de um comportamento essencialmente conservador. No ta-se, a partir dos registros disponíveis, que ê apenas nos fins dos anos cinquenta e início da década seguinte, que se fa zem ouvir as primeiras manifestações no meio profissional que se posicionam contra o "status quo" e contestam a prātica ins tìtucional vigente. Esses quostionamentos emergem numa conjun tura marcada por uma situação de crise e intensa efervescência po lítica no continente, no quadro do colapso do populismo e de uma reorientação tảtica do imperialismo em relação às socieda des dependentes. Por outro lado, é nesse mesmo quadro conjuntural que o meio profissional começa a ampliar-se e moderni- 
zar-se com rapidez face à multiplicação das Escolas especiali zadas e a demanda objetiva do Estado e das empresas.

No plano político interno essas manifestações irão coincidir com a intensificação da radicalização política que marca o período final do pacto populista e que tem por desfecho uma expressiva mudança na correlação de forças com o movimento de 1964. Nesse panorama o meio profissional passa a ser pressionado a posicionar-se face o debate que atravessa a sociedade, que naquele momento pode ser sintetizado na ques tão das "reformas de base", entre as perspectivas de modernização e das reformas estruturais.

0 crescimento da organização dos trabalhadores urbanos e rurais se faz acompanhar de um processo de politiza ção dos setores médios. Assume expressão uma "esquerda cristã", que passa a influenciar contingentes maiores de Assistentes Sociais, seja através das Escolas, do movimento estudantil, se ja pela convivência no interior do."bloco católico". A ideolo gia nacional desenvolvimentista, especialmente aquela produzi da e difundida pelo Instituto de Estudos Superiores - ISEB, é crescentemente absorvida por parcelas do meio profissional. Assim a pröpria realidade apresenta questionamentos políticos que sensibilizam segmentos de Assistentes Sociais e se traduzem num início de revisão da prātica da instituição Serviço Social.

Com o movimento politico-militar de 1964, essas manifestações são isoladas e obrigadas a refluir, reapare cendo, apenas, nas décadas seguintes. Apesar da presença dessas tendências expressarem um dado novo de significativa importância para o desenvolvimento posterior da profissão, na busca de novas bases de legitimidade, a dimensão que assumem é restrita, aparecendo apenas como marginais e pouco definidas. Cabe considerar tambẻm que a crítica que essas correntes passam a explicitar e o contra-discurso que produzem não po- 
vem ser, ainda, caracterizados como uma ruptura com a herança conservadora do Serviço Social. Situam-se nos marcos do huma nismo e do desenvolvimentismo, não atingindo as bases da orga nização da sociedade.

0 aprofundamento desses questionamentos recupe rara 0 início dos debates que se verificou nos anos sessenta, incorporando, ao mesmo tempo, os temas presentes na literatura profissional latino-americana representativa do "Movimento de Reconceituação" do Serviço Social (69) que colocam em ques tão a perspectiva meramente modernizadora da profissão.

Se a modernização levada a efeito pela instituição se mantẻm dentro dos marcos do pensamento cosservador, representando não mais que sua atualização, torna-se necessärio qualificar o que se entende por ruptura com aquela heran ça, evitando uma perspectiva maniqueista e/ou particularista na anālise da profissão.

A ruptura com a herança conservadora expressase como uma procura, uma luta por alcançar novas bases de le gitimidade da ação profissional do Assistente Social, que

(69) A literatura profissional produzida em países como Uruguai, Chi le, Argentina e Peru é absorvida nas elaboraçōes iniciais dessa nova pers pectiva. Ver: D. Palma. La Reconceptualizacioon: Una Busqueda en América Latina. Buenos Aires, Ed. Ecro, Serie Celats, $n^{\mathbb{F}} 2$, 1975; N. Alayon et alii. Desafio al Servicio Social. Buenos Aires, Humanistas, 1975; V.P. Fa leiros. Trabaio Social: Ideologia v Método. Buenos Aires, Ed. Ecro, 1972; H. Kruse. Introdución a la Teoria Científica del Servicio Social. Buenos Aires, Ed. Acro, Serie ISI/1, 1972; N. Kisnermain. Sete Estudos sobre o Serviço Social. São Paulo, Cortez e Moraes Ed., 1978; E. Ander-Egg. E1 Servicio Social en 1a Encrucijada. Mexico, UMETS, 1971; L. Lima e R. ROdrigues "Metodologismo: Estallido de una Epoca". In: Acción Crítica, $n^{\circ} 2$, Lima, Celats/Alaets, jul. 1977; L. Lima. 'Marchas y Contramarchas del Tra bajo Social: Repasando la Reconceptualizaciōn". In: Acción Crítica, n ${ }^{\circ}$ 6, Lima, Celats/Alaets, dez. 79; B. Lima. Contribuiçảo à Metódólogia do Serviço Social. Belo Horizonte, Interlivros, 1976; J.P. Netto. "A Critica Conservadora a Reconceptualizaçãa". Serviço Social e Sociedade, n? 5 . São Paulo, Cortez Ed., ano II, mar. 1981; H.I. Junqueira. "Quase Duas Décadas de Reconceituação do Serviço Social: Umaa Abordagem Critica". Serviço Social e Sociedade, n 4, São Paulo, Cortez Ed., ano II, dez. 1980. 
reconhecendo as contradiçöes sociais presentes nas condiçöes do exercicio profissional, busca colocar-se, objetivamente, a serviço dos interesses dos usuärios, isto $\bar{e}$, dos setores domi nados da sociedade. Não se reduz a um movimento "interno" da profissão. Engloba-se num movimento social mais geral, deter minado pelo confronto e a correlação de forças entre as clas ses fundamentais da sociedade, o que não exclui a responsabi lidade da categoria pelo rumo imprimido às suas atividades $e$ pela forma de conduzi-las.

Essa ruptura, entendida numa dimensão proces sual, tem como pré-requisitos que o Assistente Social aprofun de a compreensão das implicações politicas de sua prätica pro bissional, reconhecendo-a como polarizada pela luta de classes. Em outros termos, o profissional è mobilizado na implementação de politicas sociais que trazem no seu bojo interesses divergentes e antagônicos que o exercício profissional, contraditoriamente, reproduz, tendendo a ser cooptado por uma das forças em confronto. Essa compreensão è băsica para tornar possivel, por parte do Assistente Social, uma opção teórico-prática por um projeto coletivo de sociedade, superan do as ilusões de um fazer profissional que paira "acima" da histöria. Isto implica, por sua vez, no enriquecimento do ins trumental cientïfico de anälise da realidade social e no acom panhamento atento da dinâmica conjuntural.

A interação entre o aprofundamento teórico ri goroso e a prática renovada, politicamente definida, constitui elemento decisivo para a superação das artimanhas ideoló gicas incorporadas pela profissão em sua evolução histörica: o voluntarismo, a prätica rotineira e burocratizada, as ten dências empiricistas, e alheiamento do modo de vida e o descó nhecimento do saber popular, etc.

o posicionamento crítico -- que passa a ser as sumido nos ûltimos anos por uma parcela minoritäria, embora crescente, de Assistentes Sociais -- emerge não apenas de in 
ciativas individuais, mas como resposta às exigências apre sentadas pelo momento histörico. Torna-se possível à medida que o contingente profissional se expande e sofre os embates de uma política econômica amplamente desfavorável aos setores populares. E numa conjuntura político-econômica, em que já não se pode desconhecer as manifestações populares, frente ao revigoramento dos movimentos sociais e do processo organizati vo das diversas categorias profissionais, que a prática do Assistente Social passa a ser analisada a partir das implicações políticas do papel desse intelectual vinculado a um projeto de classe. Verifica-se, aî, tentativas de ruptura de par te do meio profissional com o papel tradicionalmente assumido, na procura de somar-se às forças propulsoras de um novo.proje to de sociedade. A isso se alia a busca de fundamentos cientí ficos mais sólidos que orientem a atuação, ultrapassando a me ra atividade tēcnica. Questiona-se, inclusive, que tipo de orientação teórico-metodológica deve informar a prática e como esta pode ser repensada a serviço da produção de conheci mentos voltados para os interesses dos setores populares e de sua organização autônoma. Essa nova qualidade de preocupação com a prätica profissional está dirigida ainda a resgatar,sis tematizar e fortalecer o potencial inovador contido na vivência cotidiana dos trabalhadores, na criação de alternativas concretas de resistência ao processo de dominação.

E importante frisar que essa perspectiva se traduz, presentemente, em experiências levadas a efeito por grupos profissionais num trabalho de organização popular, de assessoria a movimentos sociais urbanos, seja través de Universidades, de organismos püblicos, de Igreja, etc. Tal se reflete na estruturação dos cursos, que orientam os currículos para uma maior incorporação das Ciências Sociais, amplian 
do a bagagem científica dos profissionais. (70) Amplia-se, ao mesmo tempo, o processo de organização da categoria pro fissional, através da criação e dinamização de suas entidades representativas que vêm marcando presença nos movimentos e no processo de organização dos trabalhadores. E, será justamente o balanço crítico rigoroso dessas experiências que permiti rä apontar reavaliações necessärias à essa prätica alternativa. (미)

A discussão do papel profissional dentro da $\underline{1 i}$. nha de ruptura com a herança conservadora do Serviço Social deve passar por duas ordens de consideração em relação ao meio profissional dos Assistentes Sociais. Se alguns de seus segmentos colocam-se na perspectiva de transformar-se em inte lectuais orgânicos do proletariado, não se tem em vista a pas sagem, em massa, da categoria dos Assistentes Sociais para

(70) Uma das experiências pioneiras, a nivel da formação profissional na linha de tentativa de ruptura da herança conservadora do Serviço Social é dada, ainda nos inícios da década de setenta, pela experiência da Escola de Serviço Social da Universidade Católica de Minas Gerais, a qual encontra-se documentada atravês dos seguintes trabalhos: L.S. Lima et alii. "A Prática como Fonte de Teoria". Escola de Serviço Social da UCMG, jum. 1971 (mimeo); L.S. Lima et alii. "A Relação Teoria-Prática no Serviço Social". In: Compendio sobre Metodologia para el Trabajo Social. Buenos Aires, Ed. Ecro, serıe ISI74, 2a. ed., 1976, p. 76-178; L.S. L1ma et alii. "Proyecto de Reestruturación de la Escuela de Trabajo Social de Ia Universidad Católica de Minas Gerais (Belo Horizonte)". In: Compendio sobre Reestruturación de la Carrera de Trabajo Social. Buenos Aîres., Ed. Ecro, sërie ISI75, 1973, p. 25-67; "Anălise Histórica da Orientação Meto dológica da Escola de Serviço Social da UCMG-BH"' (mimeo), 1974.

(71) Nesse sentido aparece de grande relevância a percepção que a populaçáo cliente forma da prätica geral dos Assistentes Sociais e, espe cialmente, das recentes iniciativas. Segundo pesquisa realizada em 1980 , pode-se verificar que a população-cliente demonstra clareza das diferentes posturas e posições de classe que informam a prätica profissional, percebendo, inclusive, as implicaçōes institucionais de seu trabalho. As sume, ao mesmo tempo, uma posição vigilante frente ao tipo de profissio nal que the $\vec{e}$ apresentado, recusando aqueles que assumem uma posição con troladora e tutelar diante do movimento popular. Ver a respeito: D. Pie $\bar{T}$ re et alii. "O Trabalho Social de Organização Popular em Instituições Pũblicas". Revista Serviç̧o Social e Sociedade n 6, ano III, São Paulo, Cor tez Ed., 1981, p. 67.98. 
assumir essas funções. Tampouco deve-se desconsiderar as rela ções da categoria -- enquanto expressão dos estratos médios com o conjunto da classe trabalhadora, no processo de constru ção de uma contra-hegemonia que tendo por centro o proletaria do, seja capaz de incluir em seu projeto para a sociedade as aspirações especificas dos setores mëdios que the são mais próximos. Nesse sentido o debate sobre o significado e a dire ção social da prätica profissional deve ser incentivado no meio dos Assistentes Sociais, alargando as bases de um exercí cio profissional que respeite e contribua para a defesa da am pliação do espaço democrätico, da participação popular no momento histórico presente. 
LITERATURA CITADA

ABESS. Valores e Serviço Social. Constribuição ao XIV Congres so Internacional de Escolas de Serviço Social (Helsink, agos to 1968). Rio de Janeiro, ABESS, 1968 .

ALAYON, N. et alii. Desafio al Servicio Social. Buenos Aires Humanitas.

ALMEIDA, A.A. "O Movimento de Reconceituação no Brasil: Pers pectivas e Consciência. Revista Debates Sociais $n^{\circ} 2$, Rio de Janeiro, CBCISS, 1975, p. 43-53.

ALTHUSSER, I. Ideologia e Aparelhos Ideológicos do Estado.São Paulo. Martins Fontes, s.d.

AMMANN, S.B. Ideologia e Desenvolvimento de Comunidade no Bra sil. São Paulo, Cortez, 1980 .

Anais do II Congresso Brasileiro de Serviço Social. Rio de Ja neiro, CBCISS, 1961.

ANDER EGG, E. El Servicio Social en la Encrucijada. México, UMETZ, 1971 .

BARBOSA LIMA, S. A Participação Social no Cotidiano. São Pau 10, Cortez \& Moraes, 1979.

BOBBIO, N. et alii. O Marxismo e o Estado. Rio de Janeiro, Graal, 1979 . 
BRANDAO, C.R. "A Prática Social e a Prätica Profissional". Pạ lestra pronunciada no Seminărio Regional de ABESS. São Paulo, 12 de maio, 1981.

BRAVERMAN, H. Trabalho e Capital Monopolista. A Degradação do Trabalho no Século XX. Rio de Janeiro, Zahar, 1977 .

BRUNEAU, T. O Catolicismo Brasileiro em Epoca de Transição, São Paulo, Loyola, 1974 .

CARDOSO, F.H. O Modelo Político Brasileiro e Outros Ensaios. São Paulo, Difel, 1973.

CARDOSO, F.H. Autoritarismo e Democratização. Rio de Janeiro, Paz e Terra, 3a. ed., 1975.

CARDOSO, F.H. ¿̇ FALETTO, E. Dependência e Desenvolvimento na Amërica Latina. Rio de Janeiro, Zahar Ed.,1973.

CARVAlHo, R. "Modernos Agentes da Justiça e da Caridade". Revista Serviço Social e Sociedade $n^{2} 2$. Ano I, mar/1980. São Paulo, Cortez Ed., p. 43-71.

COUTINHO, R. "Sobreviver para Trabalhar: Salärio e Alimentação do Trabalhador Brasileiro". Caderno do CEAS n: 48, mar/abr, 1977. Salvador, Centro da Estudos e Ação Social, p. 33-40.

DELLA CAVA, R. "Igreja e Estado no Brasil no Sëculo XX". In: Estudos CEBRAP $\mathrm{n}^{\circ} 12$, São Paulo, CEBRAP, 1975.

"Documento de Araxâ". Revista Debates Sociais $n^{\circ} 4$, ano III, Rio de Janeiro, CBCISS, mai. 1967. 
"Documento de Teresópolis - Metodologia do Serviço Social." Revista Debates Sociais. Suplemento n: 4, 5a. Ed., Rio de Janeiro, CBCISS, set. 1978.

ENGELS, F. "A Contribuição à Crítica da Economia Política de Karl Marx." In: MARX, K., e ENGELS, F. Textos. 3. São Paulo, Ed, Sociais, 1977.

ENGELS, F. Do Socialismo Utópico ao Socialismo Científico.lis. boa, Ed. Estampa, 1971.

ESCOLA DE SERVIÇO SOCIAL da Universidade Católica de Minas Ge rais. "Anālise Histórica da Orientação Metadológica da Escola de Serviço Social da UCMG - Be 1o Horizonte." out. 1974 (mimeografado).

FALEIROS, V.P..Trabajo Social: Ideologia y Método. Buenos Aires. ECRO, 1972 .

FERNANDES, F. "A Anālise Sociológica das Classes Sociais". In: Ensaios de Sociologia Geral e Aplicada.São Paulo, Pioneira, 3a. ed., 1976, cap. 2, p. 6592.

FERNANDES, F. Apontamentos Sobre a "Teoria do Autoritarismo". São Paulo, Hucitec, 1979.

FERNANDES, F. Brasil: em Compasso de Espera. Pequenos Escritos Políticos. São Paulo, Hucitec, 1980.

FERNANDES, F. Capitalismo Dependente e Classes Sociais na Amé rica Latina. Rio de Janeiro, Zahar, 3a., 1981.

FERNANDES, F. "Raça e Sociedade: O Preconceito Racial em São Paulo (Projeto de estudo)". In: A Sociologia 
numa era de Revolução Social. Rio de Janeiro, Zahar, 2a. ed., 1976, cap. IX, p. 285-313.

FERNANDES, F. A Revolução Burguesa no Brasil. Ensaio de Inter pretação Sociológica. Rio de Janeiro, Zahar, 1975 .

FORACCHI, M.M. e MARTINS, J.S. Sociologia e Sociedade (Leituras de introdução à Sociologia). Rio de Janeiro, Livros Técnicos e Científicos, 1977.

FURTADo, C. O Brasil Pós-Milagre. Rio de Janeiro, Paz e Terra, 1981 .

GERMANI, G. Política y Sociedad em una Epoca de Transición. Buenos Aires, Ed. Paidôs, 1962.

GORZ, A. (org.) Crítica da Divisão do Trabalho. São Paulo,Mar tins Fontes, 1980 .

GORZ, A. "Técnica, Técnicos e Luta de Classe" In: GORZ, A. (org.) Crítica da Divisão do Trabalho.- São Paulo, Martins Fontes, 1980 .

GRAMSCI, A. "Americanismo e Fordismo". In: Obras escolhidas. Lisboa, Estampa, 1974, p. 135-86.

GRAMSCI, A. Maquiavel, a Política e o Estado Moderno. Rio de Janeiro, Civilização Brasileira, 1978, 3a. ed.

GRAMSCI, A. Os Intelectuais e a Organizaçäo da Cultura.- Rio de Janeiro, Civilização Brasileira, 1979, 3a. ed. 
GRAMSCI, A. "Problemas da Vida Cultural". In: Obras escolhidas. (2 v.), Lisboa, Estampa, 1974, p. 184-214.

GUILHON DE ALBUQUeRQUe, J.A. A Metäfora da Desordem, Rio de Janeiro, Paz e Terra, 1977.

HAGEN, E.E. On the Theory of Social Change. Homewood, Dorsey Press, 1962.

HELlER, A. O Quotidiano e a História. Rio de Janeiro, Ed. Paz e Terra, 1972 .

IAMAMOTO, M.V. e MANRIQUE, M.C. "Hacia el Estudio de la História del Trabajo Social en Amêrica : Latina". Acciön Crítica, $\mathrm{n}^{\circ}$ 5, abr. 1979, Lima, CELATS/ ALAETS, p. 53-73.

IANNI, 0. O Colapso do Populismo no Brasil. Rio de Janeiro, Civilização Brasileira, 1968 .

IANNI, 0. Estado e Planejamento Econômico no Brasil. 1970). Rio de Janeiro, Civilização Brasileira, 1979 .

IANNI, 0. Pronunciamento, como Membro da Banca Examinadora da Tese de Mestrado de Maria Luiza de Souza, PUC-SP, 18 de agosto de 1978.

IANNI, 0. Sociologia da Sociologia Latino-Americana. Rio de Janeiro, Ed. Civilização Brasileira, 1971.

JUNQUEIRA, H. I. "Quase duas Décadas de Reconceituação do Ser viço Social: Uma Abordagem Crítica:" Serviço. Social e Sociedade, $n^{9} 4$, São Paulo, Cortez, ano III, dez. 1980 . 
KISNERMAN, N. Sete Estudos sobre Serviço Social. São Paulo, Cortez \& Moraes, 1978.

KOWARICK, L. "Proceso de Desarrollo del Estado en Amërica Latina y Políticas Sociales." Acción Crítica, $\mathrm{n}^{\text {? }}$ 5, Lima CELATS/ALAETS, abr. 1979, p. 6-13.

KRUSE, H. Introducción a la teoria científica del Servicio So cial. Buenos Aires, ECRO, sêrie ISI/1, 1972

LEFEBVRE. H. Critique de 1 a vie quotidienne. ( 2 v.). Paris, L" Arche, 1958-1961.

LEFEBVRE, H. De 10 Rural a 10 Urbano. Barcelona, Ed. Penínsu$1 \mathrm{a}, 1974$.

LEFEBVRE, H. "Estrutura Social: A Reprodução das Relações Sociais." In: FORRACCHI, M.M. e MARTINS, J.S. 1977. Sociologia e Sociedade (Leituras de Introdução à Sociologia). Rio de Janeiro, Livros Têcnicos e Científicos, Ed. 1977.

LEFEBVRE, H. La Vida Cottidiana en el Mundo Moderno. Madri, Alianza, 1972 .

LEFEBVRE, H. Sociologia de Marx. São Paulo, Forense, 1968.

LENIN, V.I. O Estado e a Revolução: O Conceito Marxista do Po. der. Rio de Janeiro, Diálogo Livraria, s.d.

LERNER, D. The Passing of Traditional Society: Modernizing the Middle East. New York, The Free Press,1958.

LIMA, A.A. "A Fundação das Duas Primeiras Escolas de Serviço Social no Brasil". Dissertação de Mestrado apre 
sentada à Escola de Serviço Social da PUC-RJ. Rio de Janeiro, 1977 (mimeografado).

LIMA, B. Contribuição à Metodologia do Serviço Socia1. Belo Horizonte. Interlivros, 1976.

LIMA, L.S. "Marchas e Contramarchas de1 Trabajo Social: Repasando la Reconceptualización." Acción Crítica. $\mathrm{n}^{\circ}$ 6, Lima, CELATS/ALAETS, dez. 1979, p. 25.31.

LIMA, L.S. et alii. "Prâtica como fonte de teoria." Escola de Serviço Social da UCMG, jun. 1971 (mimeografado).

LIMA, L.S. et alii. "Proyecto deReestruturación de la Escuela de Servicio Social de la Universidade Católica de Minas Gerais (Belo Horizonte)." In: Compen-. "dio sobre: Reestruturación de la Carrera de Trabajo Social. Buenos Aires, ECRO, série ISI/5, 1973.

LIMA, L.S. et alii. "A Relação Teoria-Prática no Serviço Social." In: Compendio sobre Metodologia para e1 Trabajo Social. Buenos Aires, ECRO, série ISI/ 4, 2a. ed., 1976 .

LIMA, L.S. e RODRIGUES, R. "Metodologismo: Estallido de una Epoca." Acción Crítica, $n^{\circ} 2$, Lima CELATS/. ALAETS, ju1. 1977 .

MACCIOCCHI, M.A. A Favor de Gramsci. Rio de Janeiro, Paz e Terra, 2a. ed., 1980 .

MAGUiNA, A. "Dessarrollo Capitalista y Trabajo Social. Peru,18961979. Lima, CELATS, 1979. 
MAGUINA, A. "Trabajo Social: Servicio o Actividad Produtiva?" Acción Crítica, $\mathrm{n}^{\circ}$ 3, Lima, CELATS/ALAETS, 1977, p. $17-26$.

MALlOY, J. "Previdência Social e Distribuição de Renda. Notas de Pesquisa" In: Estudos CEBRAP, n: 25 , Petröpolis, Vozes, S/d. p. 113-34.

MALLOY, J. "Política de Bem-Estar Social no Brasil: Histórico Conceitos e Problemas". In: Revista de Adminis. tração Püblica, $n^{\circ} 10$, ano 2, Rio de Janeiro, junho de 1976 , p. 5-29.

MALLOY, J. "A Política de Previdência Social no Brasil: Partí cipação e Paternalismo". In: Dados n 13, Rio de Janeiro, IUPERG, 1976, p. 93-115.

MANNHEIN, K. Ensayos de Sociología y Psicología Social. México, Fondo de Cultura Econômica, 1963.

MANNHEIN, K. Ideologia e Utopia. Rio de Janeiro, Zahar, 3a. ed., 1976.

MANNHEIN, K. Sociologia Sistemática. São Paulo, Pioneira, 1971. 2a. ed.

MÃNTEGA, G. e M. MORAIS. "Tendências Recentes do Capitalismo Brasileiro". In: Contraponto $n^{\circ} 3$, ano III, Rio de Janeiro, Centro de Estudos Noel Nutells, set. 1978 , p. 59-67.

MARSHALl, T.H. Cidadania, Classe Social e "Status", Rio de Janeiro, Zahar, 1967. 
MARTINS, J.S. Pronunciamento efetuado durante o Curso de So ciologia da Vida Cotidiana para Alunos de Gra duação em Ciências Sociais da Universidade de São Paulo, em 11.03.75 (Anotação de aula).

MARTINS, J.S. Capitalismo e Tradicionalismo. Estudos sobre as Contradições da Sociedade Agräria no Brasil. São Paulo, Pioneira, 1975.

MARTINS, J.S. O Cativeiro da Terra. São Paulo, LIvraria Ed. Ciências Sociais Humanas, 1979.

MARTINS, J.S. A Imigração e Crise do Brasil Agrärio. São Paulo, Pioneira, 1973.

MARTINS, J.S. "As Relações de Classe e a Produção Ideológica da Noção de Trabalho." Revista Contexto, n? 5, São Paulo, Hucitec, mai. 1978, p. 37-53.

MARTINS, J.S. Sobre o Modo Capitalista de Pensar. São Paulo, Hucitec, Coleção Ciências Sociais, 1978.

MARX, K. El Capital. Crítica de la Economía Política. México, Fondo de Cultura Económica, 2a. ed., 5a. reimpressão, 1975,3 t.

MARX, K. O Capital. Crítica da Economia Política. 3a. ed.,Rio de Janeiro, Civilização Brasileira, 1975.

MARX, K. E1 Capital. Libro I, Capítulo XI - (Inédito). Buenos Aires, Sig1o XXI, 1973.

MARX, K. "Introdução Geral à Crítica da Economia Política". In: MARX, K. e SWEEZY, P. Para uma Crítica da Economia Politica. Porto, Publicações Escorpião, Cadernos 0 Homem e a Sociedade, 1973. 
MARX, K. La Miseria de la Filosofia. Buenos Aires, Siglo XXI, 3a. ed., 1974 .

MARX, K. Los Fundamentos de la Crítica e la Economia Politica, Madri, Comunicación, 1972, 2 t.

MARX, K. "Manuscritos Econömico-Filosöficos de 1848." In: MARX, K. e ENGELS, F. Manuscritos Econômicos. Vărios. Barcelona, Grijalbo, 1975.

MARX, K. "O Dezoito Brumārio de Luís Bonaparte." In: MARX K. e ENGELS, F. Textos 3, São Paulo, Ed. Sociais, 1977 .

MARX, K. "Prefäcio à Contribuição à Crítica da Economia Polí tica". In: MARX, K. e ENGELS, F. Textos 3. São : Paulo, Ed. Sociais, 1977.

MARX, K. "Trabalho Assalariado e Capital". In: MARX, K. e ENGELS, F. Textos 3, São Paulo, Ed. Sociais, 1977 .

MARX, K. e ENGELS,.. F. Textos 3, São Paulo, Ed. Sociais, 1977.

MARX, K. e ENGELS, F. A Ideologia Alemã (Feuerbach). São Pau 1o, Grijalbo, 1977.

MELlO, J.M.C. e L.G. DE MELlO Belluzzo. "Reflexões entre a Crise Atual" Escrita Ensaio $n^{\circ}$ 2, ano I, 1977, p. 16-27.

MTLLIBAND, R. El Estado en la Sociedad Capitalista. Rio de Ja neiro, Paz e Terra, 1977.

MILlS, W. A Nova Classe Média. Rio de Janeiro, Zahar, 1969. 
NETTO, J.P. "A Crítica Conservadora à Reconceptualização." Re vista Serviço Social e Sociedade $n^{\circ}$,

São Paulo, Cortez, ano II, mar. 1981.

NISBET, R. La Formación del Pensamiento Sociológico. Buenos Aires, Amorrortu, vol. I, 1969.

NISBET, R. "Conservadorismo e Sociologia" In: MARTINS, J.S. Introdução Crîtica à Sociologia Rural. São Pau lo, Hucitec, 1980 .

O'CONNORS, J. USA: A Crise do Estado Capitalista. Rio de Janeiro, Paz e Terra, 1977.

PALMA, D. La Reconceptualizaciōn: Una Büsqueda en América Latina. Buenos Aires, ECRO, Sërie CELATS $n^{\circ} 2$, . 1970 .

PARODI, J. "El Significado del Trabajo Social en el Capitalís mo y la Reconceptualización." Acción Crítica, $\mathrm{n}^{8}$ 4, Lima, CELATS/ALAETS, 1978, p. 33-43.

PIERRE, D. et alii. "O Trabalho Social de Organização Popular em Instituições Públicas." Revista Serviço Social e Sociedade, $\mathrm{n}^{\circ} 6$, ano III. São Paulo, Cortez Ec., set. 1981, p. 67-98.

PIGNON, D. e QUERZOLA, J. "Ditadura e Democracia na Produção". In: GORZ, A. (org) Crítica da Divisão do Traba. 1ho. São Paulo, Martins Fontes, 1980.

PINHEIRO MACHADO, L. "Alcances e Limites da Teoria da Modernização". Revista Administração de Empresas, Vol. 10, $n^{\circ} 2$, Fundação Getülio Vargas, julset. 1970, p. 169-192. 
PIOTTE, J.M. El Pensamiento de Gramsci. Barcelona, A. Redondo: Ed. 1972 .

PORTELl, H. Gramsci e o Bloco Histórico. Rio de Janeiro, Paz e Terra, 1977 .

PoUlantzas, N. Poder Politico e Classes Sociais. São Paulo, Martins Fontes, 1977.

POUlantzas, N. O Estado em Crise. Rio de Janeiro, Graal, 1977.

QUEDA, 0. e DUARTE, J.C. "Agricultura e Acumulação." Debate e Crítica, $n^{\circ} 2$, jan-jun., São Paulo, Hụcitec, 1974, p. $90-7$.

QUEDA. 0, et alii. Evolução Recente das Culturas de Arroz e Feijão no Brasil, Brasília, BINAGRI, Biblioteca Nacional de Agricultura, 1979.

RIZZOLI, A. Assistencialismo e Marginalidade: O Serviço de Co locação Familiar em São Carlos. Piracicaba,Dis sertação de Mestrado ESALQ/USP, 1978.

RODRIGUES, J.A. Sindicato e Desenvolvimento no Brasil. São Paulo, Difel, 1968.

SINGER, P. A Crise do Milagre. Interpretação Crítica da Economia Brasileira. Rio de Janeiro, Paz e Terra, 3a. ed., 1977 .

SINGER, P. et alii. São Paulo: 1975. Crescimento e Pobreza. São Paulo, Loyola, 1976.

SINGER, P. e V.C. BRANDT. São Paulo: O Povo em Movimento. Petröpolis, Vozes/CRBRAP, 1980. 
VIANNA, L.W. Liberalismo e Sindicato no Brasil. Rio de Janeiro, Paz e Terra, 1976.

VILlAÇA, A.C. O Pensamento Católico no Brasil. Rio de Janeiro, Zahar, 1975.

VERDES-LEROUX, J. Le Travait Social. Paris, Les Editions de Minuit, 1978 .

WEFFORT, F. et alii. "A Crise Politica e Institucional". In: Revista de Cultura Contemporânea, $n^{\circ} 2$, ano $I$, São Paulo, CEDEC, jan. 1979, p. 47-61.

YASBECK, M.D. Estudo da Evolução Histórica da Escola de Servi ço Social de São Paulo no período de 1936-1945. Dissertação de Mestrado apresentada à PUC-SP. São Paulo, 1977 (mimeografado). 